\title{
ANÁLISE DAS UNIDADES DE CONSERVAÇÃO FEDERAIS DO ESTADO DE MATO GROSSO
}

\author{
NELY TOCANTINS \\ Bióloga
}

Orientador: Prof. Dr. ALVARO FERNANDO DE ALMEIDA

Dissertação apresentada à Escola Superior de Agricultura "Luiz de Queiroz", Universidade de São Paulo, para obtenção do título de Mestre em Ciências, Area de Concentração: Ciências Florestais.

P I R A C I C A B A

Estado de São Paulo - Brasil

Novembro - 1997 
Dados Internacionais de Catalogação na Publicacão (CIP) DIVISÃo DE BIBLIOTECA E DOCUMENTAÇÃO - Campus "Luiz de Queiroz"/USP

Tocantins, Nely

Análise das unidades de conservação federais do Estado de Mato Grosso / Nely Tocantins. - Piracicaba, 1997

199 p. : il.

Dissertaçāo (mestrado) - E Escola Superior de Agricultura Luiz de Queiroz, 1998 Bibliografia.

1. Área de conservação 2. Estação ecológica 3. Mato Grosso 4. Parque Nacional I.Título 


\section{ANÁLISE DAS UNIDADES DE CONSERVAÇĀO FEDERAIS DO ESTADO DE MATO GROSSO}

\section{NELY TOCANTINS}

Aprovada em: 20/01/98

Comissão Julgadora:

Prof. Dr. Alvaro Fernando de Almeida ESALQ/USP

Prof. Dr. Paulo Nogueira Neto IB/USP

Prof. Dr a . Maria Inez Pagani UNESP/Rio Claro

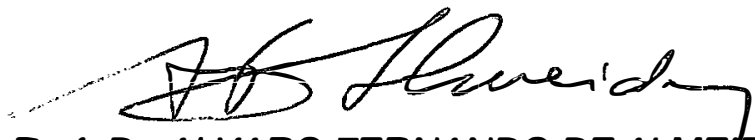

Prof. Dr. ALVARO FERNANDO DE ALMEIDA

Orientador 
Á primeira grande conservacionista que conheci (minha mãe)

e ao grande contador de histórias do "sertão" do Mato Grosso (meu pai) (In memorian).

Ao meu companheiro de todas as horas, Joaquim e ao meu filho Thiago.

\section{DEDICO}

Aos grandes e incógnitos batalhadores, que trabalham nas Unidades

e pelas Unidades de Conservação do Estado de Mato Grosso.

\section{OFEREÇO}




\section{AGRADECIMENTOS}

Ao Prof. Dr. Alvaro Femando de Almeida, pela orientação, apoio, amizade e por acreditar em mim e no meu trabalho.

Ao Prof. Dr. Mohamed Habib, da UNICAMP, pelo apoio e incentivo nessa etapa de minha vida.

A ESALQ, pela oportunidade de desenvolver meu trabalho; à CAPES, pelo apoio financeiro; à UFMT e em especial ao Departamento de Biologia ICEN/CUR pela minha liberação para a capacitação.

Ao IBAMA, pela oportunidade e apoio logístico, sem o qual não teria conseguido realizar parte de meu trabalho e em especial ao NUC/SUPES/MT e aos funcionários das Unidades de Conservação, pela acolhida e amizade a mim dispensadas.

A Coordenação, aos professores, funcionários das secretarias de graduação e pós-graduação, telefonistas e bibliotecários das Ciências Florestais e da Biblioteca Central da ESALQ/USP.

Aos amigos e colegas da turma de Pós-Graduação em Ciências Florestais, em especial à Marli, Cristina, Samir, Erika, Lauriene, Renata Cristina, Renata Batista, Elisa e Kátia, pelo carinho recebido e pela amizade que transpôs os muros da Universidade, e à Denise Alves Machado pelas primeiras informações, quando tudo era muito novo...

Aos colegas da UFMT (Professora Vera Lúcia Guarim e Professor Dalci Miranda de Oliveira), a Veterinária Cristine Strusmman e da FEMA, que de forma direta ou indireta me auxiliaram no levantamento do material bibliográfico (aliás, tarefa que sozinha não teria sido nada fácil).

Aos professores Antonio Natal, Marcos Sorrentino e Teresa Magro, pelas sugestões durante a qualificação e também fora dela.

Ao Edson, que me ensinou os primeiros comandos do computador è̀ Silvia que "me deu uma mão" (digo, as duas) nas etapas finais desse trabalho.

Às ONG's: IPECA, OPAN, ARCA e ECOTRÓPICA que prontamente atenderam às minhas indagações, colocando seu material à disposição. 
A todos que me apoiaram, e direta ou indiretamente colaboraram durante a realização deste trabalho, e que tenham sido esquecidos nos agradecimentos acima. 


\section{SUMÁRIO}

\section{Página}

Lista de Figuras

xiii

Lista de Tabelas

$x v i$

Resumo

xvii

Summary

xix

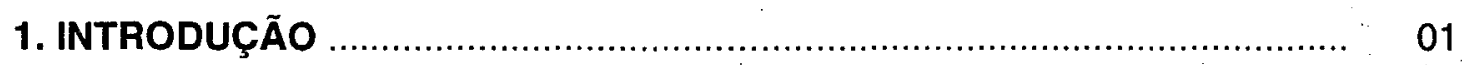

2. REVISÃO BIBLIOGRÁFICA …........................................................... 03

2.1. Fragmentação Florestal........................................................................ 03

2.2. Unidade de Conservação ................................................................... 09

2.3. Sistema Nacional de Unidade de Conservação ........................................ 12

2.4. Projeto de Lei o 2.892 de 1992 - Das categorias de Unidades de

Conservação 15

2.5. Planejamento de Unidades de Conservação ............................................ 20

2.5.1. Plano de Manejo............................................................................ 20

2.5.2. Plano de Ação Emergencial ............................................................ 21

2.5.3. Plano Operativo Anual......................................................................... 22

2.5.4. Intervenção na Zona de Entorno ......................................................... 22

2.5. Categorias de Unidades de Conservação do Estado.................................. 22

3. MATERIAL E MÉTODOS .................................................................... 25

3.1. Caracterização Geral da Área ................................................................ 25

3.2. Proposta de Trabalho ............................................................................. 25

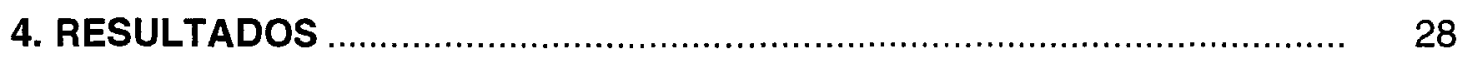

4.I. ESTAÇÃO ECOLÓGICA IQUÊ-JURUENA ............................................. 28

4.I.1. Situação Histórica e Geográfica ............................................................. 28

4.I.1.1. Localização e Limites Atuais .......................................................... 28

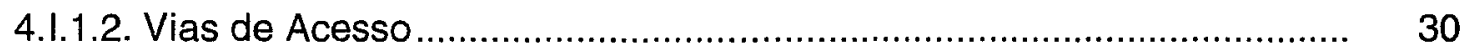

4.I.1.3. Histórico da Unidade de Conservação e Antecedentes Legais ....... 30

4.1.2. Características Biofísicas da Estação ...................................................... 31 .

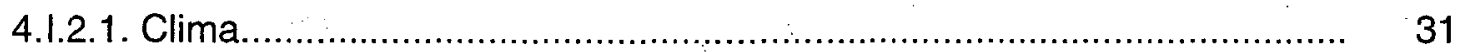

4.1.2.2. Geologia e Geomorfologia........................................................ 31

4.1.2.3. Hidrografia ............................................................................ 32

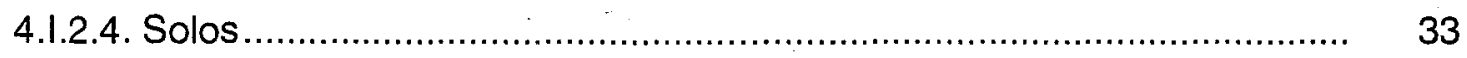

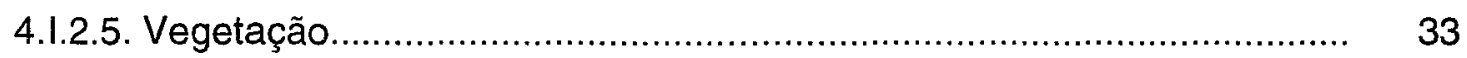

4.I.2.5.1. Região de Savana (Cerrado) .......................................................... 33

4.I.2.5.2. Floresta Estacional Sub-Montana ................................................. 33 
4.I.2.5.3. Contato Savana / Floresta Estacional ........................................ 34

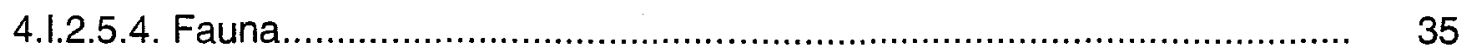

4.I.3. Características Sócio-Econômico e Culturais ........................................ 37

4.I.3.1. Situação Fundiária .................................................................... 37

4.I.3.2. Uso da Estação Ecológica............................................................. 37

4.I.3.3. Histórico de Ocupação da Região ................................................. 40

4.I.3.3.1. Dados Culturais Enauenê-Nauê.................................................. 43

4.I.3.3.2. Definição Territorial ............................................................... 45

4.I.3.4. Aspectos Culturais................................................................... 47

4.I.4. Área de Influência da ESEC ........................................................ 48

4.I.4.1. O Município de Juína.................................................................. 49

4.I.5. Aspectos Institucionais ................................................................ 50

4.I.5.1. Infra-Estrutura .......................................................................... 50

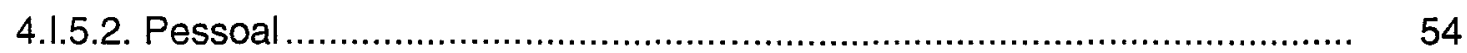

4.I.6 Considerações ............................................................................ 54

4.II. ESTAÇÃO ECOLÓGICA SERRA DAS ARARAS ............................... 56

4.Il.1. Situação Histórica e Geográfica ........................................................ 56

4.II.1.1. Localização e Limites Atuais ......................................................... 56

4.II.1.2. Vias de Acesso ......................................................................... 58

4.II.1.3. Histórico da Unidade de Conservação e Antecedentes Legais ........... 58

4.II.2. Características Biofísicas da Estação .......................................... 59

4.II.2.1. Clima .................................................................................. 59

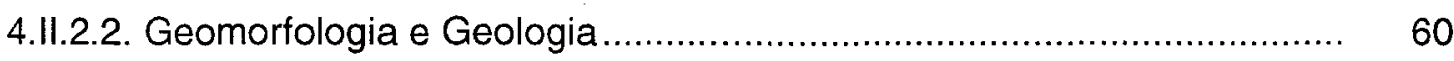

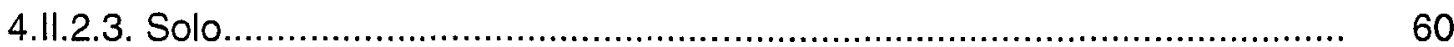

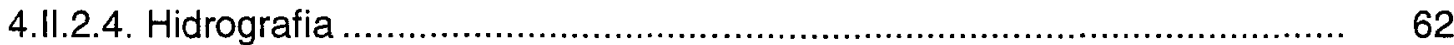

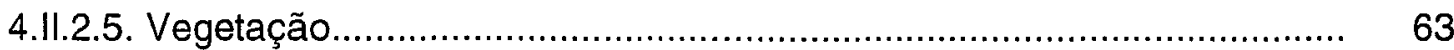

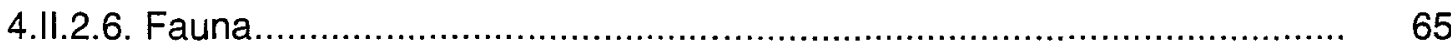

4.II.2.6.1. Habitats e as Aves............................................................ 65

4.II.3. Ocorrência de fenômenos naturais e suas conseqüências.................... 68

4.II.4. Características Sócio Econômica e Culturais......................................... 69

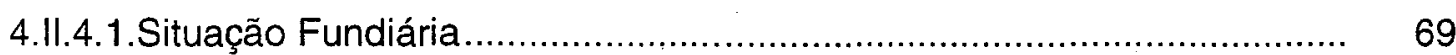

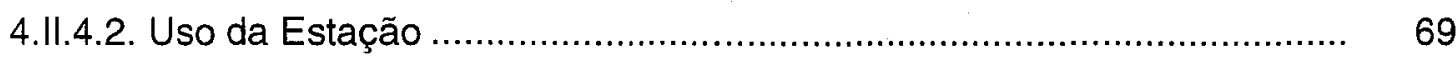

4.II.4.3. Histórico de Ocupação da Região ............................................... 70

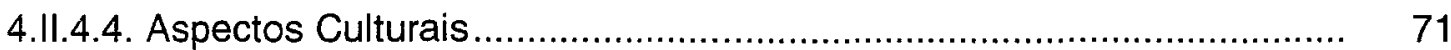

4.II.5. Área de Influência da Estação ..................................................... 71 
4.II.5.1. Faixa do Entorno ................................................................ 71

4.II.5.2. Cidade de Porto Estrela.............................................................. 72

4.II.5.3. Cidade de Barra do Bugres ....................................................... 72

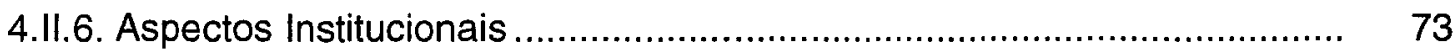

4.II.6.1. Infra-Estrutura ............................................................... 73

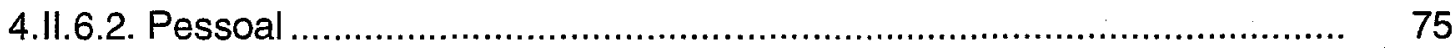

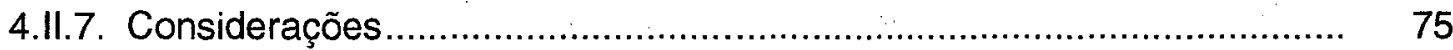

4.III. PARQUE NACIONAL DA CHAPADA DOS GUIMARÃES ..................... 77

4.III.1. Situação Histórica e Geográfica ................................................... 77

4.III.1.1. Localização e Limites Atuais ...................................................... 77

4.III.1.2. Vias de Acesso ...................................................................... 77

4.III.1.3. Histórico e Antecedentes Legais ................................................ 79

4.III.2. Características Biofísicas da Unidade de Conservação........................ 81

4.III.2.1. Clima.................................................................................... 81

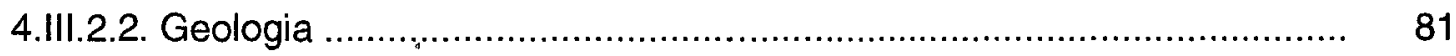

4.III.2.2.1. Grupo Cuiabá............................................................... 82

4.III.2.2.2. Grupo Paraná ..................................................................... $\quad 82$

4.III.2.2.3. Formação Botucatu ......................................................... 82

4.III.2.2.4. Formação Bauru ............................................................... 82

4.III.2.3. Geomorfologia .................................................................... 83

4.III.2.4. Hidrografia ....................................................................... 85

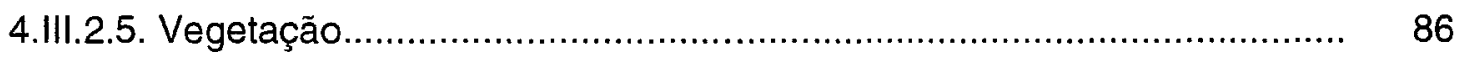

4.III.2.5.1. Mata Semidecídua................................................................ 86

4.III.2.5.2. Savana Arbórea Densa (Cerradão) ......................................... 87

4.III.2.5.3. Savana Arbórea Aberta (Cerrado) ............................................. 88

4.III.2.5.4. Savana Gramíneo Lenhosa (Campo Sujo).................................... 88

4.III.2.5.5. Savana Parque (Campo Cerrado) .......................................... 88

4.III.2.5.6. Campo Cerrado Rupestre.................................................. 89

4.III.2.6. Fauna ................................................................................ 89

4.III.3. Ocorrência de fenômenos naturais e suas conseqüências.................... 90

4.III.4. Características Sócio Econômicas e Culturais da UC.......................... 91

4.III.4.1.Situação Fundiária.................................................................... 91

4.III.4.2. Uso do Parna ............................................................................. 94

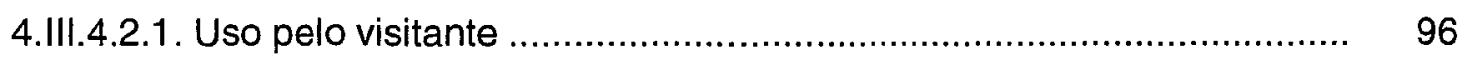

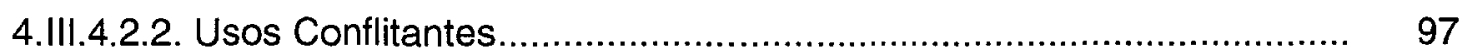




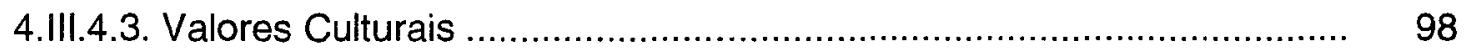

4.III.5. Área de Influência da UC............................................................... 99

4.III.5.1. O Município da Chapada dos Guimarães......................................... 99

4.III.5.2. Município de Cuiabá ................................................................. 100

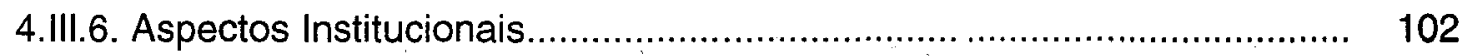

4.III.6.1. Infra-Estrutura ................................................................. 102

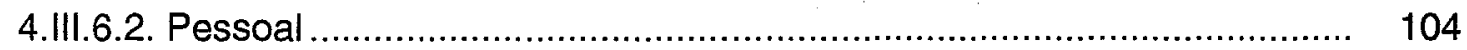

4.III.7. Considerações............................................................................ 104

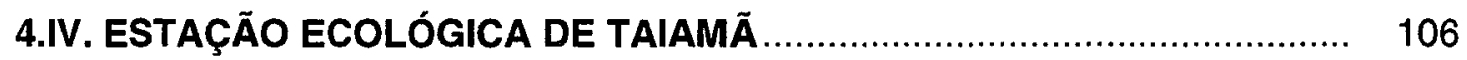

4.IV.1. Situação Histórica e Geográfica......................................................... 106

4.IV.1.1. Localização e Limites Atuais......................................................... 106

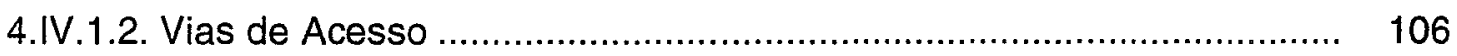

4.IV.1.3. Histórico da Unidade de Conservação e Antecedentes Legais......... 108

4.IV.2. Características Biofísicas da Região ................................................ $\quad 110$

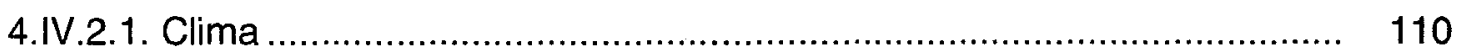

4.IV.2.2. Geologia ............................................................................ 110

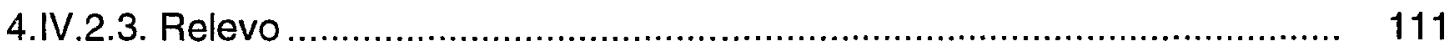

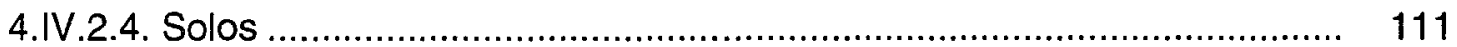

4.IV.2.5. Hidrografia

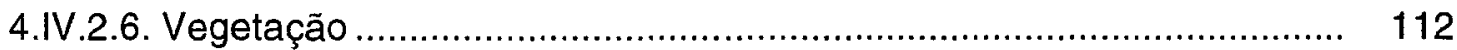

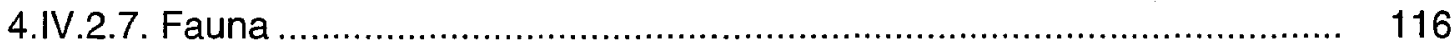

4.IV.3. Ocorrência de fenômenos naturais ..................................................... 117

4.IV.4. Características Sócio Econômicas e Culturais .................................... 117

4.IV.4.1.Situação Fundiária .......................................................................... 117

4.IV.4.2. Uso da Estação ..................................................................... 118

4.IV.4.3. Histórico da ocupação do pantanal e região....................................... 119

4.IV.4.4. Aspectos Culturais ............................................................... 122

4.IV.5. Área de Influência da Unidade de Conservação................................... 123

4.IV.5.1. Área de Entorno .......................................................................... 123

4.IV.5.2. Cidade de Cáceres...................................................................... 123

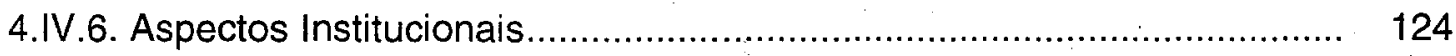

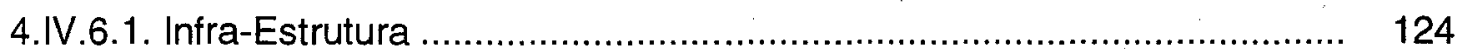

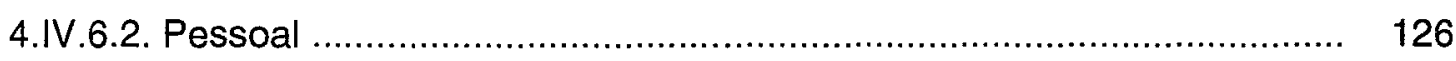

4.IV.7. Considerações ............................................................................ 126

4.V. PARQUE NACIONAL DO PANTANAL MATOGROSSENSE ................... 127 
4.V.1. Situação Histórica e Geográfica............................................. 127

4.V.1.1. Localização e Limites.............................................................. 127

4.V.1.2. Vias de Acesso ................................................................... 129

4.V.1.3. Histórico da Unidade de Conservação e Antecedentes Legais ........... 129

4.V.2. Características Biofísicas da Unidade .............................................. 130

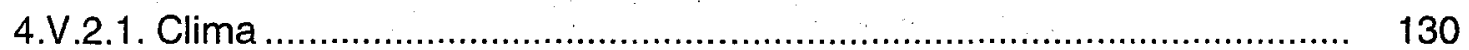

4.V.2.2. Geomorfologia................................................................... 130

4.V.2.3. Solo .............................................................................. 132

4.V.2.4. Hidrografia........................................................................... 132

4.V.2.5. Vegetação ............................................................................. 136

4.V.2.5.1. Savana Gramímeo-Lenhosa sem Floresta de Galeria.................... 136

4.V.2.5.2. Floresta Semidecidual Aluvial ................................................. 137

4.V.2.5.3. Floresta Semidecidual das Terras Baixas................................. 137

4.V.2.6. Fauna ................................................................................ 139

4.V.3. Ocorrência de fenômenos naturais e suas conseqüências .................... 141

4.V.4. Características Sócio Econômicas e Culturais ................................... 142

4.V.4.1.Situação Fundiária .............................................................. 142

4. V.4.2. Uso do Parna ........................................................................... 144

4.V.4.3. Histórico de ocupação da Região ............................................... 147

4.V.4.4. Aspectos Culturais ................................................................ 147

4.V.5. Área de Influência do Parque Nacional............................................ 148

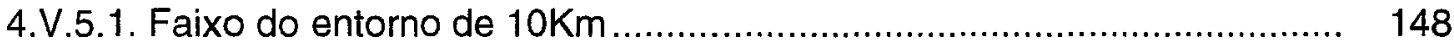

4.V.5.2. Cidades de Poconé e Corumbá ................................................. 149

4.V.5.3. Águas à montante do Parque Nacional ...................................... 151

4.V.6. Aspectos Institucionais............................................................. 152

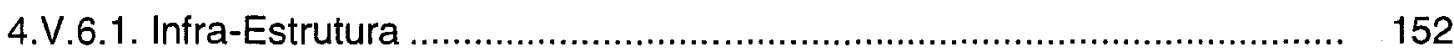

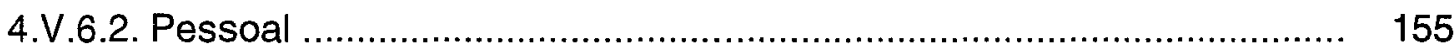

4.V.7. Considerações ........................................................................ 156

4.V.8. Síntese sobre a criação das Unidades de Conservação do Estado de Mato Grosso ..................................................................................... 157

4.V.9. Breves Considerações acerca das Áreas Indígenas .......................... 162

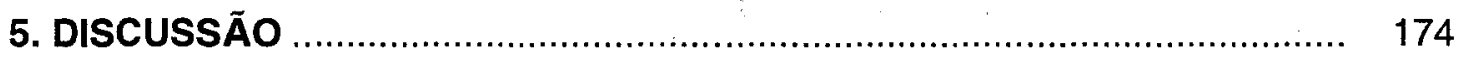

5.1. Situação Histórica e Geográfica das Unidades de Conservação............... 174

5.2. Características Sócio-Econômicas e Culturais .................................... 177

5.2.2. Questão de sobreposição de UC em terras indígenas.......................... 178 


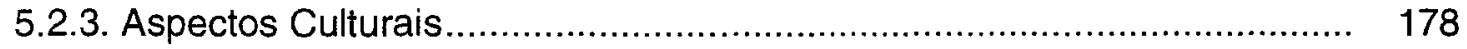

5.2.4. Zona de Entorno............................................................................ 179

5.2.5. Aspectos Sócio Econômicos e Culturais ........................................... 180

5.2.6. Instrumentos de Manejo e Gerenciamento das UC's .......................... 181

5.2.6.1. Plano de Ação Emergencial ...................................................... 181

5.2.6.2. Plano de Manejo................................................................ 182

5.2.6.3. Plano Operativo Anual (POA) ................................................ 183

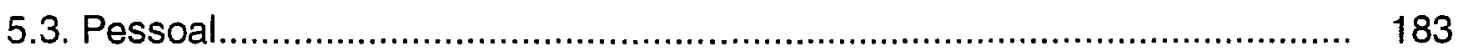

6. Participação popular na criação das Unidades........................................ 184

7. Congelamento na criação de novas Unidades....................................... 184

6. CONSIDERAÇÕES FINAIS ..................................................... 187

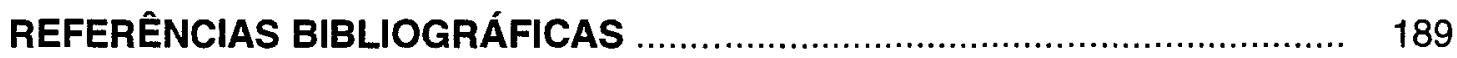




\section{LISTA DE FIGURAS}

Página

Figura 01: Representação da fração de borda $e$ interior de fragmentos florestais de diferentes formas (circular $e$ alongada) e tamanhos (pequeno, médio e grande) baseado em Forman e Godron citado por Viana, 1990

Figura 02: Representação esquemática da extinção "Vortex" (Foose, 1992)

Figura 03: Modelo de análise de viabilidade de populaçăo AVP, mostrando os efeitos de várias ameaças que contribuem na extinção e retenção da variabilidade genética (Foose, 1992)

Figura 04: Interação entre populações fragmentadas resultando em metapopulações (Foose, 1992).

Figura 05: Áreas potenciais para Conservação e Unidades de Conservação Decretadas.

Figura 06: Vista aérea da sede e campo de pouso da Estação

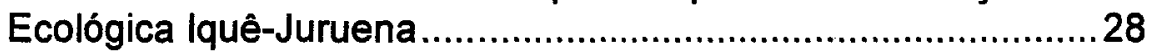

Figura 07: Mapa de Localização - Estação Ecológica lquê-Juruena ...........29

Figura 08: Aspecto da "reboleira", junto à rodovia AR-1 ..............................34

Figura 09: Aspecto da vegetação próxima aos "Três Morros" ...................... 36

Figura 10: Toca de tatú-canastra à beira da rodovia AR-1 ..........................36

Figura 11: Garimpo limitrofe à Estação, no Rio 21 de Abril, Rodovia AR-1

Figura 12: Aspecto geral do garimpo próximo à Estação 38

Figura 13: Desmatamento causado pela entrada de máquinas para a retirada de cascalho na trilha próxima aos "Três Morros".

Figura 14: Local de retirada do cascalho na cota de maior altitude, final da trilha dos "Très Morros".

Figura 15: "Bigode" que adentra a Estação, realizado na Rodovia MT319 .

Figura 16: Dente de mastodonte encontrado enterrado a $6 \mathrm{~m}$ de profundidade com aproximadamente $20 \mathrm{~cm}$ de altura por 10 de largura

Figura 17: Aspecto do entorno da Estação (ao fundo), com ocupação agropecuária

Figura 18: Aspecto da sede da Estação Ecológica 
Figura 19: Construção também conhecida por "hotel", desocupada ...........51

Figura 20: Casa do Chefe da Estaçăo Ecológica .....................................52

Figura 21: Casa dos zeladores, ambas desocupadas..............................52

Figura 22: Aspecto do posto de fiscalização ao norte da Estação, abandonado ........................................................................... 53

Figura 23: Aspecto geral da sede da Estação Ecológica Serra das

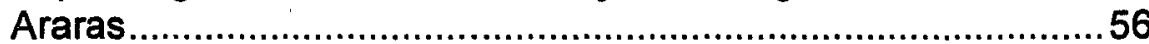

Figura 24: Mapa de Localização-Estação Ecológica Serra das Araras .......57

Figura 25: Aspecto do vale da "Saloba", próximo à Sede ..........................61

Figura26: Vista do Rio Saloba, ao lado do caminho para a sede................62

Figura 27: Aspecto de uma área recém-desmatada para a gropecuária no entorno da Estação (ao fundo)...........................71

Figura 28: Vista da sede da Estação Ecológica Serra das Araras ...............73

Figura 29: Aspecto de uma das casas de funcionário junto à sede da EE Serra das Araras..............................................................74

Figura 30: Vista do posto "Três Ribeirões", no extremo norte da

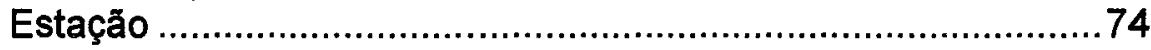

Figura 31: Uma das vistas do PARNA da Chapada dos Guimarães ...........77

Figura 32: Mapa de localização do Parque Nacional da Chapada dos

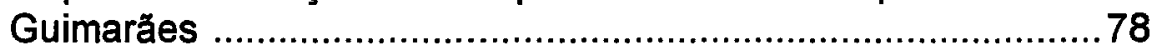

Figura 33: Restaurante Véu de Noiva no PARNA da Chapada dos

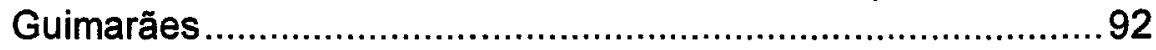

Figura 34: Vista das proximidades do Rio Mutuca ...................................93

Figura 35: Situação Fundiária do PARNA da Chapada dos Guimarães............................................................................95

Figura 36: Aspecto de uma das inúmeras formações rochosas do PARNA 99

Figura 37: Aspecto da sede atual do Parque Nacional da Chapada

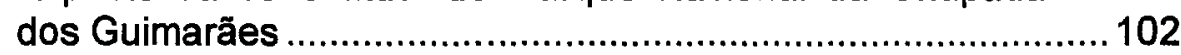

Figura 38: Vista geral da sede da Fazenda Pombal................................103

Figura 39: Aspecto da sede e parte do campo de pouso da Estação Ecológica de Taiamã .............................................................106

Figura 40: Mapa de localização da Estação Ecológica Taiamã ...................107

Figura 41: Ave "talha-mar", origem do nome da Estação Ecológica............110

Figura 42: Plantas aquáticas que margeiam as ilhas de Taiamã e Sararé.

Figura 43: Vista da Fazenda Descalvado, às margens do rio Paraguai ......120 
Figura 44: Aspectos da Estação e seu entorno...........................................123

Figura 45: Aspectos da sede e alojamentos da EE Taiamã .......................124

Figura 46: Vista geral das casas dos funcionários da Estação .................... 125

Figura 47: Aspecto do Posto Castelo de Areia, atualmente abandonado ..................................................................... 125

Figura 48: Vista geral da sede do Parque Nacional, à beira do "Rio São Lourenço"...............................................................127

Figura 49: Mapa de localização do Parque Nacional do Pantanal

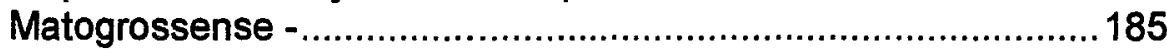

Figura 50: Vista da Serra do Amolar, ao fundo a Fazenda Acurizal, lindeira ao Parque .............................................................131

Figura 51: Mapa da bacia do Alto Paraguai e Pantanais Matogrossenses ..............................................................133

Figura 52: Mapa de vegetação do Parque Nacional e Áreas

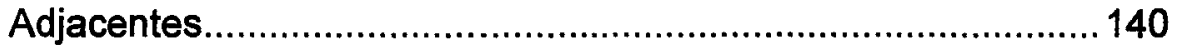

Figura 53: Localização das áreas da Fundação Ecotrópica transformadas em RPPN..................................................... 143

Figura 54: Dois remanescentes Guatós, Sr. José e Sr. Veridiano................ 144

Figura 55: Aspecto geral do Ninhal do Rio Negrinho, no entorno do

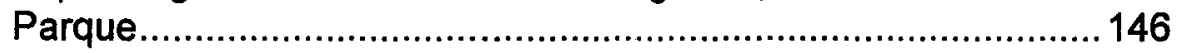

Figura 56: Vista da grande quantidade de ovos caídos dos ninhos ............ 146

Figura 57: Inscrições observadas na entrada da Baía Gaíva, parcialmente submersas ................................................... 148

Figura 58: Sede do PARNA do Pantanal Mato-Grossense recémreformada

Figura 59: Vista aérea da sede onde se observa 0 aterro recém-

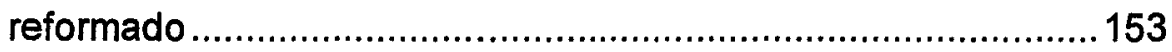

Figura 60: Porto flutuante que pode ser transformado em embarcação ..... 154

Figura 61: Aspectos da sede antes da reforma....................................... 154

Figura 62: Casa do funcionário após a reforma ....................................... 155

Figura 63: Área Indígena e Unidades de Conservação............................... 164

Figura 64: Formas e Áreas das Unidades de Conservação Federais

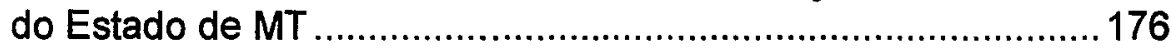

Figura 65: Dimensões e distribuições de reservas, recomendadas ............176 


\section{LISTA DE TABELAS}

Página

Tabela 01: Distância das Unidades de Conservação, localização e meios de transportes utilizados ...............................................27

Tabela 02: Quadro de Pessoal da ESEC …….......................................54

Tabela 03: Quadro de Pessoal da ESEC Serra das Araras .........................75

Tabela 04: Quadro de Pessoal do PARNA da Chapada dos

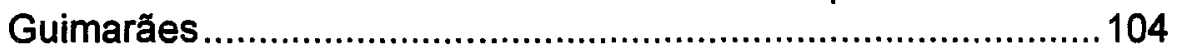

Tabela 05: Quadro de Pessoal da ESEC Taiamã .......................................126

Tabela 06: Tabela de Pessoal do PARNA Pantanal Matogrossense ........... 155

Tabela 07: Unidades de conservação Estaduais Decretadas ainda

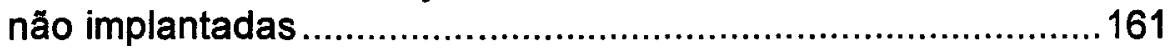

Tabela 08: Áreas Indígenas no Estado de Mato Grosso ................................165 


\title{
Análise das Unidades de Conservação Federais do Estado de Mato Grossoo
}

\author{
Autora: Nely Tocantins \\ Orientador: Prof. Dr. Alvaro Fernando de Almeida
}

\section{RESUMO}

O trabalho teve por objetivo investigar a situação das Unidades de Conservação Federais do Estado de Mato Grosso.

O estudo foi realizado nas seguintes Unidades: Parque Nacional do Pantanal Matogrossense, Parque Nacional de Chapada dos Guimarães; Estação Ecológica lquê-Juruena, Estação Ecológica Serra das Araras e Estação Ecológica Taiamã.

Os parâmetros utilizados para a pesquisa, foram baseados em sua maioria no "Roteiro Técnico para Elaboração de Planos de Manejo em Áreas Protegidas de Uso Indireto" (IBAMA, 1992).

Complementando o trabalho, foi realizado um apontamento das Unidades de Conservação Estaduais criadas e ainda não implantadas e um quadro sucinto da situação das áreas indígenas mato-grossenses.

Utilizou-se levantamentos de dados em Instituições Federais, Estaduais, responsáveis pelo gerenciamento da questão ambiental, junto aos pesquisadores que trabalharam nas Unidades anteriormente, e nas Organizações Não Governamentais envolvidas com as Unidades de Conservação, bem como viagens de campo às referidas Unidades.

As Unidades de Conservação Federais implantadas, foram criadas na década de 80 e representam cerca de $0,5 \%$ (aproximadamente 415.700 ha) da área do Estado, nas categorias de Parque Nacional e Estação Ecológica, localizadas nos três ecossistemas: pantanal, cerrado e floresta amazônica.

As Unidades criadas no Estado possuem áreas que variam de 16.000 ha a 200.00 ha, ainda não regularizadas em sua totalidade, comprometendo seus objetivos. 
O gerenciamento dessas Unidades tomou um impulso maior após a implantação do Programa PRODEAGRO (1992), que possui como exigência o comprometimento com o componente ambiental por parte do Estado.

A criação das Unidades apenas, não garante a conservação dos recursos naturais do Estado, sendo necessárias medidas de políticas públicas efetivas, bem como o envolvimento da sociedade civil nesse processo. 


\title{
Analysis of the Federal Units of Conservation in the State of Mato Grosso
}

\author{
Author: Nely Tocantins \\ Adviser: Prof. Dr. Alvaro Fernando de Almeida
}

\section{SUMMARY}

This assignment had for aim to investigate the situation of the Federal Units of Conservation in the State of Mato Grosso.

The study was realized in the following units: Pantanal Matogrossense National Park; Chapada dos Guimarăes National Park; lquê-Juruena Ecological Station; Serra das Araras Ecological Station and Taiamã Ecological Station.

The parameters used for the research were in their majority based on "Roteiro Técnico para Elaboração de Planos de Manejo em Áreas Protegidas de Uso Indireto" (IBAMA, 1992).

Supplementing the assignment, it was realized a quotation of the State Units of Conservation which were already created but are not functioning yet and a succint panel of Indian Areas located in Mato Grosso.

It was used a data survey in the Federal and State Instutions which are responsible for the management in the Ambiental Part, also with the researchers who worked in the in the Units before, and Non-Governmental Organizations that are involved with the units of Conservation, as well as the researching journeys to the already mentioned Units.

The Federal Units of Conservation, wich are functioning were created in the 80 's and they represent around $0,5 \%$ (about $415.700 \mathrm{ha}$ ) of the total area of the state, in the categories of National Park and Ecological Station, in the three existent ecossystem in the state: pantanal, savanas (cerrado) and amazon forest (amazônia).

The Units, created in the state, have an area that are since 16.000 ha till 200.000 ha, not regularized in their totalit yet, jeopardizing the objectives of their creation.

The manegement of these Units has been stronger after PRODEAGRO Plan, 1992 which has a demand the commitment, by part of the state, with the ambiental component.

Only the creation of the units didn't guarantee the conservation of the natural resources in the State. It's been necessary some effetive steps of the Public Politics, as well as the involvement of the Civil Society in this process. 


\section{Introdução}

O Estado de Mato Grosso, a partir da década de 60, foi envolvido por políticas oficiais, servindo como incorporador de correntes migratórias espontâneas e induzidas, para diminuir tensões em outras regiões do país. Nesse processo de ocupação, passou a ser visto como um espaço privilegiado para a agricultura e pecuária, resultando em sensíveis perdas de biodiversidade.

A partir de 1970, o processo de ocupação foi incentivado por programas especiais como: PIN (Programa de integração Nacional), PROTERRA (Programa de Redistribuição de Terras e Estímulo à Agro-Indústria), POLOCENTRO (Programa de Desenvolvimento dos Cerrados), POLAMAZÓNIA (Programa de Pólos Agropecuários e Agrominerais da Amazônia), PRODOESTE (Programa de Desenvolvimento do Centro Oeste), PRODEPAN (Programa de Desenvolvimento do Pantanal), POLONOROESTE (Programa Integrado de Desenvolvimento do Noroeste do Brasil), entre outros, impulsionados pelo governo federal, através da SUDAM (Superintendência do Desenvolvimento da Amazônia) e SUDECO (Superintendência do Desenvolvimento do Centro Oeste) (Castro \& Galleti, 1994).

Tanto o Governo Federal como o Estadual, intervieram em áreas que atingiram os três ecossistemas do território mato-grossense: pantanal, cerrado e floresta amazônica, os quais foram objeto de preocupações ambientais especificas, especialmente utilizados como justificativas de alguns projetos como 0 POLOCENTRO, POLAMAZÔNIA E POLONOROESTE.

A área desmatada no período de 70 a 90 para a agropecuária passou de 1.589.000 ha para 13.873 .000 ha e estima-se que o desmatamento avance 900.000 ha/ano, representando aproximadamente $1 \%$ da superfície do Estado (Programa de Desenvolvimento Agro Ambiental do Estado de Mato Grosso PRODEAGRO, 1992).

Os contingentes migratórios, principalmente os espontâneos ao se chocarem com a terra privatizada, entraram em conflito pela mesma, ou avançaram pela floresta amazônica ou sobre as terras indigenas, que atualmente representam $11 \%$ da área do Estado (com apenas $60 \%$ de suas terras demarcadas), o que tem gerado uma história de muitos conflitos (PRODEAGRO, 1992). 
O processo é agravado ainda mais, devido à falta de conhecimento dos potenciais e das limitações regionais por parte dessa nova população, à pouca expressividade das Unidades de Conservação, à falta de fiscalização e à falta de ordenamento territorial, que se paute nas potencialidades e limitações ecológicas, bem como à existência de políticas e incentivos conflitantes de recursos, CIMA (Comissão Interministerial para Preparação da Conferência das Nações Unidas Sobre o Meio Ambiente e Desenvolvimento, 1991).

A grande diversidade de ecossistemas, habitats e populações naturais do Estado de Mato Grosso: pantanal, cerrado e floresta amazônica, gera uma situação privilegiada de riqueza genética, implicando em maiores responsabilidades por parte do Estado (PRODEAGRO, 1992).

O rápido crescimento ocorrido no Estado de Mato Grosso, não garantiu o desenvolvimento social e tem provocado efeitos ambientais negativos, resultante desse modelo de exploração predatória dos seus recursos naturais.

Como existe uma lacuna no conhecimento sobre as Unidades de Conservação Mato-grossenses, esse trabalho tem por objetivo o levantamento da situação das Unidades de Conservação Federais, evidenciando a situação de cada uma delas, de acordo com alguns parâmetros propostos, tais como: situação histórica e geográfica das Unidades, características biofísicas, sócio-econômicas e culturais, áreas de influência e aspectos institucionais. 


\section{REVISÃO BIBLIOGRÁFICA}

\subsection{Fragmentação Florestal}

A fragmentação florestal é um dos fenômenos mais marcantes e graves do processo de expansão das fronteiras agrícolas nas regiões tropicais e sub-tropicais da América Latina, estando presente no Brasil em todas as etapas do processo, desde as mais antigas na Mata Attântica do Nordeste, até as atuais, nas áreas do Cerrado do Centro-Oeste e na Amazônia (Viana et al.,1992).

$\mathrm{Na}$ Amazônia o processo de fragmentação é relativamente recente, intensificando-se de forma quase exponencial a partir dos anos sessenta, com o início do programa de abertura de estradas e de concessão de incentivos fiscais para a conversão da floresta em outras formas de uso da terra, particularmente a pecuária, que em geral se inicia com o uso do fogo (Fearnside, 1986) .

Mesmo sendo recente o processo, há uma forte tendência para que toda sua área seja transformada, com o tempo, numa grande matriz de ecossistema agricola, pontilhada por fragmentos florestais (Tabanez, 1995).

São denominadas por Wilson \& Bassert (1971), "ilhas terrestres", os fragmentos circundados por vegetação marcadamente diferente, podendo variar 0 tamanho da "ilha", desde uma grande área até uma só árvore.

A Teoria da Biogeografia de llhas tenta estabelecer uma relação entre o tamanho da área e a diversidade de espécies, em que o número de espécies tende a aumentar quanto maior o tamanho da área, mantendo o equilíbrio baseado na taxa de migração e colonização dos seres vivos (Watts, 1971; Harris, 1984).

Mesmo considerando-se uma "ilha" como local não perturbado, observa-se a existência de variações dentro das comunidades animal e vegetal, em diferentes ilhas na mesma área geográfica e zona climática. Esta variação encontrase ligada a fatores ambientais como forma, tamanho, e localização da ilha (Diamond et al., 1982). Considerando-se mais alguns fatores, como histórico de perturbações, tipos de vizinhança e grau de isolamento, quando se trata de um fragmento perturbado, originado de vegetação contínua, deve seu isolamento a atividades antrópicas, capazes de diminuir em grande escala o fluxo de animais, de pólen e/ou 
de sementes (Viana, 1990; Whitmore, 1991). Este é um dos mais sérios problemas dos fragmentos, devido ao isolamento de populações pequenas, que têm sua sobrevivência ameaçada por problemas genéticos (Gilpin \& Soulé, 1986; Jarvinen, 1982) .

A área de um fragmento apresenta forte correlação com a diversidade biológica e a dinâmica da floresta. A relação entre a área e o número de espécies pode ser expressa pela equação $S=c A^{2}$, onde $S$ representa o número de espécies, $c$ uma constante, $\mathrm{A}$ a área, e $\mathrm{z}$ o coeficiente que determina a inclinação da curva. Por essa relação, o aumento do número de espécies em função da área aumenta em função do coeficiente $z$, que varia de local para local e tem de ser determinado empiricamente (Harris, 1984).

Os efeitos da forma dos fragmentos sobre a diversidade biológica e sustentabilidade da floresta, podem ser tão marcantes como os do tamanho.

Fragmentos de área arredondada ou circular apresentam uma baixa razão borda/interior, enquanto fragmentos alongados apresentam uma alta razão borda/interior, conforme a figura 01. Essa razão indica a fração da área do fragmento que se encontra sob o efeito de borda.

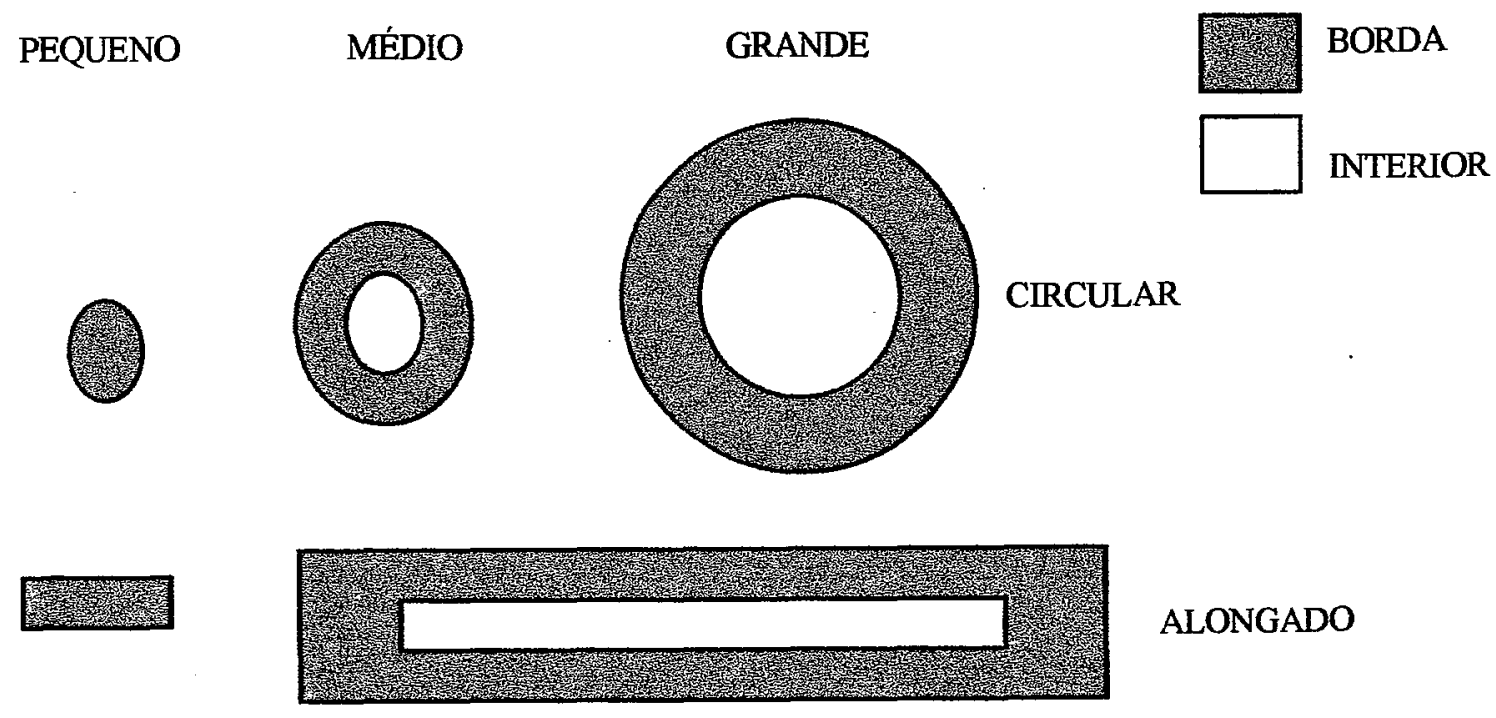

Fig 01-Representação da fração de borda e interior de fragmentos florestais de diferentes formas (circular e alongada) e tamanhos (pequeno, médio e grande) baseado em Forman e Godron citado por Viana, 1990. 
Com a fragmentação ocorrem mudanças imediatas e pronunciadas, iniciando-se pelas mudanças na luminosidade, temperatura, umidade e velocidade do vento, sendo mais pronunciadas na borda, diminuindo na direção do interior (Viana, 1990).

Segundo Bazzaz (1983), as áreas vizinhas de um fragmento florestal podem funcionar como: (i) barreira para o trânsito de animais, (ii) fonte de propágulos invasores, (iii) fonte de poluentes, (iv) fontes de perturbação, e (v) modificadores climáticos.

De acordo com Harris (1984), o grau de isolamento é um fator importante na determinação do tamanho efetivo de um fragmento, que é determinado pela (i) área, (ii) grau de diferença entre a vegetação vizinha e o fragmento e (iii) o grau de isolamento.

As conseqüências negativas do processo de fragmentação florestal amazônica levou à implementação do Projeto "Dinâmica Biológica de Fragmentos Florestais (PDBFF), também conhecido como "Minimum Critical Size of Ecossystems Project" (Tamanho Minimo de Ecossistemas). Este projeto é desenvolvido entre o INPA e o Smithsonian Institution, acerca dos efeitos da fragmentação sobre o sistema florestal e as suas implicações para o planejamento e manejo de áreas de proteção ambiental, com o objetivo de estudar o tamanho mínimo para reservas. Comparou-se uma área de floresta contínua e vários fragmentos, isolados pela atividade pecuária, de 1, 10, 100 e 1000 ha, realizando estudos dos impactos nas populações vegetais e animais causados pela fragmentação, os quais têm mostrado que, quanto menores as áreas, mais drásticos são seus efeitos (Lovejoy et al., 1986) .

Simberlof \& Abele (1982) chegaram à conclusão de que os critérios utilizados para a determinação de Refúgios de Vida Silvestre são um tanto empíricos, e que várias ilhas podem levar a um aumento no número de espécies, se comparadas com uma só ilha de tamanho igual ou maior, do que a soma dos fragmentos, devido ao favorecimento da diversificação de ambientes, no que discorda Cole (1981), afirmando existir maior diversidade em uma única ilha ou reserva, onde são menores os fatores impactantes, preservando-se uma área central suficientemente grande para a manutenção das populações naturais sem alterações. 
Segundo Cuttler (1991), no caso das espécies raras, a melhor maneira para protegê-las, é numa única grande reserva.

Atualmente vários autores discutem a necessidade de intervenção nos fragmentos, bem como em todo o sistema de áreas protegidas (Grumbine, 1994), que podem ser entendidas como fragmentos de ecossistemas. Essas áreas protegidas, consideradas normalmente como áreas contínuas, estão submetidas às mesmas pressões que os fragmentos (Janzen, 1983), em maior ou menor grau.

Vários autores (Burkey, 1989; Mwnalyosi, 1991; Fahrig \& Merrian, 1994), têm discutido nas propostas de manejo, vários fatores, como: tamanho mínimo e forma dos fragmentos, pontos básicos da sua dinâmica. Existem críticas ao consenso da maioria dos autores de que fragmentos grandes e arredondados sejam a melhor estratégia de conservação (Game, 1980; Simberloff, 1982; Simberloff \& Cox, 1987; Robinson et al.,1992).

0 aspecto mais grave da fragmentação florestal é a perda de biodiversidade. A redução da área de ecossistemas naturais quase sempre é acompanhada por diferentes perturbações, resultando numa preocupante perda de biodiversidade (Viana et al., 1992 ).

A perda de espécies em Parques, Reservas e ilhas, parece afetar mais certos grupos de espécies em detrimento de outros. Em geral, as espécies mais vulneráveis são aquelas representadas por populações reduzidas. Pequenas populações podem resultar da limitação de recursos temporais e espaciais (habitat altamente especializado ou fonte de alimento), ocorrendo que os grupos pertencentes a um único nível trófico têm maior probabilidade de extinção (Maurer, 1990).

Segundo Harris (1984), existem cinco fatores que influenciam a diversidade em fragmentos, levando à perda de espécies: 1) a distância entre as ithas e o tamanho da ilha em relação ao território; 2) as ilhas isoladas têm maior possibilidade de serem colonizadas, mesmo com baixa diversidade, por espécies migratórias; 3) o estabelecimento das espécies envolve tolerância e especificidade do habitat em relação à variação climática e ao gradiente vegetacional; 4) ○ grau de isolamento envolve um contínuo específico (para cada espécie) e é ditado em muitas situações, tanto pela biologia da espécie como pelas condições ambientais; 5) a simplificação ambiental diminui os habitats e alimento para algumas espécies. 
Todos esses fatores acarretam a extinção de espécies, porém em fragmentos isolados, o tamanho da população é um outro fator que pode levar à perda de espécies.

Segundo Shaffer (1981), ficam estabelecidos dois tipos de extinções: a extinção determinística (devida a variação demográfica e genética) e a estocástica (devida à variação ambiental e ocorrência de catástrofes).

A redução das populações conduziram a estudos sobre o tamanho ideal de uma População Mínima Viável (PMV), número mínimo de indivíduos que assegurem a permanência de uma população por um maior tempo possivel.

Segundo Gilpin \& Soulé (1986), para se determinar a PMV é necessária a análise das populações separadamente, pois cada espécie possui diferentes mecanismos de interação demográfica, ambiental e genética, que contribuem para a extinção: o fenótipo da população, incluindo todas as manifestações físicas, químicas e biológicas; e ambiente, incluindo todos os aspectos bióticos e abióticos. Estes dois fatores determinam o terceiro mecanismo: a estrutura populacional e a probabilidade de um indivíduo deixar descendentes férteis ("fitness"). Os fatores demográficos e genéticos agem em conjunto nas pequenas populações, formando um ciclo conhecido como redemoinho de extinção (Extinção Vortex), representado na figura 2.

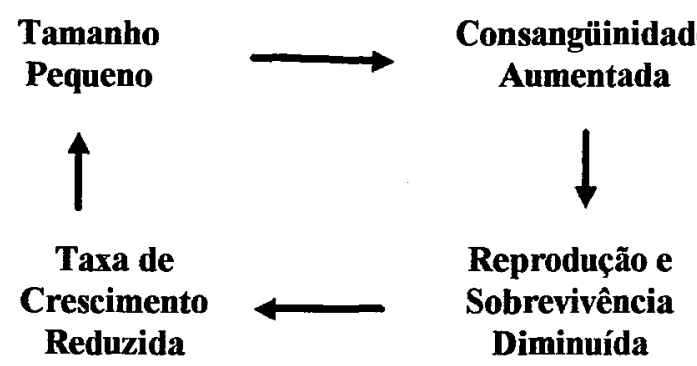

Fig.02- Representação esquemática da extinção "Vortex" (Foose,1992).

De acordo com Foose (1992), para a determinação do tamanho de uma população mínima viável, é necessário analisar as características biológicas da espécie, que implicam na duração de uma geração, no número de fundadores, no tamanho da população efetiva (NE) e taxa de crescimento. 
Para Ballou et al., (1992), uma tentativa de estimar a probabilidade de extinção e perda de variabilidade genética é chamada de Análise de Viabilidade Populacional (AVP), definida como uma avaliação sistemática da interação dos fatores que atuam sobre a população em risco de extinção, representado na figura 03.

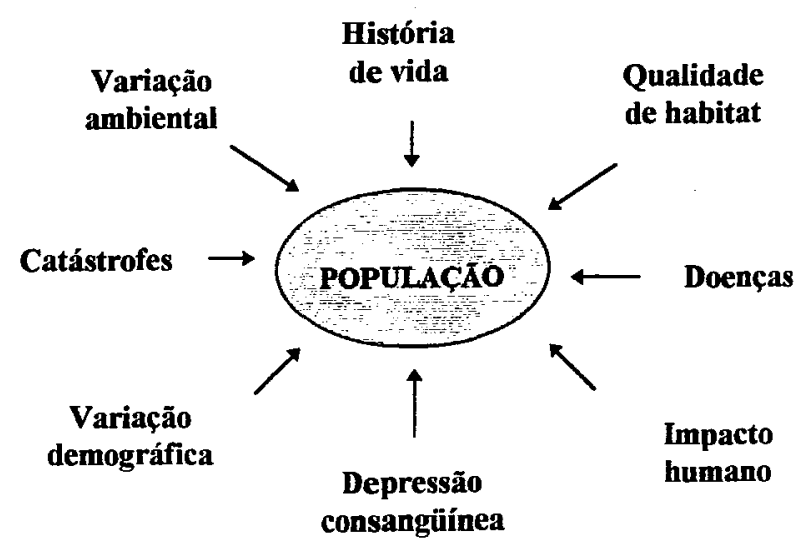

Fig 03 - Modelo de análise de viabilidade de população AVP, mostrando os efeitos de várias ameaças que contribuem na extinção e retenção da variabilidade genética (Foose, 1992).

Essa análise é importante para o desenvolvimento de estratégias que assegurem $95 \%$ de chances de sobrevivência da população, num período de tempo de 100 anos, mantendo-se $90 \%$ da sua variabilidade genética e segurança demográfica, segundo Schaffer (1981) e Foose (1992).

Em fragmentos isolados, as populações podem estar distribuídas em diferentes áreas isoladas, sendo chamadas de metapopulações (figura 04). A população mínima viável, neste caso, implica em áreas mínimas críticas de habitat natural.

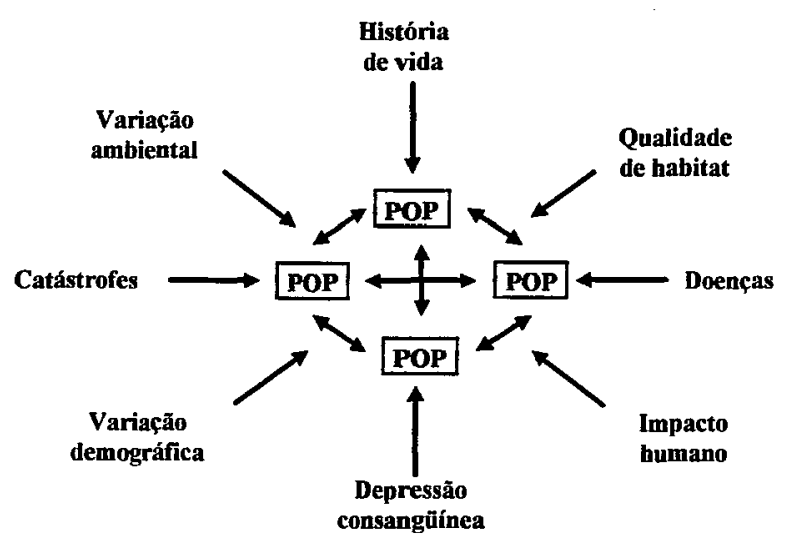

Fig.04 - Interação entre populações fragmentadas resultando em metapopulações (Foose, 1992). 
Para a conservação da PMV de metapopulações é necessário manter a população efetiva (NE) estável através da taxa de migração e se alguma subpopulação extinguir-se de um fragmento a metapopulação manter-se-á através de mecanismos de recolonização (Foose, 1992).

Entretanto, para algumas espécies isoladas a migração e a recolonização podem ser impossíveis, pois nem sempre os indivíduos migrantes influenciam na população efetiva (Foose, 1992).

É importante a compreensão de que proteger a biodiversidade, em termos práticos, não significa somente a proteção de áreas de tamanho razoável, pouco ou nada antropizadas, é também a proteção dos pequenos fragmentos, detentores de diversidade

\subsection{Unidades de Conservação}

Unidades de Conservação são porções do território nacional, incluindo águas territoriais, com características naturais de relevante valor, de domínio público ou propriedade privada, legalmente instituídas pelo Poder Público, com objetivos e limites definidos, sob regimes especiais de administração e às quais se aplicam garantias de proteção (FUNATURA, 1989 ).

A criação do Parque Nacional de Yellowstone, em 1872, nos Estados Unidos, é identificado como marco do moderno conceito de área protegida "wilderness", termo que o Brasil passou a adotar, seguindo tendências internacionais, como áreas protegidas ou Unidades de Conservação. Num contexto de valorização da manutenção de áreas naturais, são consideradas "ilhas", de grande beleza cênica e valor estético, que levariam o ser humano à meditação (Diegues, 1994).

Em 1876, André Rebouças, inspirado na experiência americana, propôs a criação de dois Parques Nacionais, o Parque de Sete Quedas e o da llha do Bananal, posicionando-se também contra os desmatamentos, e suas causas: o monopólio das terras e a escravidão (Pádua, 1987).

Segundo Carvalho citado por Diegues (1994), tiveram relevante papel para o movimento protecionista: Coelho Neto e Augusto Lima que em 1921, contribuíram para a criação do Serviço Florestal (criado posteriormente ao do Estado 
de São Paulo (1896). Também Leôncio Correia, Pedro Bruno, Euclides da Cunha, Affonso Arinos, Roquete Pinto, Alberto Torres, Gustavo Barrozo, deram suas contribuições em defesa da natureza brasileira, através de seus livros e escritos.

Em 1934, realizou-se a $1^{\text {a }}$ Conferência para a Proteção da Natureza, promovida pela "Sociedade dos Amigos das Árvores", por iniciativa de Alberto José Sampaio e Leôncio Correia. Nesse mesmo ano surgiram o primeiro Código de Caça e Pesca, o Código de Minas, o Código das Águas, e o Código Florestal (Carvalho, op. cit.).

O Código Florestal de 1934 conceituava, além dos Parques Nacionais, as Florestas Nacionais, suscetíveis de exploração econômica, áreas de preservação em propriedades privadas, as chamadas Florestas Protetoras.

A Constituição Federal de 1937, endossando a de 1934, que definiu as responsabilidades da União em proteger belezas naturais e monumentos de valor histórico, afirma, em seu artigo 134, que os monumentos históricos artísticos e naturais gozam de proteção e cuidados especiais da Nação, dos Estados e dos Municipios.

$\mathrm{Na}$ cidade de Itatiaia (1937), foi criado o primeiro Parque Nacional, no Rio de Janeiro, então capital do país, com o objetivo de incentivar a pesquisa cientifica e oferecer lazer às populações urbanas, cuja proposta inicial foi feita em 1913 por Alberto Lofgren.

No atual Distrito Federal, foi criada, em 1944, a primeira Floresta Protetora e em 1946, a primeira Floresta Nacional, na região nordeste (Workshop "Políticas de Unidade de Conservação", 1994).

Os primeiros Parques Nacionais Brasileiros foram conceituados a partir da idéia de criação de monumentos públicos naturais, com área delimitada, grande beleza cênica, com o objetivo de perpetuar "trechos do pais" que por sua singularidade tivessem valor cientifico e estético.

Em 1948, através do Decreto Legislativo $n^{\circ} 3$, foi aprovada a Convenção Para Proteção da Flora e da Fauna e das Belezas Cênicas dos Países da América, assinada anteriormente pelo Brasil em 1940. Definiram-se o Parque Nacional, a Reserva Nacional, o Monumento Natural e a Reserva de Região Virgem, 
como categorias de áreas de preservação (Workshop "Políticas de Unidade de Conservação", 1994).

Em setembro de 1944, pelo Decreto no 16 677, atribui-se à Seção de Parques Nacionais do Serviço Florestal (criado em 1921) o encargo de orientar, fiscalizar, coordenar e elaborar programas de trabalho, como também estabelecer os objetivos dos Parques Nacionais: conservar para fins científicos, educativos, estéticos ou recreativos, promover estudos da flora, fauna, geologia, bem como organizar museus, e herbários regionais (Diegues, 1994).

Dois anos após em 1939 foram estabelecidos os Parques Nacionais de Iguaçu (PR) e o da Serra dos Órgãos (RJ).

Do Código Florestal de 1934 até a instituição do Novo Código Florestal em 15 de setembro de 1965 foram criados: Parques Nacionais, Florestas Nacionais, Florestas Protetoras, Florestas Remanescentes e Reservas Florestais (Rocha op.cit.)

Através desse Novo Código (Lei n 4771 ), faz-se nova categorização de áreas públicas de preservação, sendo divididas em dois grandes blocos: aquelas em que se permitiria a exploração, como a Floresta Nacional, Estadual ou Municipal; e aquelas em que não se permitiria a exploração, como os Parques Nacionais, Estaduais e Municipais e as Reservas Biológicas.

Somente a partir da década de 60 , com a expansão da fronteira agrícola e a conseqüente destruição das florestas, foram criados Parques, fora do eixo sul-sudeste.

A expansão da fronteira agrícola para a Amazônia trouxe consigo a criação de algumas Unidades de Conservação, importantes para essa região, fruto da preocupação de cientistas e ambientalistas, devido ao rápido desmatamento da Amazônia (Quintão, 1983).

Como decorrência das recomendações da SUDAM foi instituído o Projeto RADAMBRASIL, que entre outras ações sugere a criação de vários Parques Nacionais e Reservas Biológicas, para proteger os ecossistemas e paisagens mais representativos detectados pelos levantamentos do projeto.

Criado em 1970, o Programa de Integração Nacional (PIN) previu a concretização de proposta apresentada pelo POLAMAZÔNIA, que era a criação do Parque da Amazônia. Dentre seus objetivos estavam incluídas definições de 15 pólos 
de desenvolvimento, com a recomendação, de que cada pólo específico deveria considerar a criação de Parques Nacionais, Reservas Biológicas, Florestas Nacionais e Parques Indigenas.

Em 1974, conforme recomendação, foi criado o Parque Nacional da Amazônia, com 1.000 .000 de ha (Quintão, 1983).

Em 1975, o II Plano Nacional de Desenvolvimento, também, previa a criação de novas unidades de conservação na região amazônica. E em 1979 três novos parques foram criados na região (Pico da Neblina, Pacaás Novos e Serra da Capivara) (Diegues, 1994).

Em 1979, através do Decreto $n^{\circ} 84.017$ foram regulamentados os Parques Nacionais Brasileiros e, logo após, sancionada a Lei $n^{\circ} 6.902$, que tratou da criação de Áreas de Proteção Ambiental e Estações Ecológicas em 1981.

Em 1984, através do Decreto $n^{\circ} 89.336$, ficaram definidas as Reservas Ecológicas e as Áreas de Relevante Interesse Ecológico.

Com a criação das Reservas Extrativistas através do Decreto $n^{\circ} 98.897$ em 1990, ocorreu uma significativa inovação ao nivel conceitual, quanto à categorização de Unidades de Conservação no Brasil, que contempla e favorece a permanência de populações tradicionais.

Nesse mesmo ano de 1990, através do Decreto $n^{\circ} 98.944$ foram reconhecidas como Reservas Particulares do Patrimônio Natural em caráter permanente, imóveis de domínio privado, onde fossem identificadas condições naturais primitivas.

E através do Decreto $n^{\circ} 1922$ de 05 de junho de 1996 foram realizadas alterações no sentido de se dar maiores alternativas de incentivo financeiro aos projetos das Reservas decretadas.

\subsection{Sistema Nacional de Unidades de Conservação}

O Sistema Nacional de Unidades de Conservação SNUC é considerado - conjunto de Unidades que, devidamente selecionadas, planejadas e manejadas como um todo, é capaz de viabilizar em objetivos nacionais de conservação. $O$ sistema refere-se, portanto, a um conjunto de unidades articuladas tanto 
geograficamente como por categorias de manejo (BRASIL/CONAMA, 1990; Milano, 1993).

Seguindo a recomendação do II Plano Nacional de Desenvolvimento (II PND), e o IBDF (criado em 1967 e ligado ao Ministério da Agricultura), teve início em 1975, o projeto intitulado "Uma Análise de Prioridades para a Conservação da Natureza na Amazônia", com o objetivo de definir um programa geral para a conservação da natureza na região, incluindo a identificação, com bases científicas, das áreas chaves a serem estudadas especificamente, para sua futura proteção (Quintão, 1983).

O inicio da caracterização da proposta de um sistema nacional ocorreu com o "Plano do Sistema de Unidades de Conservação do Brasil", que adotou critérios científicos, estabelecendo a região amazônica como prioritária, definindo em termos de localização, área e categoria de manejo, as Unidades de Conservação a serem criadas no país. As áreas foram definidas como prioritárias através da identificação de refúgios do Pleistoceno (Milano, 1993).

Resultado das recomendações, o Plano do Sistema de Unidades de Conservação do Brasil, cujo principal objeto era o estudo detalhado das regiões propostas como prioritárias do estudo anterior. Propunha-se o Plano de Sistemas e uma revisão das categorias de manejo existentes no Brasil, já que as duas categorias previstas por lei não eram suficientes para cobrir toda gama de objetivos requeridos por diversas outras áreas (Quintão, 1983).

O Plano do Sistema foi estabelecido num período de atuação distinto na conservação da natureza, tanto pelo IBDF (Instituto Brasileiro de Desenvolvimento Florestal) como pela SEMA (Secretaria Especial do Meio Ambiente). Elaborado pelo IBDF, considerou apenas as categorias de manejo a ele pertencentes e as Estações Ecológicas. Numa segunda etapa, o plano foi revisado e atualizado, e em 1982, definindo como categorias de manejo fundamentais os Parques Nacionais e Reservas Biológicas, e as Florestas Nacionais, como categoria adicional (Milano, 1993).

Independentemente a SEMA estabeleceu o que se pode chamar de uma rede própria de Unidades de Conservação, incluindo, basicamente, as Estações Ecológicas (áreas representativas de ecossistemas brasileiros, destinadas à realização de pesquisas básicas e aplicadas de ecologia, à proteção do ambiente 
natural e ao desenvolvimento da educação conservacionista, permitindo-se alteração antrópica em até $10 \%$ da área) e as Áreas de Proteção Ambiental (áreas normalmente vastas de propriedade privada nas quais, através de zoneamento e regulamentação, se define usos possíveis, com o objetivo de manter-se a qualidade ambiental).

A Resolução $n^{\circ}$ 11/87 do CONAMA parece ter dado início a tentativas de articulação de diferentes "tipos" de Unidades de Conservação adotando o termo de Unidade de Conservação para as categorias criadas pelo Poder Público: Estações Ecológicas, Reservas Ecológicas, Áreas de Proteção Ambiental, Parques Nacionais, Monumentos Naturais, Jardins Botânicos, Jardins Zoológicos, Hortos Florestais e Áreas de Relevante Interesse Ecológico (Workshop "Políticas de Unidades de Conservação, 1994).

Em 1988, o PNMA (Programa Nacional do Meio Ambiente), em negociação com o Banco Mundial, teve como proposta a revisão do Plano do Sistema de Unidades de Conservação, com vistas ao planejamento estratégico da unificação do sistema IBDF e SEMA. Ocorreu com a criação em 1989 do IBAMA (Instituto Brasileiro do Meio Ambiente e dos Recursos Renováveis) como instituição única, que passou a estabelecer e administrar as Unidades de Conservação. Nesse mesmo ano foi encomendada à FUNATURA (Fundação Pró-Natureza), uma reavaliação do Plano de Sistema de Unidades de Conservação estabelecido em 1979 (Workshop "Políticas de Unidades de Conservação, 1994).

As áreas silvestres foram agrupadas e caracterizadas segundo as categorias de manejo abaixo descritas (IBDF/FBCN, 1982 e Thelen \& Miller, 1976, citado por Silva,1996): 1.Categorias de manejo de importância nacional: a) Monumento Natural; b) Parque Nacional; c) Reserva Biológica; d) Santuário ou Refúgio da Vida Silvestre. 2. Categorias de manejo complementares: a) Estação Ecológica; b) Estrada-Parque; c) Reserva de Recursos (Reserva Florestal); d) Rio Cênico (Rio Nacional). 3. Categorias de manejo adicionais: a) Floresta Nacional; b) Monumento Cultural (Sítios Históricos); c) Parque de Caça; d) Parque Natural; e) Reserva de Fauna; f) Reserva Indígena; g) Reserva Extratitvista.

Ao longo dos anos a conceituação de novas categorias de áreas reservadas foi uma resposta às mudanças das demandas do poder público e da sociedade em relação às Unidades de Conservação. 
O primeiro anteprojeto de Lei sobre o SNUC (Sistema Nacional de Unidades de Conservação), data de 1988, vindo a ser elaborado pelo CONAMA (Conselho Nacional do Meio Ambiente), em 1990. Através da Mensagem $n^{\circ}$ 176/92, o Poder Executivo propõe a criação do SNUC, através do Projeto de Lei $n^{\circ} 2.892$ de 1992, que dispõe sobre os objetivos nacionais de conservação, com a finalidade de uma revisão conceitual e legal das Unidades de Conservação existentes no Brasil, instituindo-se dez categorias de Unidades de Conservação com características e objetivos claramente definidos.

O referido projeto de Lei encontra-se em tramitação desde 1992 na Comissão de Meio Ambiente do Congresso Nacional, para conversão em Lei, mesmo tendo sido um projeto submetido a um amplo e pioneiro processo de consulta à sociedade, através da realização de seis reuniões técnicas, nas cidades de Cuiabá, Curitiba, São Paulo, Rio de Janeiro, Salvador e Macapá, com o objetivo de proporcionar aos interessados de todas as regiões do país, iguais oportunidades de participar do processo de discussão desse projeto, encontrando- se engavetado há cinco anos.

\subsection{Projeto de Lei $n^{\circ} 2.892$ de 1992 - Das categorias de Unidades de Conservação}

Artigo 10 - As UC integrantes do SNUC serão reunidas em três grupos, com características distintas: I - Unidades de Proteção Integral; II - Unidades de Conservação Provisórias; III - Unidades de Manejo Sustentável.

Parágrafo $1^{\circ}$ - Nas Unidades de Proteção Integral haverá proteção total dos atributos naturais que tiverem justificado sua criação, efetuando-se a preservação dos ecossistemas em estado natural com um mínimo de alterações e admitindo apenas o uso indireto de seus recursos, excetuados os casos previstos nesta Lei.

Parágrafo $2^{\circ}$ - Nas Unidades de Conservação Provisória haverá, em caráter transitório, proteção total dos atributos naturais até que seja feita a definição da destinação através de estudos técnico-científicos, tolerado apenas o uso direto sustentável dos recursos por parte das comunidades tradicionais existentes no ato de criação. 
Parágrafo $3^{\circ}$ - Nas Unidades de Manejo Sustentável haverá proteção parcial dos atributos naturais, admitida a exploração de parte dos recursos disponiveis em regime de manejo sustentado, sujeita às limitações legais.

Artigo 11 - Integram o grupo das Unidades de Proteção Integral as seguintes categorias de UC: I - Reserva Biológica; II - Estação Ecológica; III - Parque Nacional, Parque Estadual, Parque Natural Municipal; IV - Monumento Natural; V Refúgio de Vida Silvestre.

Artigo 12 - As Reservas Biológicas se destinam à preservação integral da biota e demais atributos naturais, sem interferência humana direta ou modificações ambientais a qualquer título, excetuando-se medidas de recuperação de seus ecossistemas alterados e o manejo das espécies que o exijam a fim de preservar a diversidade biológica.

Artigo 13 - As Estações Ecológicas são áreas representativas de ecossistemas brasileiros, destinados à realização de pesquisas básicas e aplicadas de ecologia, à proteção do ambiente natural e ao desenvolvimento da educação ambiental.

Parágrafo $1^{\circ}$ - As pesquisas que modificarem os ecossistemas naturais poderão ser realizadas em áreas previamente delimitadas com base em estudos ecológicos, que somadas não ultrapassem em extensão $5 \%$ (cinco por cento) da Estação Ecológica, até o máximo de 1.500 ha (hum mil e quinhentos hectares).

Parágrafo $2^{\circ}$ - $\mathrm{Na}$ área restante, segundo se dispuser em regulamento, poderá ser autorizada a realização de pesquisas ecológicas que não venham acarretar modificações no ambiente natural.

Artigo 14 - Os Parques Nacionais, Parques Estaduais e Parques Municipais se destinam preservar áreas naturais ou pouco alteradas, abrangendo paisagens, ecossistemas e/ou sítios geológicos de grande interesse para atividades cientificas, educacionais e recreativas, de lazer, realizadas em obediência a Planos de Manejo.

Parágrafo Único - Enquanto não for elaborado o Plano de Manejo da Unidade, poderão ser autorizadas as atividades previstas neste artigo, segundo regulamentação elaborada pelo Órgão competente. 
Artigo 15 - Os Monumentos Naturais se destinam a preservar áreas restritas contendo predominantemente sítios geológicos, geomorfológicos e paisagens notáveis que, por sua singularidade, raridade, beleza ou vulnerabilidade exijam proteção, sem justificar a criação de outra categoria de UC, dada a limitação de área ou ausência de diversidade de ecossistemas.

Artigo 16 - Os Refúgios de Vida Silvestre são áreas destinadas a assegurar condições para a existência da flora local, bem como de fauna residente ou migratória, de importância significativa.

Artigo 17 - Integra os grupos das Unidades de Conservação Provisória a categoria de UC, denominada Reserva de Recursos Naturais, com a finalidade expressa no Artigo 10, Parágrafo $2^{\circ}$, desta Lei.

Artigo 18 - Integram os grupo da Unidades de Manejo Sustentável, as seguintes categorias de UC: I - Reserva de Fauna; II - Área de Proteção Ambiental; III - Floresta Nacional, Floresta Estadual e Floresta Municipal; IV - Reserva Extrativista.

Artigo 19 - As Reservas de Fauna são áreas naturais contendo populações de animais nativos, terrestres ou aquáticos, e habitats adequados aos estudos técnicos-científicos para a utilização econômica dos recursos faunísticos, respeitados os condicionamentos ecológicos.

Parágrafo Único - Ficam proibidas a caça amadorística e profissional nas reservas previstas neste artigo, bem como a comercialização dos produtos e subprodutos resultantes das pesquisas.

Artigo 20 - As Áreas de Proteção Ambiental são porções do território nacional e águas jurisdicionais de configuração e dimensões variáveis, submetidas a modalidades de manejo diversas, podendo compreender ampla gama de paisagens naturais, seminaturais ou alteradas, com características notáveis e dotadas de atributos bióticos e abióticos, estéticos ou culturais que exijam proteção para assegurar o bem estar das populações humanas, resguardar ou melhorar as condições ecológicas locais, manter paisagens e atributos naturais ou culturais importantes, ou experimentar técnicas e atitudes que permitam conciliar o uso da terra com a manutenção dos processos ecológicos essenciais.

Parágrafo Único - As Áreas de Proteção Ambiental podem incluir subáreas sob proteção integral, atuar como zona-tampão para proteger outras 
categorias de UC ou prover proteção paisagística e ecológica ao longo de estradas e rios cênicos.

Artigo 21 - As Florestas Nacionais, Estaduais e Municipais são áreas com cobertura florestal de espécies predominantemente nativas, destinadas à produção econômica sustentável de madeira e outros produtos florestais, proteção de recursos hidricos, pesquisas e estudos, manejo de fauna silvestre e atividades recreativas e de lazer em contato com a natureza, desde que compatíveis com as finalidades das Unidades.

Artigo 22 - As Reservas Extrativistas são áreas naturais ou pouco alteradas, ocupadas por grupos sociais que usam como fonte de subsistência a coleta de produtos da flora nativa ou a pesca artesanal e que as realizam segundo as formas tradicionais de atividade econômica sustentável e condicionadas a regulamentação específica.

Parágrafo $1^{0}$ - Além da extração de produtos nativos, somente serão toleradas atividades de subsistência, pelos grupos sociais ocupantes da área, para as quais se permitirão alterações ambientais em área percentual definida no respectivo Plano de Manejo.

Parágrafo $2^{\circ}$ - É vedada a extração comercial de madeira e a exploração de recursos minerais.

Artigo 23 - As UC poderão ser estabelecidas em áreas de domínio público ou de propriedade privada, respeitadas as determinações constantes desta Lei.

Parágrafo $1^{0}$ - As UC sob administração pública poderão ser federais, estaduais ou municipais.

Parágrafo $2^{\circ}$ - Somente poderão manter áreas de propriedade privada dentro dos seus limites as UC das categorias Reserva de Recursos Naturais, Refúgio de Vida Silvestre e Área de Proteção Ambiental, sujeitas à fiscalização governamental.

Parágrafo $3^{\circ}$ - $\mathrm{Na}$ categoria de Refúgio de Vida Silvestre, a manutenção de áreas sob domínio privado dependerá da possibilidade de compatibilizarem-se seus objetivos com a utilização da terra. 
Artigo 24 - Nos Refúgios de Vida Silvestre, Reservas de Recursos Naturais, Áreas de Proteção Ambiental e nas Reservas Particulares do Patrimônio Natural, previstas no Artigo 39 desta Lei, de acordo com os princípios constitucionais que regem o exercício de direito da propriedade, o Poder Executivo poderá estabelecer normas limitando ou proibindo atividades que conflitem com as finalidades da criação da área natural protegida.

Artigo 39 - Os Artigos $3^{\circ}$ e $6^{\circ}$ da Lei $n^{\circ} 4.771$, de 15 de setembro de 1965, passam a vigorar com a seguinte redação:

"Artigo $3^{\circ}$ - ...

f) a abrigar espécies da flora e fauna ameaçadas de extinção.

g) a proteger áreas de relevante interesse ecológico, assim declaradas pelo Conselho Nacional do Meio Ambiente.

"Artigo $6^{\circ}$ - O proprietário de floresta ou outras formas de vegetação natural, não preservadas nos termos desta lei, poderá gravá-la com perpetuidade, desde que verificada a existência de interesse público pela autoridade competente. $O$ vínculo constará de termo assinado perante a autoridade responsável e será averbado à margem da inscrição no Registro Público, sob o título de Reserva Particular do Patrimônio Natural" (Silva, 1996).

Além de estabelecer as linhas que definem as características de cada uma das Unidades de Conservação, o projeto estabelece normas para a criação, implantação e manutenção dessas unidades, destacando-se as seguintes:

a) as Unidades de Conservação serão criadas mediante atos do Poder Público, com base em estudos prévios demonstrando as razões técnico-científicas e sócio-econômicas que justificam sua criação; b) as Unidades de Conservação deverão dispor todas elas, exceto as Reservas de Recursos Naturais, de um plano de manejo; c) especial atenção deverá ser dispensada ao desenvolvimento de atividades de pesquisa científica e educação ambiental, nas Unidades de Conservação; d) cinqüenta por cento dos recursos arrecadados por cada Unidade de Conservação deverá ser aplicado na própria unidade arrecadadora.

O projeto também estabelece incentivos, isenções e penalidades, destacando-se: a) possibilidade de isenção do Imposto Territorial Rural para áreas de propriedade privada incluídas em Reservas de Recursos Naturais, Áreas de 
proteção Ambiental e Refúgios de Vida Silvestre; b) a possibilidade do proprietário privado de áreas naturais gravá-las com perpetuidade, sob o título de Reserva Particular do Patrimônio Natural, desde que verificada a existência de interesse público pelo órgão competente, não sendo consideradas áreas improdutivas para efeito de pagamento do ITR, podendo também ser isentas do pagamento do imposto.

\subsection{Planejamento de Unidades de Conservação}

\subsubsection{Plano de Manejo}

As Unidades de Conservação, devendo cumprir importantes funções ecológicas, científicas, econômicas, sociais e políticas no País, devem ter suas administrações e manejos fundamentados em princípios de planejamento atualizados e, portanto dinâmicos (Milano, 1993).

O "Plano de Manejo" da Unidade de Conservação é o resultado do planejamento, considerado como uma técnica ou instrumento de organização de processos futuros que permitam otimizar as ações destinadas a alcançar os objetivos propostos. Esse Plano de Manejo, que contém as orientações e informações ao adequado desenvolvimento das atividades e ações necessárias para se alcançar os objetivos, constitui-se no documento norteador do diretor da Unidade na sua administração (Milano, 1993).

Segundo Milano (1993), um plano que predetermina suas atividades para alcançar seus objetivos, deverá contemplar três aspectos fundamentais: a) deve tratar sobre o futuro; b) deve implicar numa ação; c) deve identificar as pessoas e organizações que realizarão as atividades.

O plano deve ser entendido apenas como uma fase de um longo processo de planejamento, uma vez que deverá ser modificado à medida que novas informações sejam obtidas ou ocorram circunstâncias que acarretem mudanças na área (Milano, 1993).

O Plano de Manejo é elaborado de forma a planejar os próximos cinco (05) anos de gestão das Unidades devendo ser revisado após esse período. 
Uma Unidade de Conservação pode sofrer dois tipos de manejo: o moderado e o intensivo, dependendo da existência ou não de um plano de manejo. $O$ manejo moderado é o tipo de manejo realizado quando a unidade não conta ainda, com Plano de Manejo. Sem objetivos claros e bem definidos, as ações ficam restritas a processos empíricos, experiências positivas de outras unidades(quando delas se tem conhecimento) e à proteção possivel dos recursos naturais e da infra-estrutura existentes na Unidade. Manejo intensivo (refere-se a maneira ordenada de desenvolvimento da administração e manejo da Unidade) é adotado quando a Unidade de Conservação possui Plano de Manejo, sendo então desenvolvidas as atividades nele previstas, visando alcançar os objetivos programados (Milano, 1993).

\subsubsection{Plano de Ação Emergencial}

O Plano de Ação Emergencial (PAE), é um instrumento que visa planejar as atividades a serem realizadas em uma Unidade de Conservação, estabelecendo ações a curto prazo que possibilitem o processo de gestão, sendo prevista a efetivação dessas medidas em dois anos (Workshop "Políticas de Unidades de Conservação", 1994).

Segundo Milano (1993), na prática são documentos que se constituem em pré-planos de manejo, desenvolvidos a partir de levantamentos expeditos na área da Unidade.

São elaborados conforme metodologia e linguagem únicas para todas as unidades, consistindo em planejamento participativo de entidades públicas ou privadas e demais segmentos da sociedade diretamente relacionados com as Unidades (Workshop "Políticas de Unidades de Conservação", 1994).

Os Planos de Ação Emergencial são efetuados tanto para as Unidades que ainda não têm Plano de Manejo, quanto para aquelas que possuem o Plano de Manejo a ser revisado. Surgiram da necessidade de assegurar proteção às àreas antes mesmo da elaboração dos Planos de Manejo (Workshop "Políticas de Unidades de Conservação", 1994). 


\subsubsection{Plano Operativo Anual}

O Plano Operativo Anual é o planejamento das atividades a serem realizadas na Unidade a cada ano, elaborado pela chefia da unidade, onde detalha-se as previsões orçamentárias e o periodo de execução de cada meta definida no Planos de Ação Emergencial e de Manejo (Workshop "Políticas de Unidades de Conservação", 1994).

\subsubsection{Intervenção na Zona de Entorno}

A Resolução no 13 de 06/12/90 do CONAMA determina como Zona de Entorno toda a área localizada num raio de $10 \mathrm{~km}$ além dos limites da Unidade de Conservação, área onde qualquer ação que gere alterações na biota deve ser licenciada.

\subsection{Categorias de Unidades de Conservação do Estado de Mato Grosso}

As categorias representadas no Estado do Mato Grosso ao nivel Federal são: o Parque Nacional do Pantanal Matogrossense; o Parque Nacional da Chapada dos Guimarães; a Estação Ecológica Iquê-Juruena; a Estação Ecológica Taiamã e a Estação Ecológica Serra das Araras, todas elas implantadas e atualmente geridas pelo IBAMA, através do NUC (Núcleo de Unidades de Conservação) da SUPES/MT (Superintendência do Estado do Mato Grosso).

Em nivel Estadual foram criadas, mas ainda não implantadas as seguintes Unidades: a Reserva Ecológica do Culuene; a Reserva Ecológica de Apiacás, o Parque Estadual de Águas Quentes, o Parque Estadual da Serra Azul, a Área de Proteção Ambiental da Chapada dos Guimarães, a Área de Proteção 
Ambiental Pé da Serra Azul, a Reserva Extrativista Roosevelt-Guariba e a EstradaParque ${ }^{1}$ Transpantaneira.

Foram declaradas, pelo Governo do Estado em 1992, como áreas de interesse público para fins de estudo, visando a implantação de Unidades de Conservação as seguintes áreas: I - Serra do Cachimbo, II - Rio Madeirinha, III Pantanal do Rio das Mortes, IV - Cabeceiras do Rio Cuiabá, V - Serra Ricardo Franco, VI - Serra de Santa Bárbara, VII - Rio Ronuro.

Dessas áreas reservadas, foram criadas recentemente: o Parque Estadual Serra de Santa Bárbara, o Parque Estadual Serra Ricardo Franco, a Estação Ecológica Rio Roosevelt e a Estação Ecológica Rio Madeirinha, todas elas geridas pela FEMA (Fundação Estadual do Meio Ambiente) através da DUCO (Divisão de Unidades de Conservação). Observar figura 05.

\footnotetext{
${ }^{1}$ Estrada-Parque é um parque linear, que tem por objetivo de manejo manter parte ou toda uma estrada ou rodovia em estado natural ou semi-natural, proporcionando usos recreativo e educativo; o tamanho da área, está relacionado com a topografia e características da rede viária objeto da proteção (Milano, 1993).
} 

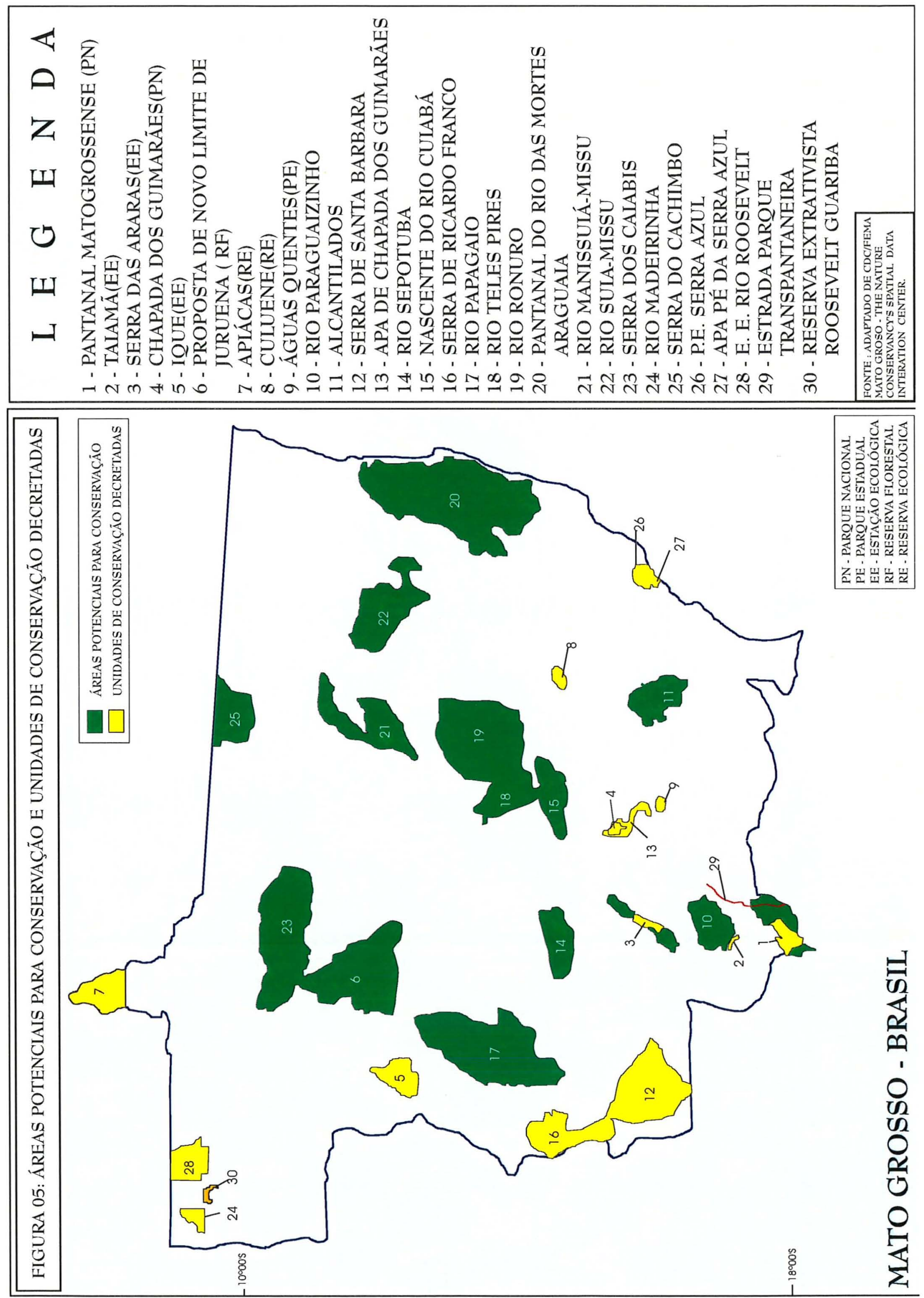


\section{MATERIAL E MÉTODOS}

\subsection{Caracterização Geral da Área}

O Estado de Mato Grosso possui uma extensão de $901.000 \mathrm{~km}^{2}$, abrangendo 127 municípios, situando-se entre os paralelos $7^{\circ} 20^{\prime} 31^{\prime \prime}$ e $18^{\circ} 10^{\prime} 0^{\prime \prime}$ de Latitude Sul e os Meridianos 50 $13^{\prime} 48^{\prime \prime}$ e $61^{\circ} 31^{\prime} 00^{\prime \prime}$ a Oeste de Greenwich.

Os seus limites estendem-se por $4.750 \mathrm{~km}$, dos quais $520 \mathrm{~km}$ com o Estado do Amazonas e $1120 \mathrm{~km}$ com o Estado de Goiás, a leste: $600 \mathrm{~km}$ com o Estado de Mato Grosso do Sul; $740 \mathrm{~km}$ com o Estado de Rondônia e $750 \mathrm{~km}$ com a Bolívia, a Oeste.

Em termos de posicionamento geopolítico, Mato Grosso representa $10,35 \%$, do território Nacional, valendo-se destacar sua posição geográfica e participação político-administrativa ao nível das regiões Centro-Oeste e Amazônia Legal.

A rede hidrográfica do Estado é formada pelas Bacias Amazônicas (602 $\left.327 \mathrm{~km}^{2}\right)$, Tocantins -Araguaia $\left(110140 \mathrm{~km}^{2}\right)$ e a do Paraguai (168 $\left.534 \mathrm{~km}^{2}\right)$.

O revestimento florestal do Estado, segundo Silva (1988), apresenta os principais tipos de formação vegetal: Floresta Ombrófila Densa, Floresta Ombrófila Aberta, Floresta Estacional Semidecidual, Savanas com todas as suas gradações, campos, e áreas de tensão ecológica.

\subsection{Proposta de Trabalho}

A proposta deste trabalho está baseada na consulta bibliográfica, levantamentos e recuperação de dados produzidos anteriormente, mesmo ao nível preliminar realizados nas Unidades de Conservação Federais implantadas no Estado de Mato Grosso.

Para tal, formalizou-se um processo para a obtenção de Licença para Pesquisa em Unidade de Conservação, obtida sob o número 096/95, onde ficou acordado a utilização do apoio logístico nas Unidades de Conservação, na dependência das disponibilidades. A autorização válida para as seguintes Unidades 
de Conservação: Parque Nacional da Chapada dos Guimarães, Parque Nacional do Pantanal Matogrossense; Estação Ecológica lquê-Juruena; Estação Ecológica Serra das Araras, e Estação Ecológica Taiamã.

Foram realizadas viagens de campo à todas as Unidades de Conservação pelo menos uma vez, devido às distâncias e dificuldades de acesso.

As viagens às Unidades Federais no Estado, tiveram início em dezembro de 95 e encerraram-se em abril de 96, realizadas, juntamente com os funcionários da equipe do NUC/SUPES/MT (Núcleo de Unidades de Conservação da Superintendência Estado de Mato Grosso).

As coletas dos dados sobre as Unidades de Conservação foram realizadas em Órgãos Governamentais Federais, Estaduais, e ONG'S engajadas com a conservação, como: IPECA (Instituto de Pesquisas Currupira Arara), OPAN (Operação Anchieta), ECOTROPICA (Fundação de Apoio à Vida nos Trópicos), e ARCA (Associação Para Recuperacão e Conservação do Ambiente) ).

O trabalho foi elaborado a partir da compilação de dados, quando disponibilizados, nesses órgãos, como: mapas, levantamentos, resultados dos projetos e documentação em geral, e posteriormente complementados com informações provenientes do cadastramento de documentação técnico-científica e informações fornecidas por pesquisadores, realizadas nas Unidades de Conservação do Estado.

Os parâmetros utilizados para a pesquisa foram baseados no "Roteiro Técnico para Elaboração de Planos de Manejo em Áreas Protegidas de Uso Indireto "(IBAMA, 1992). Também foram utilizados os PAEs (Plano Ação Emergencial) dos PARNAS do Pantanal Matogrossense e de Chapada dos Guimarães, realizados respectivamente em 1994 e 1995.

Durante as viagens foram realizadas observações fatuais, visando-areunir informações e procedidas entrevistas com os chefes da UC's, muitas vezes ocorrendo num momento de transição. As entrevistas com os funcionários lotados nas Unidades versaram sobre questões gerais das UC.

Os mapas de localização da UC's foram plotados, com base nos limites de seus memoriais descritivos e informações de antigos mapas do IBAMA sendo utilizadas as cartas topográficas: Cuiabá SD 21-Z.C, Barra do Bugres SD. 21-Y-D, 
Cáceres SE 21-V-B, Garapu SD 22-V-C, Juina SC 21 -Y-C, Aldeia Espirro SD.21-V-A, Morraria da ínsua SE.21-V-D, todas na escala de 1:250.000.

As viagens de campo tiveram como ponto de partida, a cidade de Rondonópolis, conforme demonstra a tabela 01 a seguir:

Tabela 01 - Distância das Unidades de Conservação, localização e meios de transportes utilizados.

\begin{tabular}{|c|c|c|c|}
\hline $\begin{array}{l}\text { Unidade de } \\
\text { Conservação }\end{array}$ & $\begin{array}{c}\text { Distância da UC } \\
\text { partindo de } \\
\text { Rondonópolis }\end{array}$ & $\begin{array}{c}\text { Município de } \\
\text { Jocalização da UC }\end{array}$ & Meio de transporte \\
\hline E.E.lquê-Juruena & $2.140 \mathrm{~km}$ & Juína & Rodoviário \\
\hline $\begin{array}{lll}\text { E.E. } & \text { Serra } & \text { das } \\
\text { Araras } & & \\
\end{array}$ & $1020 \mathrm{~km}$ & Porto Estrêla & Rodoviário \\
\hline E.E. Taiamã & $1.000 \mathrm{~km}$ & Cáceres & Rodov./fluvial \\
\hline $\begin{array}{l}\text { PARNA Pantanal } \\
\text { Matogrossense }\end{array}$ & $950 \mathrm{~km}$ & Poconé & Rodov./fluvial \\
\hline \begin{tabular}{|l} 
PARNA. Chapada \\
dos Guimarães
\end{tabular} & $600 \mathrm{~km}$ & $\begin{array}{l}\text { Chapada dos } \\
\text { Guimarães }\end{array}$ & Rodoviário \\
\hline
\end{tabular}




\section{RESULTADOS}

\section{I. ESTAÇÃO ECOLÓGICA IQUÊ-JURUENA}

\section{I.1 Situação Histórica e Geográfica}

\section{I.1.1. Localização e Limites Atuais.}

A Estação Ecológica lquê-Juruena, foi criada pelo Decreto Federal $\mathrm{n}^{\circ}$ 86.061 de 02 de junho de 1981, com uma área de 200.000 ha, com as seguintes coordenadas geográficas: entre as latitudes $11^{\circ} 30^{\prime}-12^{\circ} 15^{\prime} \mathrm{S}$ e longitudes $58^{\circ} 40^{\prime}$ $59^{\circ} 20^{\prime}$ Wgr. Localiza-se na porção sudoeste do Município de Juína, à margem esquerda do Rio lquê, afluente do Rio Juruena. (Figura 07).

A Estação limita-se ao sul com a margem esquerda do Rio lquê e ao norte com a rodovia MT-319 ou AR-1, não pavimentada. Do outro lado dessa rodovia, limita-se num trecho a noroeste, com o Parque Indígena Aripuanã.

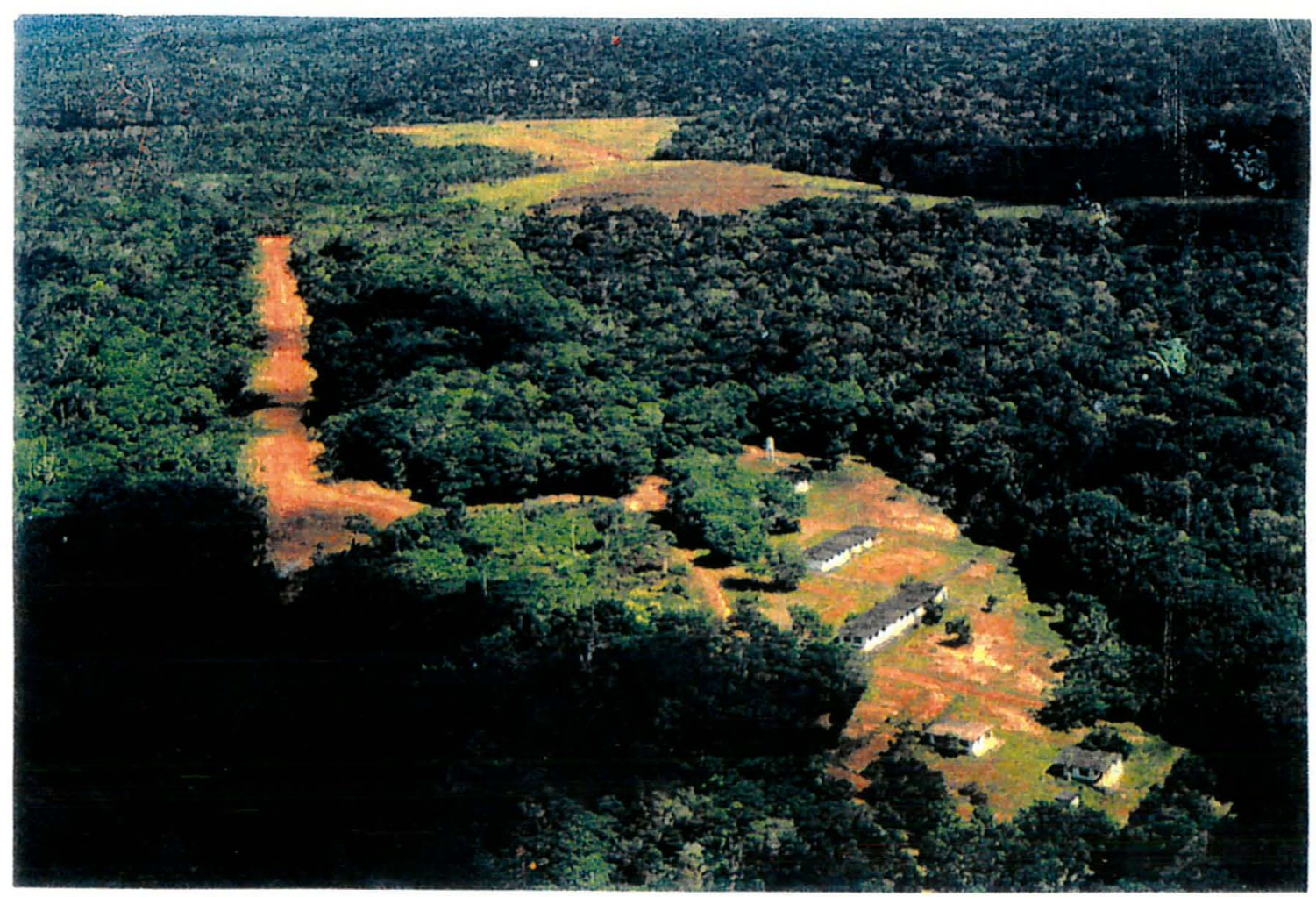

Figura 06 - Vista aérea da sede e campo de pouso da Estação Ecológica Iquê-Juruena. 


\section{I.1.2. Vias de Acesso}

A Estação Ecológica lquê-Juruena é acessível por via terrestre, em estrada não pavimentada. $O$ acesso faz-se a partir de Cuiabá (MT) até Vilhena (RO), percorrendo-se aproximadamente $752 \mathrm{~km}$ pela BR 364 ou por via aérea (vôos diários). De Vilhena (RO), parte-se pela rodovia MT-319 ou AR-1, para Juína, num trecho de $140 \mathrm{~km}$ até a sede da Estação (MT), ou parte-se de Juína, Município que dista de Cuiabá cerca de $800 \mathrm{~km}$, pela MT-170, daí seguindo-se pela MT-319 (AR-1) por volta de $100 \mathrm{~km}$ até a sede da Estação, que é servida por uma empresa rodoviária. Atualmente esta estrada encontra-se em condições precárias, sendo o percurso realizado, com aproximadamente 6 a 7 horas de viagem.

\section{4.l.1.3. Histórico da Unidade de Conservação e Antecedentes Legais}

O então Secretário do Meio Ambiente, Dr. Paulo Nogueira Neto, foi procurado na SEMA, pelo naturalista Arne Sucksdorff, informando-o que, no noroeste do Estado de Mato Grosso, existia uma área enorme, de solos arenosos, impróprios para agricultura e que valeria a pena a implantação de uma Estação Ecológica.

Através dessa informação, procurou-se o então diretor da CODEMAT, entidade de terras e desenvolvimento do Estado de Mato Grosso, Gabriel Müller, que achou viável a idéia de estabelecer uma Estação Ecológica na região do Rio lquê.

Foi porém, na gestão de Guilherme de Abreu Lima, que foram determinados os trabalhos topográficos para a locação dos limites, abrangendo cerca de 500.000 ha, que a princípio fora aceita pelo então governador do Estado José Garcia Neto. O Projeto de Lei, foi remetido para apreciação da Assembléia Legislativa, onde chegou-se à conclusão que 500.000 ha, seria uma extensão muito grande para ser doada à União (Nogueira Neto, 1991).

Houve então, a proposta, por parte da SEMA, de redução da área para 266.000 ha, ou seja, um pouco mais da metade do que fora proposto anteriormente, sendo assim, aprovada pela Assembléia Legislativa de Mato Grosso, através da Lei $\mathrm{n}^{\circ}$ 3.909 de 19 de setembro de 1977 e a doação feita através do Decreto 
Governamental no 12 de 19 de abril de 1979 e as terras inscritas no Serviço do Patrimônio da União (Nogueira Neto, 1991).

A Estação foi formalmente estabelecida pelo Decreto Federal $n^{\circ} 86081$ de 02 de junho de 1981, com 200.000 ha.

A delimitação das terras, estabelecida nesse Decreto foi precedida de entendimentos entre a SEMA, a FUNAI e o INTERMAT, em outubro de 1979. Em seguida a SEMA cedeu, por intervenção do representante da Missão Anchieta, uma área para os índios Enaunê, de aproximadamente 50.000 ha, excluída dos Decretos Estadual e Federal, perdendo com isso terras situadas à margem esquerda do Rio Juruena e a maior parte do Rio lquê (Nogueira Neto, 1991).

Ressalta-se no processo, a participação e dedicação do representante da SEMA no Estado de Mato Grosso, Paulo Rezende (Nogueira Neto, 1991).

\section{I.2. Características Biofísicas da Estação}

\section{I.2.1. Clima}

O municipio de Juína, na qual está inserida a Estação Ecológica, possui clima equatorial quente e úmido, com três meses secos, geralmente junho, julho e agosto, com temperaturas quase que constantemente elevadas, principalmente na primavera, ficando a temperatura média em torno de $26^{\circ} \mathrm{C}$. A média anual é de aproximadamente $24^{\circ} \mathrm{C}$, enquanto a média das máximas e das mínimas chega a atingir os valores de $32^{\circ}$ a $34^{\circ} \mathrm{C}$, e de $12^{\circ}$ a $14^{\circ} \mathrm{C}$, respectivamente.

Sua pluviosidade anual oscila entre 2.250 a $2500 \mathrm{~mm}$, com média de $2300 \mathrm{~mm}$, sendo $45 \%$ deste total anual, precipitado nos meses de janeiro, fevereiro e março (Fundação Júlio Campos, 1993).

\section{I.2.2. Geologia e Geomorfologia}

A região da Estação Ecológica lquê-Juruena pertence ao período Cretáceo-Mezosóico, fazendo parte da área denominada Grupo Parecis, que se apresenta em sua maioria na formação Utiariti, e ao sul a formação Salto das Nuvens, de menor ocorrência. 
Pode-se definir a área da Estação em duas sub-unidades: a primeira compreendida entre a base do costão e meio da reserva no sentido norte-sul, cabendo dentro da unidade geomorfológica conhecida como Planalto dos Parecis, embora transite para a depressão Meridional, sendo suas características gerais, altitudes médias variando entre 200 e $400 \mathrm{~m}$, ligeiramente rampeada com declinio de sul para norte. As escarpas erosivas são esculpidas em litologias do grupo Parecis (arenitos) (Brasil \& Alvarenga, 1988).

A segunda área, da região central ao topo da pirâmide, encontramos a depressão da Amazônia Meridional, cujo piso regional possui altitudes entre 200 e $300 \mathrm{~m}$ em média, com a presença de morros residuais.

\section{I.2.3. Hidrografia}

Essa região possui vasta rede de drenagem, bastante diversificada, cobrindo toda a extensão da Estação Ecológica destacando-se rios importantes, como o Rio Juruena e Aripuanã (possui suas nascentes na Estação), outros menores como - lquê e seus afluentes da margem esquerda, Rio Arimena, limite da Estação, Rios Joaquim Rios e Olowiná e seus tributários, além de lagoas marginais, bem como áreas alagáveis.

Ressalta-se o aspecto da limpidez de suas águas, baixa turbidez, ou seja pequena quantidade de material em suspensão. Tal fato deve-se à natureza arenosa dos solos, e à litologia dominada por materiais psamíticos, refletindo a natureza distrófica do ambiente, principalmente os solos e consequentemente suas águas.

A morfologia do Rio Juruena apresenta padrão meândrico de drenagem, favorecendo a formação de diversas lagoas do tipo "ferradura", com ligações periódicas ou durante o período das cheias (dezembro-março). Estes ecossistemas, representam na maioria das vezes, espaços utilizados como "viveiros" ou "criadouros naturais de comunidades de peixes, contribuindo também para o estabelecimento de condições ecológicas e mantém alta produtividade biológica (Higa \& Silva, 1995). 
O Rio Juruena e seus tributários integram a bacia do Tapajós, sendo caracterizados por possuírem águas claras e transparentes, com pouca quantidade de matéria inorgânica em suspensão e matéria orgânica e inorgânica dissolvidas, estando numa posição intermediária entre rios de água preta e os de água branca (Higa \& Silva, 1995).

\subsubsection{Solos}

A maioria dos solos da Estação Ecológica lquê-Juruena, pertence à classe das areias quartzosas álicas, podendo apresentar-se isolado, em relevo plano e suavemente ondulado (Higa \& Silva, 1995).

\section{I.2.5. Vegetação}

\section{I.2.5.1. Região de Savana (Cerrado)}

Nos extensos planaltos dissecados pelos Rios Juruena, Camararé, Doze de Outubro e seus tributários, e nas chapadas pequenas, remanescentes nessa área, a formação dominante é a savana.

Corroborando informações de Higa \& Silva (1995), através de constatação in $10 c 0$, verifica-se a existência de "areais", contrastante com a fitofisionomia da região, com vegetação herbácea e arbórea do porte do cerrado, fixada em formas circulares e irregulares na transição para o cerrado. Verifica-se em áreas distantes de influência fluvial, o que leva os autores a supor a ocorrência do processo de arenização. Esses areais são constituidos por areias quartzosas brancas. Regionalmente, esses locais são chamados de "reboleiras", sendo muito atrativos principalmente para a mastofauna, devido a grande oferta de alimento. (Figura 08).

\section{I.2.5.2. Floresta Estacional Sub-Montana}

Essa formação é caracterizada dentro da região ecológica pela sua altimetria, que varia de 100 a 500 metros. No Planalto Central e Centro Oeste do Brasil, ocorre nas cabeceiras do rio Xingú e no Planalto dos Parecis em forma de 
encraves com a Floresta Aberta. Nessa formação existe um sub-bosque arbustivo, e enorme quantidade de plântulas de regeneração natural.

Suas principais características ficam por conta de árvores emergentes deciduais, como: Cariniana spp (jequitibás), Aspidosperma spp. (perobas), Cedrela spp. (cedros), Piptadenia spp. (angicos), Peltophorum sp. (canafístula) e outras (RADAMBRASIL, 1980, Higa \& Silva, 1995).

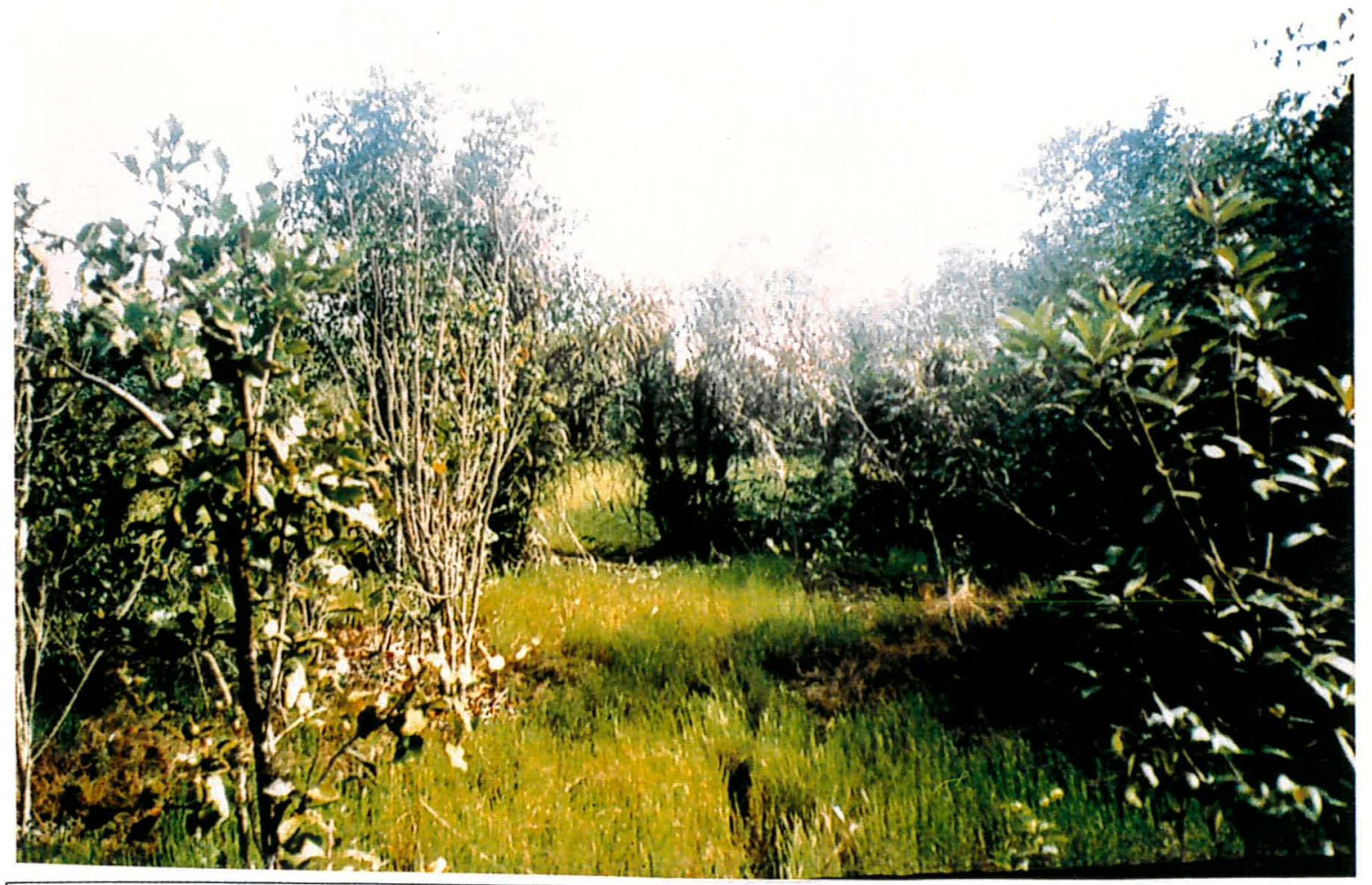

Figura 08 - Aspecto da "reboleira", junto a rodovia AR-1.

\section{I.2.5.3. Contato Savana / Floresta Estacional}

Esta região, (RADAMBRASIL, 1980), de contato Savana/ Floresta Estacional localiza-se no planalto Dissecado dos Parecis em terrenos do Terciário e do Cretáceo, de preferência nos latossolos vermelho-amarelos e areias quartzosas. $\mathrm{Na}$ composição florística desta comunidade, aparecem espécies da Floresta Estacional Semidecidual e da Savana Arbórea Densa, misturadas de maneira bastante homogênea, com aspecto de mata. Apresentam árvores deciduais que deixam cair suas folhas, total ou parcialmente, nos meses de julho e agosto, ficando o 
solo coberto de densa camada de folhas secas. Segundo alguns autores, essa vegetação é descrita como floresta de transição. Compõe sua estrutura, árvores de 20 a $25 \mathrm{~m}$ de altura, com finos diâmetros. $O$ sub-bosque se mantém limpo e de fácil penetração, com pequena quantidade de cipós. Reduzido número de palmeiras, sendo a bacaba (Oenacarpus bacaba) a maior ocorrência nestas áreas.

As espécies florestais de maior ocorrência arroladas na amostra do trabalho de Higa \& Silva (1995), foram: Cenostigma macrophyllum, Bowdichia virgiloides, Hirtella glandullosa, Terminalia sp., Protium aracouchini, tamacaré (Caraipa grandiflora), envira (Guatteria poeppigiana), Ocotea opifera, Roupala montana, umiri (Humiria balsamifera), cariperana (Licania membranaceae), abiorana (Prieurella prierii), breu-branco (Protium palidum) e Jacaranda decurrens.

O domínio de clima equatorial, em transição para um clima menos úmido, impõe uma paisagem também de transição de floresta amazônica subcaducifólia para uma fisionomia de cerrado, que se vê penetrando por matas de galerias construídas por espécies amazônicas.

É interessante notar que a medida em que essas matas de galeria se deslocam para o sul, são mais confinadas às calhas fluviais, apresentando redução em sua altura.

A floresta subcaducifólia dominando ao norte, possui vegetação de alto porte, troncos finos e copas pouco desenvolvidas. Os estratos mais elevados são constituídos por árvores emergentes caducifólias (Fundação Júlio Campos, 1993).

\subsection{Fauna}

A fauna é bastante diversificada, tanto em espécies representantes do cerrado como da região amazônica, dos quais destacam-se vários animais ameaçados de extinção, pela ação antrópica, como a onça-pintada (Panthera onca), a anta (Tapirus terrestris), a lontra (Lutra $s p$ ) a ariranha (Pteronura brasiliensis), o tatúcanastra (Priodontes maximus), macaco-aranha (Ateles belzebuth chanek), o barrigudo-cinzento (Lagotrix lagotricha cana), o sagui-de-santarém (Callithrix humenifer intermedius); além de uma ictiofauna rica e avifauna variada (Nogueira Neto, 1991; Fonseca et al., 1994). 


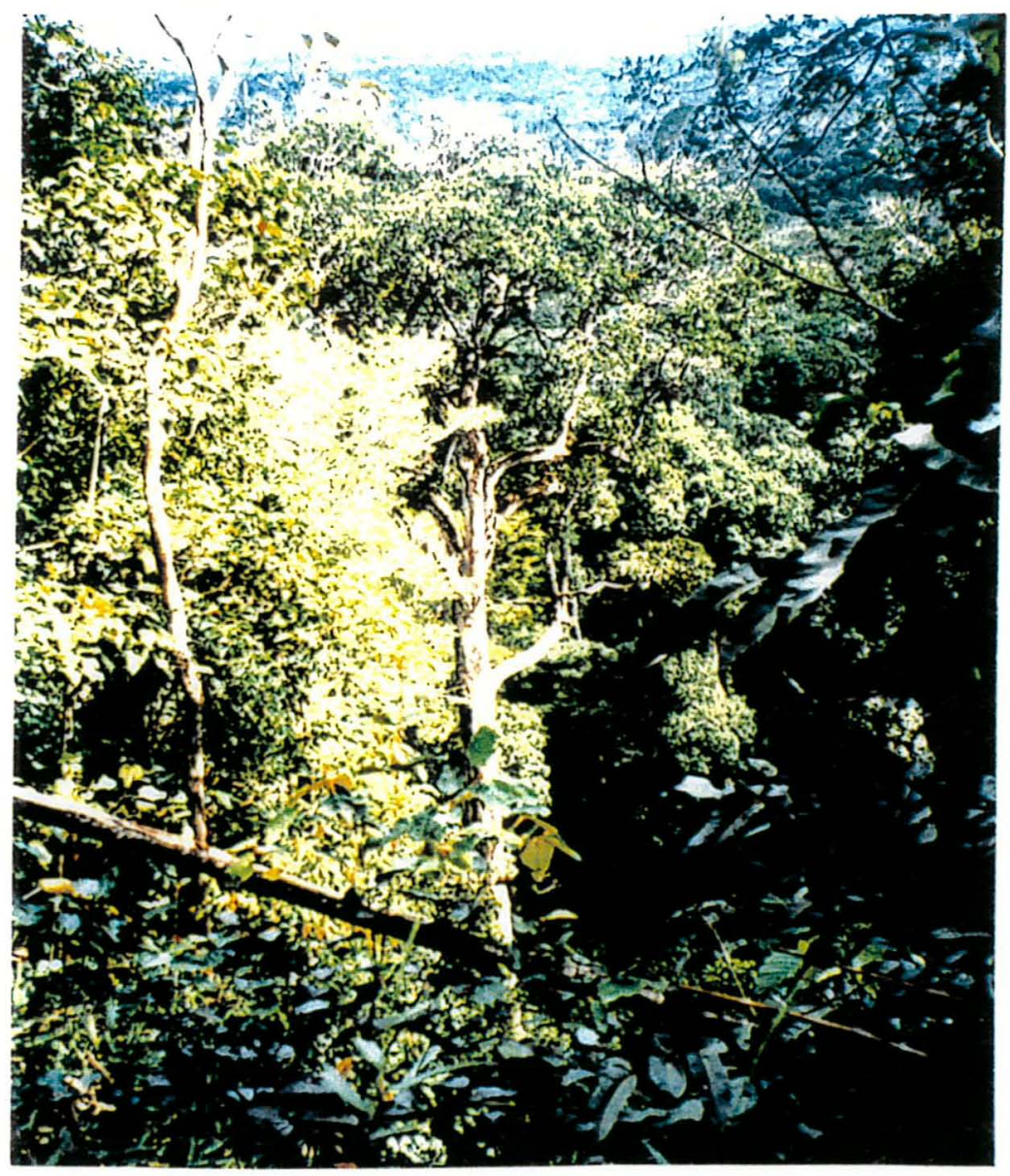

Figura 09 - Aspecto da vegetação próxima aos "Três Morros".

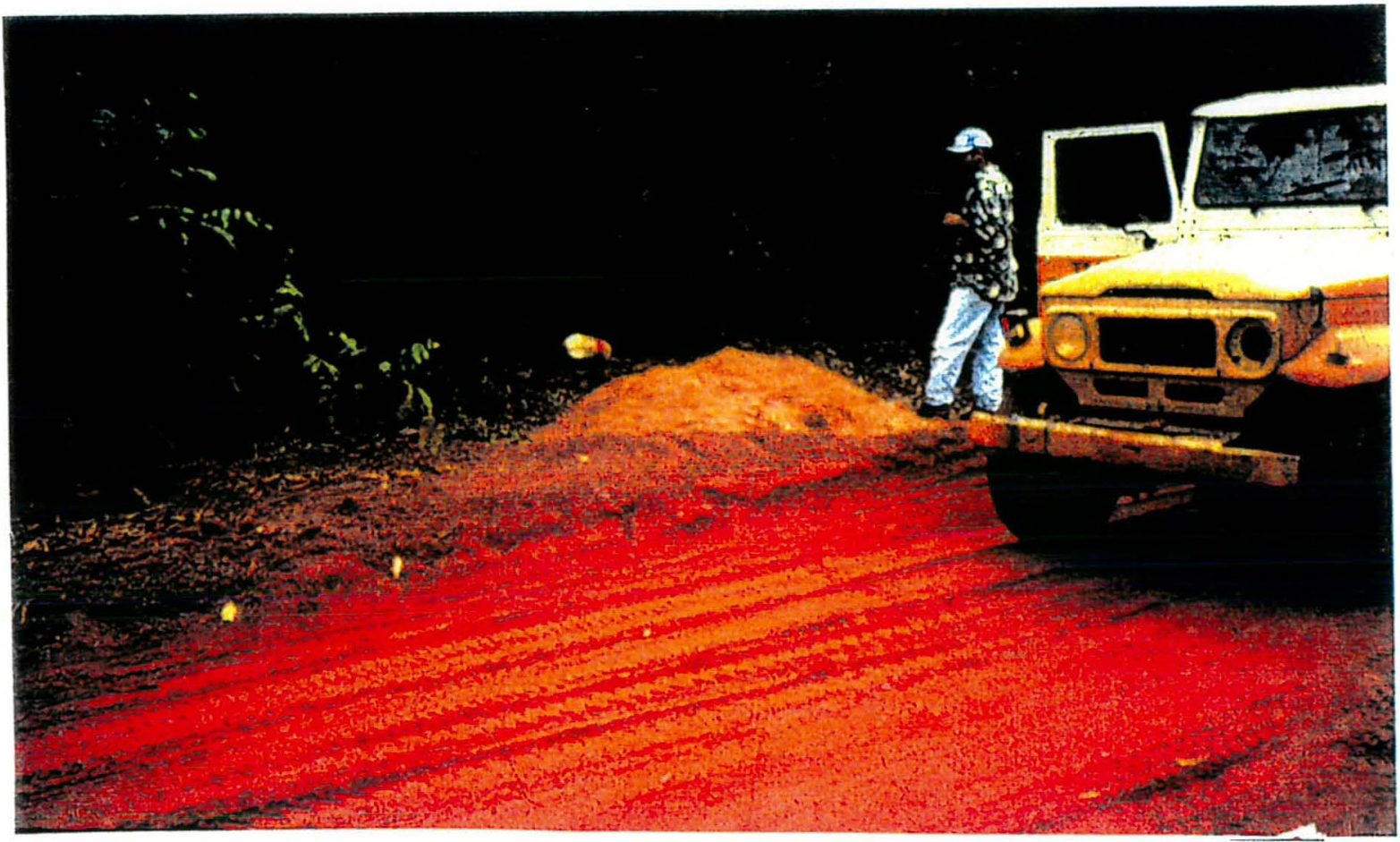

Figura 10 - Toca de tatú-canastra á beira da rodovia AR-1. 


\section{I.3. Características Sócio-Econômicas e Culturais}

\section{I.3.1. Situação Fundiária}

Conforme o descrito no histórico de criação, a Unidade não possui invasores, estando 100\% regularizada. Porém conforme termo 001/88, ficou acordada a perambulação dos índios na Estação.

\section{I.3.2. Uso da Estação Ecológica}

A Estação Ecológica lquê-Juruena não possui Plano de Manejo elaborado e são desenvolvidas muitas formas de uso incompativeis com sua categoria de manejo, prevalecendo alguns usos indevidos, como:

(i) Impacto do garimpo de diamante que ocorre nos limites da Estação, junto ao Posto de fiscalização no Rio 21 de Abril.

(ii) Impacto da retirada de cascalho dentro da área da Estação para correções na rodovia AR-1 ou MT-319, que conecta-se com a BR 364 em Vilhena (RO), estrada de terra batida e tráfego permanente. No período chuvoso recebe o impacto direto das chuvas, ocasionando sempre voçorocamentos e para a realização desses consertos, ocorre a retirada do material. Para tal são abertas "estradas" dentro da mata e em locais com declive superior a $45^{\circ}$, provocando verdadeiras "feridas" dentro da Estação.

(iii) Aumento do efeito de borda, realizado pela abertura dos chamados "bigodes", para escoamento das águas, no perímetro da Rodovia, que faz limite com a Estação, ocorrendo vários alagamentos, uma vez que a água se mistura com o material arenoso e argiloso, formando uma camada de lama, dificultando e às vezes impedindo o tráfego. 


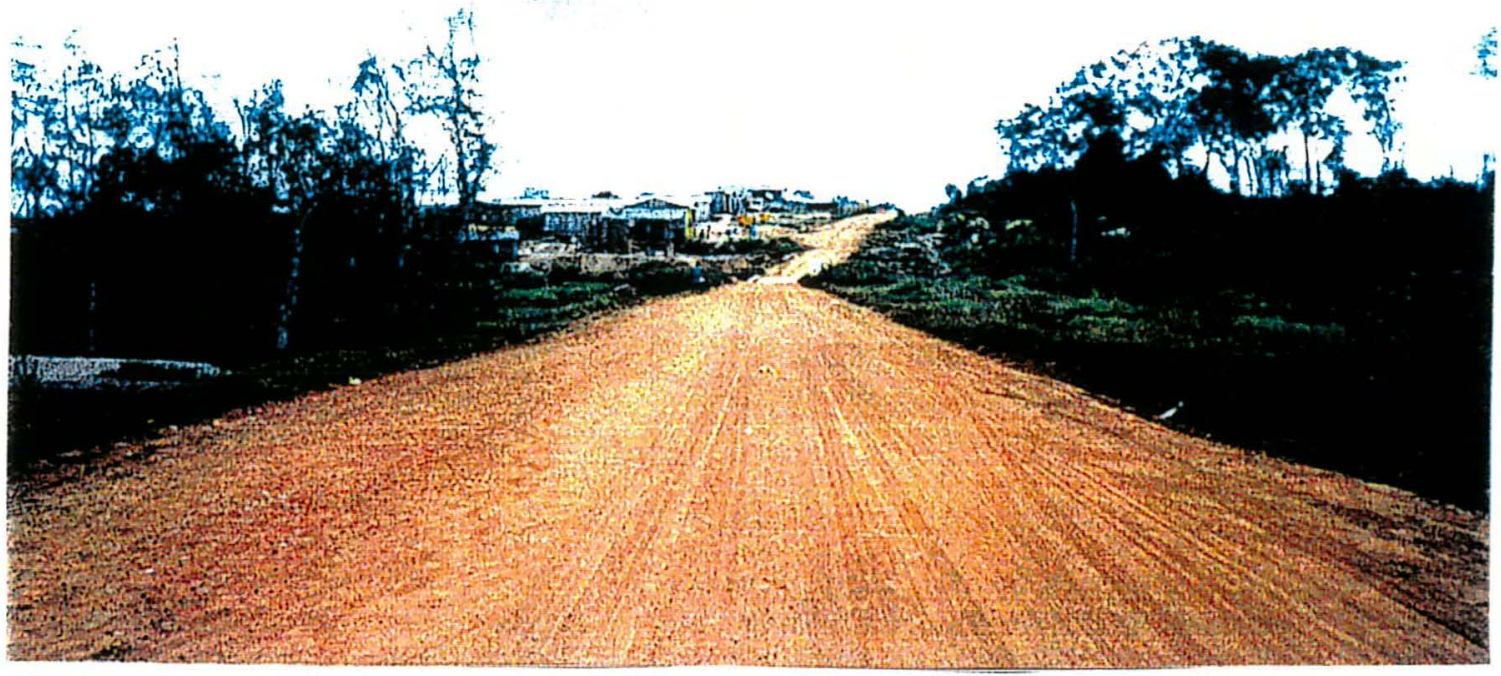

Figura 11 - Garimpo limítrofe á Estação no Rio 21 de Abril, rodovia AR-1.

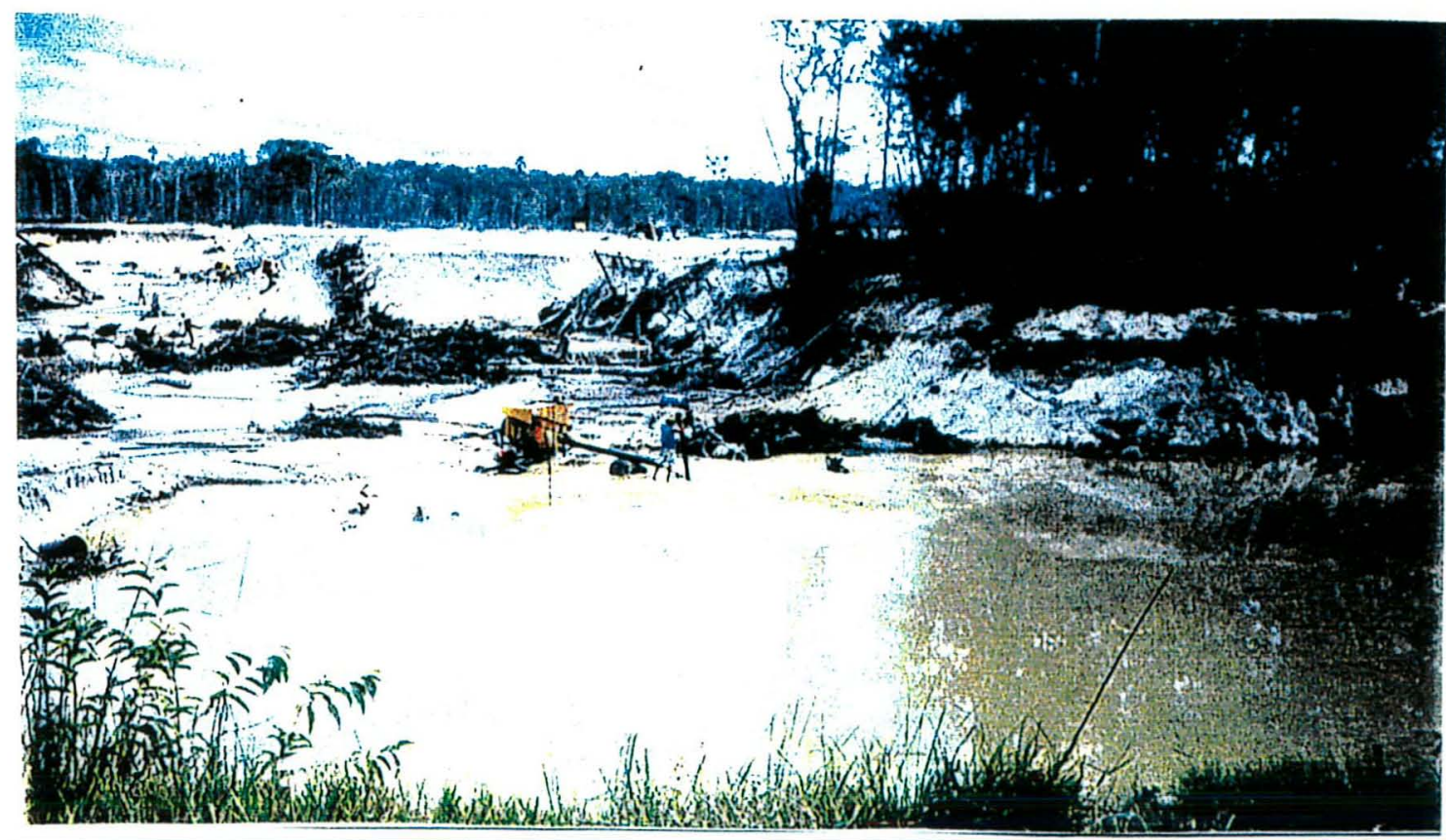

Figura 12 - Aspecto geral do garimpo próximo á estação. 


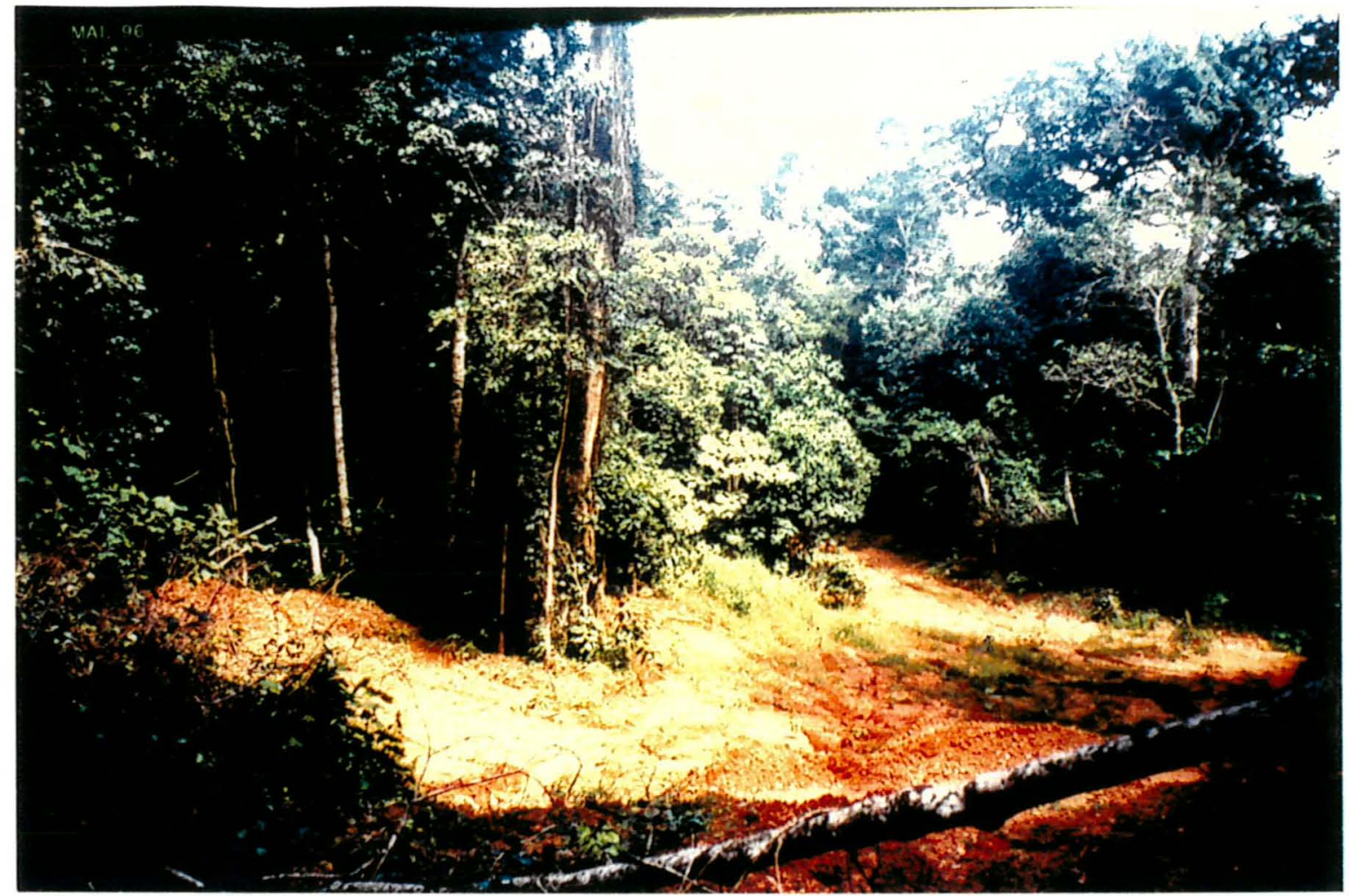

Figura 13 - Desmatamento causado pela entrada de máquinas para a retirada de cascalho na trilha próximo aos "Três Morros".

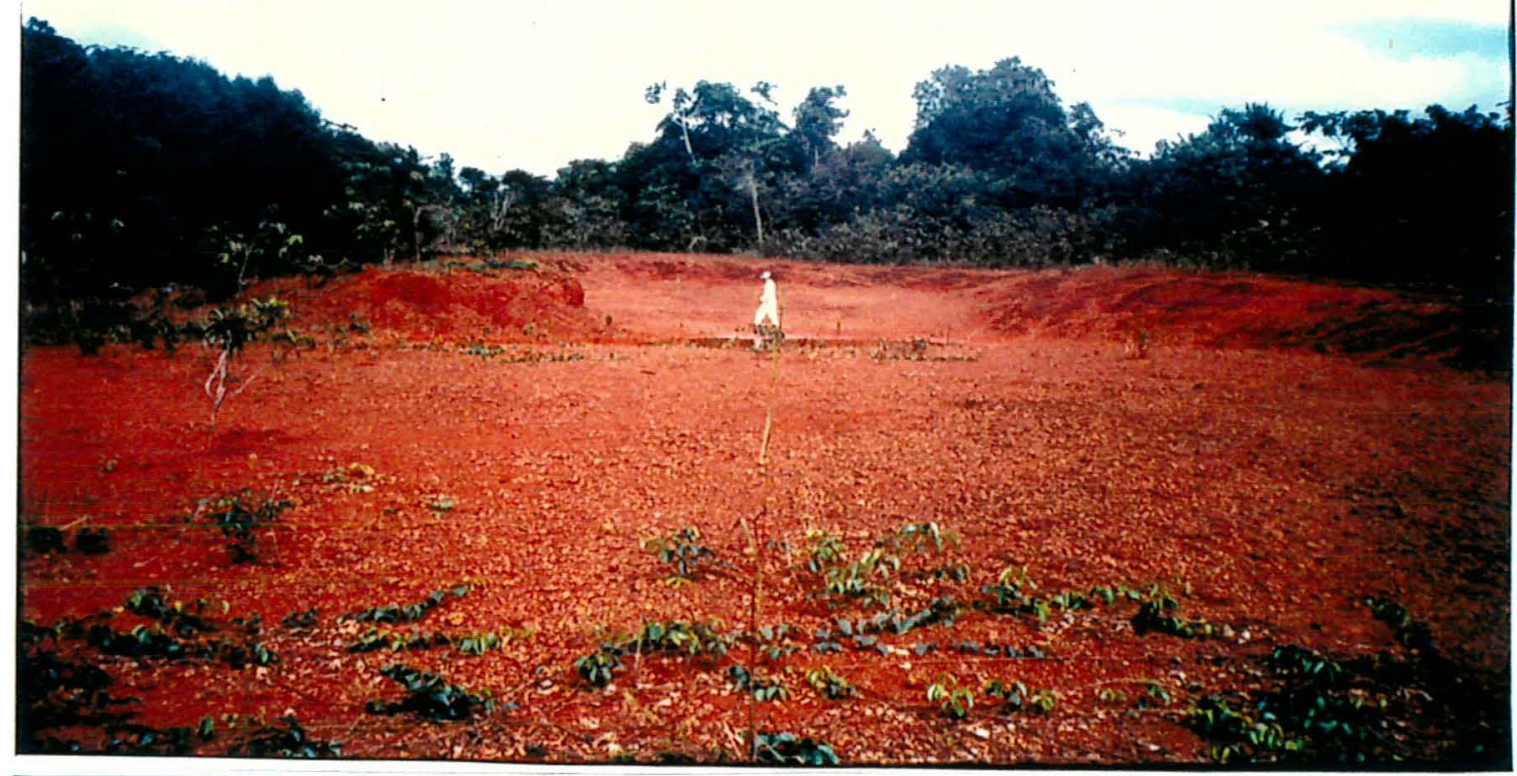

Figura 14 - Local de retirada do cascalho na cota de maior altitude, final da trilha dos "Três Morros". 


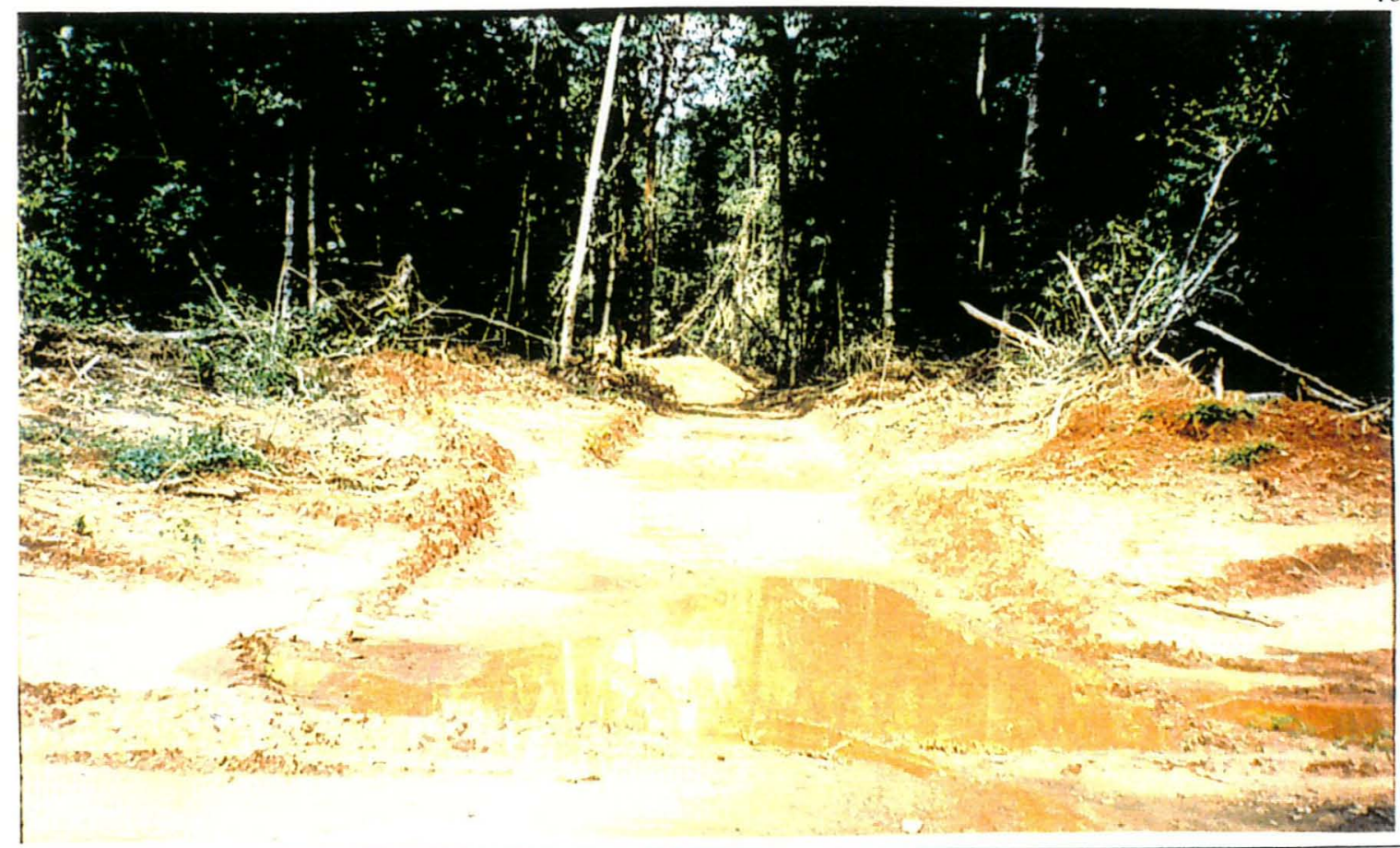

Figura 15 - "Bigode" que adentra a Estação realizado na rodovia MT-319.

\section{I.3.3. Histórico de Ocupação da Região}

A primeira notícia da penetração do branco na região, vem do ano de 1742, quando Leonardo Vieira, desceu o rio Juína e prosseguiu viagem pelo Juruena abaixo, até o Estado do Pará (Barcelos \& Busatto, 1987).

No início do século $X X$, a maior parte dos grupos indígenas da região, não havia sido atingida pelas frentes expansionistas da sociedade brasileira. Levas de seringueiros cearenses, e peruanos se espraiavam pela Amazônia, e subiram poucos anos depois os afluentes do Rio Madeira (Barcelos \& Busatto, 1987).

Foi com a Comissão de Linhas Telegráficas Estratégicas de Mato Grosso ao Amazonas (conhecida por Comissão Rondon) em 1907, por ato do Presidente da República, Afonso Pena, que se desencadeou a ocupação sistemática e permanente do noroeste do imenso Estado de Mato Grosso, que além de estender o telégrafo, abrir estradas estratégicas, executar trabalhos geográficos, botânicos e mineralógicos, também encarregou-se de "pacificar" as populações indígenas em seu percurso (Barcelos \& Busatto, 1987).

Os primeiros contatos nem sempre pacíficos, entre os índios que viviam na região, deram-se em torno das estações telegráficas de Vilhena, José Bonifácio, 
Barão de Melgaço e Pimenta Bueno, inauguradas pela Comissão entre 1912 e 1915, quando toda a linha de Cuiabá a Santo Antônio do Madeira entrou em funcionamento (Barcelos \& Busatto, 1987).

Surgiram núcleos, vilas e seringais ao longo da linha telegráfica, não alcançando de imediato as nações indígenas. Mas com o passar dos anos ocorreram eventuais encontros entre índios e seringueiros, castanheiros ou caçadores de pele, e consequentemente as hostilidades se estabeleceram.

As primeiras informações mais precisas sobre os indios dessa região os Enawenê-Nawê, se devem a Aires Cabral (1818), Rondon (1909) e Roquete Pinto (1917), povo de língua Aruak que habita a região do Rio Juruena à Serra do Norte, de acordo com citações etnográficas, cujas referências mais remotas datam do século XVII (Barcelos \& Busatto, 1987).

O Município de Juína, (que significa "Rainha da Floresta") porção desmembrada do território de Aripuanã, deve seu nome ao rio Juína-Mirim, que o atravessa no sentido norte-sul, região imemorialmente ocupada por povos indígenas, Cinta Larga e Enawenê-Nawê.

Pelas dificuldades de acesso por terra, a região de Aripuanã, chamada de "terra esquecida", permaneceu isolada do resto do Estado até por volta de 1972 (Ferreira, 1994).

Estes povos indígenas que viviam em relativa tranqüilidade até o final da década de 50 , se viram pressionados e obrigados a recuar em função do avanço dos brancos na região, quando então foi criado o Parque Indígena do Aripuanã em 1969, através do decreto $n^{\circ} 64.860$, para colocar-se os índios Cinta-Larga.

Os projetos do Estado receberam incrementos e incentivos fiscais do governo federal ainda na década de 70. A Lei Estadual 3.307 de 28/12/1972, homologada em 1973, passou as terras devolutas do Estado para a Companhia de Desenvolvimento do Mato Grosso (CODEMAT) para projetos de colonização.

$\mathrm{Na}$ época a área pertencia ao Município de Aripuanã, e segundo consta foi Gabriel Müller, um dos autores, através de Lei aprovada pelo Congresso Nacional por indicação e influência do então Senador Filinto Müller, dando poderes para o Estado de Mato Grosso licitar imensa área, sendo colocadas à venda dois milhões de 
hectares, divididos em dez glebas de 200.000 ha e negociados principalmente com ruralistas do sul do país.

A Prefeitura de Aripuanã foram cedidos 117.000 ha para colonização agrícola às margens do Rio Juruena, tendo como referência a Vila de Fontanillas e 65.000 ha às margens do Rio Aripuanã.

A partir de 1976 interesses econômicos e políticos se conjugaram para desinterditar as áreas reservadas aos índios. Nesse mesmo ano 1976, o Projeto RADAM, detecta a presença de ouro, diamante, cassiterita, ferro, titânio e outros minerais na região de Aripuanã e as terras do Parque são reduzidas em $50 \%$, visto que o Decreto 78.109 de 22 106/76, declarou sem efeito parte da interdição anterior, concedendo apenas pequena extensão de terras à beira do Rio Aripuanã (A.I. Serra Morena), onde se localizava a frente de Atração da FUNAl, deixando vários grupos Cinta-Larga fora de seus limites (Silva, 1987).

O episódio de um verdadeiro leilão de terras em Aripuanã é denunciado, e descobre-se posteriormente que algumas dessas terras tinham donos antigos, e que outras foram vendidas, mais de uma vez (Silva, 1987).

Com os mesmos fins, a FUNAl expedia certidões negativas, apesar da forte evidência de presença indígena em toda a região, permitindo a iniciativa do Projeto Juína de colonização, sob responsabilidade da CODEMAT e da SUDECO (Superintendência do Desenvolvimento do Centro Oeste).

Em 1974 a CODEMAT inicia a abertura da estrada que faria a ligação entre a BR-364, a partir do Município de Vilhena (RO) até a sede do Município de Aripuanã (MT), recebendo o nome de AR-1. No ano seguinte, 1975, foi incluida no programa POLAMAZÓNIA (Programa de Desenvolvimento da Amazônia), passando a constituir-se no principal eixo da malha viária prevista para o Pólo Aripuanã.

Nessa mesma época, terras foram cedidas à empresa de Mineração Sociedade de Pesquisas Minerais (SOPEMI), que iniciou sua atuação na região, no início da construção da estrada (Fundação Júlio Campos, 1993).

A partir dali, vieram para a zona diamantífera, técnicos bem como os garimpeiros tendo que abrir "picadas" na mata, pois apenas existiam os caminhos abertos pelos indios, o que comprovava sua existência na região. 
Em 1976, os trabalhos para a construção da AR-1, estavam a todo vapor, salvo nos períodos chuvosos, época em que o manejo de máquinas e equipamentos fica comprometido, graças ao perene lamaçal, e atoleiros causados pelas constantes chuvas.

A partir do início da derrubada da mata por onde passaria o leito da estrada, determinou-se que o primeiro acampamento seria no $\mathrm{km} 60$, porém foi no $\mathrm{Km}$ 180, que o acampamento perdurou por mais tempo. Ficando a CODEMAT responsável pela construção da estrada.

Efetivamente a partir de 1978, começava a história da colonização do Municipio de Juína com a vinda de muitas famílias, principalmente do sul do país, entre os quais, gaúchos, paranaenses, catarinenses, paulistas e mineiros. Obviamente, o fato de ser Juína extremamente rica em diamantes, atraiu pessoas das mais diferentes localidades.

O contato mais efetivo dos índios Salumã com a nossa sociedade aconteceu recentemente, em 1974, através dos padres da Missão Anchieta.

Somente em 1983, após alguns anos de convivência com esses índios, é que os padres descobriram a sua autodenominação Enawenê-Nawê, (que em sua língua significa algo como "os que possuem espírito"), impropriamente conhecidos por Salumã, apenas um nome masculino (Barcelos \& Busatto, 1987).

\subsection{Dados culturais Enawenê-Nawê}

Os Enaunê-Nauê não falam português e sua cultura tradicional permanece intacta, não apresentando nenhum grau de dependência da sociedade nacional, a não ser no que se refere à garantia de seu território e à defesa contra as doenças introduzidas pela população envolvente.

Estão adaptados tradicionalmente ao seu ecossistema, numa região de transição, campo-cerrado, e floresta, onde predominam as matas ciliares que protegem os cursos d'água" formadores do Juruena. São um povo de exímios pescadores, utilizando-se principalmente do timbó e técnicas de barragens. Usavam também anzóis com fios subtraídos da linha telegráfica construída por Rondon. 
Sendo a pesca a sua fonte quase exclusiva de proteína animal, já que se recusavam a comer carne de caça, sua economia está assentada na exploração intensiva de todos os cursos fluviais de seu território tradicional.

Sua sociedade mantém uma singular organização social, repartindo-se em grupos clânicos e núcleos familiares distribuídos em várias aldeias. A aldeia central, está hoje situada à margem esquerda do Rio lquê, local onde o grupo como um todo reúne-se para os períodicos rituais, que ocupam parte considerável do ciclo anual de atividades.

Ainda que as roças da aldeia central sejam bem maiores, pois precisam sustentar a população inteira durante as festividades, todas as aldeias possuem roças próprias, onde se destacam algumas espécies de milho, mandioca e feijão.

Ocupam uma área efetiva que se estende do rio Preto ao Norte, à reserva Nambikwara ao Sul, Rios Sapezal e Papagaio à Leste, e Rio Doze de Outubro à Oeste. Esta extensa área é indispensável à sua sobrevivência, pois dela dependem para o exercício de sua agricultura, da pesca intensiva, coleta de frutos, mel, raízes e diversos utilitários de consumo alimentar e medicinal.

Atualmente vivem em uma aldeia principal e várias aldeias secundárias, dispersas ao longo de seu território, preservando intensamente sua cultura.

Essa distribuição rotativa e extensa de aldeias deve-se principalmente, à pobreza do solo da região, que impele o grupo, a contínuos deslocamentos para tirarem o melhor proveito possivel de suas roças. Como não consomem caça, também deslocam-se intensamente por todos os rios e afluentes da região em grandes pescarias coletivas, sendo o peixe a base protéica de sua alimentação.

Contatados em 1974 por membros da Missão Anchieta, contavam com uma população de cem pessoas. Desde 1977 tem recebido assistência médica e acompanhamento permanente por parte da Missão Anchieta / OPAN.

Têm consciência dos limites de suas terras, que thes são sagradas em todos os sentidos, e da necessidade de defendê-las a todo custo. Incidentes graves ocorreram em 1984, cujo saldo foram mortes trágicas que poderiam ter sido evitadas se houvesse uma demarcação efetiva e vigilância por parte das autoridades, desde a época do contato, na região conhecida por "Área Indígena Salumã". 
Dificilmente se afastam do seu território, sobre o qual detêm domínio absoluto, permanecendo atentos aos movimentos dos "civilizados" que os cercam deixando claro em suas represálias, que sempre defenderão o território que thes pertence secularmente, muito antes da chegada do homem branco.

Segundo Seilert (1995), o grupo é constituído por 245 individuos, encontrando, sua área demarcada, conforme Portaria Ministerial $n^{0}$ 04/91 no segundo semestre do ano de 1994, quando se procedeu a desintrusão de alguns núcleos de posseiros ali existentes.

Atualmente existem apenas dois pontos problemáticos, 0 reduto ocupado pelo posseiro conhecido como Sr. Luiz, na localidade denominada Roda D'água (segundo informações no local, soube-se que os índios toleram sua presença e do seu hotel, desde que, não desmate mais, além do que havia antes, para suas roças ) e, o segundo, um garimpo situado às margens da Rodovia MT-319, Km 80, nos limites da área indígena com a Estação Ecológica lquê-Juruena.

Com uma base sócio-econômica equilibrada, lutam pela sustentação de um modelo que lhes garantiu até aqui considerável autonomia.

São conscientes dos riscos que thes representam 0 avanço desordenado das frentes de exploração circunvizinhas; os Enawenê-Nawê começaram, já há vários anos, a se preocupar com a vigilância das fronteiras de suas terras. Mais recentemente, essa preocupação tem levado o povo a encontrar formas próprias de vigiar suas fronteiras e uma delas tem sido a associação da fiscalização com as atividades tradicionais (Seilert, 1995).

\subsection{Definição Territorial}

Em 1978, a Missão Anchieta apresentou à FUNAl uma proposta para interdição da Área indígena Salumã.

Nesse mesmo ano o Governo do Estado de Mato Grosso doou à União uma área de 266.000 ha para a instalação da Estação Ecológica de lquê, da SEMA, através do decreto $n^{\circ} 1452$ de 01.08 .78 . Essa área sobrepunha-se em grande parte ao território tradicional dos índios. 
Em 22 de outubro de 1979, através de portaria $n^{\circ}$ 630/E, foi designado um Grupo de Trabalho com vistas a definir os limites da AI Salumã.

Em 1980, a Missão Anchieta apresentava nova proposta para interdição, abrangendo a área de 690.000 ha aproximadamente, incluindo sítios de cultivo até então desconhecidos, e, portanto, não constantes na proposta anterior.

A precariedade dos conhecimentos até então existentes sobre os Enawenê-Nawê e sua efetiva ocupação territorial faziam retardar uma solução definitiva quanto à delimitação da área.

Em setembro de 1984, houve um episódio do massacre dos não-índios, e um terceiro GT foi instituído pela Portaria n 1766/E, de 19/09/84 com a participação de representantes da FUNAI, Missão Anchieta, SEMA, INCRA, INTERMAT (Instituto de Terras do Mato Grosso) e PUC/SP.

Em todas as ocasiōes, as equipes foram acompanhadas por membros da Missão Anchieta, com o objetivo de obter dados históricos e etnográficos necessários, posto ser a bibliografia sobre o grupo bastante restrita.

Por outro lado, a prolongada convivência com o grupo e o aprendizado da língua, veio permitir que um padre, membro da Missão Anchieta, finalmente traduzisse com precisão a definição de seu território tradicional, e que desejavam ver demarcado e respeitado.

Inicialmente, os entraves a uma definição da área indígena prendiam-se à criação da Estação Ecológica lquê, no território indígena, uma vez que não se registrava ocupação efetiva de não índios na região.

As propostas conciliatórias que foram aventadas não se concretizaram. A última delas, a Portaria 1776/E de 19.09.84 não se viabilizou porque a SEMA, mostrou desinteresse em manter um cinturão ecológico protetor, então sugerido, em torno da área indígena.

Com a evolução das negociações entre FUNAI e SEMA, viabilizou-se uma solução através da assinatura de um convênio, cuja cláusula primeira - do objeto rezava o seguinte:

"O presente instrumento tem por objeto o estabelecimento da colaboração mútua e recíproca entre as partes para a execução de um programa de proteção da área da Estação Ecológica de lquê, criado pelo decreto $n^{\circ} 88.061$, de 
02.06.81 doravante denominada ÁREA ECOLÓGICA DE INTERESSE INDÍGENA AE II, situada no Município de Aripuanã, no Estado de Mato Grosso, tendo em vista a superposição de sua área com a do territónio Enauwê-Nawê".

Enfatizando ainda a baixa fertilidade do solo naquela região, a necessidade da preservação do sistema hídrico e a preocupação dos índios na garantia do seu território, cujos limites demostram conhecer pormenorizadamente, a FUNAI recomendava urgência na regularização da mesma para a garantia da sobrevivência física e cultural do grupo indígena Enawenê-Nawê.

Essa área abrange na realidade 752.000 ha, com perímetro aproximado de $700 \mathrm{~km}$, incluindo-se os 266.000 ha da Estação Ecológica de Interesse Indígena, de conformidade com o mapa e memorial descritivo, elaborados pelo setor competente da FUNAI, interpretando o resultado dos estudos transcritos no Processo FUNAI/BSB/0292/78.

A área Indigena Salumã estava situada na região de influência do POLONOROESTE (Programa Integrado de Desenvolvimento do Noroeste do Brasil) e sua regularização fez parte dos compromissos assumidos pelo governo brasileiro. Parecer 168/87 assinado pelo FUNAI, MINTER, MIRAD, SG/CSN., em 05 de junho de 1987.

\section{I.3.4. Aspectos Culturais}

Achados de peças fósseis de animais extintos, através da ação garimpeira são fatos comuns na região. Normalmente esses objetos são desenterrados e novamente soterrados, quando não, destruidos. Também são encontrados potes de cerâmica, muitas vezes intactos, porém muitas vezes quebrados na ânsia, de se encontrar algo de valor no seu interior.

Casos existem em que os garimpeiros os guardam por curiosidade, mas outros simplesmente alegam má sorte com a guarda desses objetos.

Foram encontrados fósseis, na Fazenda São Luiz, destacando-se um grande dente com $20 \mathrm{~cm}$ de altura por $10 \mathrm{~cm}$ de largura, enterrado a 6 metros de profundidade, identificado pela paleontóloga Susana Hiroka (IPECA, Instituto de 
Pesquisas Currupira Arara, sediado em Cuiabá), como pertencente a mastodonte da espécie Haplomastodon waringi² (Fundação Júlio Campos, 1993).

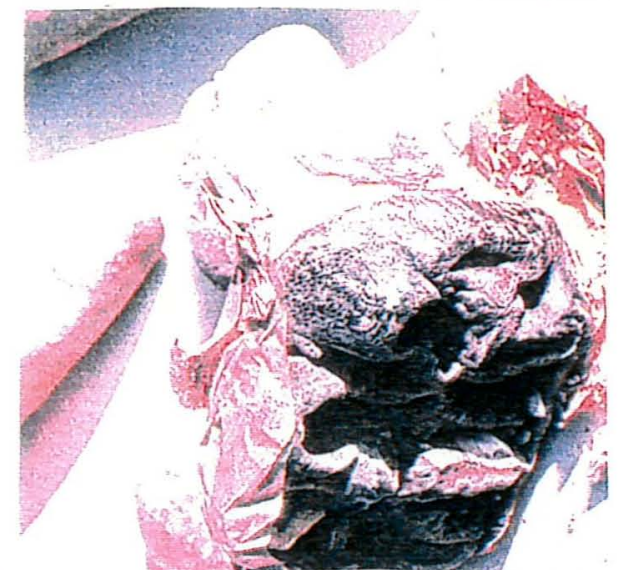

Figura 16 - Dente de Mastodonte encontrado enterrado a $6 \mathrm{~m}$ de profundidade com aproximadamente $20 \mathrm{~cm}$ de altura por $10 \mathrm{~cm}$ de largura.

\section{I.4. Área de Influência da Estação Ecológica- ESEC}

O entorno imediato da Estação é ocupado em parte (cerca de 10\%) por fazendas, dedicadas a pecuária, que se utilizam do desmate e da queima muitas vezes de maneira indiscriminada abrangendo inclusive as áreas de cabeceiras de rios, e a inobservância da declividade do terreno, desencadeando processos erosivos. O desperdício de madeiras, muitas delas de excelente qualidade, que são totalmente deixadas de lado ou queimadas logo após a derrubada, com a finalidade da formação de pastagens (Figura 17).

Com limite norte a Rodovia não pavimentada AR-1 ou MT-319, possibilita a interligação de Juína (MT) a Vilhena (RO) e à BR 364, apresenta sérias dificuldades de tráfego, principalmente na estação chuvosa, quando praticamente fica intransitável, prejudicando o escoamento de produtos e o abastecimento local, realizado por carretas e caminhões, que em geral levam os produtos "in natura" e retornam com os manufaturados. Para o transporte de passageiros, opera uma empresa de ônibus no percurso Juina a Vilhena.

\footnotetext{
${ }^{2}$ Existe comprovação científica da presença de mastodontes (elefantes) na América do Sul, onde está incluso o Estado de Mato Grosso. Viveram a 38 milhões de anos atrás e se extinguiram entre 5.000 e 10.000 anos atrás.
} 
A noroeste a Estação limita-se com o Parque Indígena do Aripuanã; ao Sul faz limite com a Área Indígena Enawenê Nawê. E a leste com o garimpo do "Km 180", no Rio 21 de Abril, garimpo este, que utiliza formas de exploração rudimentar, manual, semi-mecanizada e mecanizada. A população garimpeira que varia de 20 (nas chuvas) a 200 pessoas, convive com um alto índice de malária. Ocorre também, o extrativismo vegetal em áreas limítrofes à Unidade, com mais intensidade sob madeiras nobres como a cerejeira (Amburana acreana) e o mogno (Swietenia macrophyla). Porém com sua escassez devido intensa exploração, faz com que o setor madereiro explore também as chamadas madeiras brancas, como a peroba (Aspidosperma spp.), o cambará (Vochysia sp.), o angelim (Dinizia sp.), entre outras espécies.

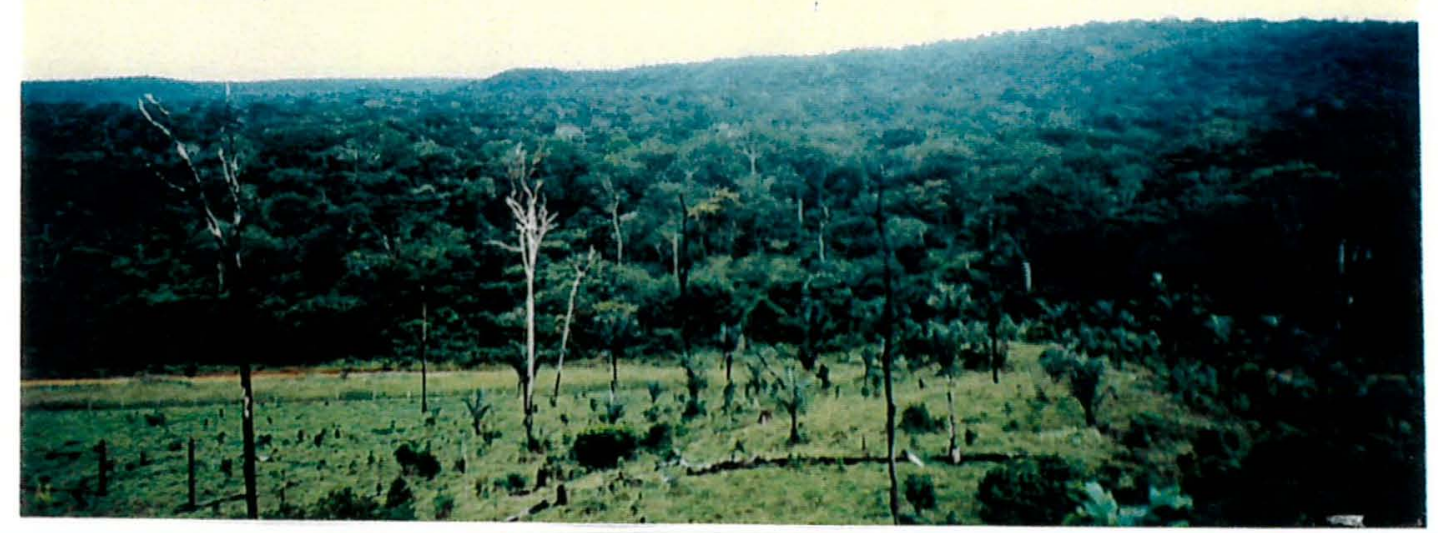

Figura 17 - Aspecto do entorno da Estação (ao fundo), com ocupação agropecuária.

\section{I.4.1. O Município de Juína}

A história de Juína começa, efetivamente, em 1978, com a chegada dos primeiros colonos e madereiros sulistas, após a abertura da rodovia AR-1, (início da construção em 1974) ligando Vilhena (RO) a Aripuanã (MT), numa extensão de aproximadamente $550 \mathrm{~km}$.

A partir de 1987, ocorreram alterações na economia de Juína, baseada na agricultura, pecuária e extração de madeiras, em virtude da mineração diamantífera. 
Esse fato atraiu uma grande leva de garimpeiros e compradores de diamantes, provocando uma sensível mudança nos hábitos sociais e modos de produção, havendo um deslocamento da mão-de-obra da agricultura para o garimpo, transformando áreas de cultivo em pastagem (EMPAER, 1996e).

A partir de 1991, a atividade garimpeira, começou a sofrer expressiva queda na produção, o que fez com que a atividade madereira, com fins de exportação para o sul e sudeste, persistisse uma vez que existia desde o inicio do projeto de colonização.

A atividade que mais se expandiu foi a bovinocultura de corte, devido às dificuldades com a agricultura, mesmo tendo um alto custo a formação de pastagens, onde predomina a raça nelore, com um rebanho estimado em torno de 214.000 cabeças (EMPAER, 1996e).

Não é mais prioridade econômica, os plantios chamados das lavouras brancas (arroz, feijão e milho), devido a fatores como baixos preços, as formas rudimentares de exploração e a baixa tecnologia no setor.

Entre as novas alternativas, estão as culturas perenes, como o café, guaraná, frutas tropicais e o reflorestamento (EMPAER, 1996e).

Quanto ao extrativismo mineral, a maior quantidade de diamante encontrado é o industrial, não gerando impostos ao Município, em virtude das saídas ilegais do produto (EMPAER, 1996e).

\subsubsection{Aspectos Institucionais}

\subsubsection{Infra-Estrutura}

Edificações existentes na Estação Ecológica lquê-Juruena:

(1) Sede com $320 \mathrm{~m}^{2}$ de área construída em alvenaria com cobertura de telha de cimento amianto. (Vide figura 18). 


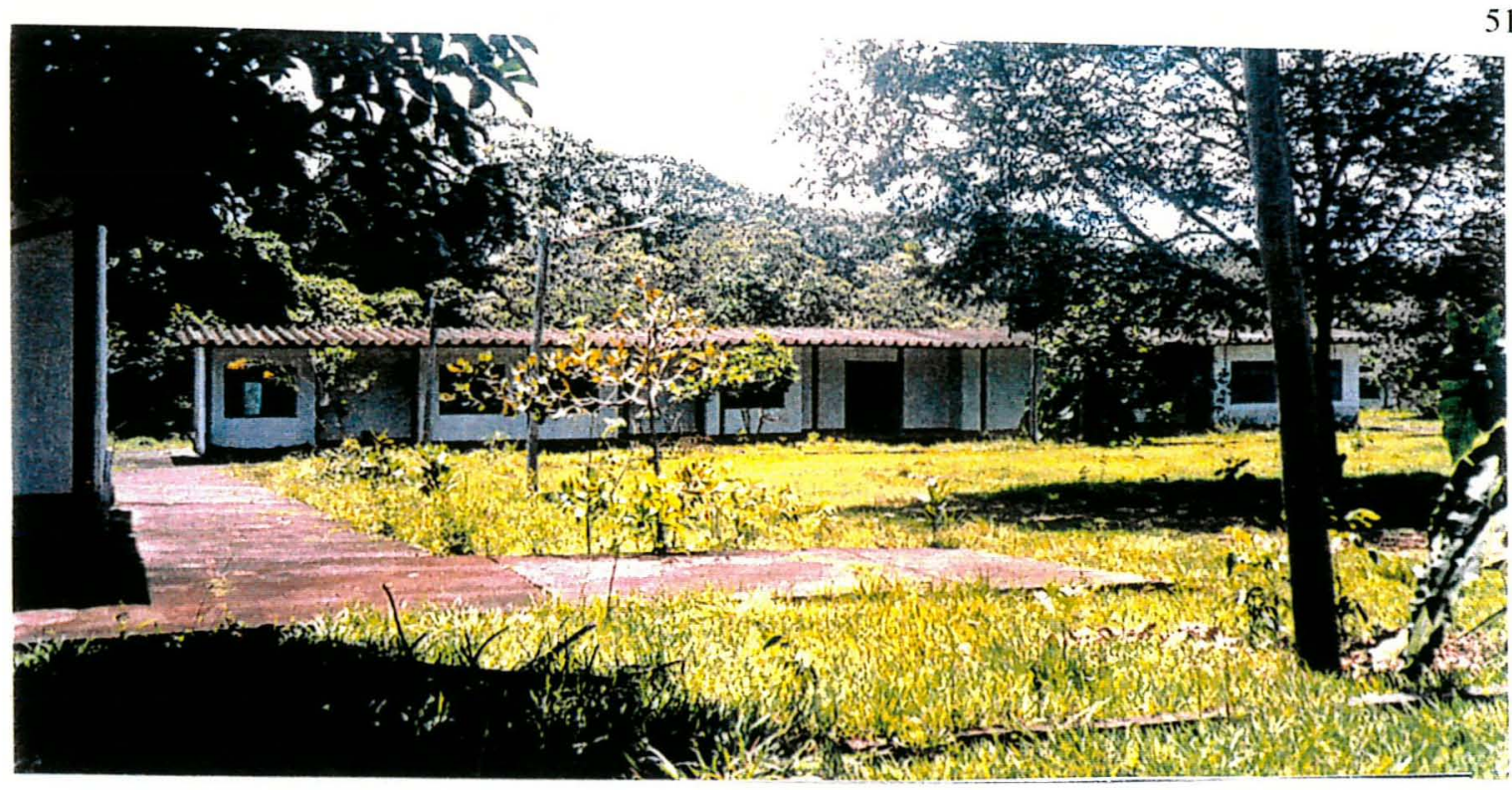

Figura 18 - Aspecto da sede da Estação Ecológica.

(2) Pavilhão auxiliar com $267 \mathrm{~m}^{2}$ de área construída, com cobertura de tellha de cimento amianto, conhecida por "hotel" (Figura 19).

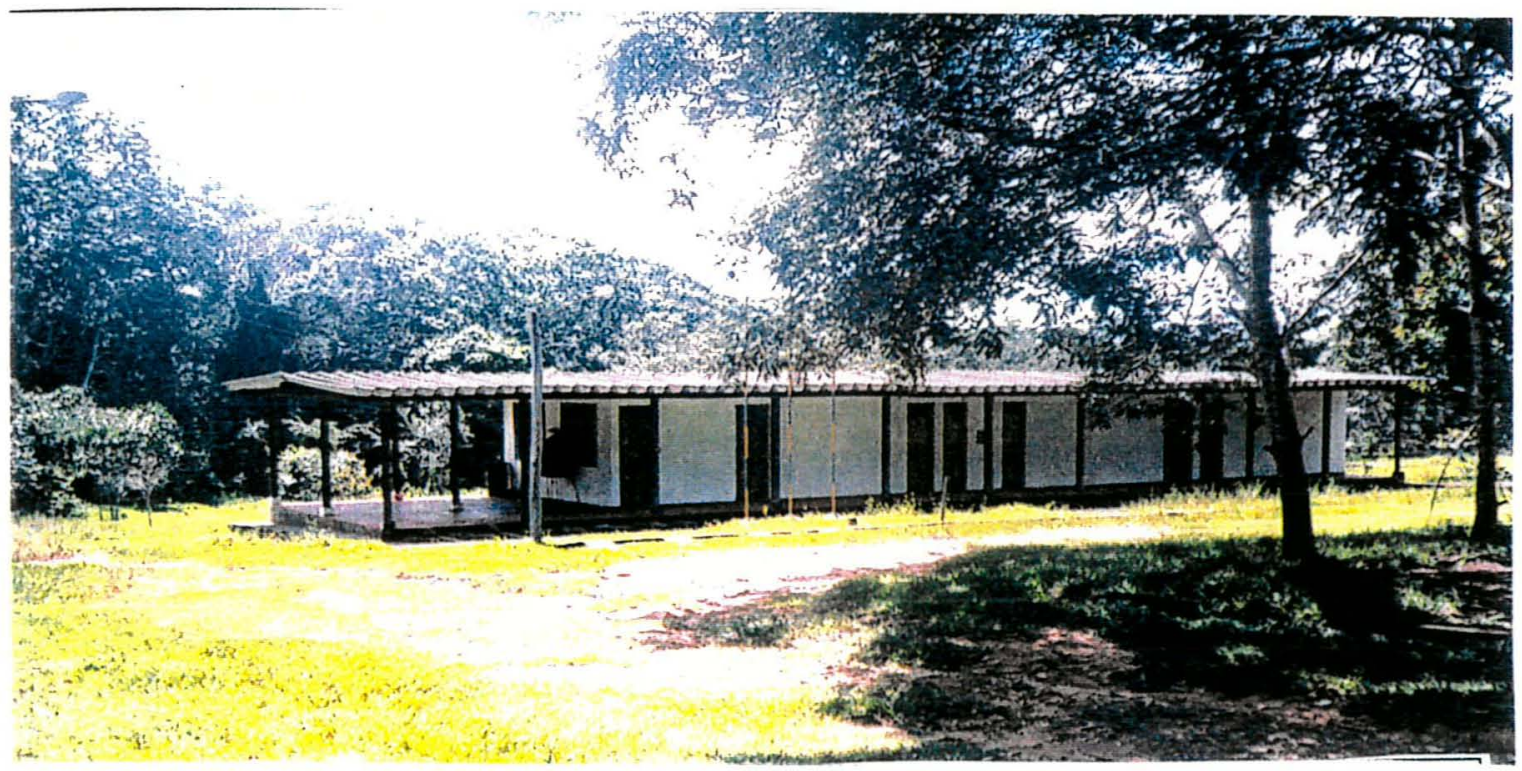

Figura 19 - Construção também conhecida por "Hotel", desocupada.

(3) Casa do Adminstrador com $128,44 \mathrm{~m}^{2}$, também em alvenaria e cobertura de cimento amianto (Figura 20). 


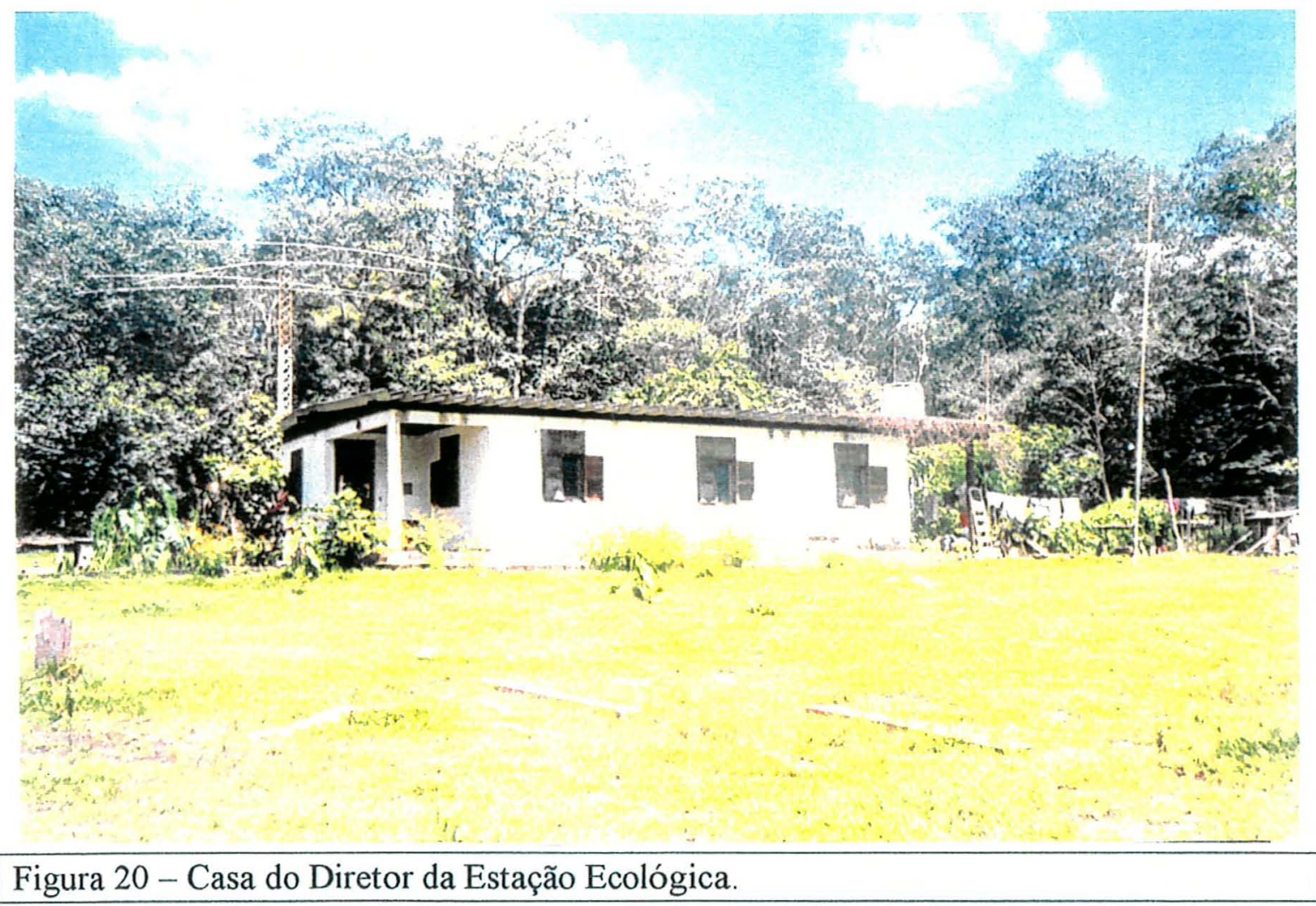

(4) Duas casas de zeladores, construídas com $89,5 \mathrm{~m}^{2}$, cada uma delas. E uma casa do gerador com $6 \mathrm{~m}^{2}$ de área construída (Figura 21).

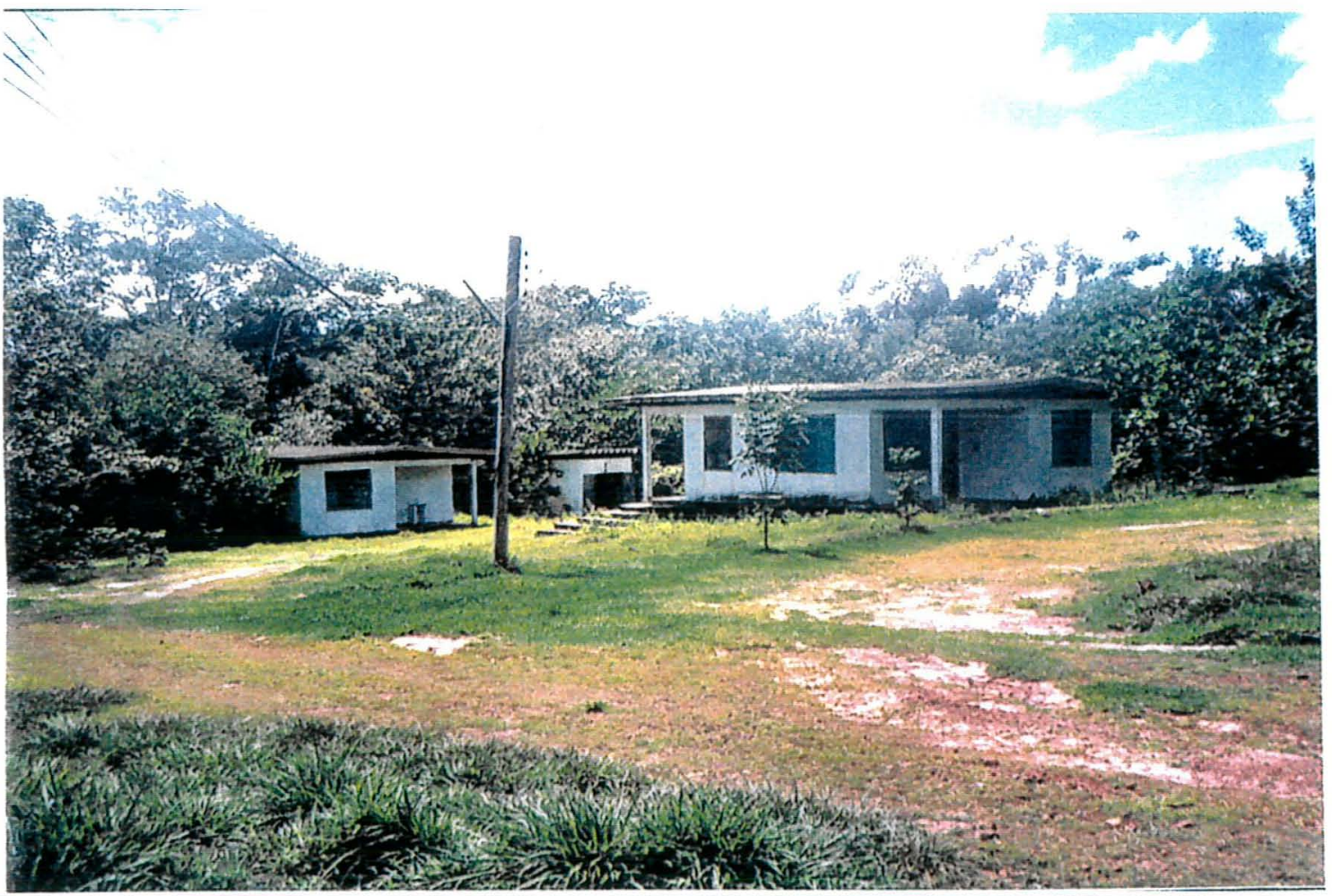

Figura 21 - Casa dos zeladores, ambas desocupadas. 
(5) Campo de pouso, construído com $800 \mathrm{~m}$ de comprimento por $20 \mathrm{~m}$ de largura. Atualmente com $500 \mathrm{~m}$ de comprimento ( Vide figura 06).

Dois postos de fiscalização abandonados, um deles, ao norte da Estação, teve morador por apenas 01 mês, por problemas de falta de água, estando hoje completamente abandonado, como ilustra a figura 22 abaixo:

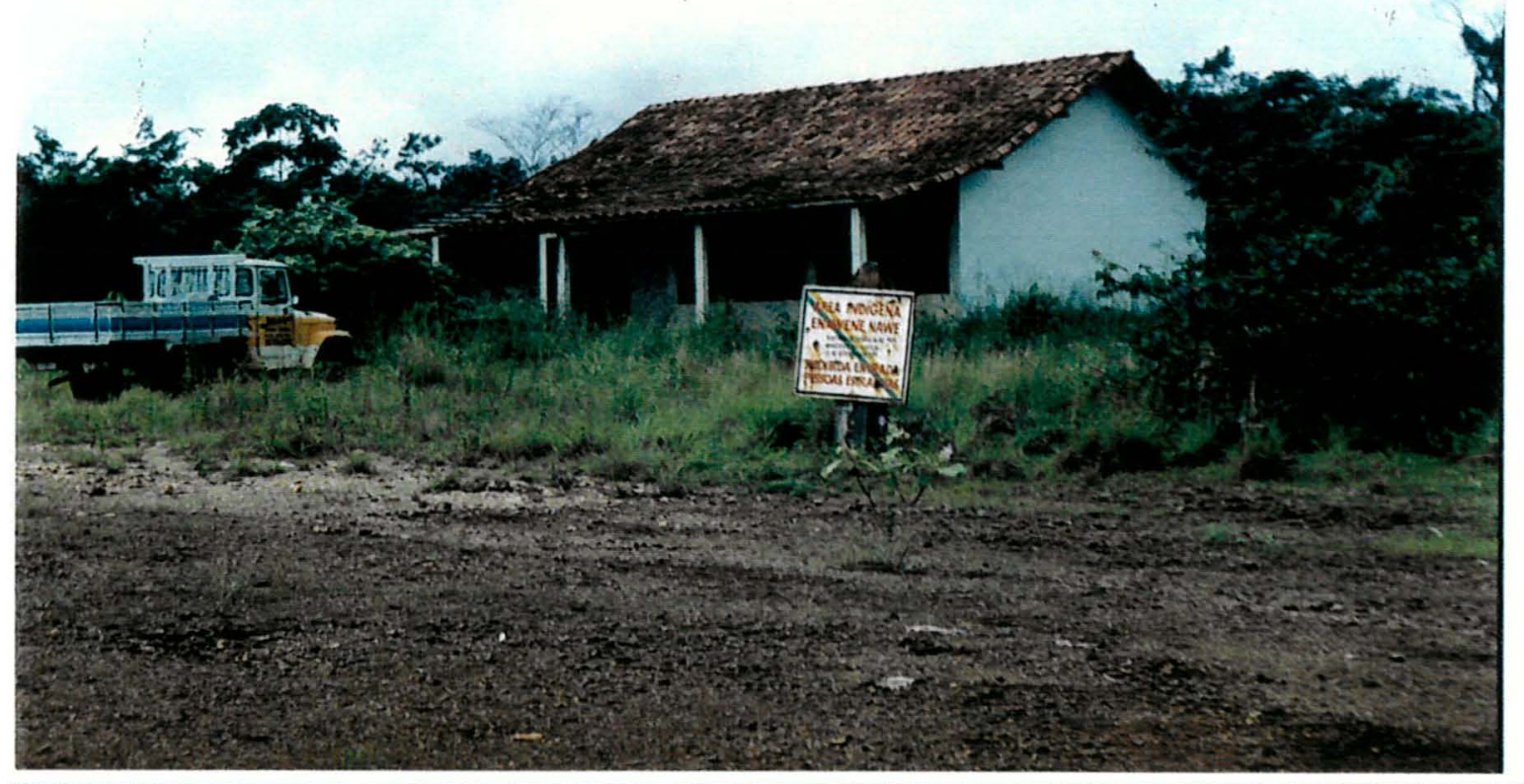

Figura 22 - Aspecto do posto de fiscalização ao norte da Estação, abandonado.

O outro posto, junto ao garimpo, ao sul, encontra-se abandonado desde 1995.

Todas as construções atualmente necessitam de boas reformas, pois a parte em madeira está totalmente comprometida pelo ataque de cupins. A Unidade conta com serviço de rádio comunicação, possuindo um veículo Toyota em bom estado, para as viagens na região. 


\section{I.5.2. Pessoal}

Tabela 02 - Quadro do pessoal da ESEC

\begin{tabular}{|c|c|c|c|c|}
\hline Função/Cargo & Portaria/Nomeação & Ano/nascimento & Escolaridade & Cursos/área \\
\hline 1.Chefe ESEC $\left(^{*}\right)$ & $\begin{array}{c}\text { Portaria } 1586 \text { de } \\
19 / 09 / 96\end{array}$ & 1968 & $\begin{array}{c}\text { Téc. } \\
\text { Agropecuária }\end{array}$ & 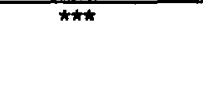 \\
\hline $\begin{array}{l}\text { 2.Aux. Operacional de } \\
\text { Serv. Diversos ** } \\
\text { Chefe Substituto }\end{array}$ & $\begin{array}{l}\text { Portaria } 442 / 93 \\
\text { Portaria } 1760 / 93\end{array}$ & 1962 & $\begin{array}{c}\text { I Grau } \\
\text { incompleto }\end{array}$ & \\
\hline
\end{tabular}

$\left(^{*}\right)$ Não pertence ao quadro do IBAMA, cargo comissionado.

(**) Contratada pela ABES, passando para o quadro regular do IBAMA de acordo com a Portaria $542 / 93$ de 16/04/93.

(**) III Curso de Planejamento e Legislação em Unidade de Conservação. Ilhéus - Bahia. 23/06/1997 à 04/07/1997. Promovido pelo DIREC /IBAMA / PNMA

\subsubsection{Considerações}

O grande empenho nesse resgate histórico e documental sobre a Estação Ecológica de Iquê-Juruena, prende-se ao fato de ser a Unidade de Conservação mais distante da capital e de difícil acesso, e com menos dados disponiveis junto ao órgão gestor.

Somente esta Estação, possui sobreposição com área indígena. $E$ através do Decreto 02/10/96, o Excelentíssimo Senhor Presidente da República revoga justamente o ítem III do Decreto no 86061 de 02/06/81, que criou a Estação Ecológica lquê-Juruena, passando toda a área da Estação Ecológica Iquê-Juruena para a FUNAI, a partir de outubro de 96, fato este, que apesar de inconstitucional, está sendo difícil de ser revisto.

A área de 200.000 ha, que aparenta ser bastante preservada, deve isso justamente ao fato de possuir placas da FUNAI, na área limitrofe da Estação com a Rodovia AR-1, pois a população tem um certo receio desse grupo indígena devido a incidentes ocorridos num passado não muito distante, não obstante é esse fato que garante a defesa solitária da área, uma vez que a Unidade de Conservação conta com apenas 02 funcionários. $\mathrm{Na}$ Estação não existem trilhas 
para monitoramento, a não ser aquelas abertas para retirada ilegal de cascalho ${ }^{3}$, em alguns pontos próximos à Rodovia AR-1.

Deve-se levar em conta que as pesquisas, em face dessa situação sui generis, para serem realizadas deverão estar de comum acordo e anuência entre o IBAMA/FUNAI e ONG's ligadas ao grupo para que não ocorram fatos desagradáveis.

Um dos grandes fatores dificultadores, até pouco tempo atrás era a falta de comunicação da Unidade com a sede em Cuiabá. Atualmente, essa comunicação é realizada diariamente através de rádio, em dois horários das 7:30 às $8: 00$ horas e às $14: 00$ horas. Foram realizadas pequenas reformas, apenas para a manutenção da Unidade.

${ }^{3}$ Este fato foi verificado pela pesquisadora e comunicado a SUPES/MT, através de relatório. 


\section{II. ESTAÇÃO ECOLÓGICA SERRA DAS ARARAS}

\section{Il.1. Situação Histórica e Geográfica}

\section{II.1.1. Localização e Limites}

A Estação Ecológica Serra das Araras foi criada pelo Decreto Federal $\mathrm{n}^{\circ} 87.222$ de 31.05 .82 , com uma área de 28.700 ha, com cerca de $50 \mathrm{~km}$ de comprimento por $8 \mathrm{~km}$ de largura. Inserida em uma área de transição no domínio de cerrado, próximo ao Pantanal mato-grossense e sudoeste do Estado de Mato Grosso, no município de Porto Estrela, (anteriormente englobando terras dos Municipios de Barra do Bugres e Cáceres) entre as latitudes $15^{\circ} 27^{\prime}$ e $15^{\circ} 48^{\prime}$ Sul e longitudes $57^{\circ} 03^{\prime}$ e $57^{\circ} 19^{\prime}$ Oeste, abrangendo trechos localizados nas Serras da Camarinha, Bocaina, Três Ribeirões, Sabão, Serra Grande, Tombador e Pindaivá, pertencentes à unidade geomorfológica denominada Província Serrana, com altitudes variando entre 300 a 800 metros (Figura 24).

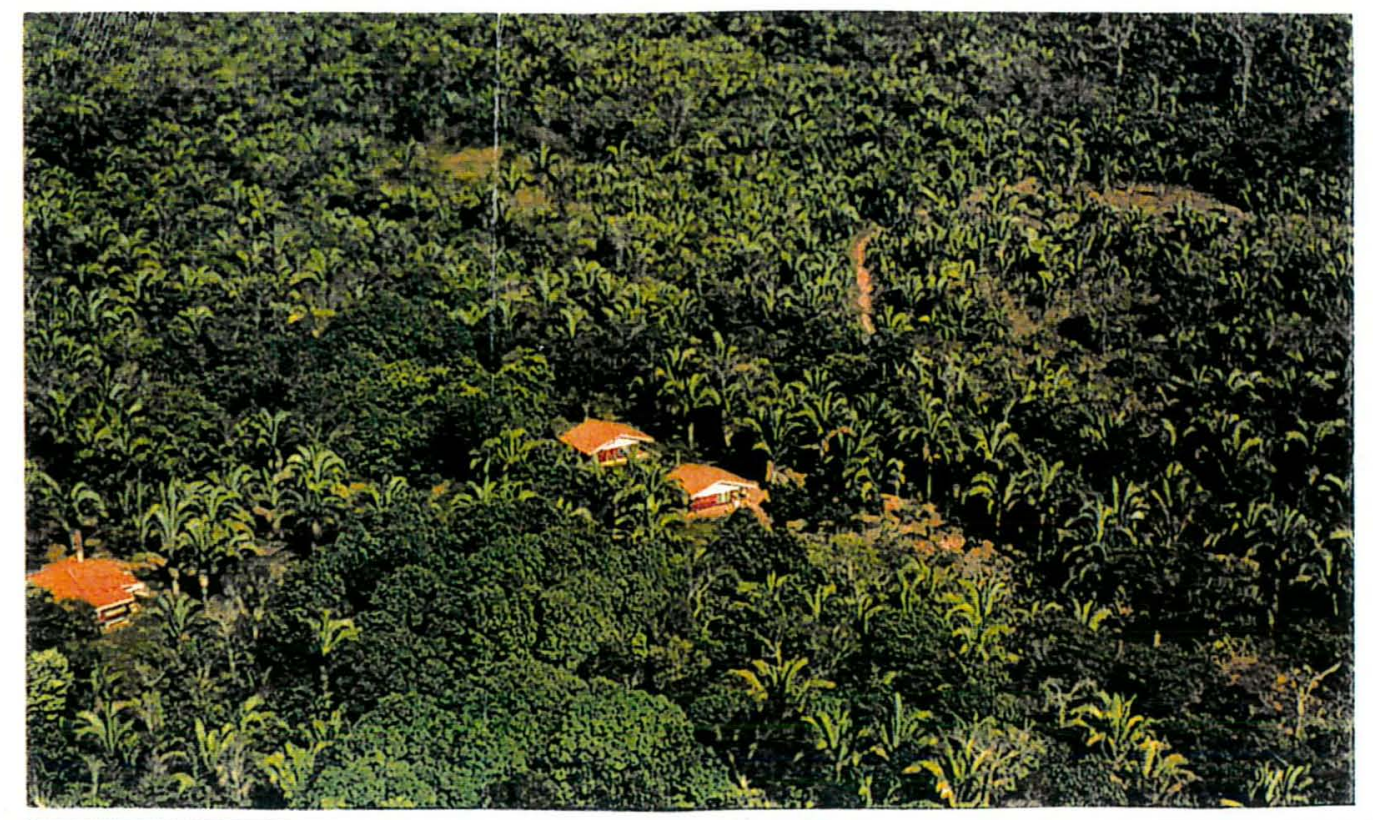

Figura 23 - Aspecto geral da sede da Estação Ecológica Serra das Araras. 


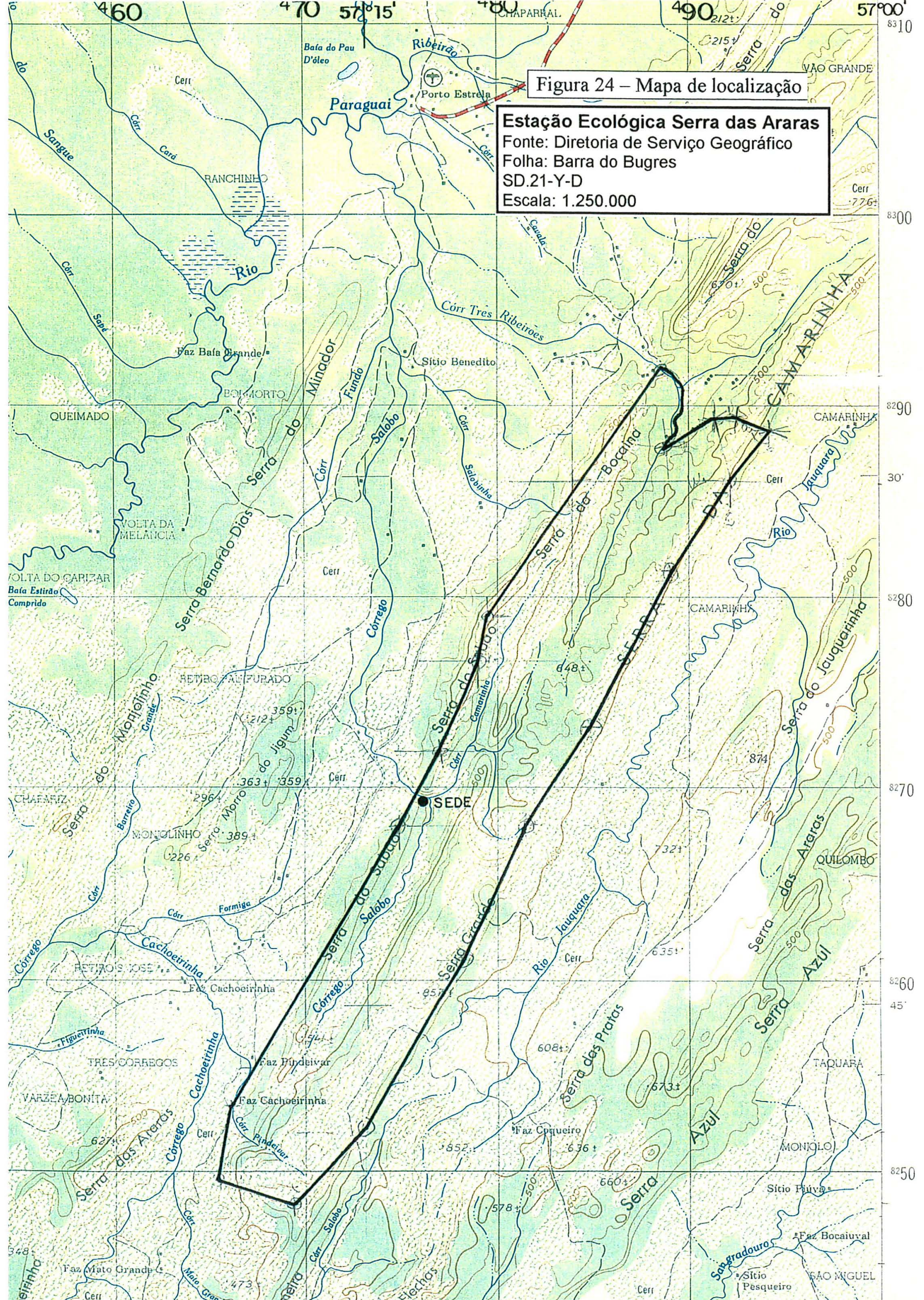




\section{II.1.2. Vias de Acesso}

O acesso à sede principal da Estação, dista aproximadamente 250 $\mathrm{km}$ de Cuiabá, podendo ser atingida via Barra do Bugres pela BR 163 ou via Cáceres através da BR 070. No sentido Cuiabá - Barra do Bugres através da BR 163 , são $130 \mathrm{~km}$ de asfalto e de Barra do Bugres em diante a estrada não é pavimentada, roda-se mais $80 \mathrm{~km}$, passando-se pela sede do Município de Porto Estrêla, distante $30 \mathrm{~km}$, e pelo Distrito de Saloba Grande, distante $5 \mathrm{~km}$ da sede principal.

O outro acesso, via Cáceres, dista $110 \mathrm{~km}$ até à sede, sendo muito difícil, posto que não existe estrada após a fazenda Samambaia, no limite sul.

\section{Il.1.3. Histórico da Unidade de Conservação \\ e Antecedentes Legais}

O processo de implantação da Estação Ecológica, teve início, quando Paulo Resende, representante da SEMA em Mato Grosso, recebeu indicação do INCRA, na pessoa do Engenheiro Ricardo Camargo, da existência de um "vale desocupado" e isolado, com 28.700 ha de área (Nogueira Neto, 1992).

$A$ área foi avistada quando voavam rumo ao norte, a uns quarenta ou cinqüenta quilômetros de Cuiabá, sobrevoando uma série de serras paralelas, que se estendiam no sentido Leste-Oeste, com bifurcação de uma delas, entre Barra do Bugres e Cáceres, constituindo-se assim num vale acidentado e praticamente fechado, com uma estreita garganta rochosa para a saída de suas águas. (Nogueira Neto, 1992).

Mas sem a firme atuação das pessoas citadas e de Paulo Pitaluga, que muito colaboraram, a Estação não teria sido implantada. $A$ ocupação não foi tarefa das mais fáceis, devido a área ser muito acidentada, tendo-se que utilizar dinamite para a abertura de uma precária estrada, na estreita garganta que corta a serra. Esta decisão provocou muita polêmica, mas em se tratando de uma Estação Ecológica, optou-se pela construção do acesso aos pesquisadores. Apesar da 
utilização de tais explosivos, o caminho aberto ainda é precário. Ultimamente, com alguns "reparos", está sendo possível chegar-se com a Toyota até à Estação .

Nos anos 80, a Estação correu sérios riscos, pois fora anunciado por uma emissora de Cáceres, que a reforma agrária se iniciaria pelas terras do governo e a Estação, a área mais próxima da cidade, pertencente ao governo Federal, bastou para que umas quarenta familias ocupassem a área. Foram tomadas duas providências para desocupar a Estação, com pedido de não violência contra os posseiros, por parte do então Secretário do Meio Ambiente Paulo Nogueira Neto. Uma delas foi a intervenção do INCRA, reassentando as famílias em outros locais e também a solicitação da presença da Polícia Federal, ficando evidente a determinação na posse dessa área por parte do Órgão (Nogueira Neto, 1991).

A Estação Ecológica Serra das Araras, foi criada pelo Decreto. Federal no 87.222 de 31 de maio de 1982, composta por 2 áreas contíguas, uma delas com 24.790 ha denominada Serra das Araras I, no Município de Barra do Bugres, e a gleba Serra das Araras II, no Município de Cáceres, com 3910 ha, confrontantes com Sesmarias ao norte e ao sul da área, com termo de entrega à SEMA, conforme processo $n^{\circ}$ 0768-043758/81-08 de 20/05/1982, totalizando uma área de 28.700 ha, hoje toda ela localizada no Município de Porto Estrela.

\section{Il.2. Características Biofísicas}

\section{Il.2.1. Clima}

Pode ser classificado como tropical quente a semi-úmido, com 4 a 5 meses de seca (Nimer citado por Sonoda, 1991).

As condições climáticas dessa região são condicionadas pela diversidade fisiográfica da bacia do Alto Paraguai, aliada à circulação atmosférica. Dentre as massas de ar que influenciam a Estação destacam-se: a Frente Polar (FP), as Massas de Convergência Intertropical (CIT) e as massas de Instabilidade Tropical (IT) (Brasil, 1982). 
As precipitações pluviométricas giram em torno de 1300 a $2000 \mathrm{~mm}$ anuais, apresentando regime tipicamente amazônico, ocorrendo um mínimo de precipitação no período de maio a setembro e um máximo de dezembro a fevereiro. As temperaturas médias são altas durante 0 ano, com pouco declínio durante os meses de julho e agosto.

As médias anuais oscilam entre $23^{\circ}$ e $25^{\circ} \mathrm{C}$ e a média das temperaturas máximas entre $30^{\circ}$ e $32^{\circ} \mathrm{C}$.

Nos meses chuvosos, entre novembro e abril, a umidade relativa do ar ultrapassa $80 \%$, caindo para menos de $60 \%$ no período da estiagem (Brasil, 1979).

\section{Il.2.2. Geomorfologia e Geologia}

A Estação encontra-se na Unidade geomorfológica denominada província serrana, correspondendo às bordas do Planalto Central, tratando-se pois de uma área de relevos dobrados individualizados e por uma sucessão de anticlinais e sinclinais alongados seguindo direção $\mathrm{NE}$, entre a borda sul da plataforma do Guaporé e a extremidade noroeste da bacia do Paraná (Brasil, 1982).

Esta área inclui a formação "Araras" (formada por calcário, elemento muito valorizado e explorado atualmente), "Raizama", "Diamatino", "Bauxi", "Moenda" e "Sepotuba", pertencentes ao Grupo Alto Paraguai (Brasil, 1979).

Tais serras apresentam direção NE-SO e possuem estruturas dobradas e muito dissecadas por processos erosivos, com cristas em forma aguçada, tabular ou convexa separadas por vales em "V"ou de fundo plano (Brasil, 1982). Vide figura 25.

\section{II.2.3 Solos}

A Estação situa-se na província serrana, onde os solos são litólicos, pouco desenvolvidos, com o horizonte $A$, diretamente assentado sobre a rocha matriz, pouco profundo (igual ou inferior a $50 \mathrm{~cm}$ ), possuindo características físicas 
e químicas bastante heterogêneas, que variam de acordo com o material de origem.

São solos fortemente susceptíveis aos processos erosivos, em virtude de sua reduzida profundidade efetiva e forma de relevo das áreas que ocorrem. Associados a eles podem ocorrer afloramentos rochosos, indicando embasamento exposto à superfície.

Os solos dominantes são de três tipos: Podzólico Vermelho amarelo eutrófico, latosșolo vermelho-amarelo distrófico e litólito eutrófico, com quotas oscilando de 200 a 900 metros nas partes mais elevadas da Província Serrana, com solo arenítico, onde ocorre a vegetação de campo cerrado. E nas partes mais baixas, nos vales estruturais, o solo é podzólico vermelho-amarelo, favorecendo condições de uma vegetação tipo cerradão, devido a um certo acúmulo de matéria orgânica (Brasil, 1982).

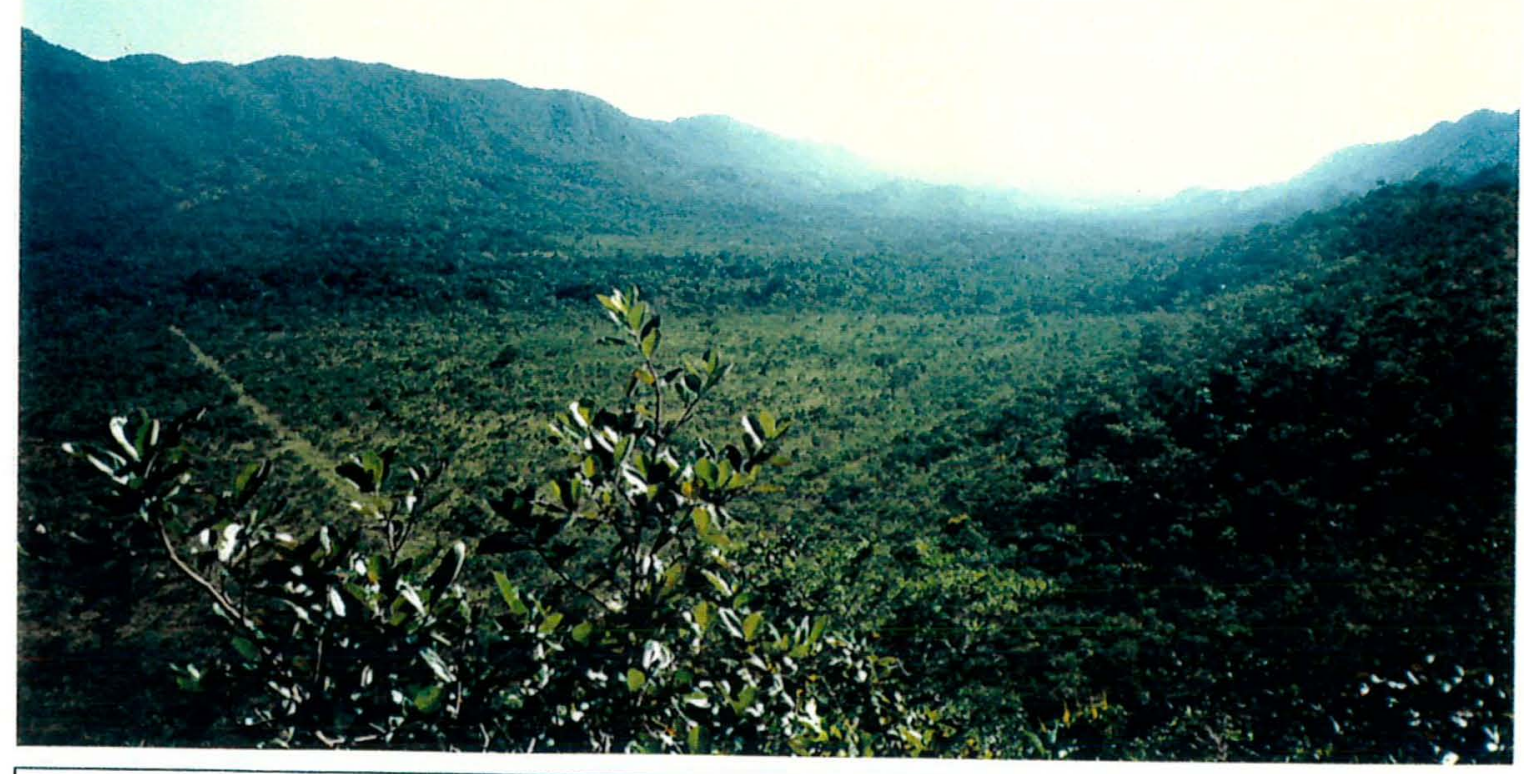

Figura 25 - Aspecto do vale da "Saloba", próximo á sede. 


\section{II.2.4.Hidrografia}

Três cursos de água, com seus afluentes cortam a área: o Rio Saloba a oeste, Córrego Pindeiva ao sul, e Três Ribeirões ao norte com inúmeros pequenos cursos d'água aflorando em meio a blocos rochosos de arenito correm por entre vales e fendas e acabam por desaguar nos córregos Ribeirão, Salobinha, Três Ribeirões e Pindaivá, nos rios Saloba Grande, Flexas, Jauquara e no afluente do Rio Cachoeirinha.

A Estação Ecológica da Serra das Araras, encontra-se à margem esquerda do rio Paraguai e funciona como divisor de microbacias (Rio Jauquara, Flexas, Saloba Grande e Cachoerinha), sendo que o Rio Saloba Grande deságua diretamente no Rio Paraguai, a algumas dezenas de quilômetros ao sul da Estação (Figura 26). Os outros rios deságuam no Jauquara, que por sua vez é afluente do Paraguai, fazendo parte da bacia do Alto Paraguai.

Nessa região são encontrados cursos d'água perenes e intermitentes, com águas que podem ser classificadas em doces e salobras (Sonoda, 1991).

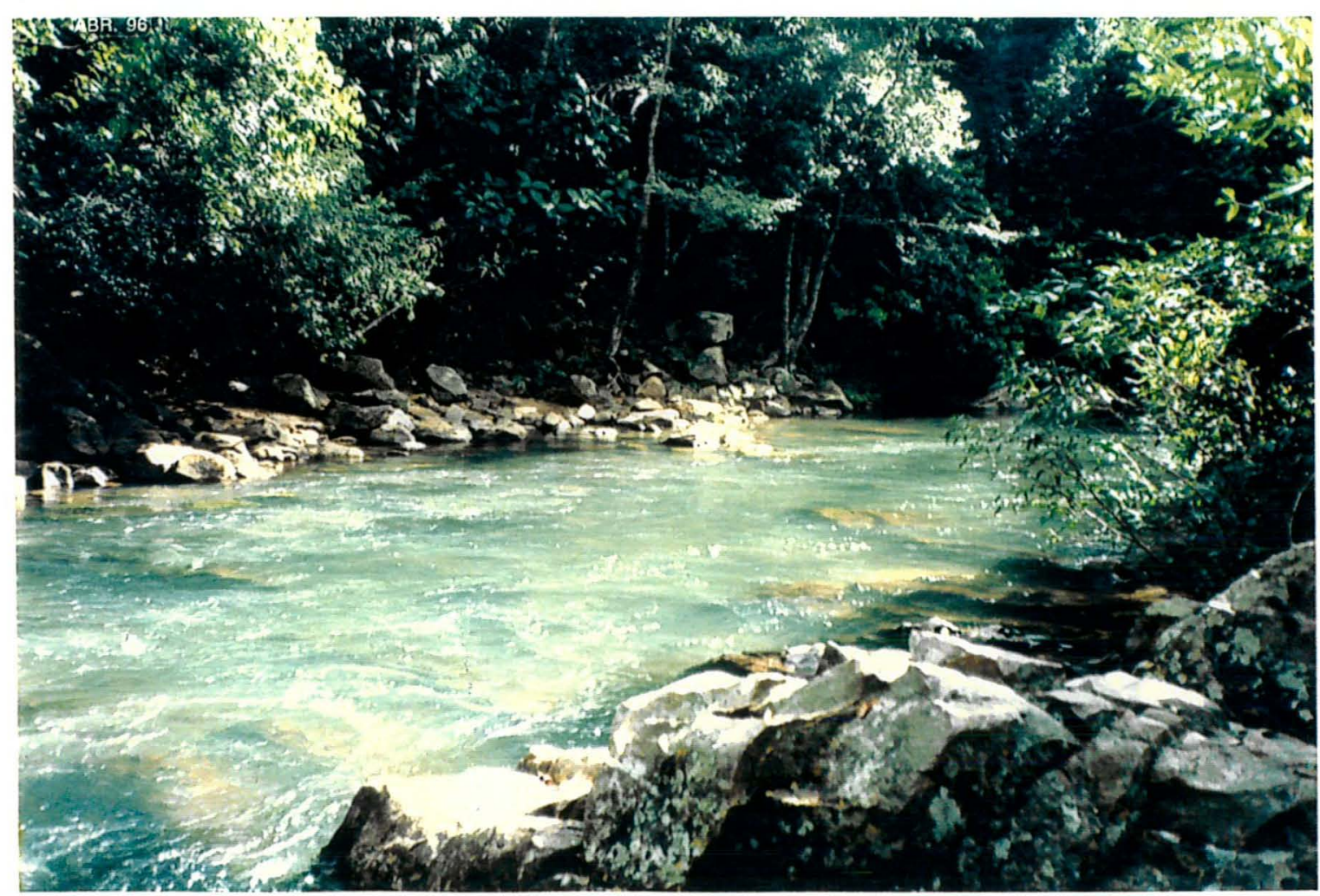

Figura 26 - Vista do Rio Saloba, ao lado do caminho para sede. 


\section{Il.2.5 Vegetação}

A vegetação dominante é a típica do Brasil Central, com diferentes tipos fisionômicos. Os principais são: campo limpo, cerrado "sensu stricto" e cerradão; e além desses há consideráveis extensões ocupadas pelas matas de galeria e seus consorciados (veredas e brejos), que se insinuam acompanhando os diversos cursos d'água existentes, tanto nos vales como nas nascentes (Brasil, 1982).

Savana parque (campo sujo) - Em grandes extensões no vale, encostas e topo das Serras Grande e Sabão, essa formação é dominante, composta por árvores esparsas. $\mathrm{Na}$ composição florística predominam as gramíneas mescladas com outras ervas, subarbustos e árvores esparsas.

Encontram-se ainda, nessa região outros gradientes de "cerrado" e alguns tipos vegetacionais que também estão relacionados com fatores como o clima, relevo, geologia, solo, altitude, e se destacam pela sua importância biológica, tais como:

Cerrado "sensu stricto"- Distribui-se entre as encostas, apresentando dois estratos bem distintos: no inferior predominam as gramineas $e$ ervas e no superior, árvores com $5 \mathrm{~m}$ de altura, em média. Entre os elementos que compõem a flora do cerrado da Estação, destacam-se: lixeira (Curatella americana), ipê-amarelo (Tabebuia caraiba), capotão (Salvertia convallariodora), nó-de-cachorro (Heteropterys aphrodisiaca), mangaba-brava (Lafoensia pacari), angélica (Himatanthus obovata) e outros (Guarim Neto et al., citado por Sonoda, 1991).

O cerrado adjacente à sede, no vale da Estação, caracteriza-se por denso tapete graminoso, povoado de modo uniforme mas esparso, por arbustos baixos e por arbustos raquíticas ("scrub"), de córtex bastante suberoso, espesso e sulcado, que alcançam altura média de 1,5 a $2,5 \mathrm{~m}$, com alguns poucos indivíduos atingindo os 4-5 metros de altura (Strussmann, 1988).

Não há afloramento rochoso nesse cerrado do vale da Estação, estabelecido sobre solo argiloso, mas diferentemente, ao longo da borda superior da serra, que separa as matas de encosta e os campos estacionalmente úmidos 
são característicos matacões, lajeiros e solo concrecionário recoberto de piçarra (Strussmann, 1988).

Mata ciliar - Acompanhando os cursos d'água perenes ou não, apresenta uma vegetação de folhagens normalmente verdes, caules eretos e com altura atingindo cerca de 8 a $8,5 \mathrm{~m}$. Significante é a quantidade de matéria orgânica acumulada favorecendo o crescimento e desenvolvimento de briófitas e pteridófitas. Trepadeiras dos gêneros Dioscorea, Heteropterys, Paulinia, entrelaçam no caule e ramos mais baixos dos vegetais. $O$ estrato herbáceosubarbustivo, está constituído por espécies de Graminae, Rubiaceae, Acanthaceae e outras. De uma maneira geral ocorrem ainda, negramina Siparuna guianensis, camboatá Cupania vernalis (Guarim Neto et al., citado por Sonoda, 1991).

Nas matas ciliares dos rios Saloba e Ribeirão, também ricas em folhedo, ocorrem frequentemente diversas espécies de palmeiras, entre as quais o acuri (Scheelea phalerata), babaçu (Orbgnya speciosa) e tucum (Astrocaryum sp.). Nas margens desses rios as praias de areia são pouco frequentes, sendo mais comuns praias ou banco de seixos e barrancos abruptos, argilosos ou talhados em paredões de calcáreo (Strussmann, 1988).

Babaçual - Distribuem-se em áreas próximas à mata ciliar, predominando a Palmeira (Orbignia martiniana). Nessas comunidades nota-se maior aglomeração e conseqüente adensamento dos indivíduos dessa espécie, havendo penetração de indivíduos de Physocalimma saberrima. Margeando o babaçual pode-se ainda encontrar espécies herbáceas-subarbustivas de Compositae, Helicteres, Cyperaceae, Bauhinia, etc (Guarim Neto et al., citado por Sonoda, 1991).

Campo Limpo Com Veredas - É encontrado no topo da Serra do Tombador e constituído por extensas áreas úmidas composta principalmente por Gramineae e pindaíbas (Xilopoia sp), sendo dessas áreas que aparecem inúmeras nascentes que vão alimentar os córregos e rios da região, componentes da bacia do Paraguai (Guarim Neto et al., citado por Sonoda, 1991). 
Campos Rupestres - Aparecem nas regiões de maior altitude com vegetação típica de Bromeliaceae, Graminae, Veloziaceae, Cactaceae, (Guarim Neto et al., citado por Sonoda, 1991).

Mata de Calcáreo - Vegetação composta por árvores com copas

variando de acordo com a localização, mas geralmente entre 6 a $15 \mathrm{~m}$. Assemelha-se muito à caatinga do Nordeste, tipo alto de mandacaru (Cereus $s p$ ) muito comum no local. A vegetação é tipicamente caducifolia (Guarim Neto et al., citado por Sonoda, 1991).

\section{Il.2.6. Fauna}

A diversidade de ambientes na Estação Ecológica Serra das Araras, favorece a existência de uma fauna bastante diversificada. Essa região de morrarias torna-se um excelente corredor geográfico de muitas espécies migratórias que vão para o pantanal dar início ao ciclo reprodutivo anual. É o caso da garça branca grande Casmerodius albus, cabeça seca Mycteria americana, o socózinho Butorides striatus, o colheireiro Ajaja ajaja, o biguá Phalacocorax olivaceus e outros ( Cintra s/d citado por Sonoda, 1991).

Apesar dessa região ser geograficamente um contorno ao norte da planície pantaneira, foram encontradas algumas espécies de aves que não ocorrem no Pantanal, pelo menos no de Poconé, como por exemplo o falcão (Daptrius americanus), o pica-pau Melanerpes cruentatus (pica-pau de barrigavermelha), a arara Ara manilatta (maracanã do buriti), a pega (Cissops leveriana), etc (Cintra op.cit.).

\section{Il.2.6.1. Habitats e as Aves}

A vegetação chamada de campo limpo, em pequenos trechos de vales, nas encostas e no topo das serras com solos pedregosos, apresenta poucas espécies de aves com grandes populações, sendo mais comuns os Columbídeos, Columbina talpacoti (rolinha-caldo-de-feijão) e Columbina minuta 
(rolinha de asa canela) e os Emberezídeos Sphorofila nigricolis (coleiro-baiano) e Volatina jacarina (tziu) que são atraídos pela grande quantidade de sementes disponíveis, mas também forrageiam outros habitats (Silva \& Oniki, 1988).

O campo sujo ocupa grandes extensões no vale, encostas e topo das Serras Grande e do Sabão, sendo encontradas mais freqüentemente nesse tipo de formação vegetal, aves como a siriema Cariama cristata e o rinocriptídeo Melanopareia torquata (meia lua do cerrado) (Silva \& Oniki, 1988).

O cerradão apresenta-se bastante modificado, ocupando uma área diminuta, sendo as aves registradas nesse ambiente o tinamídeo Crypturellus sowi (tururim), o caprimulgídeo Chordeiles acutipennis (bacurau-de-asa-fina) e os formicarídeos Thaminophilus punctatus (choca-bate-cabo) e Formicivora grisea (formigueiro-pardo) (Silva \& Oniki, 1988).

A diversidade da mastofauna é representada por inúmeras espécies que se encontram ameaçadas ou em vias de extinção, como o macaco coatá (Ateles paniscus), o veado campeiro (Ozotocerus bezoarticus), a onça-pintada (Panthera onca), o cachorro do mato vinagre (Speothos venaticus), tatu canastra (Priodontes giganteus), tamanduá-bandeira (Tamandua tetradactyla) (UFMT, 1989).

Entre os anfibios ocorrem representantes das familias Hylidae, Leptodactylidae e Dendrobactidae (UFMT, 1989).

Observa-se comumente a presença de cobras como a venenosa cascavel (Crotalus sp.) e jararacas (Botrops spp.), além de muitas outras. Podem ser encontrados lagartos, como teiús e ameivas (UFMT, 1989).

A fauna entomológica está representada por 10 ordens e 80 famílias (UFMT, 1989).

Nos rios e córregos da Estação Ecológica, encontram-se camarões Macrobratium spp., peixes, como a traíra (Hoplias sp.), lambaris (Astyanax sp.), cascudos (Hypotamus sp.), bagres (Pimelodus sp.), carás (Aequidens sp.) entre outros (UFMT, 1989).

Todos os cinco grupos de répteis encontram-se representados na Estação, segundo Strusmamm (1988). 
Entre as tartarugas são comuns os cágados do gênero Phrynops, que habitam os riachos de leito pedregoso e águas salobas originados nas Serras do Sabão, Grande, Pindeivar, Tombador, Camarinha, Bocaína e Três Ribeirões. Esses riachos também são ocupados pelo jacaré-coroa (Paleosuchus palpebrosus), espécie de hábitos pouco conhecidos (Strusmamm, 1988).

O jaboti (Geochelone sp), espécie que já foi mais abundante na área da Estação, parece ter sido afetada pela caça predatória e pela degradação dos ambientes de mata (Strusmamm, 1988).

Entre os lagartos encontrados com maior frequência está o "PaiJosé" (duas espécies de Tropidurus torquatus e T. itambere). Estes sã̀o vistos correndo sobre blocos rochosos e troncos caídos nas matas das encostas, nos campos rupestres e nos cerrados da Estação. Um outro "parente" próximo, dotado de uma pequena crista dorsal (Tropidurus spinulosus) freqüenta troncos das matas mais úmidas que margeiam os cursos d'agua (Strusmamm, 1988).

A curiosa "vibora" (Hoplocercus spinosus), pequeno lagarto de cauda curta e espinhosa, injustamente temido pela maioria dos habitantes da região, é encontrada na mata de encosta, em tocas escavadas sob pedras ou troncos (Strusmamm, 1988).

Encontram-se com frequência pequenos lagartos dos gêneros Kentrops a Anolis (papa-vento), nas formações abertas do tipo campo-sujo, onde predominam as gramíneas, entremeadas por arbustos e árvores baixas esparsas (Strusmamm, 1988).

Nos babaçuais e capoeiras formados pela ação antrópica no Vale do Rio Saloba, no alto das palmeiras e de outras árvores é encontrado com frequência o sinumbú (Iguana iguana), grande lagarto verde que se alimenta de folhas e brotos. Também são encontrados o calango-verde (Ameiva ameiva) e o teiú (Tupinambis teguixin), ambos lagartos do chão, adapatados a esse tipo de ambiente alterado (Strusmamm, 1988).

Cobras cegas (Amphisbaena alba) e serpentes de várias espécies são encontradas com frequência na área da Estação em certas épocas do ano (Strusmamm, 1988). 
Nas matas ciliares é comum a ocorrência de uma serpente venenosa do grupo das jararacas, localmente denominada "boipeva", "boca de sapo" ou ainda "rabo de osso" (Botrops moojeni). Caninanas, dormideiras e cobras-cipó são abundantes nas matas ciliares de encosta. A sucuri-amarela (Eunectes notaeus) é encontrada ao longo dos córregos e matas marginais (Strussmann, 1988).

É dentro do grupo dos anfibios que na área da Estação, encontra-se o maior número de espécies novas (Strussmann, 1988).

\section{II.3. Ocorrência de fenômenos naturais e suas conseqüências}

O fogo na Estação Ecológica pode ser de origem natural (descargas elétricas) como pode ter origem antrópica, principalmente oriundo da vizinhança, que utiliza-se do fogo, para o manejo das pastagens e roçados.

Nesta região, ventos sopram anualmente de agosto a outubro, que mudam rapidamente de direção, e no caso de incêndio, muitas vezes colocam em perigo até a própria sede da Estação.

$\mathrm{Na}$ Estação existem 16 bombas costais, com capacidade para 20 litros, abafadores com cabo de alumínio e que não são utilizados, devido ao peso e por ser difícil carregá-las por entre a vegetação. Quando da ocorrência dos sinistros, fica muito difícil subir a serra com cantil, lanterna, abafadores e as bombas costais. Segundo os próprios funcionários, torna-se preferivel utilizar a vegetação local, como abafadores. A inexistência de trilhas, dificulta 0 acesso aos locais de maiores riscos de incêndios.

A partir de 1990, a Estação participa do programa PREVFOGO, desde a ocorrência de um incêndio, que foi debelado por uma chuva providencial.

Muitas vezes, o fogo é combatido por um corpo de voluntários da vizinhança. 


\section{Il.4. Características sócio-econômicas e culturais}

\section{Il.4.1. Situação Fundiária}

Constata-se pela documentação estudada, conflito de informações sobre a regularização fundiária da Estação Ecológica Serra das Araras. Enquanto nos registros da DIREC/BSB, consta toda a área da Estação como regularizada, o chefe da Estação informa a existência na área de proprietários, com títulos de posse registrados em cartório.

No limite norte, a Fazenda Bocaína ocupa uma área da Estação que foi transformada em pastagens; bem como outra posse de aproximadamente 500 hectares na Serra Três Ribeirões. No limite sul da Estação a Fazenda Pindorama ocupa aproximadamente 500 ha da Estação próximo ao Córrego Pindeivar e a fazenda Samambaia (propriedade de Mário Furquim), com 1.262 hectares dentro da ESEC, na Serra da Palmeira, no alto do Chapadão (IBAMA, 1990).

\section{II.4.2. Uso da Estação}

Como foi visto anteriormente existem usos inadequados por parte dos proprietários com litígio na Estação, os quais utilizam o fogo para a formação e manejo das pastagens, que, muitas vezes, vem a causar grandes incêndios na Estação, que são aumentados com ventos que sopram na região, principalmente no período da seca.

A Estação é bastante utilizada, principalmente por alunos dos cursos de graduação em Biologia, Agronomia, Eng. Florestal, e Geologia da UFMT. Eventualmente a Estação é procurada por alguns pesquisadores para realizarem seus trabalhos em nivel de Mestrado ou Doutorado oriundos de Universidades do sudeste do Brasil. 


\section{Il.4.3. Histórico de Ocupação da Região}

$\mathrm{Na}$ região, em 1800, surgiram os primeiros moradores, que se dedicaram à criação de gado, cultura de arroz, feijão e milho, como também a exploração da poaia, vendida aos barqueiros do Rio Paraguai (EMPAER, 1996a).

$\mathrm{Na}$ década de 20 , pioneiros vindos de Cáceres, exploravam largamente madeiras como a araputanga (mogno), ipê, cedro, jatobá, peroba que eram beneficiadas na referida cidade (EMPAER, 1996a).

A caça teve destaque, devido a grande quantidade de animais ali encontrados na região como: a onça, o veado, o jacaré, a capivara, o caititu, etc.

Segundo relatos de antigos moradores e de alguns conhecedores da história local, os "Morroquianos", denominação dos antigos ocupantes da área da Estação, aí se instalaram há cerca de 80 anos. Descendentes dos negros e indios, são oriundos de povoados e fazendas próximas (Sonoda, 1991).

Os "Morroquianos" habitavam a "bocaina", região entre os vales encaixados e compunham uma comunidade de mais ou menos 17 familias, que encontraram condições para ali viverem durante muitos anos (Sonoda, 1991).

As atividades desenvolvidas eram a roça de subsistência e a criação de animais domésticos. As roças compreendiam pequenas porções de terras onde se cultivava arroz, feijão, milho, cana, mandioca, cará, café, algodão, abacaxi, banana e outros. Sendo o excedente comercializado em cidades próximas, percurso este realizado muitas vezes à pé, com a finalidade de se adquirir produtos como o sal e querosene (Sonoda, 1991).

A utilização da queimada, com a construção de aceiros, era prática comum entre os "morroquianos", que realizavam-na entre os meses de agosto e setembro, sempre nos dias mais quentes e sem vento, considerando também o dia de São Bartolomeu (24 de setembro) (Sonoda, 1991).

O rodizio de áreas cultivadas, era prática bastante comum, por isso não ficavam muito tempo num só lugar, mudando daqui para ali, na bocaína, sem cercas nem limites. As capoeiras, beiras de rios e beirada da serra, eram as áreas escolhidas para a preservação (Sonoda, 1991). 


\section{II.4.4. Aspectos Culturais}

Pouco se conhece de concreto sobre a arqueologia da região da Estação e seu entorno. Foi constatada a existência de pinturas rupestres, como no sítio da "Pedra do Rastro". Também, foram encontrados fósseis animais, em cavernas na fazenda Mata Grande.

Historicamente, na fazenda lindeira à Estação, de propriedade da ENCOMIND, conhece-se a casa onde se estabeleceu a Coluna Prestes, quando de sua passagem por Mato Grosso.

\section{II.5. Área da influência da Estação}

\section{II.5.1 - Faixa do Entorno}

No entorno da Estação, predominam pequenos proprietários, muitos deles moradores antigos da região, ocupam a sua base uma vez que os limites da Estação ficam no cume das serras.

Também nesse entorno, pode-se encontrar áreas ainda sendo "abertas" para pastagens e agricultura, principalmente nas médias e grandes propriedades, como se pode observar na figura 27.

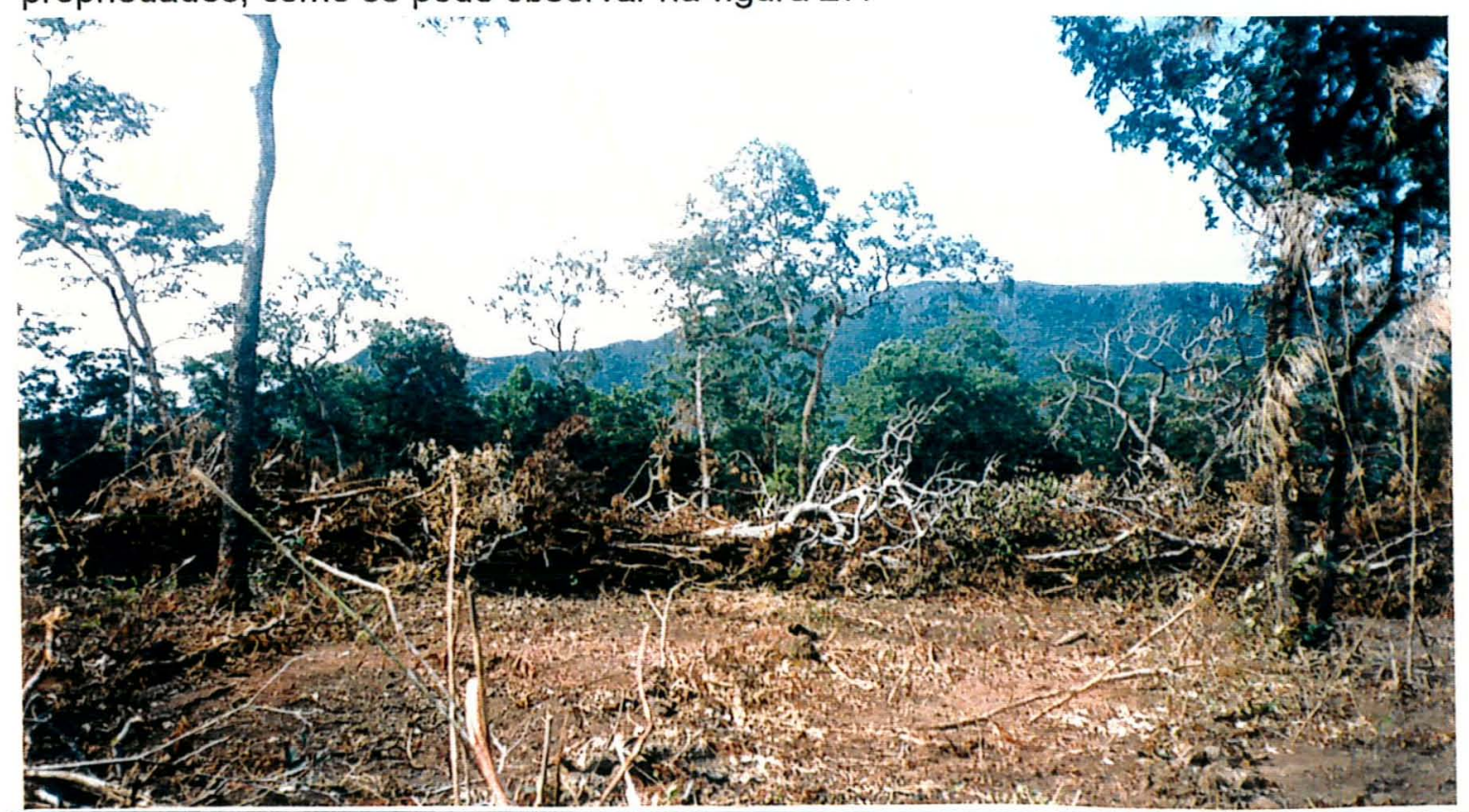

Figura 27 - Aspecto de uma área recém-desmatada para a agropecuária no entorno da Estação (ao fundo). 


\section{II.5.2. Cidade de Porto Estrela}

Cidade localizada no meio oeste de Mato Grosso, desmembrada da porção meridional de Barra do Bugres, passou a Municipio em 1991.

Com uma altitude média de 120 metros, faz divisa com a Serra das Araras. Apresentando formações montanhosas ao sul e sudeste do Município, perfazendo cerca de $35 \%$ de área montanhosa.

Segundo dados da EMPAER (1996g), o Município possui $45 \%$ de sua área desmatada, mas ainda são encontradas madeiras como a aroeira, ipêamarelo, louro preto, jequitibá e jatobá na região.

O Município é banhado por inúmeros cursos d'água de pequeno porte, todos afluentes do rio Paraguai. Os Rios Saloba Grande e Salobinha, sofrem intenso processo de assoreamento devido ao desmatamento. A pesca no rio Paraguai e afluentes é bastante representativa para o Municipio, onde predomina a população rural.

O sistema de cultivo predominante é o manual e o semimecanizado, composto em grande parte de pequenos produtores de algodão herbáceo, laranja, milho, e arroz de sequeiro. Predomina na área a pecuária de corte (EMPAER, 1996g).

\section{Il.5.3. Cidade de Barra do Bugres}

A partir de 1878 , teve início intensa procura pela poaia, como também em pequena escala, o plantio de cana de açúcar, para produção de açúcar e aguardente que supria a região. Outros, adentraram a região atrás de madeira, borracha, ouro e diamante (EMPAER, 1996a).

Com a desvalorização nos preços da ipeca e da borracha, surge novo ciclo, o da extração madereira, principalmente cedro e peroba.

Atualmente o Município, instalado em 1944, possui sua população concentrada na zona urbana e 50\% de sua área "aberta" (EMPAER, 1996a).

Predominam no município, as lavouras de cana-de-açúcar e a bovinocultura de corte (EMPAER, 1996a). 


\section{II.6. Aspectos Institucionais}

\section{II.6.1.Infra-Estrutura}

Atualmente a Estação, possui as seguintes construções:

1) sede da Unidade, que serve como escritório, moradia do Chefe e também como alojamento. Neste alojamento existe espaço para um pequeno laboratório. Construção em madeira, que acomoda 20 a 30 pessoas. (Figura 28).

2) Duas residências de madeira para os funcionários, junto à sede da Estação (Figura 29).

3) Uma casa de madeira no posto Três Ribeirões, localizada no extremo norte da Estação (Figura 30).

4) Casa do posto Jauquara, próxima da estrada que dá acesso ao lado sul da Estação, onde é mais fácil chegar pela BR 364.

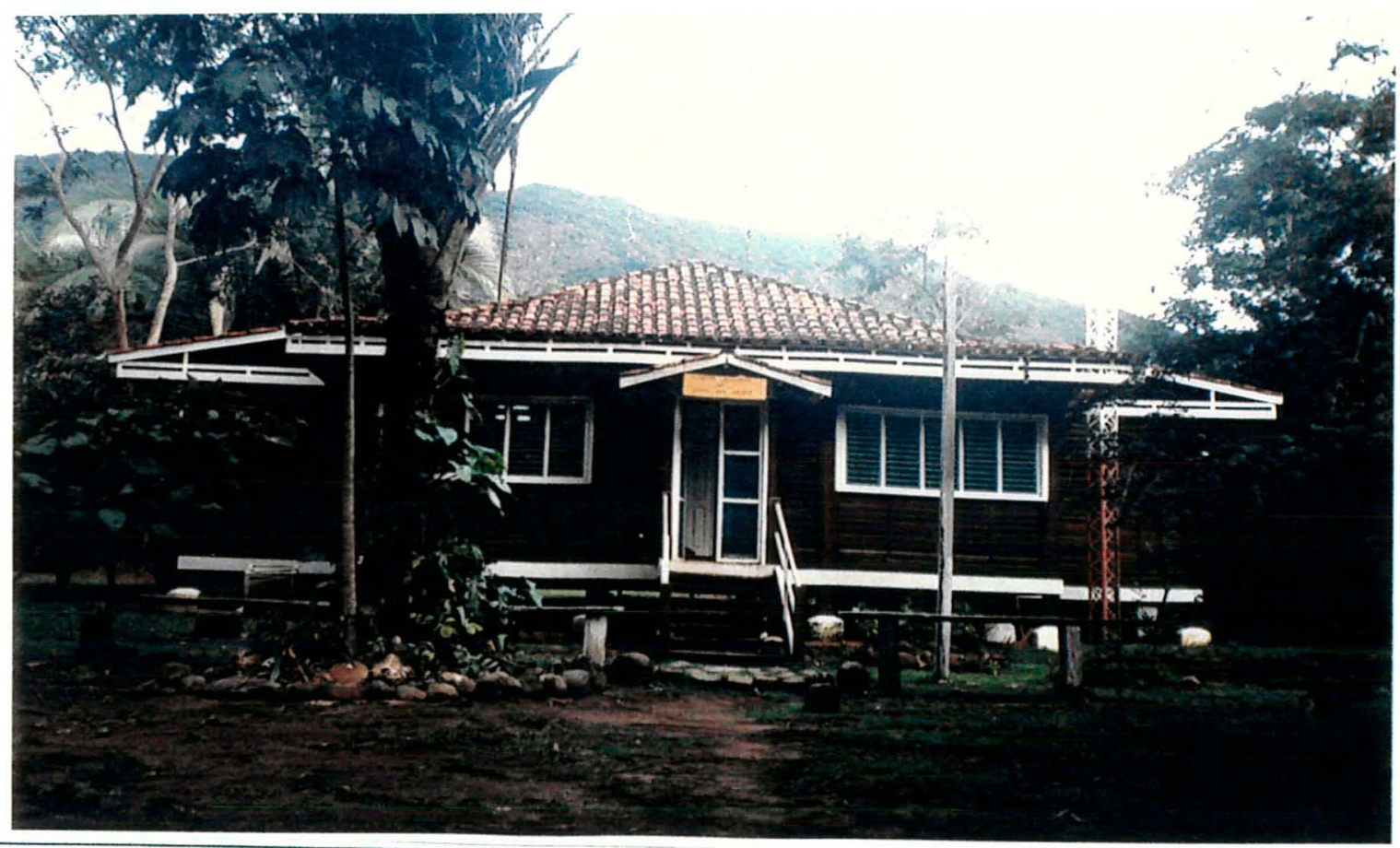

Figura 28 - Vista da sede da Estação Ecológica Serra das Araras. 


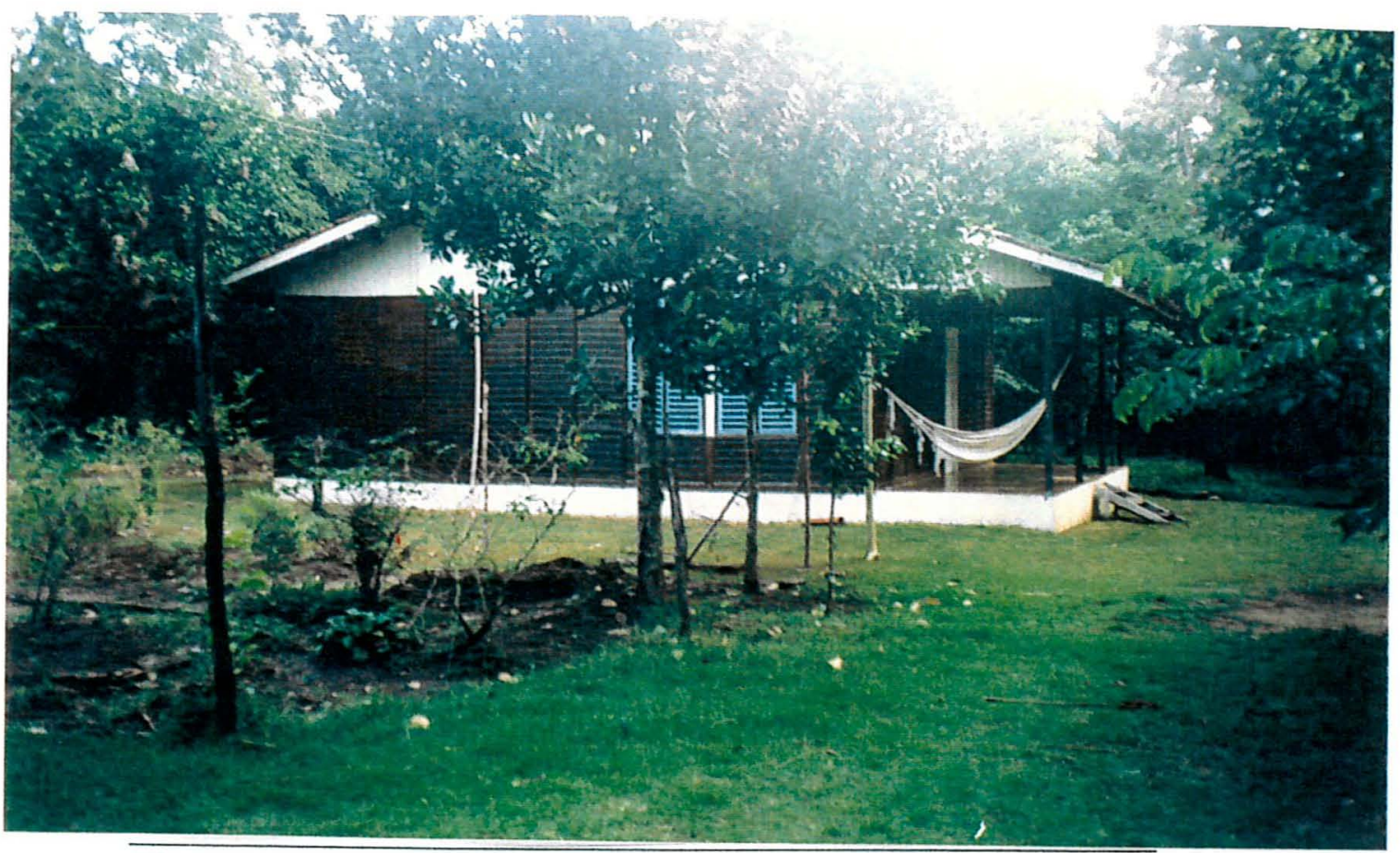

Figura 29 - Aspecto de uma das casas de funcionário junto á sede

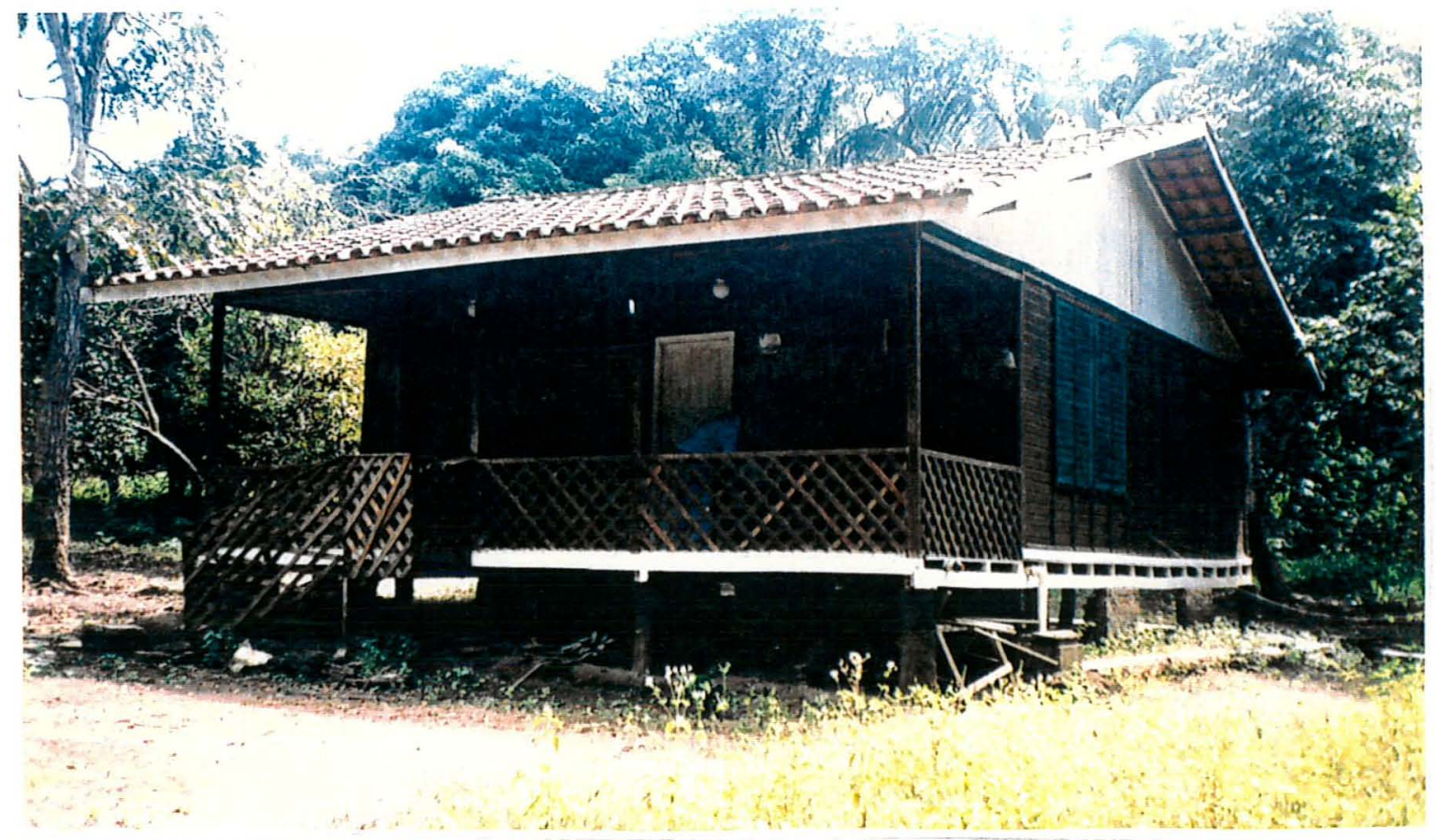

Figura 30 - Vista do posto "Três Ribeirões", no extremo norte da Estação. 


\section{II.6.2. Pessoal}

Tabela 03 - Quadro de pessoal da ESEC Serra das Araras

\begin{tabular}{|c|c|c|c|c|}
\hline Função/Cargo & Portaria /Nomeação & $\begin{array}{c}\text { Anol } \\
\text { Nascimento }\end{array}$ & Escolaridade & Cursos/área \\
\hline 1.Chefe ESEC & 0137/96 $\mathrm{P}$ de 30/01/96 & 1951 & $\begin{array}{l}2^{\circ} \mathrm{Grau} \\
\text { incompleto }\end{array}$ & $\begin{array}{l}\text { III Curso Planejamento } \\
\text { e Legislação em UC } \\
\text { 26/06 a 04/7/97 }\end{array}$ \\
\hline $\begin{array}{l}\text { 2.Aux.Operacional } \\
\text { Serviços Diversos" } \\
\text { Chefe Substituto }\end{array}$ & $\begin{array}{l}489 / 90 \mathrm{P} \text { de } 23 / 03 / 90 \\
1762 / 93 \mathrm{P} \text { de } 26 / 11 / 93\end{array}$ & 1936 & $\begin{array}{l}\text { I Grau } \\
\text { incompleto }\end{array}$ & \\
\hline $\begin{array}{c}\text { 3.Aux. Op. Serviços } \\
\text { Diversos }\end{array}$ & $542 / 90$ de $16 / 04 / 93$ & 1937 & $\begin{array}{c}\text { I Grau } \\
\text { incompleto }\end{array}$ & \\
\hline $\begin{array}{c}\text { 4.Aux. Op. Serviços } \\
\text { Diversos }\end{array}$ & $489 / 90$ de $23 / 03 / 90$ & 1942 & $\begin{array}{c}\text { I Grau } \\
\text { incompleto }\end{array}$ & \\
\hline $\begin{array}{l}\text { 5. Agente Defesa } \\
\text { Floresta|"*** }\end{array}$ & Decreto 177 de $12 / 09 / 91$ & 1946 & $\begin{array}{c}\text { I Grau } \\
\text { incompleto }\end{array}$ & $\begin{array}{c}\text { Brigada de Combate } \\
\text { Incendios Florestais } \\
16 \text { a 21/07/95 }\end{array}$ \\
\hline $\begin{array}{c}\text { 6.Aux.Op. Serv. } \\
\text { Diversos }\end{array}$ & $489 / 90$ de $23 / 03 / 90$ & 1946 & $\begin{array}{l}\text { I Grau } \\
\text { incompleto }\end{array}$ & $\begin{array}{l}\text { Capacitação Pessoal } \\
\text { p/Fiscalização nas UC } \\
\text { na Amazonia Legal1 }\end{array}$ \\
\hline
\end{tabular}

* Contratado pela ABES em 01/03/85 e contratado pelo IBAMA por tempo determinado em 23/03/90 por tempo determinado, através de Portaria 489/90.

** Contratada pela ABES por tempo determinado em 03/08/87 e contratada pelo IBAMA por tempo determinado em 01/02/90 e conforme Portaria 54293 de $16 / 04 / 93$ foi posicionada no quadro do IBAMA.

*** Contratado pela ABES por tempo determinado em 03/08/87 e contratado pelo IBAMA pela Portaria 489/90 de 23/02/90, por tempo determinado, sendo posicionado no quadro do IBAMA pela Portaria $542 / 93$ de 16/04/93.

***ะ Servidor do FNS, aproveitado para o cargo pelo IBAMA em 01/02/92.

***** Contratado pela ABES e posteriormente pelo IBAMA por tempo determinado, passando para o quadro do IBAMA pela Portaria $542 / 93$ de $16 / 04 / 93$.

\section{Il.7.Consideraçōes}

A Estação Ecológica tem como um de seus principais problemas, questôes fundiárias, em alguns de seus limites, que causam danos principalmente quando do uso do fogo nas pastagens, outro problema bastante grave da Unidade. Porém a ocorrência dos incêndios têm diminuido bastante, o que provavelmente possa ser atribuído ao trabalho de política de "boa vizinhança"do 
Chefe da Unidade e dos funcionários, através de uma educação ambiental informal com a população do entorno, antigos moradores conhecidos por "morroquianos".

Outro fato que chama a atenção são os limites da Estação demarcados no cume e não no sopé da Serra, fato que dificulta o controle para a fiscalização.

O acesso até há pouco tempo à sede era bastante difícil, sendo realizado á pé por caminhos íngremes, bem como o acesso pela estrada que leva à cidade de porto Estrela. Mas depois de algumas modificações na estrada podese chegar de Toyota á sede da Estação.

De todas as Unidades de Conservação é a que possui o maior número de funcionários em relação à sua área, porém não possui trilhas de monitoramento, com acesso é bastante dificil por ser regiâo serrana e ingreme, levando-se até um dia de caminhada dos postos de fiscalização até à sede.

Por estar próxima à região de conflitos por posse de terras e por ser uma das poucas áreas da União na região, os cuidados são redobrados para que não ocorram invasões na Unidade.

A região possui inúmeras cavernas, animais fósseis e pinturas rupestres, faltando maior incentivo para os estudos e lavantamentos desse material. 


\section{III.PARQUE NACIONAL DA CHAPADA DOS GUIMARÃES}

\section{III.1. Situação Histórica e Geográfica}

\section{III.1.1. Localização e Limites}

O Parque Nacional da Chapada dos Guimarães, está localizado na região central do Estado de Mato Grosso, nos Municípios de Chapada dos Guimarães e Cuiabá, entre as coordenadas $15^{\circ} 10^{\prime}$ e $15^{\circ} 30^{\prime}$ de latitude sul e $56^{\circ} 00^{\prime}$ e $56^{\circ} 40^{\prime}$ de longitude oeste. Criado pelo Decreto Lei no 97656 de 12 de abril de 1989, com uma área de 32.630 hectares e perímetro de $110 \mathrm{~km}$ (IBAMA, 1989). (Figura 32).

\section{III.1.2. Vias de Acesso}

A principal via de acesso para o Parque Nacional é a Rodovia Emanuel Pinheiro (MT 251), distante aproximadamente $30 \mathrm{~km}$ de Cuiabá e 09 km da cidade de Chapada dos Guimarães, a partir dos seus limites.

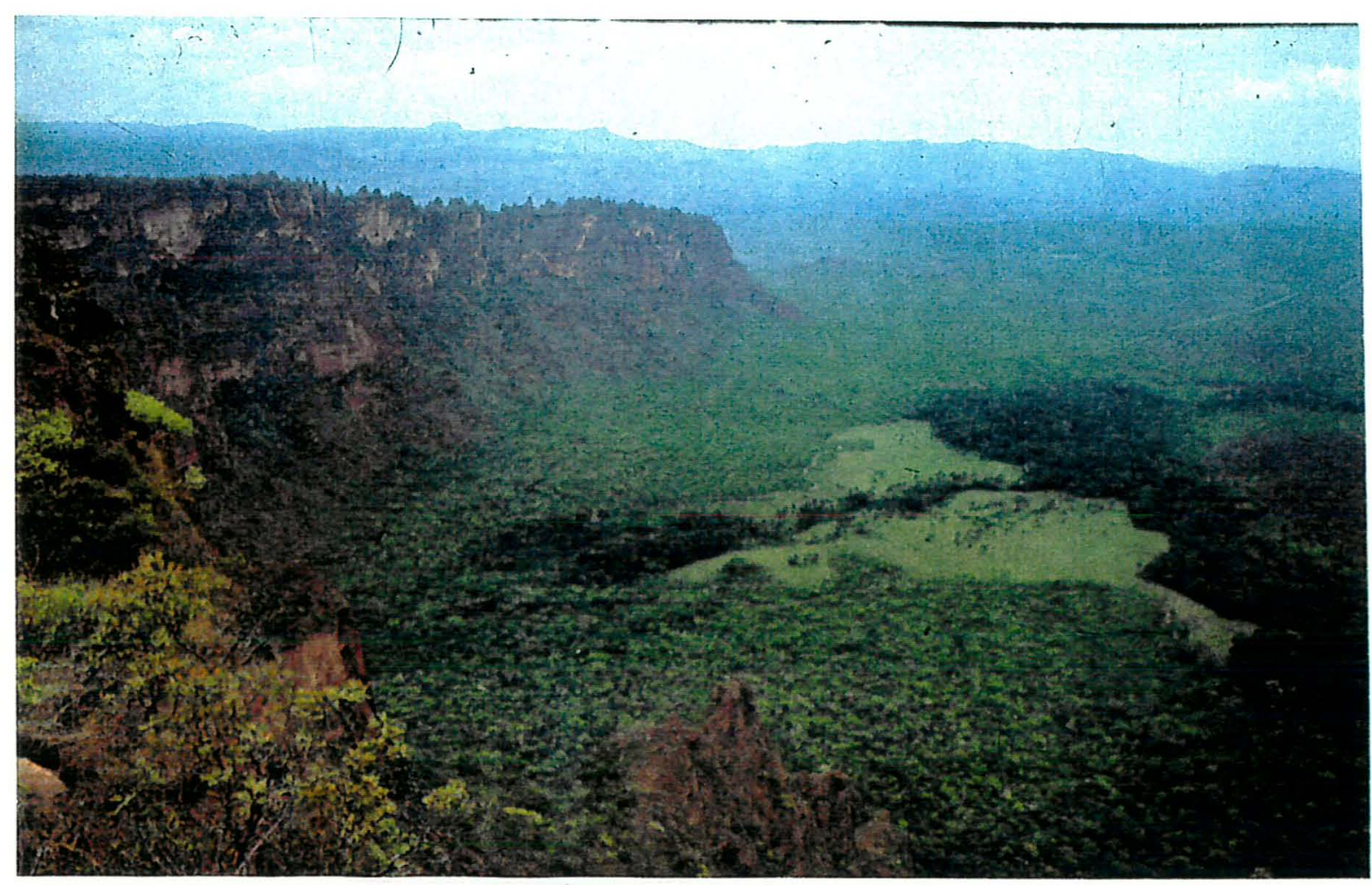

Figura 31 - Uma das vistas do PARNA de Chapada dos Guimarães. 


\section{III.1.3. Histórico e Antecedentes Legais}

A preocupação com a preservação dos remanescentes da flora na região onde hoje se localiza o Parque Nacional remonta do início deste século, com a intensa retirada da cobertura vegetal das Cabeceiras dos Rios Coxipó-Açú, Manso e Cuiabá, o que comprometeu a navegabilidade no Rio Cuiabá, no período da seca. 0 Vice Presidente do Estado de Mato Grosso, Cel. Pedro Celestino Corréa da Costa, através do Decreto $n^{\circ} 262$ de 13/09/1910 declara como de utilidade pública as terras devolutas da Encosta da Serra da Chapada, da sua base , 02 km a partir do Planalto; na zona do principal tributário do Coxipó-Açu, ao norte até o córrego das Caveiras, na Serra de Santa Tereza, as terras existentes nas cabeceiras dos Rios Cuiabá, Manso, Roncador, Casca e Jangada e seus afluentes até $6 \mathrm{~km}$ de suas nascentes, não podem ser alienadas a nenhum título (Brasil, 1995).

Brown, em 1970, propõe a criação de uma Reserva Biológica em Chapada dos Guimarães, fundamentado na enorme diversidade de flora e fauna (especialmente a entomofauna), nas belezas cênicas e nos valores culturais da região.

Através da Resolução o Conselho Nacional do Turismo (CNTur) n 819 de 02/04/76, declara como zona prioritária de interesse turístico, um polígono irregular de 30.000 ha, nessa região. O então Governador, Garcia Neto, considerando essa Resolução, declara a área como de utilidade Pública para fins de desapropriação, através do Decreto $\mathrm{n}^{\circ} 882$ de 09/02/1977 (Brasil, 1995).

Em 1974, através do Plano Diretor do Município de Chapada dos Guimarães, é proposta a criação de uma Zona de Proteção Permanente dos Recursos, na forma de um Parque Nacional. Somando a estas iniciativas Costa \& Jobim, também defenderam a criação do Parque Nacional, motivados pelos aspectos considerados por Brown, acrescendo a importância da hidrografia da região, que abriga cabeceiras de vários Rios de grande importância para a planície cuiabana, como o Rio Coxipó, Aricazinho, Formoso, Urubamba, Rio Claro, Salgadeira, Mutuca, Rio dos Peixes e Coxipó Açú (Brasil, 1995).

Em 1980, O Governador Frederico Campos, desapropriou áreas já utilizadas como pontos turísticos, como a região do Mutuca através do Decreto n 662 
de 29/10/80; a Salgadeira através do Decreto n 664 de 29/10/80; a Cachoerinha através do Decreto $n^{\circ} 663$ de 29/10/80 e Rio Claro através do Decreto oㅜ 648 de 17/10/80. Essas foram o início das ações governamentais, para que se concretizasse a vocação turística na região (Brasil, 1995).

Em 1984, foi criado o "Terminal Turístico da Salgadeira" e neste mesmo ano, lançado um manifesto através de grupos de ambientalistas, artistas e intelectuais, contra as arbitrariedades do Governo em relação ao meio ambiente, propondo-se a criação do Parque Nacional de Chapada dos Guimarães, através do Projeto de Lei no 405-A, de autoria do deputado Milton Figueiredo (Brasil, 1995).

A proposta teve como objetivo a conservação de locais como o Morro de São Jerônimo e Cambari; cidade de Pedras; Cachoeiras como Véu de Noivas, Andorinha, entre outras; Vale da Salgadeira, Jamacá e Benção; Mirante e Atimã, Rio Claro, Rio Mutuca e Rio dos Peixes; enfim preservando de forma especial as cabeceiras dos rios que deságuam nas bacias do Paraguai e Amazônica (Brasil, 1995).

No mês de fevereiro de 1986, foi desenvolvida uma campanha de âmbito nacional pela criação do Parque Nacional de Chapada dos Guimarães, sendo convidadas todas as entidades ambientalistas não governamentais brasileiras, para juntas enviarem correspondência, solicitando a criação do Parque Nacional ao então presidente da República José Sarney (Brasil, 1995).

Em junho desse mesmo ano, 1986, foi solicitado à Coordenadoria do Meio Ambiente, da então STDS (Secretaria do Trabalho e Desenvolvimento Social), que encaminhasse a mesma proposta para o CONAMA (Conselho Nacional de Meio Ambiente).

Somente em 1989, foi criado o Parque Nacional de Chapada dos Guimarães, através do Decreto Lei $n^{\circ} 97656$ de 12/04/1989, com o objetivo de proteger e preservar os ecossistemas existentes, assim como seus recursos naturais, sítios arqueológicos, e proporcionar ao público, educação ambiental e pesquisas (Brasil, 1995) 


\section{III.2. Características Biofísicas da Unidade de Conservação}

\section{III.2.1. Clima}

O fator da altitude, que varia de 200 a 800 metros, explica o caráter de transição, que as condições climáticas apresentam na região.

A área da Depressão Cuiabana, está incluída na categoria Aw (Köpen) e Cw representando o clima tropical de altitude do Planalto. Ambos são caracterizados pela presença de duas estações bem definidas: a de chuva (primavera e verão) e a de seca (outono e inverno). Na estação seca, pode ocorrer o fenômeno da "friagem", que é a invasão da massa polar sobre o continente, o que pode acarretar a queda de temperatura até $5^{\circ} \mathrm{C}$, que normalmente varia de $12^{\circ} \mathrm{C}$ a $25^{\circ} \mathrm{C}$ (Brasil, 1995).

O periodo das chuvas tem início em novembro estendendo-se até o mês de abril, e nos meses de janeiro a março, ocorrem as precipitações mais intensas. A taxa pluvial anual varia de 1800 a $2000 \mathrm{~mm}$, e a umidade relativa nos meses de novembro a abril é inferior a $80 \%$, e nos meses secos inferior a $60 \%$ (Brasil, 1995).

Nas encostas e vales ocorrem as ilhas climáticas, possibilitando a sobrevivência de grande número de espécies vegetais (Brasil, 1995).

\section{III.2.2.Geologia}

A área localiza-se sobre rochas paleomesozóicas da Bacia do Paraná, formando a Chapada dos Guimarães e sua base, aflorando na Depressão Cuiabana formada por rochas pré-cambrianas (Brasil, 1995).

A bacia sedimentar está representada pelos arenitos paleozóicos da Formações Furnas e Ponta Grossa, superpostas por terrenos mesozóicos constituídos por arenitos eólicos Botucatu, e parcialmente recobertos por sedimentos Bauru. Os depósitos cenozóicos estão representados principalmente pelos cascalhos dos rios atuais, e cangas, antigas e modernas (Brasil, 1995). 
4.III.2.2.1.Grupo Cuiabá (Pré-Cambriano) caracteriza-se por um pacote de metassedimentos dentríticos, fortemente dobrados. As rochas podem se apresentar cortadas por veios de quartzo leitoso, ligadas a atividade magmática. Os metassedimentos do grupo Cuiabá atingem espessura superior a $4000 \mathrm{~m}$, ocupando no Parque a faixa correspondente à peneplanície cuiabana (Brasil, 1995).

4.III.2.2.2.Grupo Paraná (Silurodevoniano) compreende a seqüência arenosa basal e uma argilo-arenosa superior relacionadas, respectivamente, as Formações Furnas e Ponta Grossa (Brasil, 1995).

1. Formação Furnas se constitui por um pacote arenoso de cores avermelhadas e esbranquiçadas, grãos subarredondados. Na parte basal ocorrem aglomeraçōes de matriz arenítica grosseira com seixos de quartzo de até $10 \mathrm{~cm}$ de diâmetro, variando de arredondados e angulosos. $O$ intenso fraturamento a que estão sujeitas as litologias da Formação Furnas formam, na área, "Canyons" de profundidades apreciáveis e escarpas íngremes (Brasil, 1995).

2.Formação Ponta Grossa compõe-se de folhetos siltitos cinza esverdeados e avermelhados, micáceos, fossiliferos, finamente laminados e arenitos finos a muito finos, argilosos, micáceos, grãos subarredondados, ocorrendo em bancos médios espessos. O registro fossilífero da Formação Ponta Grossa encerra uma rica fauna de invertebrados marinhos, constituída por alta frequência de braquiópodes (Australocoelia tourteloti), forma mais comum e com menor freqüência Tentaculites, Gastrópodes, Lamelibrânquios e Trilobitas (Brasil, 1995).

4.III.2.2.3. A Formação Botucatu se constitui essencialmente de sedimentos de granulação fina a média, pobre em arenito, com grãos bem rolados e foscos pelo trabalho eólico e grande escassez de drenagem.

4.III.2.2.4. A Formação Bauru compõe-se de matriz argilosa, vermelha com seixos arredondados e subarredondados de várias litologias e arenitos róseos, finos a médios, seleção retangular, calciferos, gräos arredondados, estratificados. 
Seus sedimentos friáveis condicionam um espesso solo arenoso, que forma extensos chapadões sem afloramentos rochosos. Com marcada escassez de drenagem, suporta uma vegetação homogênea de cerrado ralo. Entretanto, quando resistentes, livres de erosão, suas rochas podem condicionar um relevo diverso, com vales florestados e maior freqüência de cursos d'água (Brasil, 1995).

Cobertura Detrito-Laterítica é uma unidade edafoestratigráfica composta por três horizontes distintos basicamente constituídos por: detritos argiloarenosos de cores vermelha, marron e amarela. Formam extensas chapadas ou planaltos arenosos, com suaves ondulaçōes, drenagem de baixa freqüência, vegetação de "scrub" (Savana Parque) ou Savana Gramineo Lenhosa. As condições de temperatura, precipitação e a topografia plana do alto do chapadão, são ideais à formação de coberturas detrito-lateríticas. Supõem-se a idade Terciário/Quaternário para estes depósitos edafoestratigráficos (Brasil, 1995).

Ao longo dos rios estão os depósitos aluviais Quaternários e os recentes arenosos, exibindo a feição de terrenos alagadiços com o desenvolvimento de matas de galerias. Sobre o Planalto, o predomínio das formaçōes arenosas, propicia a expansão da erosão concentrada em vária ravinas e voçorocas, quando aceleradas pela ação antrópica (Brasil, 1995).

\section{III.2.3. Geomorfologia}

A área abrange duas unidades geomorfológicas: o Planalto dos Guimarães e a Depressão do Rio Paraguai.

1. O Planalto dos Guimarães estende-se pela extremidade noroeste da bacia sedimentar do Paraná e corresponde a trechos dos Planaltos divisores entre as Bacias do Prata e Amazônica. A oeste, noroeste e norte é contornada pela superfície rebaixada da Depressão Cuiabana e, na área do Parque Nacional representa duas subunidades geomorfológicas: a Chapada dos Guimarães e o Planalto do Rio da Casca.

1.1. A Chapada dos Guimarães corresponde a uma extensa área com relevo aplanado com encostas que variam de 600 a $800 \mathrm{~m}$ de altitude. Na parte 
sudoeste da Chapada encontram-se escarpas com vertentes muito abruptas, mantidas por arenitos Devonianos (Formações Furnas e Ponta Grossa). Essas rochas permitiram o modelado de um relevo com aspecto cuestiforme, cuja frente está voltada para a Depressão Cuiabana. Outro fato é a forte dissecação com ravinamentos de grande dimensão, fornecendo um aspecto de encosta frestonada. Mais ao sul, a escarpa torna-se mais abrupta e está moldada nos sedimentos Devonianos da Formação Furnas. Neste trecho; encontra-se ainda um relevo dissecado predominantemente em formas convexas e secundariamente em formas aguçadas e elaboradas em rochas do granito São Vicente (Brasil, 1995)

A superfície do topo da Chapada foi moldada em arenitos friáveis da Formação Bauru. Sobreposta, encontra-se a formação Cachoerinha que está associada à presença de ressaltos topográficos resultado do processo erosivo (Brasil, 1995).

1.2. Planalto do Rio da Casca representa o relevo que ocupa a parte noroeste do Planalto dos Guimarães.' Corresponde a uma área que sofreu um acentuado rebaixamento erosivo, comportando cotas altimétricas que vão dos 350 até $600 \mathrm{~m}$, apresentando a Sudeste escarpas das Chapadas dos Guimarães, enquanto que a Noroeste e Sudoeste é contornada pela Depressão Cuiabana. No contato com a Chapada dos Guimarães, observa-se também a presença de anfiteatros, produzidos a partir de processos erosivos, profundamente entalhados e delimitados por escarpas (Brasil, 1995)

As feições geomórficas predominantes neste planalto são as tabulares e convexas, ocorrendo também relevos residuais do topo tabular, cujos topos conservados acompanham o nível topográfico da Chapada dos Guimarães. Na faixa marginal das escarpas que marcam o contato do planalto à mencionada Chapada, observam-se relevos bastante dissecados, de topo aguçado e de topos convexos. $O$ Planalto do Rio da Casca foi elaborado basicamente em rochas de arenito das formações Bauru e Botucatu. Sobre estas llitologias desenvolveram-se predominantemente solos de Areia Quatroza e secundariamente Latossolos Vermelho-amarelo (Brasil, 1995). 
2. Depressão do Rio Paraguai é uma unidade que corresponde a extensas áreas rebaixadas e drenadas pelos tributários do alto curso do Rio Paraguai. A unidade apresenta diferenças regionais nas feições geomorfológicas e comporta altimetria distinta, ressaltando dos compartimentos de relevo bem individualizados, descritos como subunidades: Depressão Cuiabana (representada na área do Parque ) e Depressão do Alto Paraguai.

2.1. Depressão Cuiabana é subunidade que compreende uma área baixa entre o Planalto dos Guimarães e a província Serrana. Sua topografia, de modo geral, apresenta uma forma rampeada com inclinação de norte para o sul. A altimetria está em tomo de $200 \mathrm{~m}$ no limite sul e $450 \mathrm{~m}$ no Vale dos Rios Cuiabá e Manso. Apresenta uma dissecação composta predominantemente por formas tabulares, secundariamente por formas aguçadas (a oeste) e convexas (no vale do Rio Manso). Os grandes e pequenos cursos d'água são influenciados pelos direcionamentos estruturais preferenciais (NE-SO), que as rochas do grupo Cuiabá apresentam (Brasil, 1995).

\section{III.2.4. Hidrografia}

Os rios que se destacam no Parque são: Córregos Água Fria e Estiva, ambos afluentes do Rio Quilombo, ao norte; o Rio Coxipó, onde se destacam as cachoeiras "Véu de Noivas" e "Pedra Furada", ao sul, no seu afluente Independência, localizam-se as mais notáveis cachoeiras, como "Sorrizal", "Pulo", "Degrau", Malucos e "Andorinhas". Na margem direita do Coxipó, destacam-se o córrego da Salgadeira e os Rios Claro e Mutuca. A leste, destacam-se os Rios Cachoerinha e Acorá, afluentes do Rio Quilombo, e a oeste os Rios Coxipó-Açú, Machado e Bandeira e Ribeirão Dois Córregos. O Rio Aricazinho e alguns dos seus afluentes nascem dentro da Unidade, no trecho compreendido entre a Serra do Quebra Gamela e a estrada Tope de Fita. Todos estes rios são formadores do Rio Cuiabá, um dos principais rios formadores do Pantanal Mato-grossense (Brasil, 1995). 


\section{III.2.5. Vegetação}

Provavelmente, a diversidade de clima foi o fator que mais influenciou na ocorrência de diferentes tipologias vegetacionais na região, destacando-se:

4.III.2.5.1. Mata Semidecídua: Interpretada como matas de Encosta e Ciliar.

1. Na Mata de Encosta (ou Interflúvio) o caráter morfodinâmico tem grande expressão por caracterizar ambientes microclimáticos, ocorrendo associada as áreas das cabeceiras dos rios perenes, tributários do Rio Cuiabá, como os Rios Coxipó e Aricá-Açu. Encontra-se limitada pelas escarpas estruturais do Planalto e em relevos acidentados, promovendo uma maior variação pedológica (solos litólicos, concrecionários e arenosos), razão pela qual, a mata é entremeada por Savana Arbórea Aberta e Savana Parque, indo até os limites dos sopés da morraria (com altitudes médias em torno de $300 \mathrm{~m}$ ) (Brasil, 1995).

A formação da Mata Semidecídua de interflúvio apresenta árvores com porte médio alcançando $20 \mathrm{~m}$ de altura, fuste retilíneo, formando dossel contínuo e emergente, que pode chegar até $30 \mathrm{~m}$ de altura. Nela se destacam quatro estratos: um, formado por indivíduos emergentes; outro logo mais abaixo em dossel contínuo; outro bem mais baixo; e um inferior, onde destacam-se adensamentos de Aráceas, Pteridófitas e cobertura herbácea. Uma particularidade que diz respeito à florística e estrutura da vegetação que compõe esse tipo de mata, é a existência de vegetação de domínio Amazônico, tais como : a jacareúba (Qualea ingens), uxirana (Calluphylum brasiliense), jatobá (Hymenia sp.), pau d'óleo (Copaifera langsdorffii), angelim amargoso (Vataireopasis speciosa), pombeiro (Tapirira guianensis), fava-anatã (Parquia multijuga) e tanimbuca-amarela (Buchenavia parviflora). Normalmente aparecem palmeiras como o buriti (Mauritia flexuosa), bacaba (Oenocarpus bacaba) e babaçu (Orbignya oleifera) (Brasil, 1995).

Outras espécies que merecem destaque são as justacontas (Sclerobirm paniculatum), (Dyospirus ericea), peroba (Aspidosperma sp.), Pouteria sp., Huminia sp., morototó (Didymopanax morototani), Tapinivia guianenais, ximbuva (Enterolobium tambori), almecega (Protium heptaphullum), Virola sebifera, Calophullum brasiliensis, 
ingazinho (Inga sp.), pindaiba (Xilopia sp.), cambará (Vochysia haenkeana) e carobaçu (Jacaranda sp.). As matas de interflúvio se constituem em verdadeiros refúgios florestais no meio de uma paisagem completamente aberta (Brasil, 1995).

2. As Matas ciliares variam conforme a posição topográfica, condições de solo e características de drenagem, ocorrendo em vales com canais de drenagem bem definidos. A mata semidecidua ciliar apresenta a composição florística definida por árvores altas (20 a 30 metros), que se mantém sempre verdes, tais como: Licania sclerophylla, Hertella gracilipes, ingá (Inga uruguensisi), Simarouba versicolor, cambará (Vochysia pyramidalis), Emmotuns nitens, Bysonima sp., Sclerobium paniculatum, pindaiba (Xylopia emarginata), Viola malmei, pombeiros (Tapirira guianensis), almecega (Protium almecega), Humira sp., pau-d'oleo (Copaifera langsdorff), Ficus sp., Chrysophyllumi sp. e Mabea ferruginea. A mata semidecidua de interflúvio geralmente estende-se na Chapada dos Guimarães em terrenos do Terciário (Cretáceo), em solos do tipo Latossolo Vermelho-Amarelo e Areias Quartzosas. Nas nascentes, onde a vegetaçăo é mais aberta, às vezes, aparecem renques de buritis (Mauritia flexuosa) (Brasil, 1995).

\section{III.2.5.2. Savana Arbórea Densa (Cerradão)}

O cerradão ocorre em faixas residuais nas áreas de cerrado (em capōes) e bordas da mata semidecídua (sobretudo a ciliar), apresentando na composição florística ,espécies xeromórficas, típicas de cerrado, e espécies ligadas às matas úmidas. Destacam-se as seguintes espécies nessa forma de vegetação: justacontas (Sclerobium paniculatum), olho-de-boi (Dyospirus sericea), Emmotum nitens, pombeiros (Tapiriva guianensis), Agonandra brasiliensis, pau-terra (Qualea grandiflora), faveiro (Peterodon polygaleofolius), almacegas (Protium heptaphyllum), timboeiro (Magnolia pubescens), cumbaru (Dipterix alata), pau-d'oleo (Copaifera langsdorfii), aroeira (Astronium urundeuva), jatobá (Hymeneae stigonocarpa), sucupira (Bowdichia virgilol), Hyrtella grandulosa, carvoeiro (Callisthene fasciculata) e muitas vezes aparecem bambuzais cuja espécie mais comum é Guadua paniculata (Brasil, 1995). 


\section{III.2.5.3. Savana Arbórea Aberta (Cerrado)}

Entre os indivíduos arbóreos do cerrado, os que mais se destacam são: pequizeiro (Cariocar brasiliense), faveiras (Pterodon polygaleofolius), embiruçu (Pseudobombax longiflorum), justacontas (Sclerobium paniculatum), sucupira (Bowdichia virgiloides), pau-terra (Qualea grandiffora e Qualea parviflora), muricis (Birsonia coccolobifolia e Birsonia crassifolia), lixeira (Curatella americana), pau santo (Kielmeyera coriacea e Kielmyera rubriffora), fruta de veado (Pouteria ramiffora), mangabeira (Harconia speciosa), Dimorphandra mollis, jacarezinho (Myrcia albotormentosa) e cagaita (Eugenia desinterica). Entre as subarbustivas destacam-se: Syagrus flexuosa, cajuzinho (Anacardium humile), Palicourea coriacea, Helictires sacarrolha, Cochlospermum regium, Cenostigma gardnerianum, araticum (Anona dioica) (Brasil, 1995).

\section{III.2.5.4. Savana Gramínea Lenhosa (Campo Sujo)}

Ocorre nas áreas de afloramentos rochosos. Podendo mudar gradualmente para "campo limpo" nos morrotes, onde o estrato herbáceo é predominante na fisionomia local, e para o "campo úmido", quando associado a solos hidromórficos, localmente caracterizados como várzeas. Quanto a florística é comum ocorrer o pau-terra (Qualea grandiflora), Ferdinandusa eliptica, semaneiras (Byrsonima crassiffora), muricis (Byrsonima coccolobifolia), para-tudo (Tabebuia caraiba), Cactáceas e Bromeliáceas, canela-de-ema (Vellozia flavicans), cambará (Vochysia petreae), renques de buritis, várias Orquidáceas, Briófitas e Pteridófitas, favorecidas pelos fatores condicionantes locais. (Brasil, 1995).

\section{III.2.5.5. Savana Parque (Campo Cerrado)}

Em determinados locais o cerrado passa para campo-cerrado, quando se observa na sua estrutura apenas dois estratos: um deles com uma média de altura de 1 a 4 metros; e o outro herbáceo, representado por gramineas e ciperáceas, freqüentemente entremeadas por representantes de Acantáceas, Genitáceas e Convolvulaceas. Esse tipo vegetacional ocorre em grande extensão do Parque Nacional e nas áreas adjacentes da Baixada Cuiabana (Brasil, 1995). 


\section{III.2.5.6. Campo Cerrado Rupestre}

Esse tipo vegetacional ocorre sobre afloramentos rochosos, em pequenas ithas de vegetação, acima dos $800 \mathrm{~m}$, possuindo distribuição restrita a poucas áreas do Parque Nacional, constituindo-se principalmente pelas seguintes famílias: Eriocaulaceae, Bromeliaceae, Iridaceae, Melastomataceae e Orquidaceae, cujos indivíduos não ultrapassam 1 metro de altura (Brasil, 1995).

\section{III.2.6. Fauna}

A fauna também apresenta-se muito variada. Destaca-se a grande variedade de insetos, que segundo Brown (1970) é a mais rica da região neotropical. A abundância de lepidópteros, torna-se importante elo da cadeia alimentar de um grande número de aves insetivoras, e de um grande número de mamíferos (Brasil, 1995).

A mastofauna presente no Parque é representada por diferentes espécies que normalmente ocorrem no pantanal, na amazônia e no cerrado, estando entre as mais representativas o lobo-guará (Chrysocyon brachyurus), espécie bastante importante controladora de populações de roedores, aves, répteis e insetos, além de dispersor de diversas espécies vegetais da qual se alimentam (IBAMA, 1989), encontrando-se no topo da cadeia alimentar e dependente do cerrado para sua alimentação e das matas para se abrigar (Brasil, 1995).

O veado-campeiro (Ozotocerus bezoarticus) é considerado pouco freqüente na área, habitando cerrado aberto e as veredas, tornando-se alvo fácil de caçadas em que se utilizam cães. A onça-pintada (Panthera onca), aparece em trânsito, na área do Parque, não se confirmando sua residência na área; também ocorrendo o gato-palheiro (Felis colocolo) que habita locais com gramíneas altas (Brasil, 1995).

O tamanduá-bandeira (Myrmecophaga tridactyla) e o tatú canastra (Priodontes giganteus), espécies ameaçadas de extinção, complementam seu alimento com as térmites. Porém, atualmente não têm sido observados rastros desses animais na área do Parque (IBAMA, 1989). 
Outros mamiferos comumente encontrados são a anta (Tapirus terrestris), o bugio (Alouta caraya), a rapozinha (Lycalopex vetulus), o cachorro-domato (Cerdocyon thous) e diversas espécies de roedores (Brasil, 1995).

Os principais representantes da herpetofauna são: o cágado (Phrynops vanrdehaegaei) e o jacaré-coroa (Paleosuchus palpebrosus) (Brasil, 1995).

A avifauna é representada por muitas espécies ameaçadas de extinção que se protegem nessa área, como é o caso do gavião-de-penacho (Spizaetus omatus), o socó-boi (Tigrisoma lineatum), a rolinha azul (Columbina cyanopsis) e o urubu-rei (Sarcoramphus papa) (Brasil, 1995). Também destaca-se a jacuguela (Pipile superciliaris), ave considerada rara e não mais avistada na área do Parque (Brasil, 1995).

$\mathrm{Na}$ área do Parque existem corredores de migração de aves (matas ciliares) e também barreiras geográficas, como no caso dos paredôes de arenito. Mas várias espécies são dependentes destes paredōes para nidificar, como os andorinhões (Cypseloides senex), a ararara vermelha (Ara chloroptera), a andorinha (Tachycineta leucorrhoa), entre outras (Brasil, 1995).

Os passeriformes como as pipiras (Pipira fascicauda e Antilophia galeta), os saís (Cyanerpes cyaneus e Tersina viridis), e o bicudo (Oryzoborus crassirostris) também são encontrados na área do Parque Nacional (Brasil, 1995).

O Parque é local de reprodução de várias espécies migratórias, como a tesourinha (Tyrannus savanna), o bigodinho (Sporophila lineola), o bem-te-vi rajado (Myodnastes maculatus) e o curiango (Nyctidromus albicollis) (Brasil, 1995).

\section{III.3. Ocorrência de Fenômenos Naturais e antrópicos e suas Conseqüências}

\section{Ocorrência de Fogo}

O Parque Nacional da Chapada dos Guimarães, localiza-se em região onde as condições geomorfológicas, de vegetação e de clima, propiciam a ocorrência de fogo natural, cuja ação é intensificada pela ação antrópica. Nos meses frios, a 
baixa precipitação aliando-se aos ventos frios originários do Andes, tornam a vegetação um material combustivel em potencial, especialmente a vegetação rasteira dos cerrados, cerradões e campos sujos. Os proprietários, nessa época, manejam, tanto suas pastagens nativas, como preparam o terreno para outras atividades agrícolas, utilizando-se do fogo, sem os devidos cuidados, para evitar a sua disseminação, causando incêndios dentro do Parque e no seu entorno.

Existem outras atividades que provocam incêndio na área, destacandose: a) o garimpo (causador de um grande incêndio em 1994), onde o fogo foi promovido para o aumento do raio de ação de aparelhos que detectam o ouro; b) o umbandismo, deixando na área de suas atividades religiosas grande quantidade de velas acesas; c) os churrascos, em churrasqueiras improvisadas no chão, comuns entre os visitantes de finais de semana; d) caça esportiva e predatória; e) fumantes que lançam tocos de cigarros às margens da Rodovia MT 251; e) também os piromaníacos, que levam caixas de fósforo, para colocarem fogo na vegetação a título de entretenimento. Em algumas situações a causa do fogo é atribuída a fenômenos naturais, como as descargas elétricas.

\section{III.4. Características sócio-econômicas e culturais da UC}

\section{III.4.1. Situação Fundiária}

A expectativa de criação do Parque e a suposta indenização levou e continua levando muitos proprietários a construírem inúmeras benfeitorias, com a intenção de elevar o valor das respectivas propriedades. Atualmente uma parte considerável do Parque Nacional está ocupada por chácaras de lazer com imóveis suntuosos (Brasil, 1995).

O cadastramento das propriedades localizadas no interior do Parque, teve início em 1990, sendo identificados na época 122 imóveis, pertencentes a 106 proprietários com título de posse e 10 posseiros (Brasil, 1995).

O processo indenizatório teve início ainda em 1990, com a aquisição de duas propriedades; a Fazenda Pombal com 205,74 ha, e toda a sua infra-estrutura e a Fazenda Véu de Noivas com 408,40 ha, mas até hoje não está totalmente 
administrada pelo IBAMA, pois as suas benfeitorias não foram indenizadas, que são os restaurantes Véu de Noiva e Cachoerinha. (Figura 33).

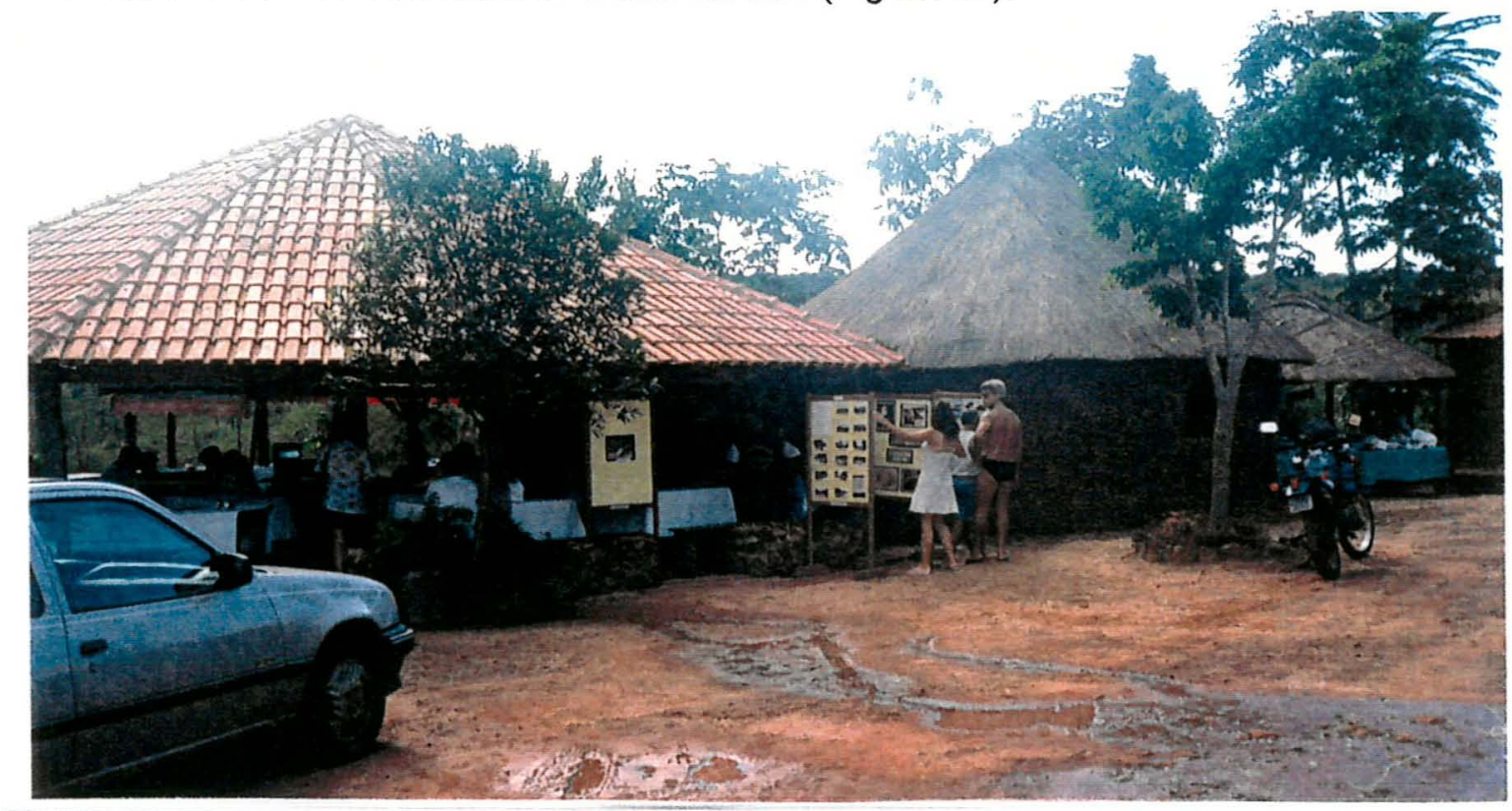

Figura 33 - Restaurante Véu de Noiva no PARNA da Chapada dos Guimarães.

A Fazenda Santa Rita de Cássia, com uma área de 718,52 ha e suas benfeitorias, foi indenizada em 1992, porém não administrada pelo IBAMA, pois seu processo de desapropriação desapareceu no trajeto da sede do IBAMA para a Superintendência/MT, impedindo assim a posse dessa área (Brasil, 1995). Observar a figura 35 .

Ainda em 1992, segundo informações do Presidente da Associação da Gleba do Rio Claro e Mutuca, em uma das propriedades da Empresa FIBRA Empreendimentos Imobiliários, existiam cadastrados 45 invasores, não constantes no primeiro cadastro (Brasil, 1995).

A Comissão Institucional para seleção, levantamento e plotagem das áreas do PARNA de Chapada dos Guimarães" foi instituída em 1994", com a participação do IBAMA, INCRA, INTERMAT (Instituto de Terras de Mato Grosso), colaboradores da ARCA (Associação para Recuperação e Conservação do Ambiente), região escoteira de Mato Grosso, obtiveram toda a malha fundiária e critérios prioritários para subsidiar a indenização de 09 propriedades, totalizando 4.685,19 ha. Dentre elas: 1) Armação Mutuca, considerado ponto estratégico para o 
controle das atividades do Parque, pois localiza-se numa das extremidades deste e em área adjacente à Rodovia MT 251, totalizando 5,08 ha. Observar figura 34.

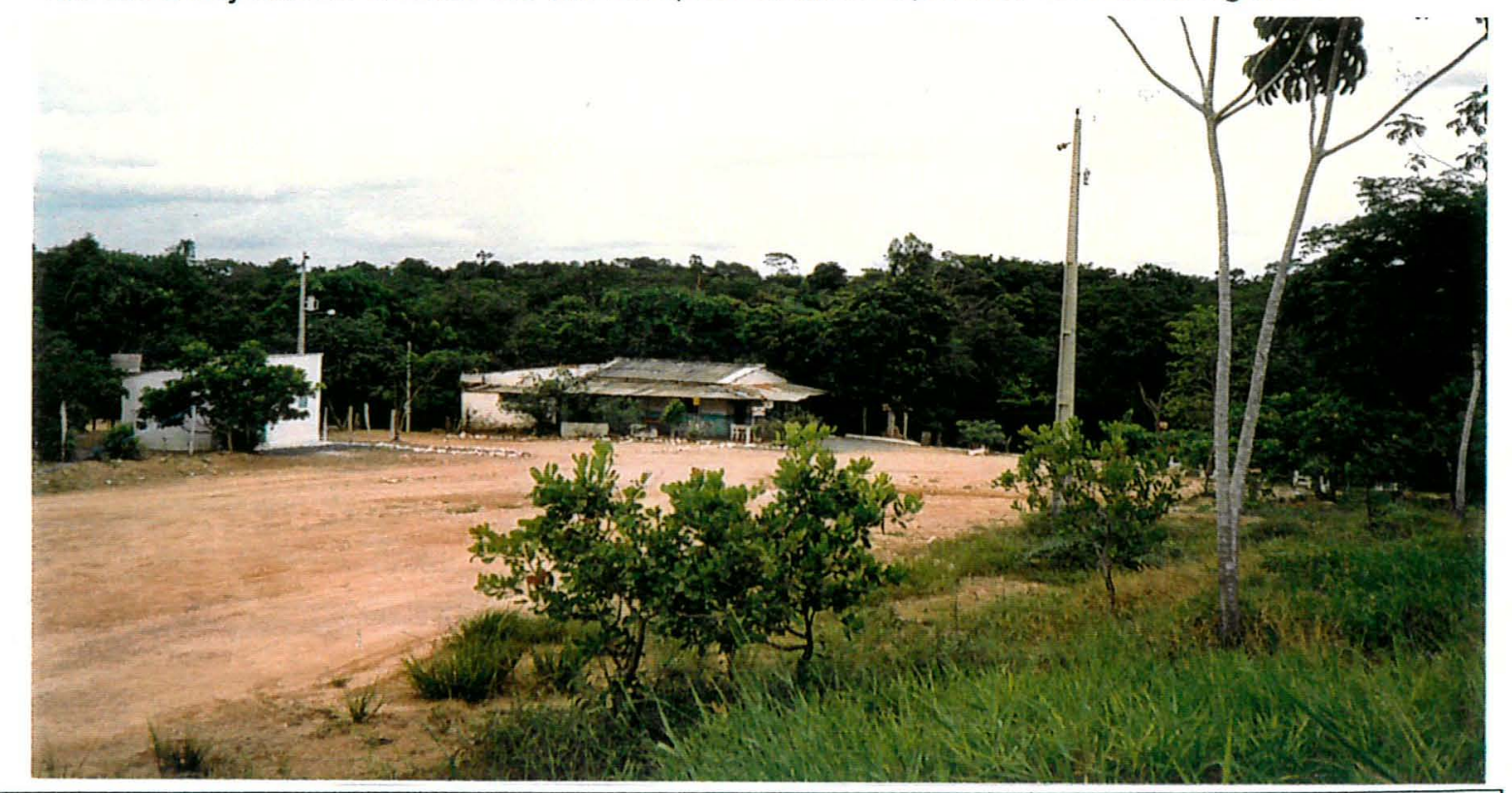

Figura 34 - Vista das proximidades do Rio Mutuca.

2) A Fazenda Gorgonha, com área de 73 ha, por possuir mananciais e vegetação de cerrado visivelmente pouco alterada, pela ação antrópica, além de ser contígua a aproximadamente 2.199 ha de área devoluta; 3) a Estância Planalto com uma área de 65 ha, que possui grande valor arqueológico, histórico e cultural por conter formações como o Chapéu de Sol, o Abrigo das Abelhas, o Morro de São Jerônimo e o Jacaré de Pedra; caminhos tropeiros denominados de Magessi, Carretão e Quebra Gamela. Abriga a cabeceira do Rio Aricazinho, que é um dos formadores do Rio Cuiabá. Esta área possui formações de savana, campo rupestre e matas de Encosta (Bocainas), que são habitadas por várias espécies ameaçadas de extinção, entre elas o veado campeiro (Ozotocerus bezoarticus) e a rolinha azul (Columbina cyanopsis): 4) no Córrego Paciência, foram adquiridos 03 lotes totalizando uma área de 9,45 ha, em sua maioria constituído por veredas (áreas fragilíssimas) e local bastante procurado pelos visitantes em decorrência da proximidade com o Terminal Turístico da Salgadeira (que não faz parte do Parque Nacional na sua totalidade, mas com a maior parte da área pertencente a APA Estadual da Chapada dos Guimarães); 5) a Fazenda Cristal com área de 994 ha contígua a outros imóveis da União, e constituída por monumentos arqueológicos e 
geomorfológicos, além de grandes áreas de Savana em processo de recuperação (Brasil, 1995). Observar figura 35.

Além destes imóveis, foram adquiridos da FIBRA Empreendimentos Imobiliários, dois imóveis totalizando $3.547,76$ ha, contíguos a áreas, em processo de regularização, onde encontram-se diversos mananciais e habitats de espécies ameaçadas de extinção (Brasil, 1995).

Dos imóveis indenizados em 1994, o IBAMA, recebeu documentação de posse da Justiça, restando o prazo de recurso judicial que venceu em 30 de novembro de 1995, para a emissão definitiva dos Títulos em nome da União (Brasil, 1995).

A Fazenda Quilombo, vizinha da Fazenda Pombal, encontra-se em processo de análise para efeitos de desapropriação, desde 1990, quando o proprietário se retirou da área. Contudo o processo não foi adiante devido a evidência de supervalorização das terras e benfeitorias, que atualmente se encontram abandonadas (Brasil, 1995).

No ano de 1995, com as indenizações realizadas, e juntamente com áreas devolutas da União, foi possível fechar um polígono de áreas de posse do IBAMA, facilitando assim o processo de implantação do Parque Nacional. Mas para tal, faltou a indenização necessária das benfeitorias (Brasil, 1995).

Atualmente o Parque possui $18,47 \%$ de área indenizada, além de mais $17,37 \%$ que pertencem à União, totalizando assim $35,84 \%$ da área total do Parque. Os $64,16 \%$ restantes se encontram nas mãos de seus proprietários, que utilizam as terras para fins diversos (Brasil, 1995).

A demarcação dos limites do Parque foi executada através de convênio com a Prefeitura Municipal da Chapada dos Guimarães, sendo colocado um marco em cada ponto, porém muitos deles estão necessitando de reaviventação (Brasil, 1995).

\section{III.4.2. Uso do Parna}

O Parque Nacional da Chapada dos Guimarães encontra-se ainda em processo de desapropriação, apesar de ter sido criado em 1989, e não possuir ainda 
seu Plano de Manejo, sendo nele desenvolvidas muitas formas de usos incompatíveis:

Figura 35 - Situação Fundiária do PARNA da Chapada dos Guimarães

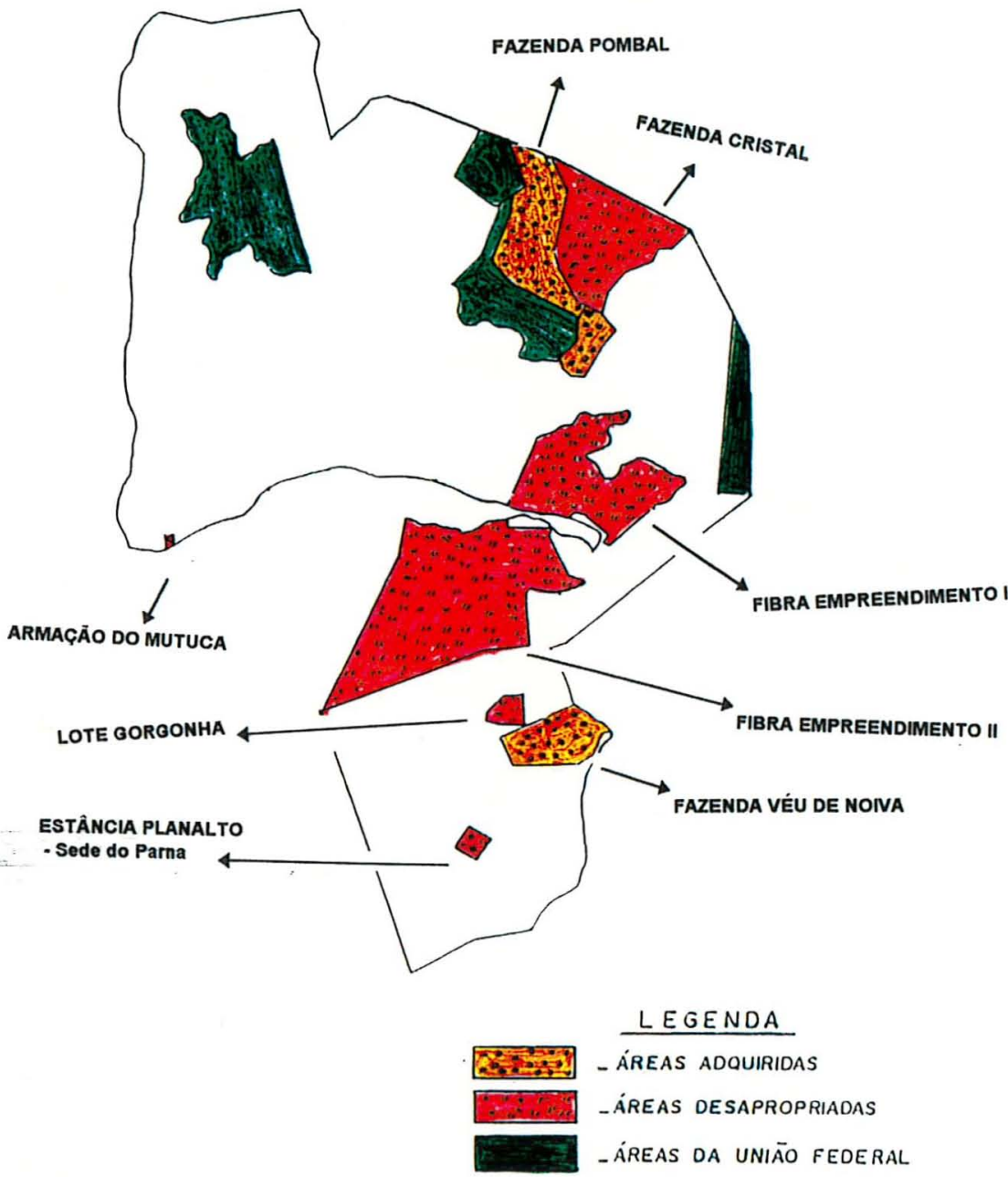

Fonte: Adaptado do PAE de Chapada dos Guimarães, 1995. 


\section{III.4.2.1. Uso pelo visitante}

A cidade de Chapada dos Guimarães, com seu clima ameno, além de sua proximidade com a capital, possui inúmeros pontos de atração turística, como sítios arqueológicos, monumentos históricos, belissimas cachoeiras, atraindo nos finais de semana e em especial nos períodos de eventos promovidos na cidade, inúmeros visitantes locais, nacionais e até turistas internacionais (figura 36). Algumas empresas de turismo das cidades de Chapada e Cuiabá, promovem excursões ao Parque Nacional, com roteiros e públicos variados.

A maior procura do Parque Nacional, com visitação orientada, ocorre normalmente nos períodos de férias letivas, onde pode-se observar até uma quadruplicação em relação ao período de baixa temporada (Brasil, 1995).

Apesar do potencial turístico evidenciado, o controle da visitação por parte do Parque fica bastante dificultado, tendo em vista que este é cortado pela MT 251 e suas ramificações, além do que a Unidade não possui nenhuma guarita de controle de visitantes.

Algumas amostragens incipientes, realizadas em 1994, no período de carnaval evidenciaram que o ponto de maior visitação foi a "Casa de Pedra", seguida pela "Cachoeira Véu de Noivas", "Cachoerinha", "Mata Fria" e "Rio Claro" (Brasil, 1995).

A grande visitação no Rio Paciência, local de fácil acesso e grande beleza, pode resultar em perdas irreparáveis para a natureza, por ser ambiente de grande fragilidade e da existência de espécies raras e ameaçadas de extinção. Esses locais já tiveram seus acessos obstruidos, mas os visitantes desobstruem e depredam as placas proibitivas. Acampam em algumas áreas indevidas; estacionam em locais não propícios, muitas vezes abusando do volume de seus rádios, desrespeitando a natureza local e afugentando a fauna, destruindo a vegetação, e deixando muito lixo acumulado, mesmo com a existência de lixeiras em alguns pontos, que são limpas

quase que diariamente pelo Diretor do Parque Nacional, mesmo não sendo sua função.

$\mathrm{Na}$ área do Parque proibe-se a realização de churrascos com fogueiras. O trabalho de fiscalização é realizado pelo Diretor do Parque, praticamente sozinho 
nos finais de semanas, quando aumenta a demanda. Aparentemente parece ter diminuído a realização dessa atividade próxima à rodovia, mas nas regiões de difícil acesso essa vigilância é dificultada, também pela incompreensão do visitante, que vê $a$ área onde tudo é permitido e não como uma Unidade de Conservação.

A fiscalização da área tem sido realizada de forma incipiente e não sistemática e nos períodos de maior visitação conta com o auxilio de um grupo da Policia Militar e agentes de Defesa Ambiental da SUPES/MT e a participação do grupo de voluntários da ARCA.

\section{III.4.2.2. Usos Conflitantes}

Loteamentos - Dentro da Sesmaria Mutuca, numa área de $1.011,00$ ha, pertencentes à FIBRA Empreendimentos Imobiliários, foram desmembrados 75 lotes distribuídos pelos Rios Mutuca e Claro e córregos Porteira, Paciência e Salgadeira, com posterior construção de infra-estrutura e ocupação. Atualmente existem denúncias de vendas de lotes por parte da Imobiliária Rio Azul, nas cabeceiras do Rio Mutuca, área que também pertence à Sesmaria Mutuca (Brasil, 1995). (Figura 35).

Garimpo de ouro - Realizado de forma manual e esporádica, nas proximidades do Rio Coxipó, causando o desmatamento de suas margens e conseqüente assoreamento desse corpo dágua (Brasil, 1995).

Drenagem de veredas - do Rio Claro, com a abertura de grande quantidade de valas, para a construção de campo de futebol e tanques de piscicultura.

Barramento dos leitos dos córregos - principalmente no Rio Claro, onde ocorrem as invasões, para a construção de "piscinas" de lazer.

Realização de cultos religiosos - Cujos rituais são praticados em cachoeiras e margens de rios.

Coleta de plantas medicinais - Tais como a carobinha, douradinha, para-tudo, barbatimão; também frutos do pequi e buriti; palmitos da gariroba, além de serem realizadas a caça e pesca furtivas. 
Apiário - Instalado em 1993, localizado nas imediações do "Portão do Inferno" contrariando o parecer técnico e jurídico do IBAMA.

Chácaras de lazer - Os ocupantes dessas chácaras fazem suas construções, trazendo seus animais domésticos e plantas exóticas, também desenvolvendo agricultura em pequena escala, para tanto desmatando e queimando a área.

Pecuária - A criação de gado ocupa uma importante área dentro do PARNA. A Fazenda Chafariz, localizada ao norte, possui uma área de 4.000 ha, dentro do Parque, ocupada por pastagem artificial onde se utilizou fogo após o desmatamento, para a manutenção de 1.500 cabeças de gado de cria, o que causa muito pisoteio e degradação da área, verificando-se vários pontos de erosão. Para a manutenção dessa atividade, são construídos açudes e cercas. A fauna nativa está comprometida por competição pelo espaço, alimentação e pela transmissão de doenças de animais domésticos.

A existência da rodovia MT 251 e suas ramificações, que corta e margeia o Parque Nacional, facilitam o acesso de veículos a praticamente toda a área, onde áreas frágeis ficam vuineráveis, colocando em risco sua integridade como unidade de conservação. É uma rodovia sem acostamento, de acesso a vários Municípios, possuindo alta rotatividade, principalmente nos finais de semana, causando o atropelamento de muitos animais, como vários acidentes fatais (Brasil, 1995).

\section{III.4.3. Valores Culturais}

A ocorrência de sítios arqueológicos e históricos, foi um dos atributos para a criação do Parque Nacional, que os abriga tanto no seu interior como no seu entorno. Esse patrimônio vem sofrendo depredações e atos de vandalismo, sem mesmo terem sido estudados. Os sítios apresentam-se sobre a forma de abrigos de rocha e oficinas líticas, com pinturas e gravações rupestres, citando entre outros: "Letreiro dos Bugres", "Pedra Preta", "Pata de Onça", "Chapéu de Sol", "Casa de Pedra", "Bicho Morto", "Ponta do rio Claro" e o "Morro de São Jerônimo". Os caminhos tropeiros coloniais do Rio Coxipozinho, Quebra Gamela, Carretão, Magessi e "Tope 
de Fita", que tiveram importância durante o período colonial, podem ser utilizados como futuras trilhas de interpretação (Brasil, 1995).

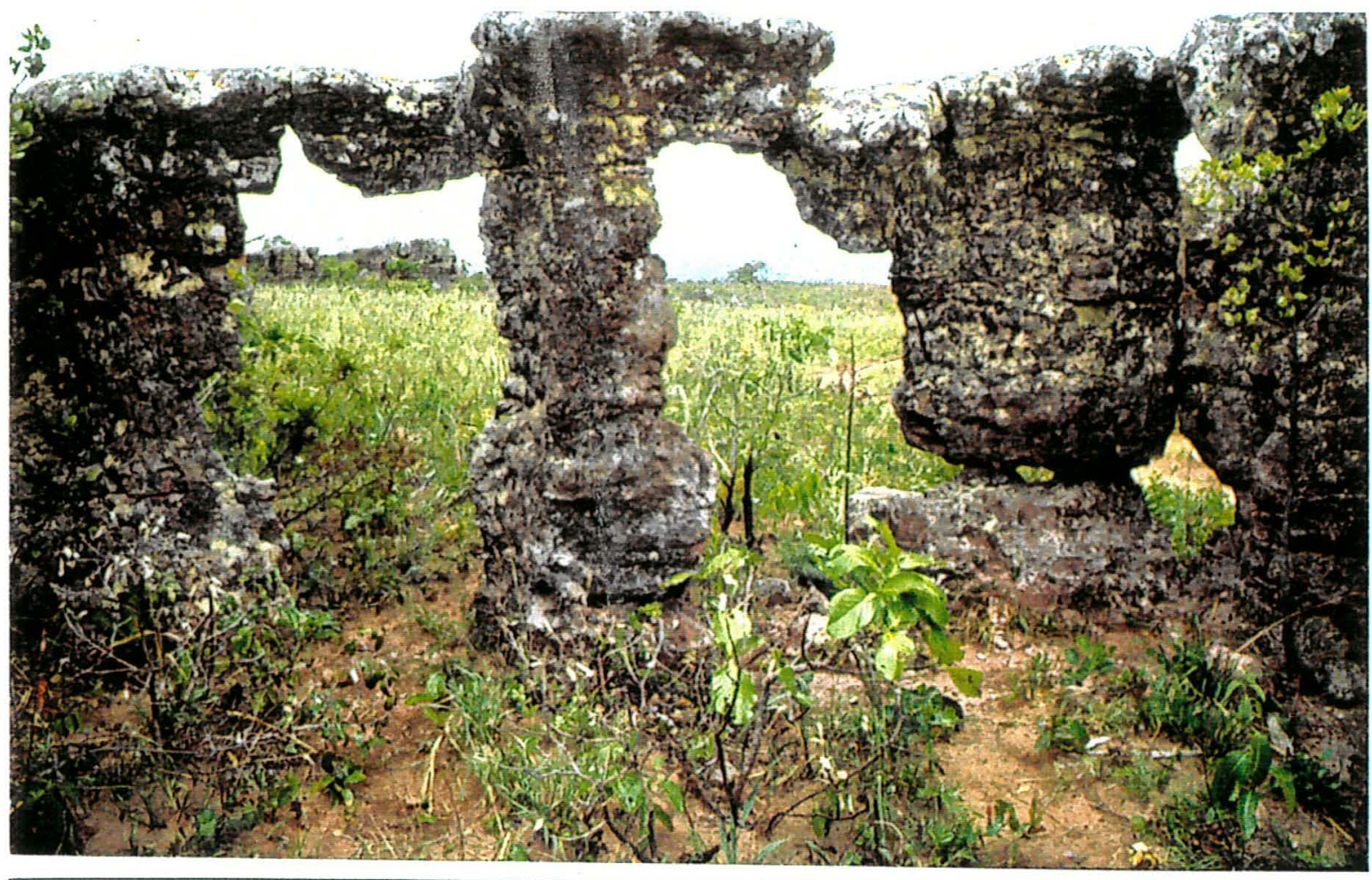

Figura 36 - Aspecto de uma das inúmeras formações rochosas do PARNA.

\section{III.5. Área de influência da UC}

\section{III.5.1. O Município de Chapada dos Guimarães}

O Município de Chapada, já foi o maior Município em área do Brasil com $204.304 \mathrm{~km}^{2}$, possui hoje $6.494,02 \mathrm{~km}^{2}$, contando com uma população de 8.812 habitantes, sendo que a maior parte encontra-se na zona rural. A distribuição populacional justifica-se em parte, pela existência de algumas vilas, povoados, distritos, por um significativo número de pequenos produtores e pela pouca oferta de empregos na área urbana.

A agricultura no Município de Chapada é bastante diversificada, cultivase soja, milho, arroz, feijão, hortaliças e frutas. O sistema de exploração do pequeno produtor permanece o mesmo de anos atrás, como a roça de toco, plantio manual, uso de sementes impróprias, vindo todos esses fatores a refletir negativamente na 
produtividade e na qualidade do produto. A falta de investimentos no setor prejudica as ações da empresa responsável pelo setor (EMPAER, 1996c). O grande produtor planta soja, milho, milho safrinha e arroz.

A Pecuária é uma atividade estabelecida, mas não no seu potencial como um todo. Poucos produtores demonstram-se acessiveis às recomendações técnicas, como inseminação artificial, manejo de pastagens, controle de endo e ectoparasitas. A maioria dos pequenos criadores tem dificuldades de investir na pecuária por falta de recursos (EMPAER, 1996c).

A cidade se encontra no entorno da UC, distando $9 \mathrm{~km}$ da sede do Parque, e contribui para a contaminação das nascentes do Córrego Monjolinho, mantendo aterro sanitário e depósito de lixo doméstico e hospitalar nas suas cabeceiras, sendo este córrego afluente do Rio Coxipó, o principal formador da rede hidrográfica do Parque Nacional. No Município existe a extração de ouro e diamantes, e aparentemente essas atividades têm diminuido em função da pressão dos Órgãos Ambientais.

No Municipio existem duas rodovias estaduais, que são a MT 251 (Cuiabá-Chapada) e a MT 305 (Chapada-Nova Brasilandia-Campo Verde); 04 hotéis, 09 restaurantes, 02 pousadas e pensões, com um total de 420 leitos e 02 campings. Recebe aproximadamente 6.000 pessoas por dia quando da realização do Festival de Inverno. Oferece também, outras festas populares, como a festa da ponte de São José, festival do Chopp, Rally de Jeep e bicicletas, entre outras (Brasil, 1995; EMPAER, 1996c).

\section{III.5.2. Municipio de Cuiabá}

Cuiabá, localizada na Baixada Cuiabana, às margens do Rio Cuiabá, com área de $3.224,37 \mathrm{~km}^{2}$, possui uma população de 508.167 habitantes, dos quais a grande maioria se distribui na zona urbana. A base econômica do Município é o setor terciário, absorvendo $69,69 \%$ da população economicamente ativa, onde se destacam as atividades de prestação de serviços $(23 \%)$ e comércio de mercadorias $(15,89 \%)$. 0 setor secundário absorve 22,84 \% da população economicamente ativa, sendo que se destaca a indústria de construção com 10,77\%. O setor primário absorve apenas $7,47 \%$ da população economicamente ativa, sendo representada basicamente por 
pecuária de corte e leite e também pela suinocultura. Apresenta grande significado na economia e na renda básica da cidade, a administração pública federal, estadual e municipal (EMPAER, 1996c).

O Município está localizado numa posição estratégica, fazendo parte de planos de integração nacional, figurando a construção de importantes eixos rodoviários, como a BR 070 que liga Brasília a San Matias (Bolívia); Br 364 ligando Goiânia a Porto Velho e a BR 163 que liga Campo Grande a Santarém e dentre as rodovias estaduais a MT 251 que liga Cuiabá a Chapada dos Guimarães (Brasil, 1995).

Possui clima tropical úmido com altas temperaturas, cujas médias máximas atingem valores em torno de $34^{\circ} \mathrm{em}$ decorrência da topografia, e altitude de 165 metros.

O transporte aéreo é realizado pelas empresas Varig, Vasp; Transbrasil; Tam, Taba, ligando Cuiabá com os demais centros do País, bem como a conexão com vôos internacionais.

A sede do Municipio conta com infraestrutura razoável, um sistema de saneamento básico precário e abastecimento de energia realizado pelas usinas Casca I, II, e III e pela aquisição de energia da Eletronorte vinda de Cachoeira Dourada (GO), através de sistema interligado com o sudeste.

A pecuária constitui-se essencialmente pelo gado de corte seguido pelo gado de leite e suinos. A agricultura é representada basicamente pelas culturas de arroz, milho, mandioca (potencial a ser incrementado). A produção hortigrangeira apresenta-se como importante alternativa para mini e pequenos produtores, devido à existência de inúmeras espécies de produtos adaptados às condições climáticas e ambientais. A produção agrícola, atividade pesqueira e a psicultura representam um potencial de grande efeito econômico e de apoio à conservação ambiental (EMPAER, 1996c). 


\section{III.6. Aspectos Institucionais}

\section{III.6.1. Infra-Estrutura}

Dentre os imóveis indenizados, o Parque Nacional, conta com as seguintes construções: 1) Estância Planalto, sede administrativa e residência do Chefe da Unidade, construção de $100 \mathrm{~m}^{2}$, em madeira, 02 quartos, varanda, água, mobília e sem eletricidade, recém-reformada. Figura 37.

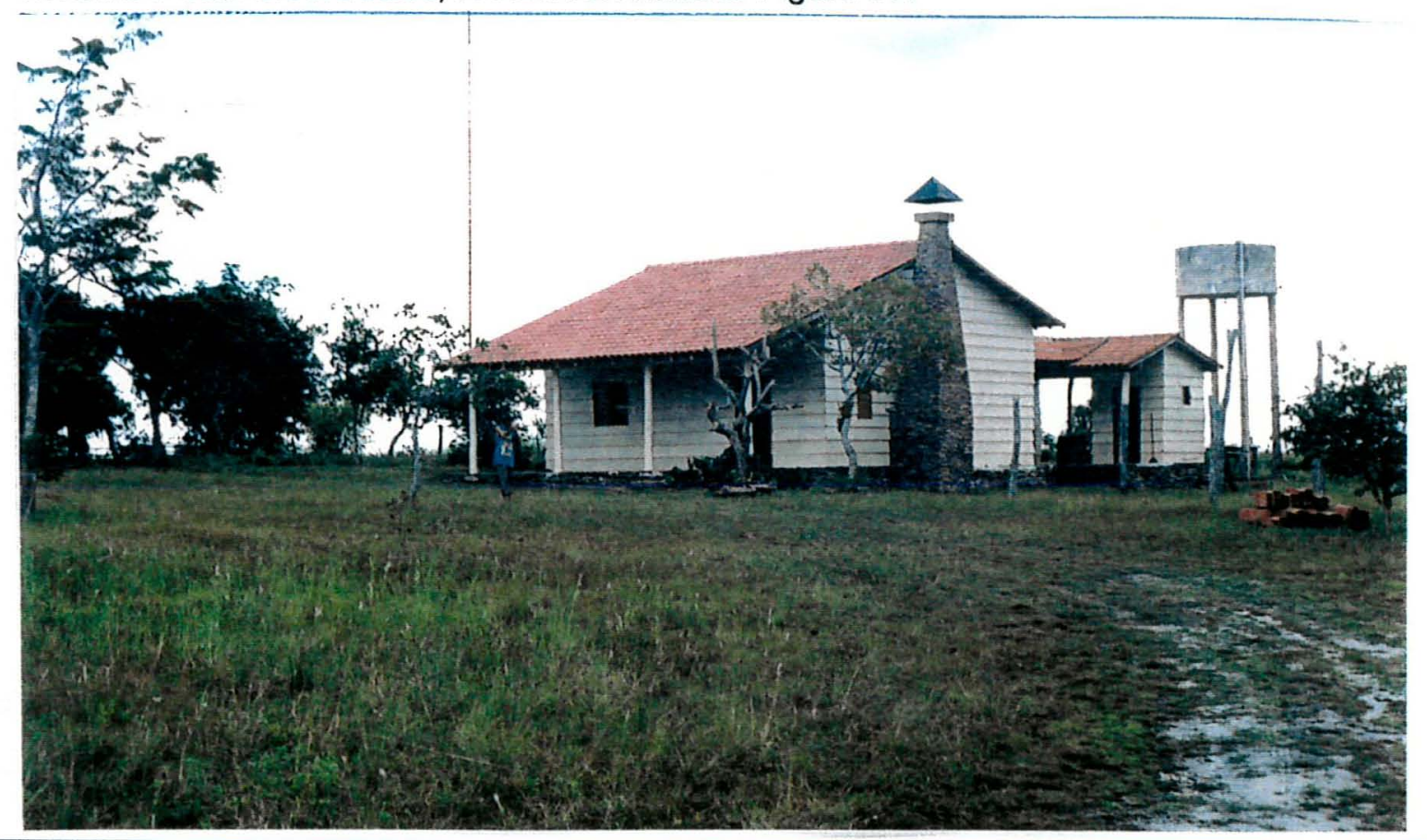

Figura 37 - Aspecto da sede atual do Parque Nacional de Chapada dos Guimarães.

2) Fazenda Pombal, sobrado em alvenaria, com $322 \mathrm{~m}^{2}$ de área construída, 03 quartos, 03 banheiros, cozinha, sala, varanda, churrasqueira, área de serviço, água de poço artesiano e eletrificação por gerador. Galpão de alvenaria e casa do funcionário, construção de $50 \mathrm{~m}^{2}$. Ambas construções recém-reformadas (Vide figura 38).

3) Presbitério, sem uso, com $404 \mathrm{~m}^{2}$, de alvenaria, com salão, refeitório e 02 quartos. 4) Fazenda Cristal, atualmente sem uso, construção em madeira, com $100 \mathrm{~m}^{2}, 03$ quartos, banheiro, cozinha e varanda. 


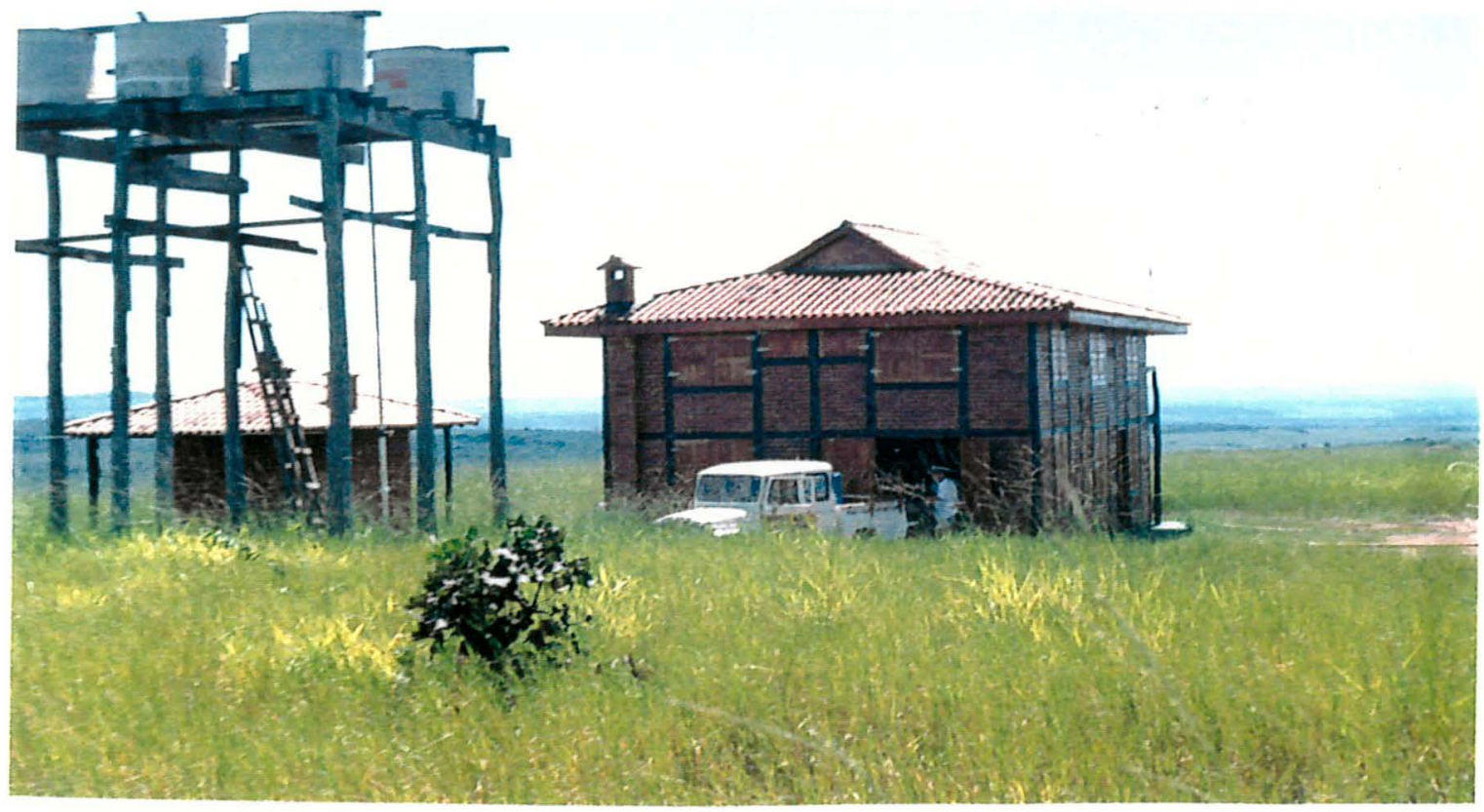

Figura 38 - Vista geral da sede da Fazenda Pombal.

Os imóveis descritos abaixo, foram adquiridos em 1993 e 1994 e ainda não estão sob domínio do PARNA: 5) Fazenda Santa Rita de Cássia, usada por terceiros, com 203,31 $\mathrm{m}^{2}$, de alvenaria, com 02 suítes, 01 quarto, banheiro, sala, cozinha, varanda e área de serviço. Não possui luz nem água. Também possui 01 galpão de $200 \mathrm{~m}^{2}$ e um barracão, com $60 \mathrm{~m}^{2}$, ambos usados por terceiros. 06) Lote Gorgonha, casa de alvenaria e barraco de madeira, usado por terceiros. 07) Armação do Mutuca, bar de alvenaria e camping, possuindo água e eletrificação (Brasil, 1995) 


\section{III.6.2.Pessoal}

Tabela 04 - quadro de pessoal do PARNA de Chapada dos Guimarães

\begin{tabular}{|c|c|c|c|c|}
\hline Função/Cargo & $\begin{array}{l}\text { Portaria / } \\
\text { Nomeação }\end{array}$ & $\begin{array}{c}\text { Anol } \\
\text { nascimento }\end{array}$ & Escolaridade & Cursos/área \\
\hline 1.Chefe do Parque & $\begin{array}{c}\text { Portaria 481/95 } \\
\text { de } 20 / 03 / 95\end{array}$ & 1954 & $\begin{array}{l}\text { Superior } \\
\text { incompleto }\end{array}$ & $\begin{array}{l}\text { Formação de Brigadas } \\
\text { de Combate a Incêndios } \\
\text { Florestais }\end{array}$ \\
\hline $\begin{array}{l}\text { 2. Motorista oficial* } \\
\text { Chefe Substituto }\end{array}$ & $\begin{array}{l}\text { Decreto } 12 / 09 / 91 \\
\text { Portaria } 1765 / 93\end{array}$ & 1958 & $\begin{array}{l}\text { I Grau } \\
\text { completo }\end{array}$ & $\begin{array}{l}\text { I Curso de Fiscalização } \\
\text { em Unidade de Conser- } \\
\text { vação - Serra do Cipó- } \\
\text { MG/95 }\end{array}$ \\
\hline 3. Pesquisador & Diploma 1821/94 & 1960 & Superior & \\
\hline
\end{tabular}

* Oriundo da FNS (Fundação Nacional de Saúde), através do Decreto Presidencial de 10/09/91, aproveitado para o quadro do IBAMA através do telex 1335-BSB.

** Redistribuido da FUNAI, número do Diploma 1821/94.

*** III Curso de Planejamento e Legislação em Unidade de Conservação. Ilhéus - Bahia. 23/06/1997 à 04/07/1997. Promovido pelo DIREC /IBAMA / PNMA

\section{III.7.Considerações}

Um dos maiores problemas do Parque Nacional de Chapada dos Guimarães é o fundiário, seguido dos incêndios que muitas vezes são ocasionados pela ocupação no interior do Parque, em função da falta de regularização fundiária.

Nem sempre o fogo tem essa origem, podendo ter causas variáveis, mas impondo severas perdas de biodiversidade todos os anos nessa Unidade de Conservação.

Após a criação do Parque Nacional, essa área tem sofrido intensa especulação imobiliária, dando a nítida impressão que esses fatos são causados pela expectativa de futuras de indenizações.

O Parque Nacional é praticamente urbano, devido a sua proximidade com a capital, donde afluem muitos "turistas de final de semana", que na sua grande 
maioria desconhece que existe e até mesmo o que seja uma Unidade de Conservação e outros que fazem questão de desconhecer o fato, mesmo havendo um trabalho ainda incipiente de conscientização .por parte do Órgão gestor e outras entidades, principalmente da Ong ARCA, que atuam na área.

Mesmo tendo sido criada a APA de Chapada dos Guimarães gerida pela FEMA, o uso público desordenado se faz notar principalmente na região do "Complexo da Salgadeira", gerando grandes transtornos no entorno do Parque.

A forma e o tamanho da Unidade dificultam o trabalho dos dois funcionários na fiscalização dos quase 33.000 hectares, necessitando de aumento nesse número à nível qualitativo e quantitativo.

Outros usos conflitantes como loteamentos, garimpo de ouro, drenagem de veredas, desmatamentos, barramento de córregos, realização de cultos religiosos, coleta de plantas medicinais, presença de apiário sob a estruturas geológicas, pecuária em seus limites e a existência de uma rodovia e suas ramificações completam o quadro de problemas dessa Unidade de Conservação.

O Parque conta com infra-estruturas recém reformadas, estando preparada para receber pesquisadores, mas parece existir ainda um fraco intercâmbio entre as Instituições de Pesquisa e o IBAMA, associada a inexistência de uma política de pesquisa para Unidades de Conservação. 


\section{IV.ESTAÇÃO ECOLÓGICA DE TAIAMÃ}

\section{IV.1. Situação Histórica E Geográfica}

\section{IV.1.1. Localização e Limites Atuais}

A Estação Ecológica de Taiamã, está situada no Município de Cáceres, na bifurcação do Rio Paraguai com o Rio Bracinho.

A Estação Ecológica de Taiamã, foi criada pelo Decreto Federal $n^{0}$ 86.061 de 02 de julho de 1981, com área de 11.200 ha, sendo a llha de Sararé incorporada posteriormente à Estação.

Possui as seguintes coordenadas geográficas: $16^{\circ} 48^{\prime} 5^{\prime \prime}$ e $16^{\circ} 56^{\prime} 46^{\prime \prime}$ de latitude sul e $57^{\circ} 42^{\prime} 56^{\prime \prime}$ e $57^{\circ} 37^{\prime \prime} 43^{\prime \prime}$ de longitude W. Com uma área total de 16.000 ha. É formada pelas llhas de Taiamã e Sararé, circundada a esquerda pelo Rio Bracinho e a direita pelo Rio Paraguai.

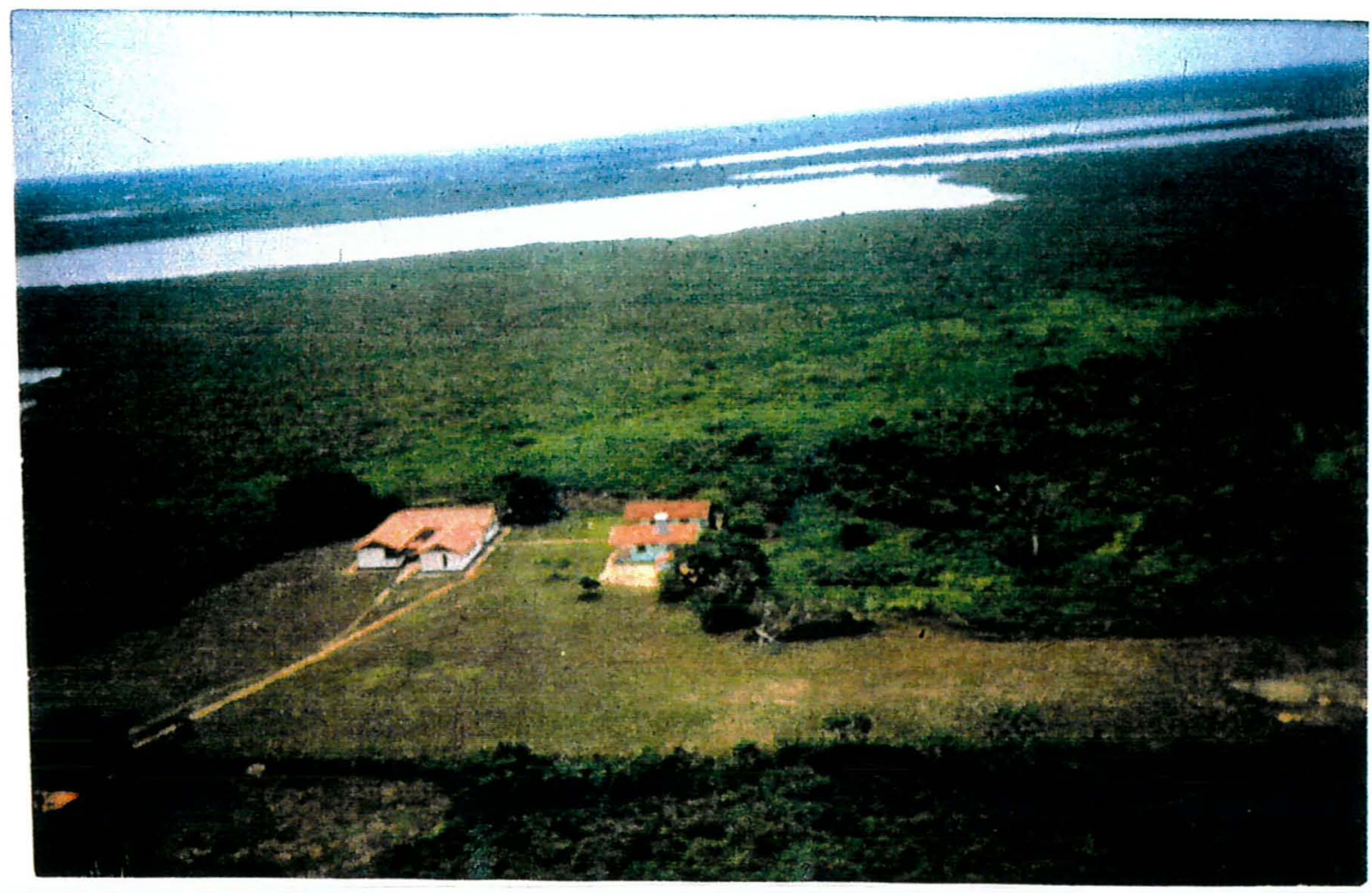

Figura 39 - Aspecto da sede e parte do campo de pouso da Estação Ecológica do Taiamã. 


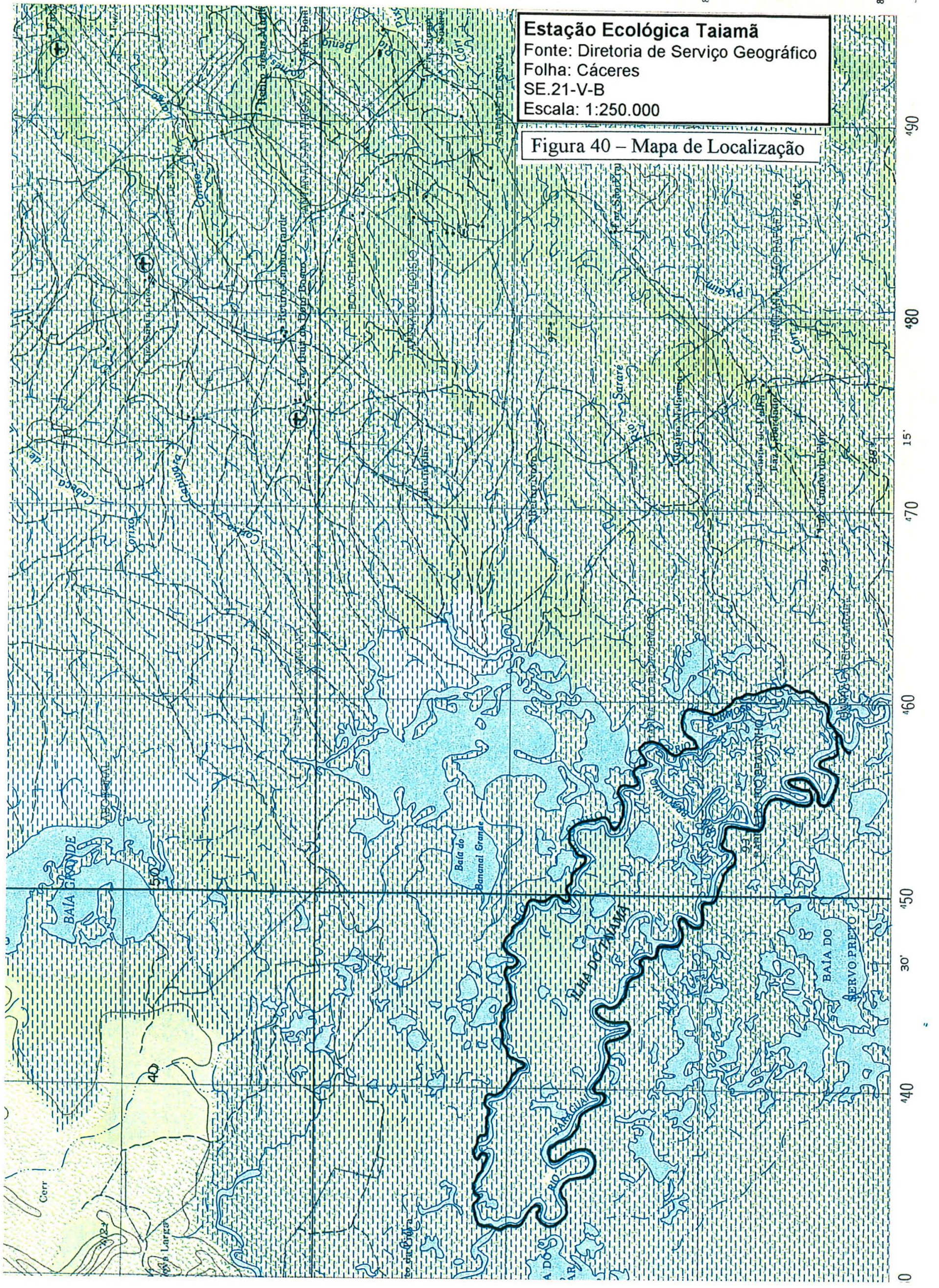




\section{IV.1.2 Vias de acesso}

A Estação Ecológica é acessivel por via fluvial. Existe uma via de acesso, partindo-se de Cuiabá, por rodovia asfaltada (BR 364) num percurso de 230 $\mathrm{km}$ até Cáceres, que dista $100 \mathrm{~km}$ até a sede da Estação, descendo-se pelo Rio Paraguai. Na Estação, um dos possíveis meios de locomoção é o fluvial. No acesso por via aérea, pode-se utilizar o campo de pouso da Estação, ao lado da sede. (Vide figura 39).

\section{IV.1.3. Histórico da Unidade de Conservação e antecedentes legais}

Em reunião realizada em 02 de setembro de 1977 na cidade de Poconé/MT, o Capitão Carlos G. Correia da Silva, oficial da Marinha, fez uma palestra sobre a região, explicando que havia uma itha no Rio Paraguai, de domínio da União, disponível para fins conservacionistas. $\mathrm{Na}$ época, a diretora dos Parques Nacionais do IBDF, Maria Tereza Jorge Pádua, achou a itha demasiadamente pequena (cerca de 12.000 ha), e não demonstrou interesse pela área. O Dr. Paulo Nogueira Neto, também presente na reunião, procurou sem demora o Comandante, para saber mais detalhes sobre a ilha disponível. Constatando-se a exatidão das informações, procurou-se logo tomar posse do legado. Porém, haviam 05 posseiros, que trabalhavam para um pecuarista, que mantinha ali, muitas cabeças de gado. $O$ gado foi retirado da ilha, e os posseiros indenizados. As benfeitorias foram avaliadas e as indenizações pagas (Nogueira Neto, 1991).

Fora realizada uma tentativa de compra de uma área bastante extensa de Garão Maia, lindeira a estação, mas não se concretizou essa iniciativa. Encontrase a citação de Paulo Rezende, pelo empenho na tentativa de aquisição dessa área (Nogueira Neto, 1991).

A Estação Ecológica de Taiamã é constituída por $90 \%$ de zona alagadiça, pontilhada de inúmeras lagoas, no meio de um grande banhado, coberto por capim alto, verificando-se uma grande concentração de cervo do pantanal (Blastocerus dichotomus) (Nogueira Neto, 1991). 
A ocupação da llha não foi fácil, pois localiza-se a $50 \mathrm{~km}$ rio abaixo, em relação a Cáceres, cidade às margens do Rio Paraguai. Inicialmente como não dispunham de uma base logística, utilizou-se a hospedagem e apoio da Fazenda Barranquinho, alugada a uma empresa turística. Foi utilizado o campo de pouso da Fazenda Descalvado. Mais tarde fora alugada uma casa e adquirido um barco a motor. Respondia nessa época como administrador local, Sr. Marcos Ogenibene (Nogueira Neto, 1991).

Para a construção de uma base na ilha, realizou-se um contrato com a Portobrás, a qual operava uma draga nas proximidades de Taimã, tendo construído um aterro de areia, abundante no fundo do Rio Paraguai, destinado às construções das casas e um campo de pouso com $1.000 \mathrm{~m}$ de extensão (medida esta, segundo o autor, para permitir pouso seguro, de aviões bimotores). As obras de aterro foram muito importantes, pois o interior da itha de Taiamã, era muito alagadiço (Nogueira Neto, 1991).

Mais tarde foi incorporada à Estação, uma área vizinha, a liha de Sararé, ao sul, aumentando para 16.000 ha a área total da Estação, o que não é muito, em se tratando de Pantanal. Participou nessa incorporação, o Sr. Odair Zanata, diretor do D.R.F Departamento de Recursos Fundiários do INCRA. A llha de Sararé foi incorporada à Estação de acordo com o processo 0768-009900/78 do SPU após sua arrecadação, segundo a Portaria 321 de 04/10/1983 do Departamento de Recursos Fundiários do INCRA (Nogueira Neto, 1991).

Devido à abundância de jacarés Caiman sp existentes na Estação, esta foi atacada por coureiros, colocando em risco a vida dos guardas, sendo necessária a proteção da Polícia Federal (Nogueira Neto, 1991).

\section{Origem do Nome da Unidade}

Taiamã é uma modificação da palavra "talha-mar" usada para a espécie Rynchops nigra, ave que pesca "cortando"a superfície da água com seu bico forte em pleno vôo (Nogueira Neto, 1991). (Vide figura 41). 


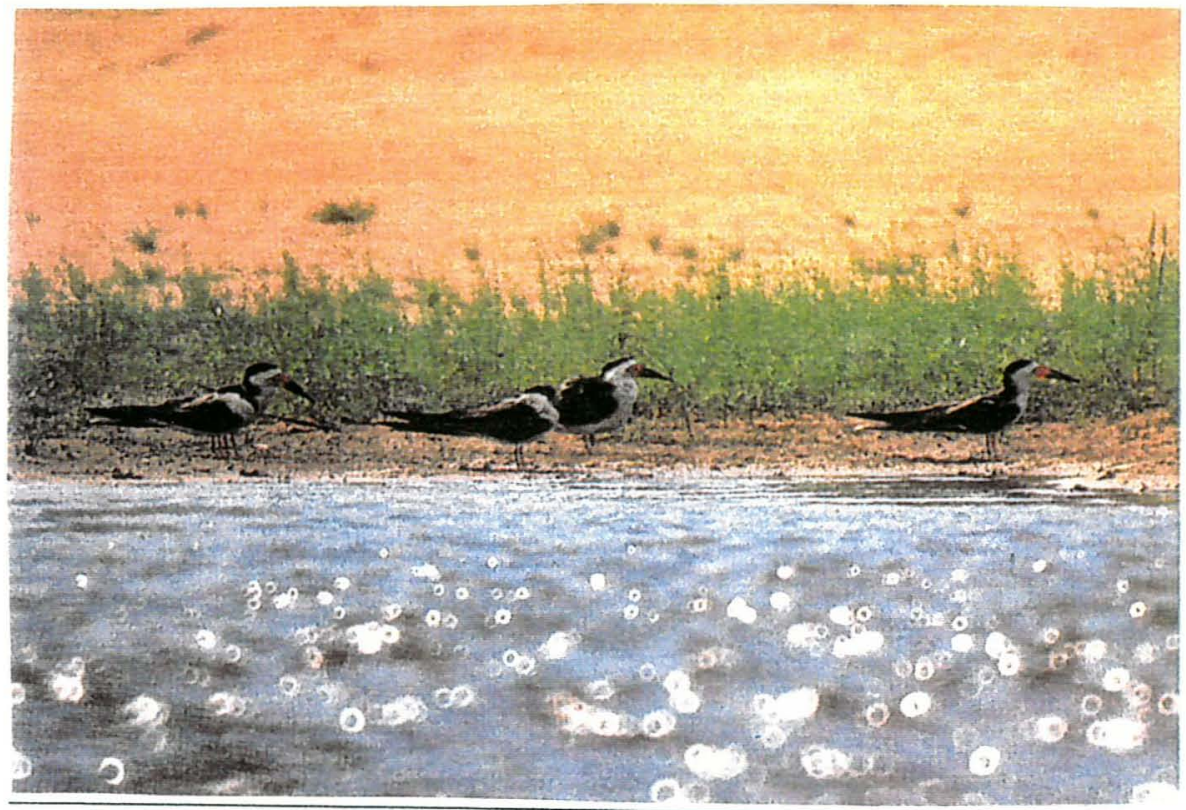

Figura 41 - Ave "Talha Mar" origem do nome da Estação Ecológica.

\section{IV.2. Características Biofísicas da Região}

\section{IV.2.1.Clima}

O Pantanal, segundo Köppen, se enquadra na categoria AW, ou clima de savanas, uma vez que os registros da temperatura média no mês mais frio é superior a $18^{\circ} \mathrm{C}$, e mais de $70 \%$ das precipitações são concentradas no semestre do verão. A média das mínimas desce a $15^{\circ} \mathrm{C}$ em julho, enquanto a das máximas alcançam $34,3^{\circ} \mathrm{C}$ em setembro. Essa particularidade de ter o mês mais quente no final da estiagem conota a massa equatorial um caráter de monção, motivo pelo qual Köppen, denominou-o "Tipo Gangético", a tal variedade de clima tropical. Nimer (1977), classificou o clima da região como quente semi-úmido tropical, podendo ser o inverno frio, devido à penetração de massas polares pela calha do Rio Paraguai (Brasil, 1984). 
A Estação Ecológica de Taiamã encontra-se na parte interna da planície de inundação da bacia pantaneira de sedimentação quaternária. Como área fonte de sedimentação da iha, devem ter participado as rochas dobradas do Grupo Alto Paraguai que ocorrem ao norte da ilha (Brasil, 1984).

\section{IV.2.3 Relevo}

A Estação possui um relevo típico formado por uma seqüência de baixadas e ilhas, estas são pequenas elevações rochosas. Estas ilhas florestadas são circundadas por imensas planuras graminosas, cortadas por rios com floresta aluvial. Essa região divide-se em: baixadas, terraços e ilhas, sendo que Taiamã corresponde à região denominada de baixada. A baixada pode corresponder a outras fisionomias vegetais que são: ambiente pantanoso, ambiente de água estagnada ou corrente temporária, ambiente temporariamente alagado ou apenas úmido (Brasil, 1984).

\section{IV.2.4 Solos}

Os solos da microrregião em que se localiza a Estação, não são muito férteis, predominando solos areno-argilosos, com algumas manchas de latossolos roxos (Brasil, 1984).

\section{IV.2.5. Hidrografia}

A fraquissima inclinação do Pantanal ( 3 a $4 \mathrm{~cm} / \mathrm{km}$;no sentido Norte-Sul e $25 \mathrm{~cm} / \mathrm{km}$ na direção Leste-Oeste, resulta num escoamento mais rápido no sentido Oeste-Leste, provocando um barramento no escoamento das águas do Paraguai e como conseqüência o alagamento da área (Carvalho, 1986).

Os fatores de ordem natural que causam as enchentes periódicas anuais e/ou excepcionais com certa ciclicidade, são as chuvas periódicas anuais regulares que caem na bacia do Rio Paraguai, principalmente nos seus afluentes superiores, a uniformidade topográfica, os fracos desniveis do relevo e a 
predominância de litologias sedimentares recentes (Alvarenga et al., citado por Silva \& Silva, 1995).

Em Mato Grosso, as cheias no Rio Paraguai, na região de Cáceres, ocorrem durante o período mais chuvoso, ou seja, de janeiro a março, e atingem a cidade de Corumbá (MS), em abril, maio e junho, após cessar as chuvas, devido à lenta drenagem do Pantanal.

Além da variação anual do nivel da água, o Rio Paraguai, apresenta uma variação plurianual, que caracteriza períodos de anos, nos quais os níveis máximos e mínimos ficam mais elevados. Grandes extensões de áreas alagáveis do Pantanal, tornam-se alagadas, por cerca de 10 a 15 anos, enquanto dura o ciclo plurianual de águas altas. Estas áreas, voltam a secar no próximo ciclo plurianual de seca (Silva \& Silva, 1995).

Devido ao regime de inundações periódicas ocorre a formação de corpos d'água denominados "corixos e baias". Os corixos são cursos d'água perenes que ligam uma baia a outra. $\mathrm{Na}$ época da cheia espécies da fauna costumam abrigarse em faixas de terreno, que separam uma baia da outra, denominadas "cordilheiras" (Guarim, 1983).

\section{IV.2.6. Vegetação}

A llha de Taiamã situa-se na continuação natural da grande região florística do Chaco Paraguaio e Boliviano. A Estação Ecológica, apresenta extensos campos de gramíneas intercaladas com elementos florestais, com porte elevado e esguio, formando pequenos maciços distribuídos nas ilhas, acrescido da mata ciliar desenvolvida junto aos Rios Bracinho e Paraguai, circundando as lihas de Taiamã e Sararé, sendo chamada de Floresta Aluvial dentro da sub-região florísitica chaquenha (Brasil, 1984).

Às margens das ithas existe uma vegetação rasteira e logo após ocorrem vastas associações de plantas aquáticas margeando-as. Nesta área surgem colônias de Aguapé (Eichornia crassips) que servem de abrigo a inúmeros peixes que nela depositam seus ovos. (Vide figura 42). 


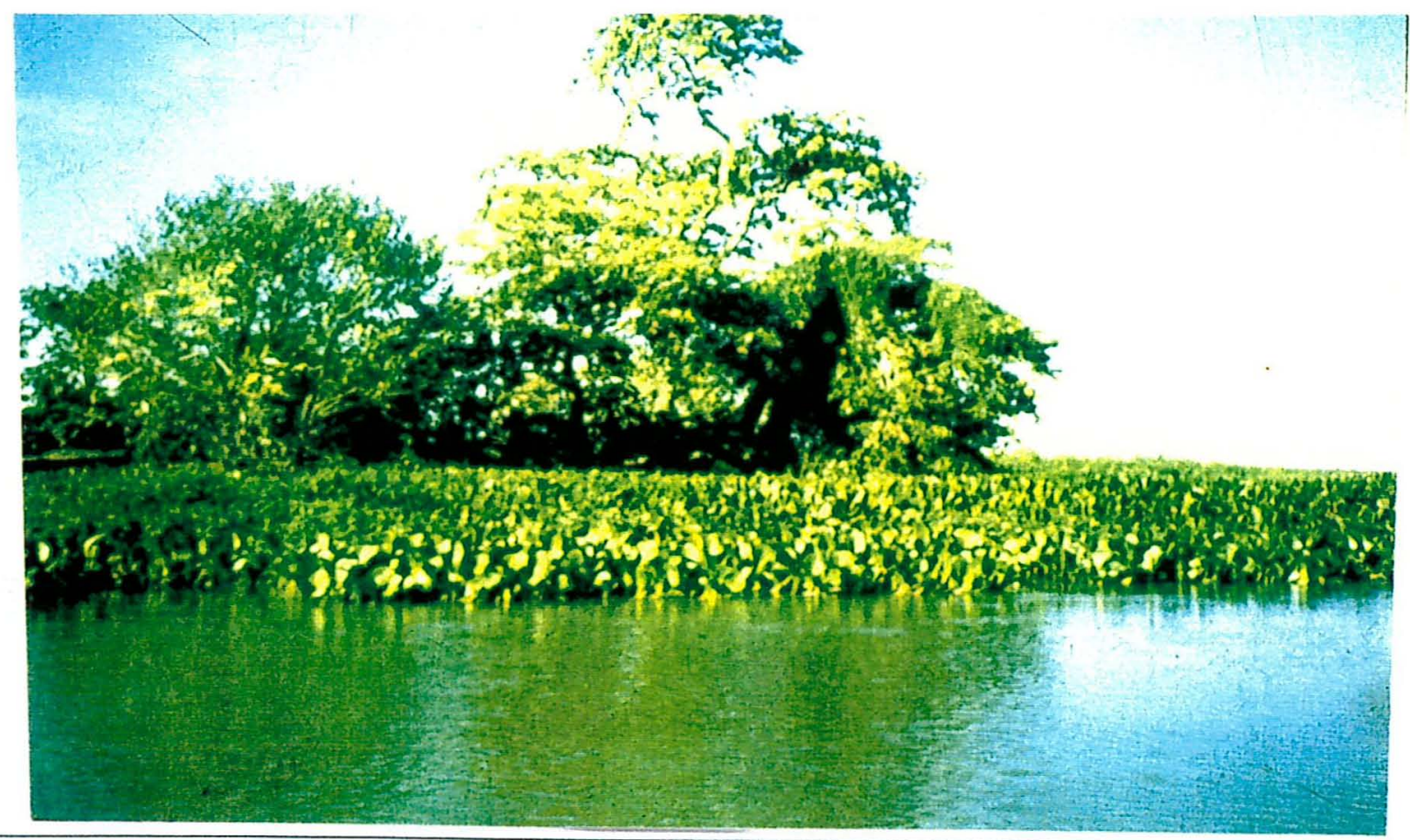

Figura 42 - Plantas aquáticas que margeiam as ilhas de Taiamã e Sararé.

$\mathrm{Na}$ época das cheias, verdadeiras ilhas de aguapé descem flutuando o Rio Paraguai, servindo como meio de transporte da flora e da fauna, de uma região para outra. Encontram-se ainda colônias de Hydromysteria stolonifera, de longos pecíolos que se tornam mais longos quanto mais velhos. Junto à Eichornia crassipes, desenvolve-se Eichornia azurea, a qual ocupa maior extensão que a primeira e também é chamada de aguapé (Silva, 1983).

No Rio Paraguai, as ilhas flutuantes, chamadas pelos pantaneiros de "camalotes", são constituídas de várias plantas aquáticas que são mantidas juntas pelos rizomas de gramíneas e caules de Eichornia, formando esteiras que abrigam plantas menores (Silva, 1983).

As higrófitas herbáceas Zexmenia apensis, conhecidas como fumeiro e o piri ou pripiri Cyperus giganteus, também formam associação (inflorêscencia tipo umbela utilizada como suporte para ninhos de pássaros), destacando-se a primeira, que ocupa extensões consideráveis no Rio Paraguai, assim que este se bifurca, nos Rios Taiamã e Bracinho, apresentando uma paisagem inconfundível na ilha (Silva, 1983). 
Nas fazendas próximas à Estação, terras de pastagem estão se transformando em áreas permanentemente inundadas, em função do assoreamento do Rio Paraguai. A principal espécie que se desenvolve nestas áreas é o fumeiro Zexmenia apensis que modifica completamente a fisionomia de campos para brejos (Silva, 1983).

$\mathrm{Na}$ llha de Taiamã as condições de umidade têm sido favorecidas desde 1974, quando as cheias foram mais altas e a ilha não voltou a secar como na década de 60 , onde na estação seca até queimadas foram realizadas para 0 desenvolvimento de pastagens. Esta situação de "umidade permanente", beneficiou 0 desenvolvimento do "batume".

Nas baias e corixos com batume a água é escura, em função da decomposição da matéria orgânica e o cheiro de gás sulfídrico é fortemente acentuado. As concentrações de oxigênio são baixas neste período, resultando em condições desfavoráveis para os peixes, asfixando-os. No pantanal, o fenômeno da "diquada" ou "dequada", ocorre nos meses de cheia, ocasionando a mortandade de peixes, como os bagres e pintados Pseudoplatystoma corruscans (Pimelodidae) e traíras (Haloplias malaboricus). Quando do início das cheias, as águas das baías com batumes saem para os rios, matando os peixes (Silva, 1983).

Os cascudos, Hypostomus sp e os camboatás, Callychtus s.p., são dificeis de morrer, pois são peixes que vivem em baias com batume.

Em Taiamã, a "diquada" costuma ocorrer no Rio Formoso, de águas escuras, que nasce em áreas onde existe muito batume, desaguando no Rio Bracinho (Silva, 1983).

\footnotetext{
${ }^{4}$ Matéria orgânica proveniente da decomposição de plantas aquáticas flutuantes, que se acumulam nas raizes e estolões das mesmas, iniciando a formação de uma camada flutuante que aumenta á medida que ocorrem mais decomposições, favorecendo a implantação de plantas pantanosas que se fixam no substrato formado. Com a contínua acumulação de matéria orgânica, ocorre um engrossamento dessa camada, elevando-se à $20 \mathrm{~cm}$ acima da superfície da água, podendo ter espessura de até 15 metros, servindo de substrato para árvores e arbustos. As plantas que iniciam o processo de formação do "batume", são Pistia stratiotes, Limnobium stoloniferum, Salvinia auriculata, Ceratopteris pteridoides e Eichornia crassips, seguido-se depois pela implantação da Paspalum repens, Cyperaceae, Polygonaceae e numa fase mais espessa da camada flutuante, aparecem sub-arbustos membros de Leguminosae, Onagraceae e posteriormente árvores como Cecropia sp (Silva, 1983).
} 
A baía do Novato, cercada de batume, mantém mesmo na cheia a cor escura, podendo ocorrer a diquada. Em função da morte do batume, existe uma variação no seu tamanho (Silva, 1983).

Em Taiamã, ainda nas áreas alagadas, pode-se encontrar a Pistia stratiotis (erva-de-santa luzia), as ninféias (Nymphaeas spp), bem como o Cyperus s.p. e Gladium s.p. que misturam-se Echimodorus spp, Sagitaria s.p. e Pontederia lanceolata. Estas plantas são importantes nas cadeias alimentares, como habitat para algas perifíticas, desenvolvendo-se nas suas raízes, riquíssima fauna de invertebrados aquáticos (Silva, 1983).

$\mathrm{Em}$ áreas menos encharcadas, ocorrem espécies pertencentes ao gênero Meliconia, Canna e Maranta (Silva, 1983).

Adentrando a ilha, em locais de solo mais firme, associações de Zexmenia apensis com Hibiscus s.p., ocorrendo também, Polygonum s.p., cuja altura não ultrapassa 2,5 metros. $O$ estrato arbóreo é encontrado em alguns pontos dentro da Estação com a presença de espécies de Leguminosae, Moraceae, Meliaceae, Elaeocarpaceae, Capparidaceae, Anacardiaceae entre outras, atingindo geralmente a altura de 12 a 18 metros ( Guarim Neto, 1983).

Existe também um estrato subarbustivo-arbustivo, com representantes das famílias Compositae, Apocynaceae, Malpighiaceae, Nyctaginaceae, Sterculinaceae, Melastomataceae, Guttiferae e outras, não ultrapassando 2,5 a 3,0 metros ( Guarim Neto, 1983).

O estrato herbáceo é pouco encontrado nas áreas mais afastadas das águas, com representantes das familias Verbenaceae e Leguminosae. Na área alagável, em porções descontínuas, o tronco de árvores, muitas vezes mortos, são cobertos por trepadeiras e cipós das familias Vitaceae, Passifloraceae, Asclepediaceae, Convolvulaceae, Apocynaceae, Combretaceae e outras (Guarim Neto, 1983).

Dentre as palmeiras que existentes na Estação Ecológica estão: o Acuri (Attalea princeps), que é encontrado nas margens mais elevadas dos rios e dos freqüentes corixos; Tucum, também designado Tucumã, que corresponde a diversas espécies do gênero Bactris e Astrocaryum ( Guarim Neto, 1983). 
Um dos elementos arbóreos mais significativos na estação Ecológica é - Abobreiro (Erytrina s.p.), formando associações que se condensam em "ilhas", chamadas abobreiras, facilmente reconhecidas devido à beleza de sua inflorescência. Outras espécies observadas são: Louro Preto (Nectandra mollis); Tarumã (Vitex s.p.); Jatobá (Hymaenea s.p.); Ingá (Inga s.p.); Aroeira (Astronium s.p.); Guatambú (Aspidosperma olivacea); Angico vermelho (Piptadenia s.p.); Angelim (Andira s.p.); Paratudo, Ipê (Tabebuia); Cambará (Vochysia divergens) e Figueira (Ficus) (Guarim Neto, 1983).

Nas margens da Estação ocorre o fumeiro (Zexmenia apensis) característico dessa região, onde formam extensas associações, impossibilitando muitas vezes a penetração (Brasil, 1984).

\section{IV.2.7. Fauna}

A grande riqueza ictiológica do Rio Paraguai dificilmente pode ser comparada, pois o pantanal se constitui num dos mais importantes centros de reprodução existentes. Como se sabe, os peixes não se reproduzem nos leitos dos rios, mas nos lagos e baías no interior do Pantanal, no período das inundações constantes.

Dentre as principais espécies, podemos citar: o dourado (Salminus maxillosus); Pacú (nome de vários gêneros Myleus, Metynnis, Mylossoma e Pyaractus); Piranha (Serrasalmus e Pygocentrus); Pintado (Pseudoplatystoma corruscans) e o Jaú (Paulicea luetkent). Além dessas, pode-se citar muitas outras.

Os principais répteis encontrados na Estação são: o jacaré (Caiman sp.), uma das espécies mais afetadas pela caça predatória, sendo levado quase ao extermínio em Taiamã. No momento encontram-se em processo de recuperação juntamente com o jabuti (Testudo tabulata), o cágado (Platemys s.p.) e a Sucuri (Eunectes murinus) (Brasil, 1984).

O jaboti é habitante das matas, onde se alimenta de vegetais e frutos caídos, sendo a sua carne apreciada na região. $O$ cágado é uma espécie bastante distribuída nos rios e regiōes alagadas. A sucuri, vive de preferência nas matas que 
margeiam grandes rios, encontrando na ilha de Taiamã, excelentes condições para sua sobrevivência. Existem ainda outras espécies, inclusive venenosas, como a Cascavel (Crotalus terrificus), Jararaca (Bothrops jararaca) e Jararacuçú (Bothrops jararacuçu) (Brasil, 1984).

Os mamiferos mais significativos da área são a Anta (Tapirus terretris), a Capivara (Hydrochoerus hydrochoeris), a Paca (Cuniculus paca), a ariranha (Pteronura brasiliensis) e o Macaco prego (Cebus apella).

A avifauna mais representativa da Estação Ecológica está constituída de aves aquáticas, especiaimente grande número de aves migratórias, que no período da vazante, se alimentam dos peixes aprisionados na baias e lagoas rasas; que se reúnem em grandes grupos, constituindo-se nos "viveiros". As aves mais representativas da itha, são: Garça-branca-grande (Casmerodius albus); Baguari ou Garça Cinza Grande (Ardea cocol); Garça-branca Pequena (Egretta thula); Socozinho (Butorides striatus), Garça Real (Pilherodius pileatus); Socó-Boi (Tigrisoma lineatum); Arapapá (Cochearius cochlearius); Tuiuiu (Jabiru mycteria); Cabeça Seca (Mycteria americana); Curicaca cinza (Harpiprion caerulescens); Curicaca (Theristicus caudatus); Colhereiro (Ajaia ajaja); Tachan (Chauna torquata). Dentre os anatídeos, as principais espécies observadas estão o Marrequinho (Dendrocygna bicolor); Marreca-cabocla ou Marreco (Dendrocygna autunnalis); Irerê (Dendrocygna viduata) e o Pato do mato (Cairina moschata) (Brasil, 1984).

\section{IV.3. Ocorrência de fenômenos naturais}

O tema enchentes foi abordado em conjunto com o tópico Hidrografia (ver ítem 4.V.2.4).

\section{IV.4. Características sócio-econômicas e culturais}

\section{IV.4.1. Situaçāo Fundiária}

A Estação Ecológica de Taiamã, foi criada através do Decreto $n^{\circ} 86061$ de 02 de junho de 1981, composta de uma lha de aproximadamente 11.000 ha. 
Posteriormente foi acrescentada uma nova llha, com cerca de 5.000 ha, pela Portaria $n^{\circ} 321$ de 04 de outubro de 1983 do Programa Nacional de Política Fundiária do INCRA. A área encontra-se regularizada, porém não demarcada.

\section{IV.4.2. Uso da Estação}

A Estação não possui Plano de Manejo, portanto não podendo desempenhar as funções estabelecidas pela Lei que a criou, enquanto os usos legais permanecem inviabilizados, prevalecendo alguns usos indevidos:

(i) Pesca : a pesca que ocorre na Estação e seu entorno é ilegal e sem controle. Pode ser dividida na pesca praticada por pescadores comerciais e amadores que visitam a região, uma vez que essa atividade é oferecida aos turistas, como lazer, pelas empresas de turismo, sem muitas explicaçōes sobre a existência da Unidade de Conservação e seus limites.

Ressalta-se que a modalidade mais danosa à Unidade de Conservação é a pesca praticada por pescadores profissionais, capturando grandes quantidades de pescado para revenda para grandes frigoríficos do sudeste; e também a pesca indiscriminada praticada por alguns amadores, que visam a revenda. As embarcações usadas, partem do porto de Cáceres, ganhando acesso a pontos de pesca no interior da Estação e seu entorno. Mesmo possuindo uma placa informativa antes da chegada aos limites da Estação, muitos alegam desconhecê-la. O ponto de penetração das embarcações se faz pela bifurcação do Rio Paraguai com o Rio Bracinho, local conhecido por Castelo de Areia, existindo nesse ponto um Posto de Fiscalização abandonado.

(ii) Caça ilegal de Jacaré: o problema foi muito mais sério na década anterior, quando os coureiros fortemente armados, invadiam a Estação e seu entorno para a concretização de seus intentos, a caça aos jacarés. Atualmente, com a queda do preço do couro, há uma diminuição considerável da matança indiscriminada desses répteis. 


\section{IV.4.3. Histórico da ocupação do pantanal e região}

A ocupação humana em Mato Grosso está datada em 8.000 anos, segundo dados de arqueológicos, da região da Serra de São Gerônimo, Rondonópolis (Silva \& Silva, 1995).

Após a descoberta do ouro em Mato Grosso, antiga provincia de São Paulo, passou a viver longos períodos de guerras. As sociedades indígenas existentes entre os Rios Paraguai, São Lourenço e Cuiabá, principalmente Bororo, Paiaguá, Guató, Guaykuru, e Kaiapó que faziam incursões nesse território, passaram a ser perseguidos e guerreados, como se fossem intrusos em seu próprio território, tornando-se pior a situação, quanto maior a proximidade com as minas (Silva \& Silva, 1995).

Além das guerras com as sociedades indígenas, que eram um obstáculo à ocupação portuguesa, também estiveram no mesmo período, envolvidos em combates com os espanhóis. Na verdade, o mais importante na região era a consolidação e ampliação das fronteiras nacionais, disputadas com a América Espanhola (Silva \& Silva, 1995).

As primeiras notícias sobre sociedades indigenas que habitavam os Pantanais do Mato Grosso, são dadas por Alvar Nunes Cabeza de Vaca, no ano de 1542, quando governador do Rio da Prata. Seu objetivo era utilizar as sociedades indigenas da região como aliados dos espanhóis, na guerra por limites de território, bem como no processo de colonização.

Os Guaykuru, durante muito tempo, serviram de barreira à fixação, tanto de espanhóis como de portugueses, em vasta porção de terras dos Pantanais Mato-grossenses. Durante todo o século XVII, os espanhóis travaram guerra contra os Guaykuru e Paiaguá. Em 1791, um tratado de Paz, deciara os Guaykuru súditos da Coroa Portuguesa (Siqueira, 1990).

Registros afirmam que em meados do século XIX, os Paiaguá, viviam no Chaco Paraguaio, e segundo Moutinho citado por Silva \& Silva, 1995, atribui-se sua extinção no Brasil á guerra que travaram contra os Guaykuru, nos fins do século XVIII. De sua cultura, não existe nenhum registro etnográfico 
As menções aos Guató, no século XVIII, são raras, aparecendo já em 1725, como "índios domésticos", fazendo-se supor que não se confrontaram com as frentes colonizadoras de Mato Grosso. Foram descritos como antigos habitantes das margens dos Rios São Lourenço e Paraguai. Em meados do século XIX, calculava-se quase 500 indivíduos, em situação de quase mendicância. Hoje são constituídos por apenas algumas famílias que vivem próximas a Corumbá e dois deles vivem na área decretada do Parque Nacional do Pantanal Mato-grossense.

Os Bororo, Paiaguá e os Gaykuru, serviram de barreira à fixação dos brancos nos ermos dos pantanais. Apenas em finais do século XVIII, o Pantanal passa a ser uma possibilidade concreta de núcleos de colonização, uma vez que os principais grupos indígenas que lá viviam foram extintos ou por demais enfraquecidos, em função dessas duas causas: o interesse por riquezas minerais aliada à barreira das sociedades indígenas, o Pantanal não se constituiu em atrativo imediato ao povoamento definitivo (Silva \& Silva, 1995).

Talvez tenha sido o próprio gado (introduzido no Estado em 1737), que tenha "puxado" com suas patas, os homens para o Pantanal; o que explicaria a enorme importância que assume para a população pantaneira (Silva \& Silva, 1995).

As primeiras notícias de produção econômica em moldes industriais no Pantanal, datam de meados do século XIX na Fazenda Descalvados, próximo a Cáceres, onde se produzia extrato e caldo de carne. Existem evidências de que a mão-de-obra utilizada era fundamentalmente indígena, em particular do Bororo (Silva \& Silva, 1995). (Figura 43).

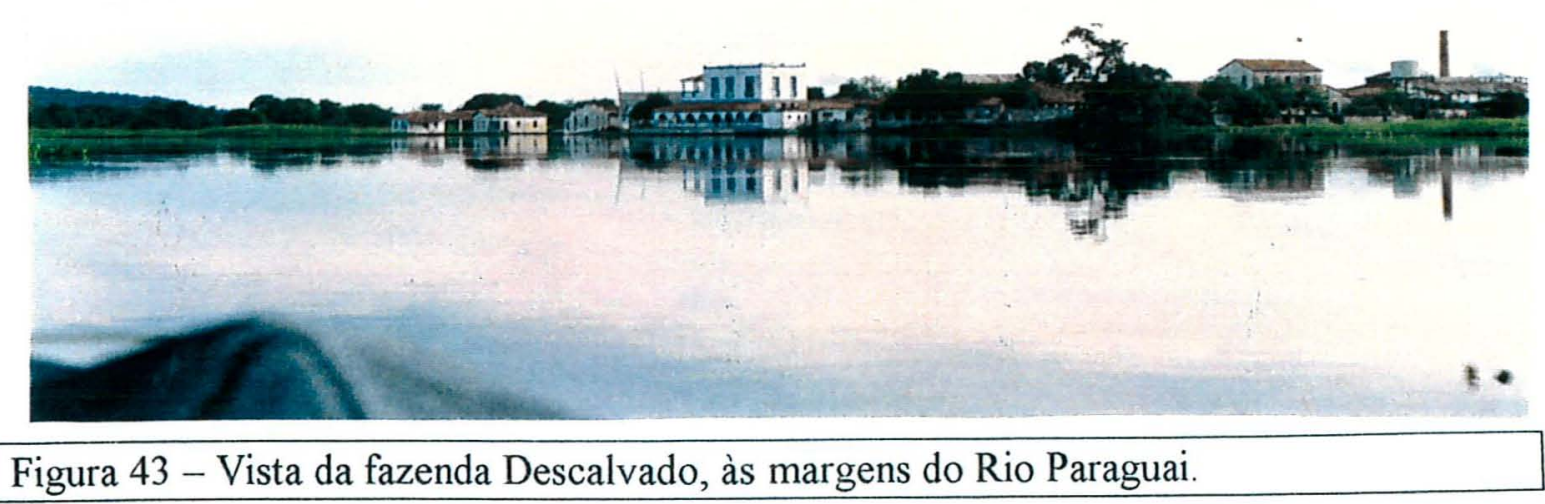


O Pantanal foi preponderantemente ocupado por grandes fazendas de criação extensiva de gado, mas traz em seu bojo, bolsões de uso diferenciado desse espaço. São remanescentes de antigos quilombos, de comunidades camponesas que formaram a partir de sesmarias ${ }^{5}$ doadas em finais do século XVIII e XIX, e em hipótese, de grupos indígenas semi-dispersos, como por exemplo os Guató (Silva \& Silva, 1995).

As doações de sesmarias foram sustadas com a Independência, em 1822, coincidindo com a proibição do tráfico negreiro. Em 1850, com a Lei de Terras, definiu-se que as propriedades poderiam ser adquiridas mediante compra e venda. Com esta Lei, favoreceu-se a institucionalização dos latifúndios (favorecidos fortemente pela doação das sesmarias). Foram regulamentadas as sesmarias devidamente cultivadas, com as taxas e documentação regularizadas. Porém eram processos tão complexos e demorados, que poucos foram beneficiados (Silva \& Silva, 1995).

No final do século $X I X$, intensifica-se a pressão sobre a terra, com a mudança das forças produtivas, e o acesso a ela é dificultado a pequenos proprietários, negros libertos e antigos posseiros. Esse processo reflete-se em Mato Grosso bem mais tarde, já na década de 60 , com a retomada do bandeirantismo e da marcha para o Oeste, que havia se iniciado na década de 40 . Com a política de migração e programas de desenvolvimento regionais, tais como o PIN (Programa de Integração Nacional) na década de 70 e o POLONOROESTE na década de 80 , aumentaram com violência as pressões sobre a terra valorizada.

Apenas recentemente e provavelmente com mais intensidade a partir da década de 80 , algumas sesmarias dividiram-se e foram vendidas a particulares, parcial ou totalmente, hoje empobrecidos, pela diminuição da capacidade de suporte

\footnotetext{
${ }^{5}$ Originárias de Portugal do séc. XII, instituição de concessão de sesmarias a quem se dispusesse trabalhar na terra. Na Idade moderna, adaptada às colônias como forma de garantir a colonização. Em Mato Grosso as primeiras doações foram realizadas a partir de 1727. Havia uma distinção entre as medidas para terras de lavoura (1089 ha) e as destinadas aos "campos de criação" (13.068 ha), mas no Mato grosso as medidas eram extrapoladas, pois esse controle era dificil. A distribuição de terras ficava a cargo de seis delegados municipais , que eram chamados de sesmeiros, e a sexta parte do produto tirado da terra - a sesma- era utlizada para pagar a taxa referente ao uso da terra. A área padrão das semarias portuguesas eram de $6.500 \mathrm{~km}^{2}$ (Silva \& Silva, 1995).
} 
dos solos, e uma crescente dificuldade em sobreviver às novas forças do capital e à política econômica (Silva \& Silva, 1995).

Quando a Fazenda Descalvados foi vendida a proprietários, que utilizavam a criação extensiva de gado que invadiam as terras dos Bororo, as áreas foram demarcadas para os antigos moradores e também para os novos invasores. Mas já naquela época, os brancos desrespeitavam os acordos e invadiam as terras indígenas. Como não houvesse solução pacífica para o caso e os criadores de gado continuavam a invadir as terras dos Bororo, foi chamado Candido Mariano da Silva Rondon, que sabia da existência de um documento assinado, quando da primeira divisão de terras, que garantia a posse da propriedade para os índios Bororo. Porém quando foi procurar o cacique, este havia falecido e a documentação havia sido queimada por sua filha, que não sabia ler, desconhecendo a importância dessa documentação.

Expulsos de suas terras, que habitaram por tantos séculos e obrigados a conviver com formas de exploração econômica, as quais não estavam acostumados, os índios Bororo resolveram abandonar a região e o último reduto da tribo que se tem conhecimento foi a llha de Taiamã.

\section{IV.4.4. Aspectos Culturais}

Os índios Bororo foram contatados em 1901 e várias provas atestam sua passagem pela região. Segundo depoimentos de uma remanescente na fazenda Descalvado, a Sra. Maria Fernandes, conforme contava sua avó, os Bororo faziam urnas mortuárias onde eram colocados os ossos de seus mortos e enterrados. Várias urnas foram desenterradas quando das construçöes na fazenda, atestando com isso o domínio da construção desses sarcófagos. Na Estação Ecológica existem também, pedaços desenterrados desses sarcófagos, guardados dentro do posto de Fiscalização "Aterro dos índios", com as seguinte localização geográfica $16^{\circ} 56^{\prime} 56.9^{\prime \prime}$ $157^{\circ} 22^{\prime} 52.9^{\prime \prime} \mathrm{W}$. Porém encontram-se abandonados por falta de funcionários. 


\section{IV.5. Área de influência da UC}

\section{IV.5.1. Área de entorno}

O entorno de $10 \mathrm{~km}$, não apresenta grandes problemas devido à sua condição de encharcamento permanente, como na área da Estação. Mesmo sendo fazendas de criação de gado, essa região é de difícil acesso, o que leva os seus proprietários a deixá-los em locais mais altos e secos, distantes dali. (Figura 44).

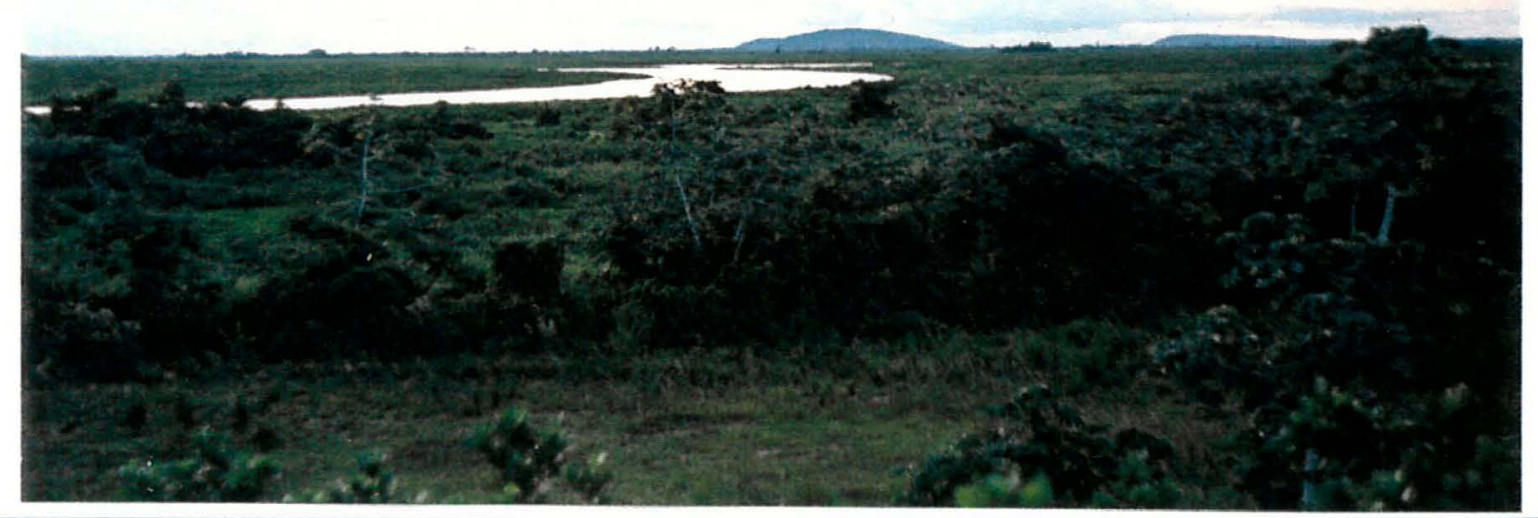

Figura 44 - Aspectos da Estação e seu entorno.

\section{IV.5.2. Cidade de Cáceres}

O Município de Cáceres possui sua principal fonte de renda oriunda do setor primário da economia, e a maior parte de sua população concentrada na área urbana da cidade.

A bovinocultura de corte é predominante no Município, e das 480.000 cabeças; 147.723 são criadas no sistema de exploração extensiva na planície pantaneira, por grandes produtores, e outras 303.727 cabeças na região considerada alta, morraria e áreas consideradas não encharcáveis, no sistema semi-extensivo e intensivo.A bovinocultura de leite é realizada por pequenos e médios produtores, em áreas de terra firme (EMPAER, 1996b). 
O parque industrial de Cáceres ainda é pequeno e insipiente, dentre eles 01 Curtume (670 couros/dia), localizado na ZPE; 01 frigorífico (abatedouro, fábrica de embutidos e corte de carne, 500 cabeças/dia); 01 laticínio (5.000 I/dia) (EMPAER, 1996b).

O Município conta com muitos recursos naturais, como o Rio Paraguai e seus afluentes, praias, pantanal, vegetação diversificada, cavernas, sítios arqueológicos, fazendas históricas, etc. Mas se torna importante frisar, que apesar de todo seu potencial, a principal atração é a pesca. A cidade promove dois Festivais de Pesca, em nível internacional, um em março e outro em outubro.

\section{IV.6. Aspectos Institucionais}

\section{IV.6.1. Infra-estrutura}

A Estação possui infra-estrutura para receber em torno de 20 pesquisadores na sede, que funciona como casa do Chefe da Estação. É composta de laboratório, escritório, refeitório, sanitários e alojamentos, ocupando uma área de $321 \mathrm{~m}^{2}$ de construção. (Figura 45).

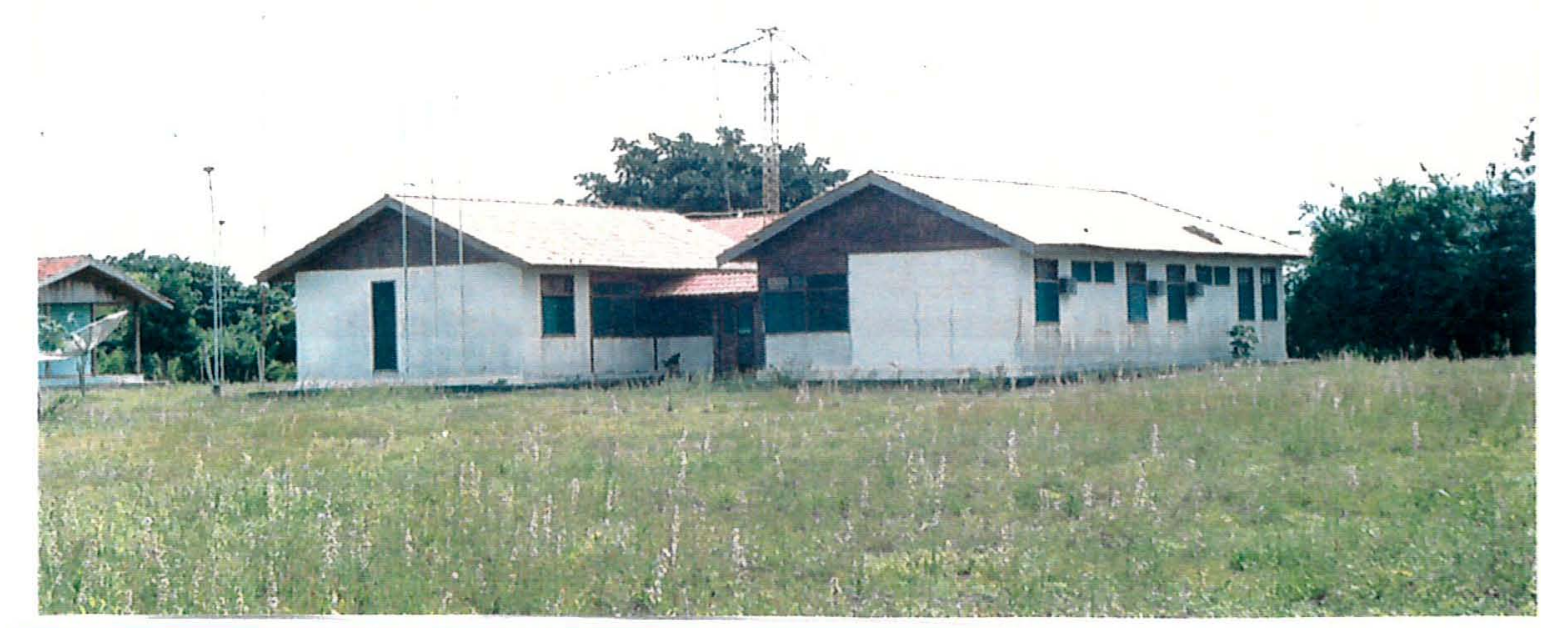

Figura 45 - Aspectos da sede e alojamentos da EE Taiamã.

2) Duas casas de funcionários, em alvenaria e em razoável estado de conservação, com $90 \mathrm{~m}^{2}$ cada uma delas. 


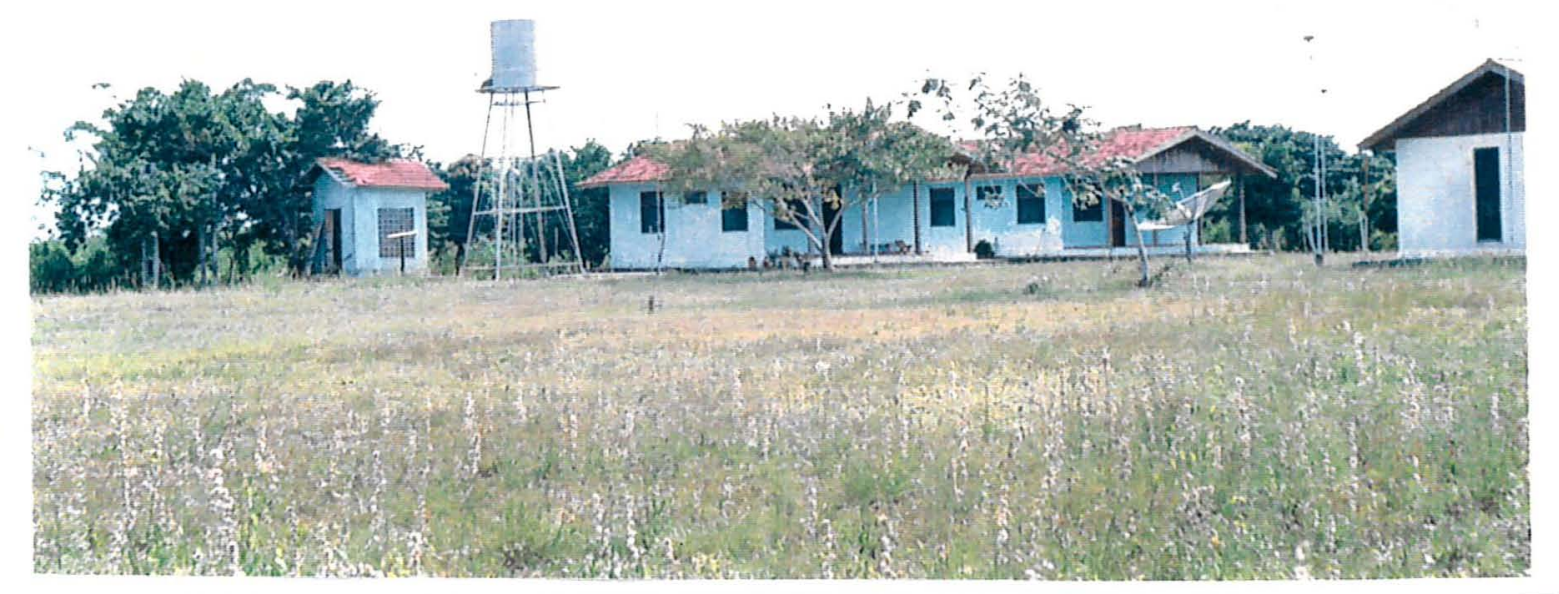

Figura 46 - Vista geral das casas de funcionários da EE Taiamã.

3) Dois postos de fiscalização abandonados e em mau estado de conservação, um deles chamado de "Castelo de Areia" (figura 47), e o outro "Aterro dos Índios". Ambas construções ainda da época da SEMA.

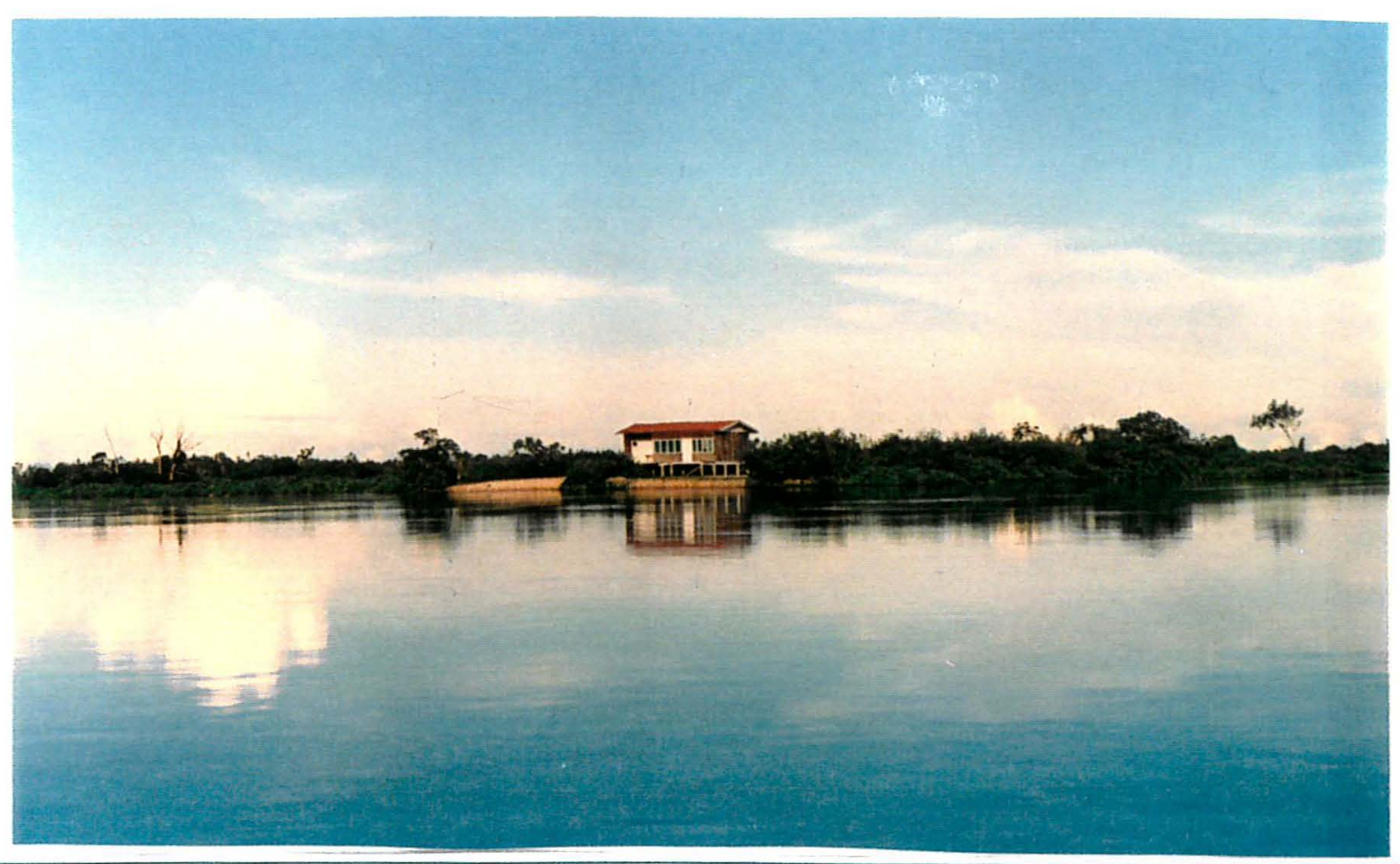

Figura 47 - Aspecto do posto de Castelo de Areia, atualmente abandonado. 


\section{IV.6.2.Pessoal}

Tabela 05 - Quadro de pessoal da ESEC Taiamã

\begin{tabular}{||c|c|c|c|c||}
\hline $\begin{array}{c}\text { Função/Cargo } \\
*\end{array}$ & Portaria /Nomeação & Ano/nascimento & Escolaridade & Cursos/área \\
\hline $\begin{array}{c}\text { 1.Chefe da Estação } \\
\text { 2.Aux.Operac. } \\
\text { Serviços Diversos } \\
* * \\
\text { Chefe Substituto }\end{array}$ & Portaria 1252/96 & 1962 & $\begin{array}{c}\text { Técnico } \\
\text { Agropecuária }\end{array}$ & *** \\
\hline
\end{tabular}

* Não pertence ao quadrodo IBAMA, cargo comissionado.

* Contratado pela ABES, passando para o IBAMA em 01/02/90 e posicionado na Tabela do IBAMA em 1993.

** III Curso de Planejamento e Legislação em Unidade de Conservação. Ilhéus - Bahia. 23/06/1997

à 04/07/1997. Promovido pelo DIREC /IBAMA / PNMA

\section{IV.7 CONSIDERAÇÕES}

A Estação Ecológica de Taiamã, possui 16.000 hectares para praticamente um só funcionário fiscalizá-la por via fluvial, necessitando de pelo menos mais três funcionários, bem como de equipamentos mais adequados para realizá-la.

A área já foi ameaçada pela caça ilegal de jacarés principalmente, mas esse comércio está à mercê de um mercado internacional e assim que o couro tenha preços compensatórios a área voltará a correr sérios perigos, uma vez que o único funcionário não possui equipamentos adequados para uma fiscalização eficiente.

A pesca ilegal é uma constante na região, com pescadores oriundos de Cáceres, principalmente, e que adentram nas baías pelo Posto de Fiscalização abandonado "Castelo de Areia", o ponto crucial da Estação.

Outro fator de preocupação é a Hidrovia Paraguai-Paraná, que propõe as mudanças mais drásticas na região do Rio Paraguai, que circunda praticamente toda Estação Ecológica de Taiamã. 


\section{V.PARQUE NACIONAL DO PANTANAL MATOGROSSENSE}

\section{V.1. Situação histórica e geográfica}

\section{V.1.1. Localização e Limites}

O Parque Nacional do Pantanal Matogrossense está situado no extremo sudoeste do Estado de Mato Grosso, no Município de Poconé, junto à divisa com o Estado de Mato Grosso do Sul, na confluência dos rios Paraguai e Cuiabá.

Os limites do Parque se enquadram entre as latitudes $17^{\circ} 26^{\prime} \mathrm{S}$ e $17^{\circ} 52^{\prime} \mathrm{S}$ as longitudes $57^{\circ} 10^{\prime} \mathrm{W}$ e $57^{\circ} 41^{\prime} \mathrm{W}$. A sua área é de 138.000 hectares e seu perímetro $260 \mathrm{~km}$.

Seus limites são formados pelos Rios Paraguai, São Lourenço (denominação local do trecho do Rio Cuiabá que limita o Parque) (figura 48), Caracará e Caracarazinho, e por vários rios menores, lagos e baías. A nordeste, o Parque limita-se por terra com a Fazenda Doroché. Do outro lado do Rio Paraguai, encontra-se a Serra do Amolar, que atinge 900 metros de altitude, contrastando com o resto da Unidade e seu entorno que consiste de terras baixas e planas, pontilhadas de pequenos morros. (Vide figura 49)

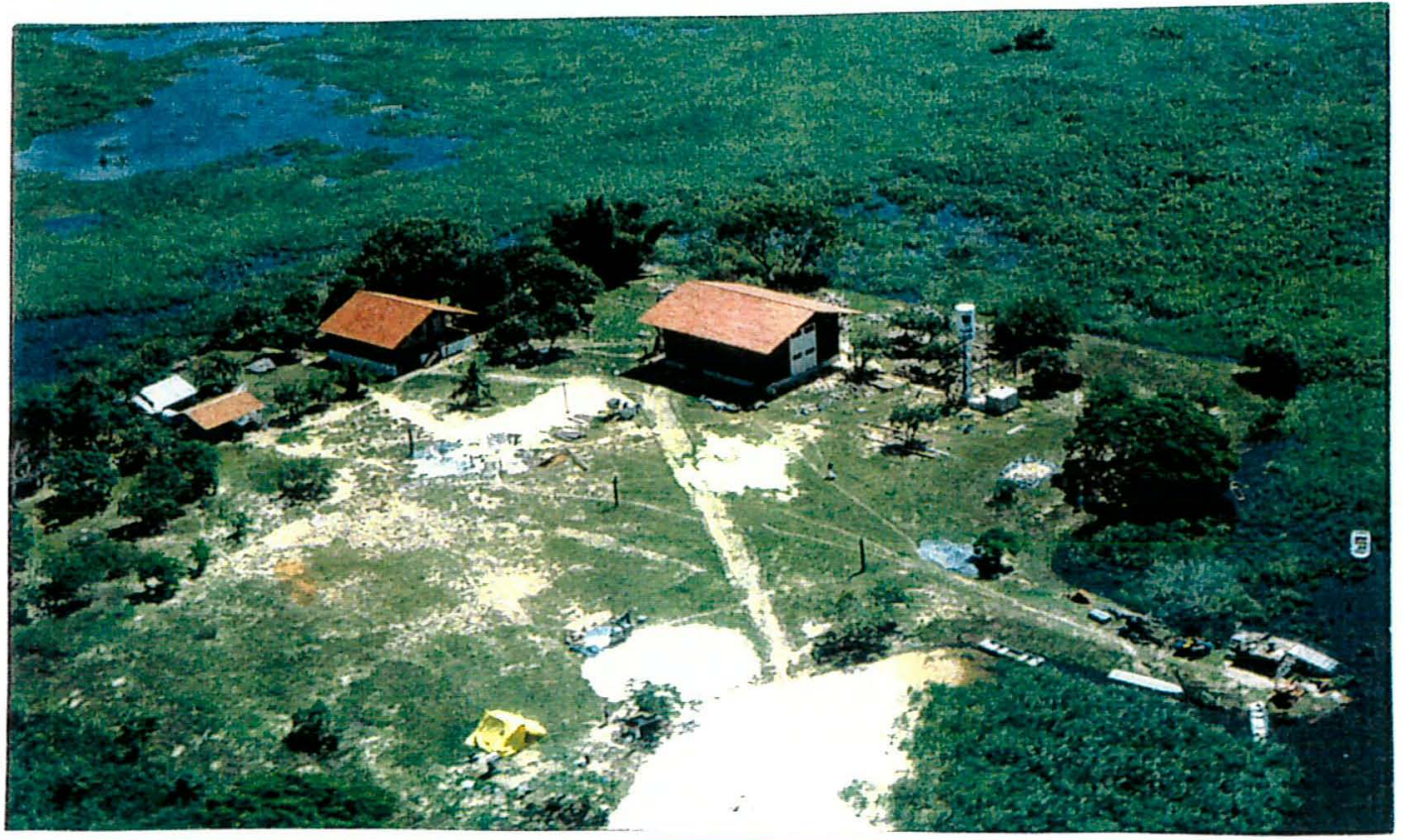

Figura 48 - Vista geral da sede do parque Nacional, à beira do "Rio São Lourenço". 


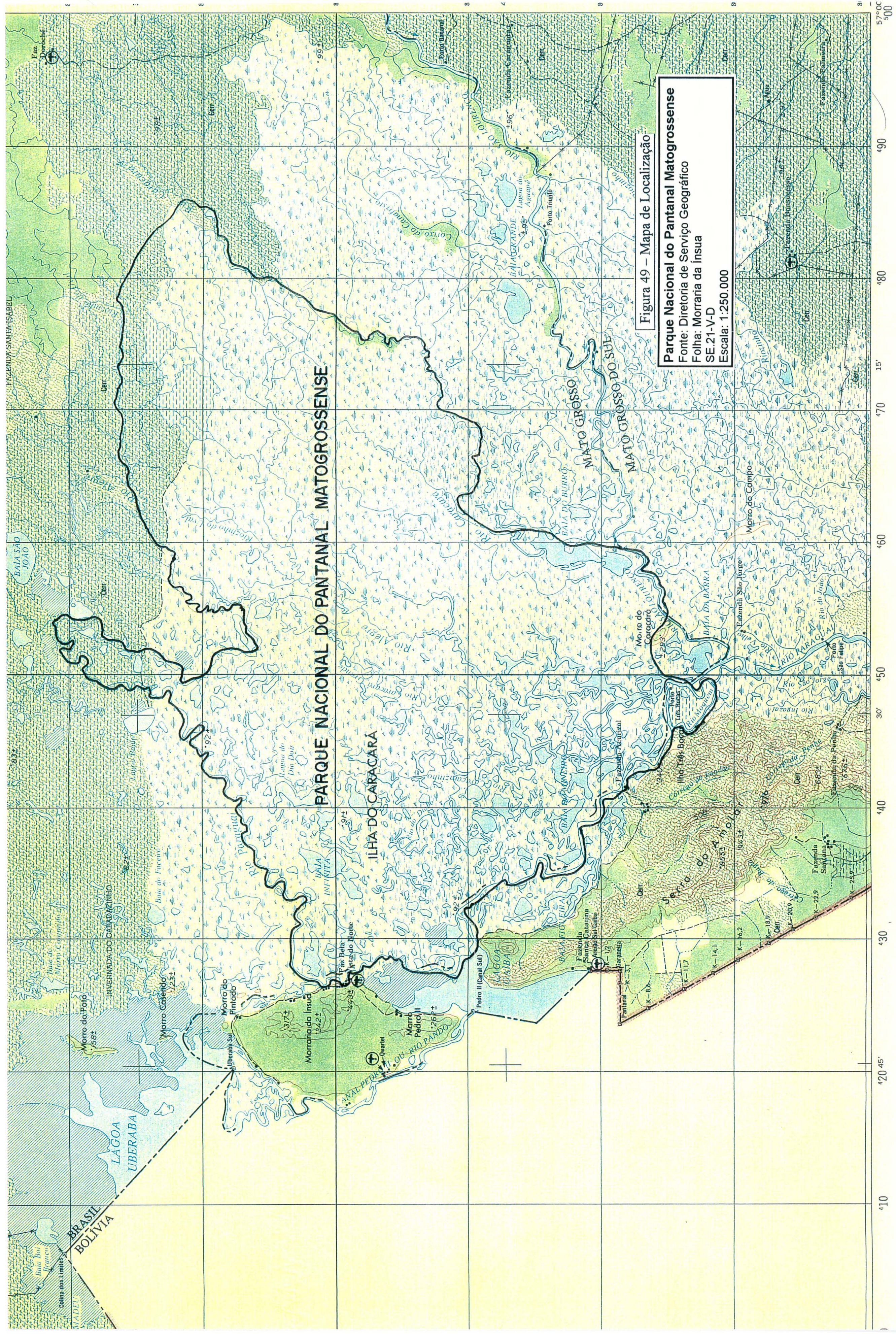




\section{V.1.2. Vias de Acesso}

O Parque Nacional é acessível por via fluvial. Existem duas vias de acesso: uma delas partindo-se de Cuiabá (MT), por rodovia asfaltada num percurso de $109 \mathrm{~km}$ até Poconé, continuando pela Rodovia Transpantaneira, atualmente em condições precárias, segue-se até Porto Jofre, às margens do Rio Cuiabá, de onde o acesso por barco até a sede do Parque dura aproximadamente 3 horas de viagem. $A$ outra via, partindo-se de Campo Grande (MS), pela BR-262 até Corumbá (415 km), de onde, se sobe por barco, até a sede, em aproximadamente 5 horas de percurso. No Parque, o único meio possivel de locomoção é o fluvial. No acesso por via aérea, pode-se utilizar eventualmente, o campo de pouso da fazenda Acurizal, lindeira ao Parque.

\section{V.1.3. Histórico da Unidade de Conservação e Antecedentes Legais}

Em 1971, ocorreu na região, uma grande enchente que veio modificar o regime hidrológico local. E a maior parte das pastagens da Fazenda Caracará, propriedade do empresário João Borges, ficaram submersas permanentemente. As áreas que permaneciam secas após as enchentes foram insuficientes para a continuação de criação de gado, para a qual se utilizavam amplas pastagens nativas em regime de rotação (Brasil, 1994).

Esse evento coincide, com uma crescente preocupação da sociedade, sobre modificações que o ciclo natural de cheias e secas do Pantanal, vinha sofrendo devido a atividades antrópicas, bem como a depredação da fauna e flora regionais. Iniciando-se concomitantemente no âmbito científico um movimento para a criação de uma Unidade de Conservação que protegesse uma amostra do ecossistema pantaneiro. Atendendo a essa demanda o Governo Federal em 1971, adquiriu a Fazenda Caracará, transformando-a em Reserva Biológica através do Decreto $\mathrm{n}^{\circ}$ 68.691 de 28 de maio de 1971. Posteriormente, mediante o decreto-lei $n^{\circ} 86.392$ de 24 de setembro de 1981, foi então, criado o Parque Nacional do Pantanal 
Matogrossense, com 138.000 ha, correspondendo a toda área da Reserva Biológica e antiga Fazenda Caracará (Brasil, 1994).

\section{V.2. Características biofísicas}

\section{V.2.1.Clima}

O Parque Nacional do Pantanal Mato-grossense encontra-se numa região de clima com características tropicais continentais. O regime de chuvas é tropical, com duas estações: a seca, de maio a setembro, e a chuvosa, de outubro a abril, sendo os meses mais chuvosos os meses de dezembro, janeiro e fevereiro. Segundo RADAMBRASIL, a precipitação total anual está situada em tomo dos 1000 $\mathrm{mm}$. As temperaturas médias oscilam entre $23^{\circ}$ e $25^{\circ} \mathrm{C}$, com médias máximas $e$ mínimas absolutas muito altas, ultrapassando em média, $40^{\circ} \mathrm{C}$ as máximas absolutas e $20^{\circ} \mathrm{C}$ as minimas (Brasil, 1994).

Massas de ar frio de origem polar, nos meses de maio, junho e julho, baixam a temperatura da região do Parque consideravelmente, podendo as mínimas absolutas, atingir $0^{\circ} \mathrm{C}$. Nesses meses também é comum a penetração da massa tropical Atlântica, trazendo ventos do leste, com dias ensolarados e secos. No verão a região é invadida pela massa de ar Equatorial Continental, com ventos oeste e noroeste, altas temperatura, chuvas e trovoadas (Brasil, 1994).

O período seco na região dura cinco meses por ano. Enquanto o clima caracteriza-se por um periodo seco considerável (05 meses), com baixa umidade relativa ( 50 a $60 \%$ na seca e menos de $80 \%$ nas chuvas), a região está sujeita a enchentes provocadas pelas águas pluviais vindas dos afluentes do Rio Paraguai, que devido à pouca declividade da planície pantaneira, tem pouca capacidade de drenagem (Brasil, 1994).

\section{V.2.2. Geomorfologia}

Caracterizado como uma enorme superfície de acumulação, o Pantanal possui topografia bastante plana, sujeita a inundações freqüentes, e comandada pela 
rede de drenagem do Rio Paraguai. O termo Pantanal Mato-grossense, é baseado nestas características geomorfológicas, e muitos pesquisadores, concordam que o termo não é adequado, pois a área não apresenta características de "pântano", porém o termo se popularizou, sendo tradicionalmente utilizado (Brasil, 1994).

Foram identificados doze padrões de pantanais, com aspectos estruturais, morfológicos, hidrológicos, pedológicos e de cobertura vegetal típicos, correspondentes aos pantanais do Corixo Grande - Padre Inácio - Paraguai ou pantanal do Descalvado; do Cuiabá - Bento Gomes - Paraguaizinho ou pantanal de Poconé; Itiquira - São Lourenço - Cuiabá ou pantanal do Pirigara; dos Paiaguás; do Taquari; do Negro; do Jacadigo - Nabileque; do Miranda - Aquidauana; do Tarumã Jibóia; do Aquidabã; Branco - Amonguijá e do Apa (Brasil \& Alvarenga, 1988).

O Parque Nacional do Pantanal Matogrossense, está localizado no pantanal dos Paiaguás. (Vide figura 51).

A Serra do Amolar situada na porção setentrional do Planalto e no limite Sudoeste do Parque, apresenta-se com maior relevo, tanto em aspecto contínuo quanto altimétrico (figura 50). A morraria da Ínsua, posicionada no extremo setentrional e limítrofe no extremo Oeste com o Parque, delineia uma estrutura circular com mais de $300 \mathrm{~m}$ de altitude.

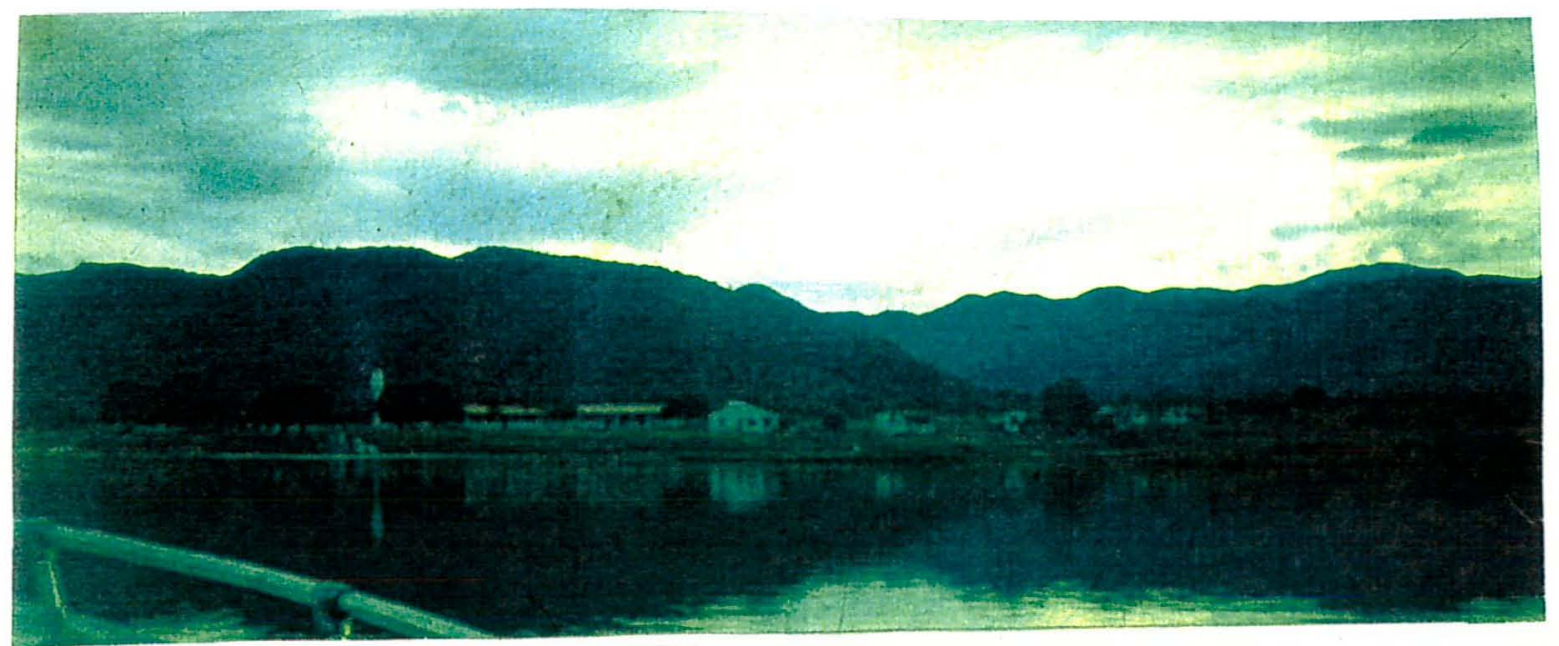

Figura 50 - Vista da Serra do Amolar, ao fundo da Fazenda Acurizal, lindeira ao Parque. 


\section{V.2.3. Solos}

A área do Parque, corresponde aos depósitos aluviais dos rios Paraguai e Cuiabá. A vasta planície flúvio-lacustre destes dois rios comporta aluviöes atuais com areias, siltes e argilas e sedimentos mais antigos, siltico argilosos e argiloarenosos. Os solos são predominantemente do tipo Glei pouco úmido eutrófico, ao longo dos vales fluviais, desenvolvendo-se aí, a Floresta Estacional Decidual Aluvial (Brasil, 1994).

O transporte de sedimento ao longo da bacia é grande e a sua história é a própria formação do Pantanal como uma bacia sedimentar. Há um contínuo transporte de partículas finas em suspensão e, no leito, de areia fina e média. Durante as cheias, as águas de inundação espalham sedimentos no pantanal, bem como grande quantidade de matéria orgânica que contribui para a fertilidade do solo e da água. Grandes quantidades de sedimentos são depositadas nas margens dos Rios Paraguai e Cuiabá formando diques naturais, contribuindo também para o levantamento gradual dos leitos dos rios. Quando isso ocorre, a calha sedimentada fica com menor profundidade e o rio tende a alargar a sua seção transversal, aumentando a área de inundação refletindo nas enchentes (Brasil, 1994).

Na região da Serra do Amolar e na morraria da Ínsua, o solo é litólico eutrófico, recoberto por vegetação de Savana Arbórea Aberta (cerrado) e Floresta Decídua (Brasil, 1994). Vide figura 50.

\section{V.2.4. Hidrografia}

O Parque Nacional está localizado na região hidrográfica denominada Bacia do Alto Paraguai, compreendendo parte da bacia do Rio Paraguai desde suas nascentes até o Rio Apa. Esse rio estabelece os limites entre Brasil e Bolívia (91 km) e o Paraguai (335 km), nasce nas encostas da serra de Tapirapuã (Serra dos Parecis, divisor topográfico de águas com a bacia Amazônica), segue rumo sul até Barra do Bugres e depois Cáceres. Na planície pantaneira corre sinuosamente longos trechos inundáveis até Corumbá. A partir dai segue rumo Sudeste até Porto Esperança e 
Figura 51 - MAPA DA BACIA DO ALTO PARAGUAI E PANTANAIS MATOGROSSENSES

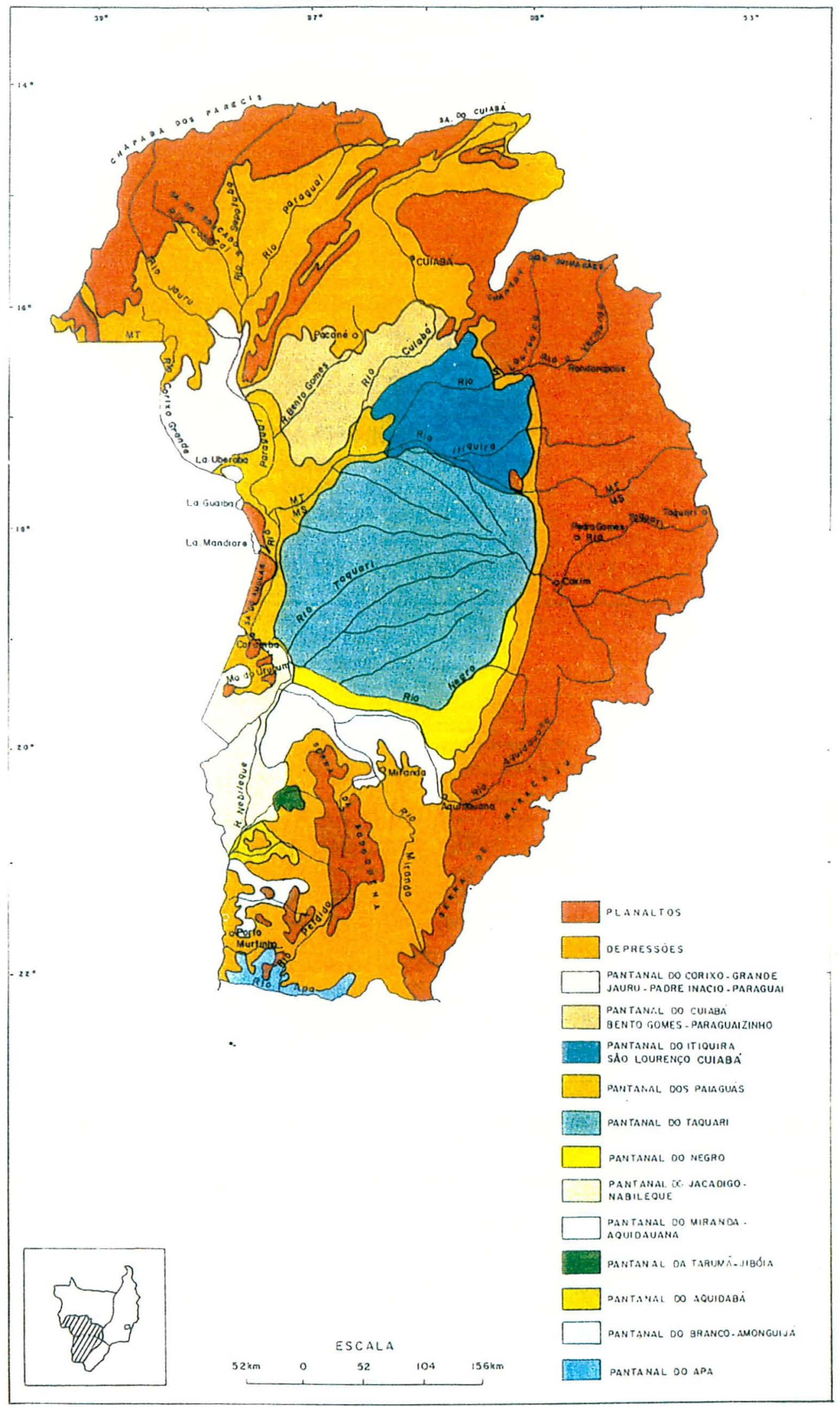


depois rumo Sudoeste, até a foz do Rio Apa, onde entra em território Paraguaio, após um percurso de aproximadamente $1.800 \mathrm{~km}^{2}$ (Alvarenga, 1984). Tem uma área hidrográfica de quase $496.000 \mathrm{~km}^{2}$, dos quais $76,6 \%$ encontra-se em território brasileiro, com cerca de $380.000 \mathrm{~km}^{2}$ nos Estados de Mato Grosso (37\%) e Mato Grosso do Sul (63\%). O rio Paraguai é tributário do Rio Paraná (1095 km²) que, por sua vez, compõe a bacia do Prata $\left(3.100 .000 \mathrm{~km}^{2}\right)$ (Brasil, 1994).

As maiores altitudes da bacia são de quase 1.000 metros, enquanto as menores são inferiores a 100 metros. A parte alta da Bacia possui altitudes superiores a 200 metros. Aproximadamente neste nível, há uma queda brusca, descontínua, que dá formação ao Pantanal, com área de $168.000 \mathrm{~km}^{2}$ no Brasil, correspondendo às terras baixas e região central da bacia, com altitudes inferiores a 80 metros. Por outro lado, a região central onde se localiza o Parque Nacional, inclui algumas áreas acima de $200 \mathrm{~m}$ até $900 \mathrm{~m}$, na zona das Lagoas Gaíva e Uberaba (Brasil, 1994).

A drenagem é realizada por córregos, corixos, vazantes e baías. "Baías"(áreas deprimidas circulares ou semicirculares, com água salobra ou não, atingindo centenas de metros de dimensão, ou antigo meandro); "vazantes" ( são linhas de drenagem entre as cordilheiras, intermitentes ou perenes, servem de escoadouro das baías e rios com vários quilômetros de extensão); "corixos" (pequenos cursos de água conectando baías, com maior poder erosivo que as vazantes, que podem secar por alguns anos); Córregos são pequenos cursos d'água (Brasil \& Alvarenga, 1988).

\section{Rio Paraguai}

Nasce em áreas brejosas de $4 \mathrm{~km}$ de largura a cerca de $240 \mathrm{~km}$ à montante de Cáceres. $\mathrm{A}$ jusante de Cáceres a área de inundação torna-se estreita até Descalvados, quando o rio se bifurca pelo canal principal e pelo chamado "Bracinho" do lado leste. A partir dessa mudança de direção começa a área de pantanal do Paraguai, numa faixa de $25 \mathrm{Km}$ de largura incluindo os dois braços. $\grave{A}$ jusante do Bracinho e somado a rios intermitentes, o rio corre num único leito, com larga faixa de inundação até próximo a Porto Conceição. A cerca de $40 \mathrm{~km}$ à jusante de porto Conceição, o rio corre em três leitos, penetrando na área que hoje compreende o 
PARNA: O Rio Paraguai, mais largo; o Rio Caracarazinho e o Rio Caracará. Os três tornam-se a reunir no Refúgio das Três Bocas, ainda dentro do Parque Nacional e próximo ao seu limite Sudoeste. Essa região é de drenagem complexa, cheia de corixos, vazantes, velhos meandros, pequenos rios afluentes e grandes e pequenos braços do Rio Cuiabá. Com enorme área de inundação. Nos braços mais a oeste, limite do Parque no Rio Paraguai, nas barras dos canais das lagoas Uberaba e Gaiva (Brasil, 1994). Vide figura 49.

A Lagoa Uberaba com uma área de $50 \mathrm{~km}^{2}$ em níveis mínimos, alcança $1.000 \mathrm{~km}^{2}$, em grandes enchentes. Recebe água do Corixo Grande, limite entre Brasil e Bolívia, e de muitos outros corixos laterais e das montanhas ao sul da lagoa, além do Rio Paraguai durante as enchentes. A conexão da lagoa com o Rio Paraguai foi mais ativa no passado, mas aos poucos está se fechando, devido à cobertura vegetal de aguapé (camalote) ou capim-de-praia , que cresce ao fundo (Brasil, 1994).

A Lagoa Gaiva tem uma conformação que a divide em três partes: Gaíva, Pré-Gaíva e Gaíva - Mirim, com uma área total de $75 \mathrm{~km}^{2}$, atingindo $150 \mathrm{~km}^{2}$, na cheia. A Bacia hidrográfica é de $300 \mathrm{~km}^{2}$ propiciada pela rede de drenagem dos morros lindeiros. A saída da lagoa para o Rio Paraguai chama-se Riacho da Gaíva, que faz limite Noroeste do PARNA. Ao norte, a Baía Gaiva se liga com a Baía Uberaba pelo canal (localmente chamado de rio) Pedro II (Brasil, 1994).

A partir do refúgio das Três Bocas o Rio Paraguai corre próximo a Serra do Amolar, localizada a margem oposta a do Parque Nacional, apresentando pequenos braços de $40 \mathrm{~m}$ de largura. Nessa região existem várias lagoas cobertas por vegetação (Brasil, 1994).

\section{Rio Cuiabá}

O Rio Cuiabá tem suas nascentes na Serra Azul e drena uma área de quase $100.000 \mathrm{~km}^{2}$. No seu alto curso, o Cuiabá possui vales íngremes com vegetação densa, recebendo seu afluente pela margem esquerda, o Rio Manso. O vale se alarga próximo a Santo Antônio do Leverger. Ao receber um braço secundário denominado "Rio" Piraim, já próximo a Barão de Melgaço, o Rio Cuiabá adentra em áreas do Pantanal. Da foz do Piraim para jusante, o Cuiabá num único leito varia de $70 \mathrm{~m}$ de largura nas estiagens a $150 \mathrm{~m}$ nas cheias. Parte das águas das cheias 
adentram pelos corixos e rios menores que correm na direção do Rio Paraguai. A partir da ponta norte da llha Camargo Corrêa, o Cuiabá recebe seus principais tributários da planície, os rios São Lourenço e Piquiri. A região passa a apresentar várias vazantes e corixos, bem como lagoas que interligam entre si e com o rio. Próximo à confluência com o Rio Paraguai, o Cuiabá apresenta largas áreas de pantanal pela margem direita, com corixos que escoam na direção do Rio Paraguai. Na margem esquerda encontra-se uma grande área, sujeita a inundação, na qual se localiza o Parque Nacional, sendo a faixa mais larga de inundação do pantanal cuiabano (Brasil, 1994).

Cerca de $5 \mathrm{~km}$ à jusante do Refúgio das Três Bocas, o Rio Paraguai recebe o Cuiabá, seu principal afluente, com uma vazão média de $480 \mathrm{~m}^{3} / \mathrm{segundo}$. Os dois rios possuem direção e fluxos quase contrários: o Paraguai neste trecho tem escoamento para Sudeste, enquanto o Cuiabá quase rumo Oeste (Brasil, 1994).

No século passado, o Piquiri era afluente do São Lourenço que também recebia o Cuiabá, mas sua drenagem foi modificada devido à construção de diques. Dessa forma o Rio Cuiabá passou a ser o mais importante, por apresentar a maior bacia hidrográfica e o maior volume de água. Mas os habitantes locais continuam a chamar o curso inferior do Cuiabá de "São Lourenço", inclusive na região do Parque Nacional.

\section{V.2.5. Vegetaçāo}

Tres categorias de cobertura vegetal ocorrem no Parque Nacional, de acordo com RADAMBRASIL:

\section{V.2.5.1. Savana Gramíneo-Lenhosa sem Floresta de Galeria}

Ocorre nas terras baixas periodicamente inundáveis, apresentando fisionomia de campo, dominado por gramíneas, ocorrendo também plantas lenhosas rasteiras e palmeiras anãs. Muitas vezes, esta formação é intercalada por grupos de árvores e arbustos. Os campos apresentam cor verde durante o período das chuvas e cor pardacenta na estação sêca. Entre as gramíneas, se destacam os gêneros Paspalum, Hermathia, Digitaria, Panicum, Brachiaria, e Axonopus, assim como buritis 
agrupados (Mauritia sp.). Predomina dentro do Parque essa categoria de vegetação, ocupando a maior parte de sua área. Na metade oeste do Parque, a Savana Gramíneo Lenhosa apresenta características de área de tensão ecológica, possuindo enclaves florestais nas áreas mais elevadas (cordilheiras), com espécimes como o jatobá (Hymenaea sp.), ipês amarelo e roxo (Tabebuia sp.), e a palmeira acuri (Atallea sp.) (Brasil, 1994).

\section{V.2.5.2. Floresta Semidecidual Aluvial}

Esta formação destaca-se pela ocorrência de árvores e arbustos baixos, com troncos finos e tortuosos e copas pequenas e espaçadas. Variando de 10 a 15 metros a altura média das copas. Predominando no dossel superior as seguintes espécies: amarelão ( Apuleia molaris), cariperana (Licanea sp.), muiraba (Mourin sp.), imbauba (Cecropia sp.), ingá (Inga sp.), ipê (Tabebuia sp), gameleira (Ficus insipida), e ucuuba (Virola sp.). $\mathrm{Na}$ áreas mais baixas aparecem grupamentos de buritis. A submata é de composição irregular, destacando-se o cipó-imbé (Philodendrum imbe), cipó-de-fogo (Doliocarpus rolandri) e a escada-de-jabuti (Bauhinia sp.). O solo é coberto por uma camada espessa de folhas e galhos. Esta formação ocupa uma área reduzida do Parque, sendo encontrada somente na faixa ao longo do Rio Cuiabá (Brasil, 1994).

\section{V.2.5.3.Floresta Semidecidual das Terras Baixas}

Apresenta composição florística heterogênea, com ecotipos deciduais, ocorrendo no parque em áreas de curto período de inundação. Variando a altura média das árvores em torno de 15 a 18 metros, ocorrendo individuos emergentes. No dossel superior destacam-se o bacupari (Rheedia macrophyla), ingá-cipó (Inga edulis), o louro-preto (Nectandra mollis), a araracanga (Aspidosperma album), a aroeira (Astronium s.p.), joão-mole (Neea oppostifolia), o mututi-duro (Swartia racemosa), pau-d'alho (Gallesia gorazema), peroba-rosa (Aspidosperma s.p.), a muiraba, o caxuá (Trichilia paraensis), o ipê (Tabebuia sp.), o barú (Diptenyx alata). No 
sub-bosque, destacam-se arbustos das famílias Rubiaceae, Myrtaceae e Rosaceae. Próximo a vazante do Rio Cuiabá, ocorrem agrupamentos isolados de cambará (Vochysia divergens), em adensamentos variáveis em forma e tamanho. Esta floresta ocupa parte do extremo noroeste do Parque Nacional, ao longo do Rio Caracará. A maior parte desta formação vegetal estende-se além do limites do Parque, pela fazenda Doroché (Brasil, 1994).

Baseado em pesquisas de campo realizadas em 1992, e análise de imagens de satélite, através de um levantamento Ecológico Rápido (Rapid Ecological Assesment - REA) do Parque Nacional e seu entorno ${ }^{6}$, foi classificada em sete categorias de comunidades naturais:

1. Água (27\%), incluindo rios, baias, e lagos permanentes.

2. Vegetação Flutuante (25\%), composta por substratos flutuantes de materia vegetal, sobre os quais crescem aguapés, gramineas e pequenos arbustos.

3. Campos Inundáveis (36\%) - campos limpos inundados durante parte do ano, as vezes pontilhados por árvores isoladas.

4. Cerrado (1\%) - vegetação arbórea a arbustiva, normalmente não inundável.

5. Florestas Inundáveis (11\%) - matas sujeitas a inundações periódicas ou esporádicas. Algumas áreas com cobertura florestal permanecem inundadas por períodos mais curtos que os campos inundáveis, enquanto outras permanecem secas durante $o$ ano inteiro.

6. Florestas Semi-Decíduas $(0,00005 \%)$ - este tipo de vegetação cresce somente nas encostas, e cobre apenas 7 ha dentro do parque. Porém é abundante na Serra do Amolar, onde cobre 7.000 ha, na área lindeira ao Parque.

\footnotetext{
${ }^{6} \mathrm{O}$ levantamento foi realizado através de um acordo de cooperação entre o IBAMA e a Organização Não-Governamental norte-americana The Nature Conservancy.
} 
7.Vegetação Xerofitica $(0,003 \%)$ - esta comunidade ocupa 373 ha do PARNA, mas cobre 4.600 ha nas encostas da Serra do Amolar e outros 3.000 ha no entorno da Unidade.

\section{V.2.6. Fauna}

O Parque do Pantanal Matogrossense, abriga uma representativa amostra da fauna regional, incluindo espécies típicas de cerrado e banhados e áreas alagadas da bacia do Rio Paraguai. No meio terrestre, a fauna é dominada por herbivoros e no meio aquático, por peixes e seus predadores, principalmente as aves e os jacarés (Brasil, 1994)

\section{Mamíferos}

Predominam herbivoros de médio e grande porte, adaptados a vida semi-aquática, como a capivara (Hydrochaerus hydrochaerus), a anta (Tapirus terrestris ) e o cervo do Pantanal (Blastocerus dichotomus). Dentre os herbivoros arbóreos se destaca a abundância do bugio (Alouatta caraya). Encontra-se também a onça-pintada (Panthera onca) e a suçuarana (Felis concolor), a jaguatirica (Felis pardalis), ariranha (Pteronura brasiliensis), lontra (Lutra longicaudis), tamanduábandeira (Myrmecophaga tridactyla), o tatú-canastra (Priodontes giganteus), veadocampeiro (Ozotocerus bezoarticus), o tatu (Tolypeutes tricinctus), cachorro-do-matovinagre (Speothos venaticus) e o cachorro-do-mato (Dusicyon thous) (Brasil, 1994).

\section{Aves}

A concentração de aves é altíssima, não só pelo número de espécies mas pelo número de indivíduos de cada espécie. No Parque existem inúmeras espécies de garças (Ardeidae), tais como a garça-moura (Ardea cocol), garça-branca (Casmerodius albus), o socó-boi (Tigrisoma lineatum) e a garça-da-noite (Nyticorax nycticorax). Da familia Ciconidade, destacam-se por sua abundância, o cabeça-seca (Mycteria americana) e o tuiuiú (Jabiru micteria). Entre outras aves também abundantes estão incluídos o biguá (Phalacrocorax olivaceus), o colhereiro (Ajaia 
Figura 52 - Mapa de Vegetação do Parque Nacional e Áreas Adjacentes

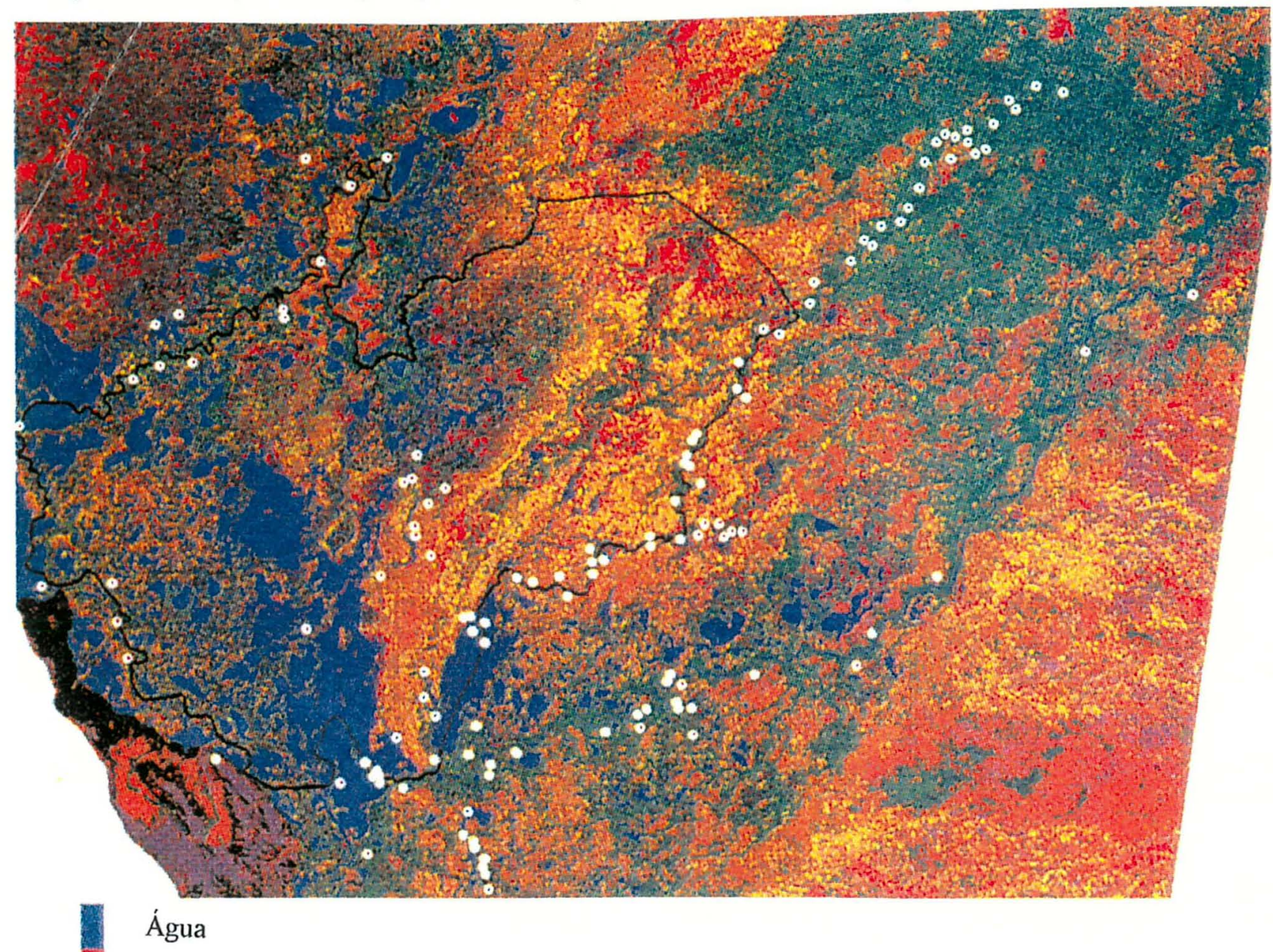

Batume

Camalotes

Campos inundáveis I

Campos Inundáveis II

Campos inundáveis com árvores esparsas.

Matas Abertas

Escala (kilometros)

Florestas inundáveis I

Florestas inundáveis II

Florestas inundáveis III

Florestas Semi-Decíduas

Vegetação seca esparsa

FBCN

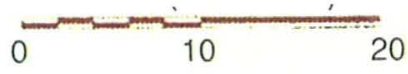

Limites do parque pontos de Observação

c ambas as estações

* somente estação úmida

- somente estação seca 
ajaja), a curicaca-real (Harpiprion caerulenses), e a curicaca comum (Theristicus caudatus) e várias espécies de Anatídeos. Comumente encontradas no Parque e seu entorno, o caracará (Polyborus plancus) e várias espécies de Psitacídios, como araras, inciuindo-se a ameaçada arara-azul (Anadorrhyncus hyacinthinus), papagaios e periquitos (Brasil, 1994).

\section{Répteis e Anfíbios}

O réptil mais característico do Parque é o jacaré (Caiman crocodilus yacare); outras espécies incluem a sucuri (Eunectes murinus.), assim como várias espécies de quelônios aquáticos. Sapos e rãs também aparecem no Parque, sendo um importante elo nesse ecossistema, consumindo grandes quantidades de insetos e por sua vez servindo de alimento para répteis e aves aquáticas (Brasil, 1994).

\section{Peixes}

Destacam-se entre as numerosas espécies de peixes que habitam a região: o pintado (Pseudoplatysoma comuscans), a cachara (Pseudoplatysoma fasciatum), o jaú (Paulicea luetkine), o barbado (Pinirampus pinirampu), o dourado (Salminus maxillosus), o pacú (Piaractus mesopotamicus), o curimbatá (Prochylodus lineatus), o piavuçu (Leporinus elongatus), e as várias espécies de piranhas (Serrasalmus sp.) (Brasil, 1994)

\section{V.3. Ocorrência de fenômenos naturais e suas consequências}

\section{O Comportamento das Enchentes}

Ainda hoje, é pouco conhecida a complexidade da dinâmica fluvial do Pantanal do Paiaguás, onde estão aglutinados diversos aluviōes e como o processo pluvial interfere na fisionomia da paisagem (Brasil, 1994).

Em 1862, fora constatada que as cheias à juzante das Lagoas Gaíva e Uberaba, são mais tardias em relação ao norte da bacia, alcançando em julho seu maior nível. Cientistas observaram que o declive leste-oeste, no pantanal do Paiaguás é mais acentuado do que o norte-sul, permitindo-se a conclusão que as águas dos 
afluentes chegam ao eixo norte-sul do Rio Paraguai, com mais energia do que sua capacidade de escoamento. Essa diferença de gradiente topográfico causa o constante alagamento da área. Concluindo-se que as inundações da área do Parque, decorrem do volume de água captado pela rede de afluentes do Rio Paraguai, do que pela própria pluviosidade da região (Brasil, 1994).

A dinâmica das enchentes influencia diretamente 0 Parque e seu entorno, uma vez que a Unidade se localiza na área de ocorrência das mais acentuadas e abrangentes inundações de toda a bacia do Alto Paraguai (Brasil, 1994).

Segundo dados do REA, 1992, cerca de $27 \%$ da área total do Parque Nacional se encontra permanentemente alagada, enquanto outros $47 \%$ estão sujeitos a alagamentos periódicos durante a época das enchentes, que força a grande maioria da mastofauna e cerca de $27 \%$ da avifauna do Parque Nacional a migrar para terras altas no seu entorno. Atualmente essas áreas foram adquiridas e transformadas em Reserva Particular do Patrimônio Natural, de propriedade da ONG Fundação de Apoio à Vida nos Trópicos (ECOTRÓPICA), em 1997.

\section{V.4. Características Sócio-Econômicas e culturais}

\section{V.4.1. Situação fundiária}

O Parque Nacional do Pantanal Matogrossense tem situação fundiária totalmente regularizada, com a aquisição integral por parte do Governo Federal da antiga Fazenda Caracará, embora ainda não se encontre demarcado. Não existem posseiros ou residentes na área do Parque, exceto dois únicos residentes, identificados e reconhecidos pela FUNAI como remanescentes do Grupo Guató. Moram em precária habitação de sapé na base do Morro do Caracará, nos limites do Parque (Brasil, 1994). 
Figura 53 - Localização das áreas da Fundação Ecotrópica transformadas em RPPN

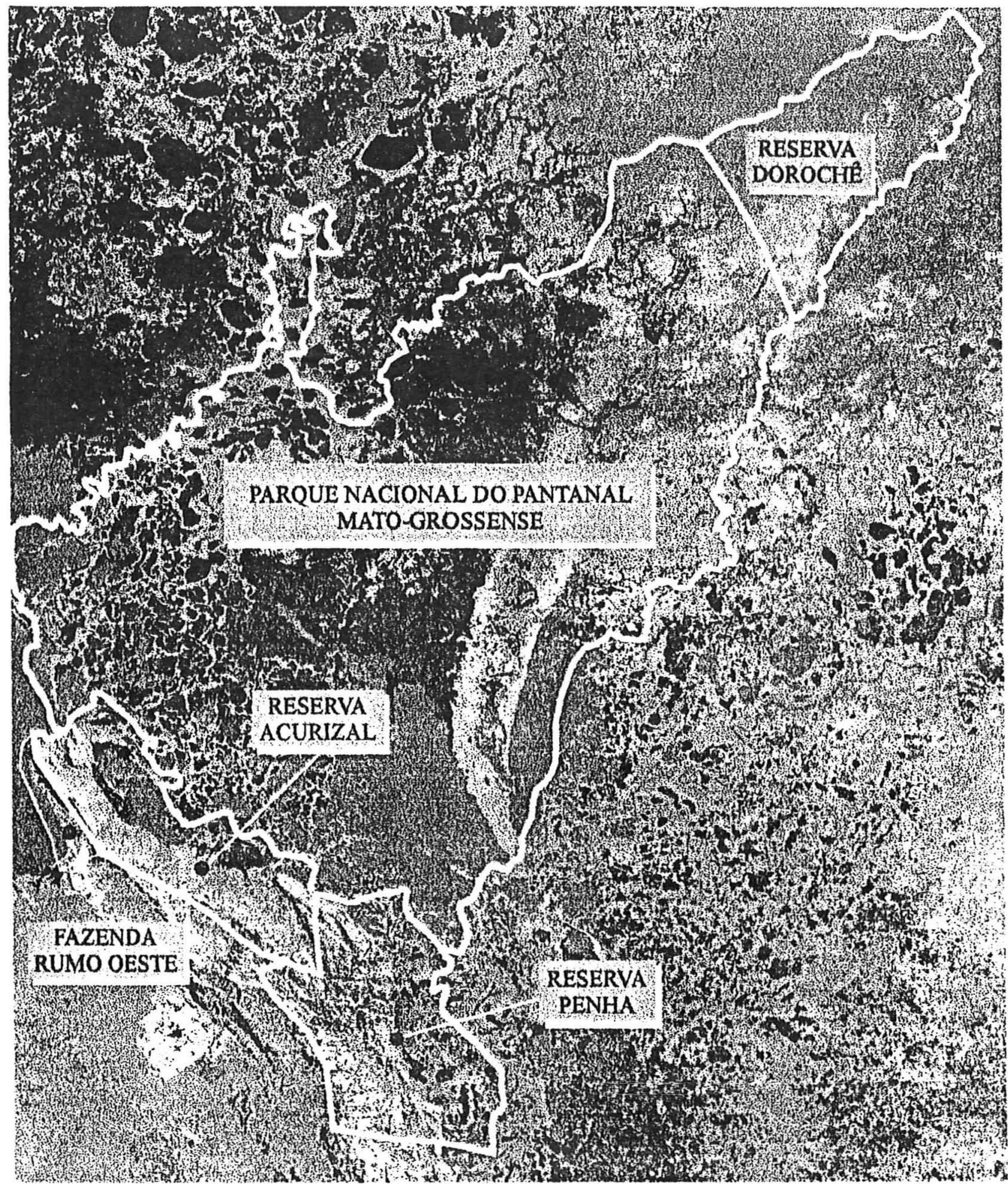




\section{V.4.2. Uso do Parna}

Até 1974, a área ocupada pelo atual Parque Nacional, foi uma fazenda produtiva de criação de gado, em sistema de rodízio de pastagem, utilizando espécies gramíneas nativas. Esse sistema agropecuário não causa significativo impacto negativo ao ecossistema, pois utiliza baixas densidades de gado, permitindo que as pastagens naturais se recuperem periodicamente. Até hoje, as fazendas vizinhas utilizam esse sistema extensivo de pecuária, onde se observa, convivendo com o gado, cervos, capivaras, antas, tamanduás e aves (Brasil, 1994).

$\mathrm{Na}$ área do Parque Nacional, a maior parte das antigas pastagens se encontram alagadas e as que permanecem secas, se encontram ocupadas pela flora e fauna nativas da região, pois ao longo desses 20 anos, percebe-se uma certa regeneração no ecossistema local (Brasil, 1994).

Os dois únicos residentes no Parque Nacional, índios reconhecidos como remanescentes do Grupo Guató (figura 54), moram em habitação precária, no limite do Parque, exercendo atividade de subsistência de forma completamente artesanal, utilizando facão e zagaia, caçam capivaras e veados, pescando de forma oportunista. Possuem cerca de uma dezena de cães, visivelmente em mau estado de saúde (Brasil, 1994).

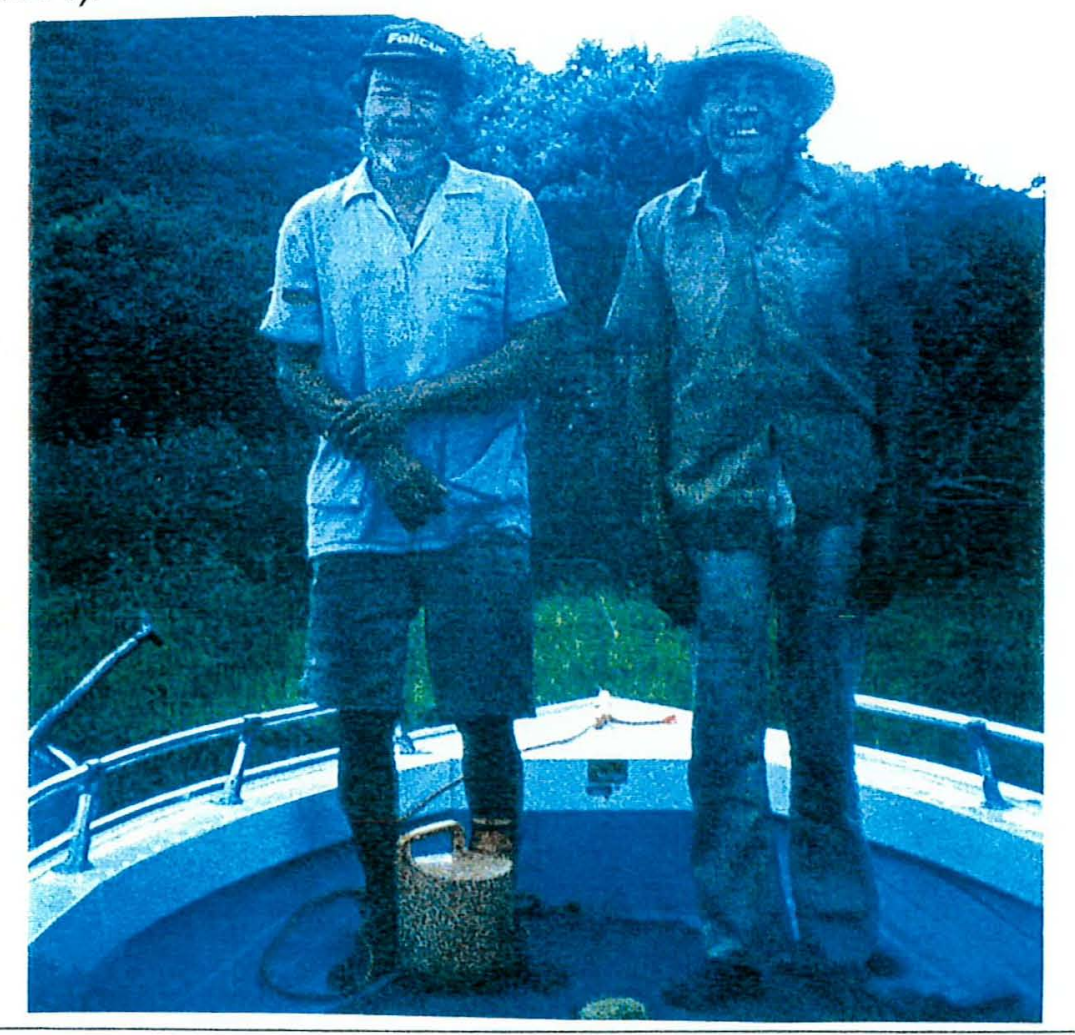

Figura 54 - Dois remanescentes Guatós, Sr. José e Sr. Veridiano 
No Parque prevalecem usos indevidos, sendo os mais significativos:

(i) A Pesca que divide-se em duas categorias: a praticada pelos habitantes da região e a pesca praticada por pescadores comerciais e amadores que visitam a região. Essa atividade que ocorre no Parque Nacional e no seu entorno é ilegal e sem controle.

Os habitantes locais, pescam nos rios do entorno do Parque, nos Rios Paraguai, Cuiabá, São Lourenço e Caracará e provavelmente em áreas interiores, utilizando canoas e equipamentos artesanais. Ressaltando-se aqui a atuação do "Seu" Benjamim, Chefe Substituto do Parque, que ao longo dos anos de bom relacionamento com os moradores da região, convence a maioria deles a não pescar dentro da área do Parque, sobretudo evitando o uso de equipamentos considerados ilegais.

A modalidade de pesca que mais danos causa a Unidade de Conservação, é a praticada ilegalmente por pescadores profissionais, que capturam grandes quantidades de pescado para revenda, também praticada por alguns pescadores amadores. As embarcações partem de Porto Jofre (MT) e Corumbá (MS), transportando grande quantidade de voadeiras com motor de popa, chegando até 20 por embarcação, ganhando acesso rápido a pontos de pesca no interior do Parque e seu entorno.

Como o Parque não possui sinalização, principalmente em seus limites, os pescadores quando abordados, alegam desconhecimento da existência do Parque e dos seus limites.

Os principais pontos de penetração no Parque pelas embarcacões são: Porto das Três Bocas, Fazenda Bela Vista do Norte e Baía do Burro.

(ii) Impacto das Embarcações, que com seus motores de popa geram marolas que causam a erosão das margens dos canais e rios, contribuindo para o assoreamento, principalmente dos corixos.

(iii) Impacto da Pesca na Avifauna, muitos pesqueiros coincidem, com ninhais e a constante movimentação de pescadores nesses locais, estressam as aves, causando 0 abandono dos ninhos, facilitando, que aves de rapina devorem 
seus ovos e filhotes. Evidencia-se tal fato, no ninhal localizado na entrada do Rio Negrinho (figura 55), já próximo ao Parque, causando a diminuição de aves, desde que o local passou a ser freqüentado por um número crescente de pescadores. (Figura 56).

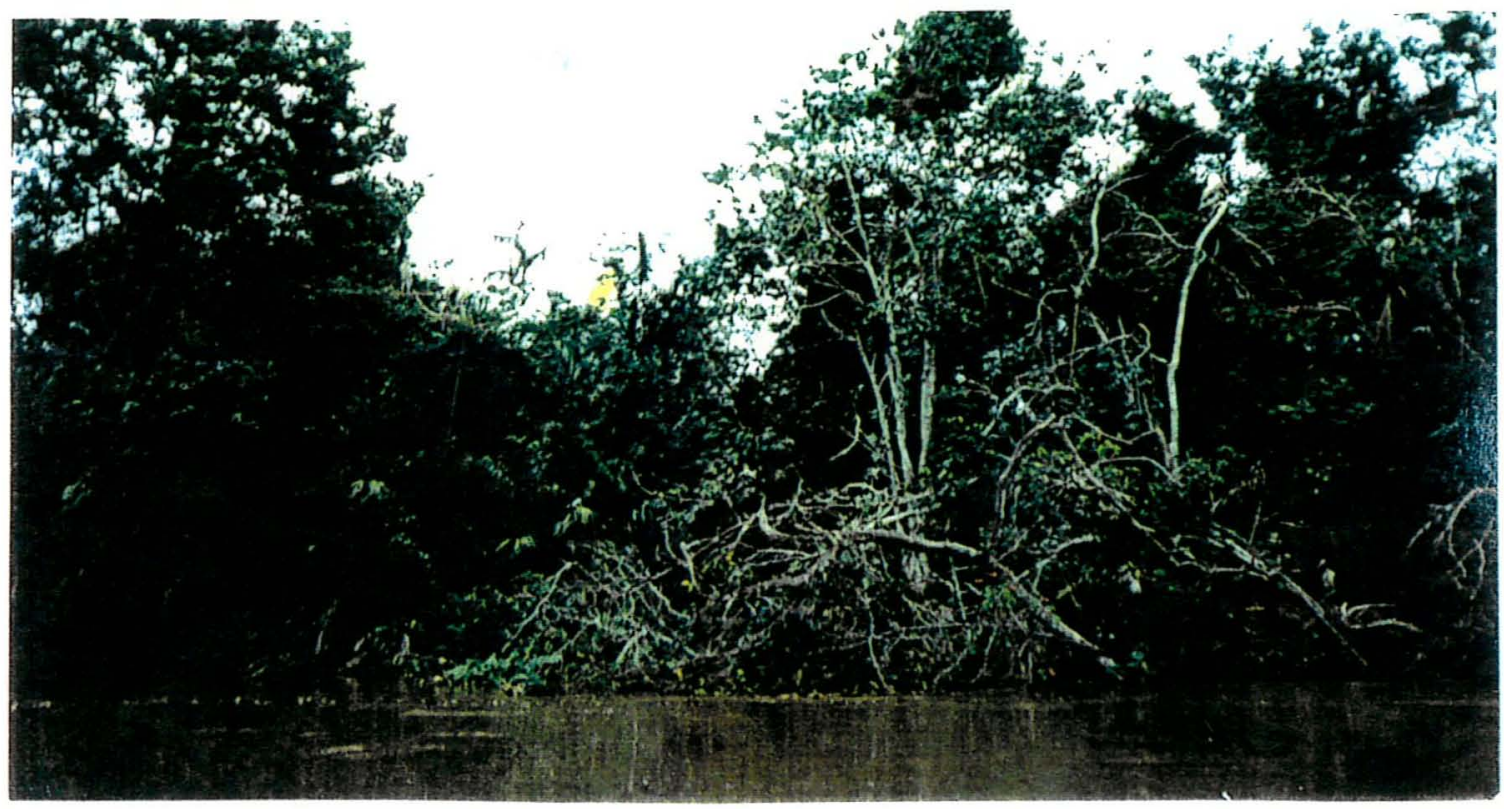

Figura 55 - Aspectos geral do Ninhal do Rio Negrinho, no entorno do Parque.

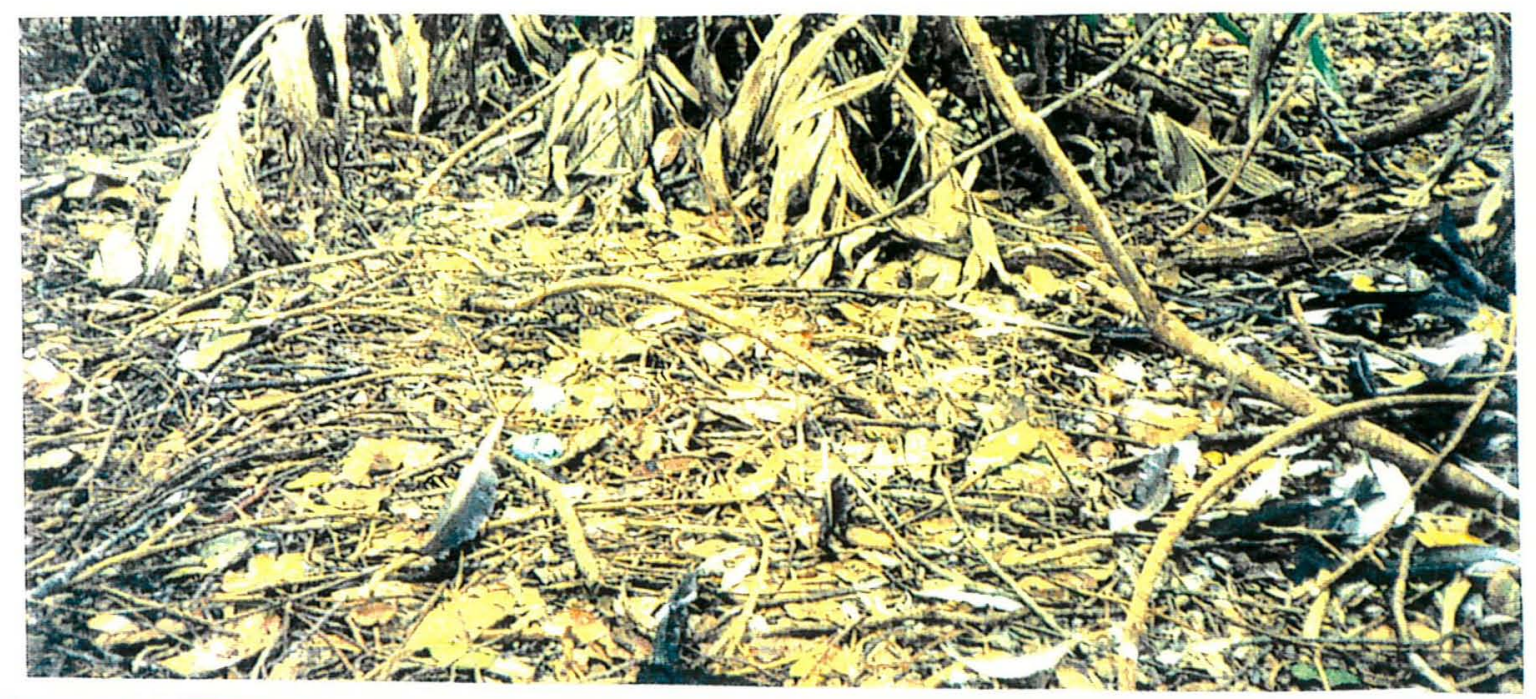

Figura 56 - Vista da grande quantidade de ovos caidos dos ninhos. 


\section{V.4.3. Histórico de Ocupação da Região}

Por volta de 1550 , os espanhóis vindos pela Bolívia, provavelmente foram os primeiros europeus a pisarem solo pantaneiro. Os primeiros arquivos portugueses a fazer menção do pantanal, no final do século $X V I$, denominaram-no de "Mar do Xaraés", e observaram o fato de que estes índios já usavam cavalos como meio de transporte, e o tinham adaptado às condições pantaneiras. Dessa forma, a montaria viria a moldar as bases das tradições pantaneiras e facilitar 0 desenvolvimento da região (Brasil, 1994).

Quando a cultura contemporânea, surge com o advento da pecuária e seus latifúndios, aparece a figura do "peão-de-boiadeiro", que com suas tradicões, vestes, música e estilo de vida isolada e remota, forma durante este século o estereótipo do homem e da vida no Pantanal. Na região do Parque são fortes os laços de ligação do homem à terra. No entanto, com a modernização do Pantanal, o advento do turismo, do garimpo e da pesca comercial, as tradições começam a mudar. Hoje, muitas antigas famílias começam a se deslocar para centros urbanos a fim de aumentar as oportunidades e dar condições de estudo para seus filhos, desmembrando dessa forma as famílias, permanecendo nas fazendas, apenas os mais velhos (Brasil, 1994).

\section{V.4.4. Aspectos Culturais}

Foi constatada a existência de inscrições rupestres antigas no Parque, localizadas no topo do Morro do Caracará, local de difícil acesso por trilha íngreme. Os índios residentes desconhecem o significado e a origem dessas inscricões. Desenhos com padrões semelhantes podem ser observados na entrada da baia Gaiva, encrustados em rochas, parcialmente submersas. (Figura 57). 


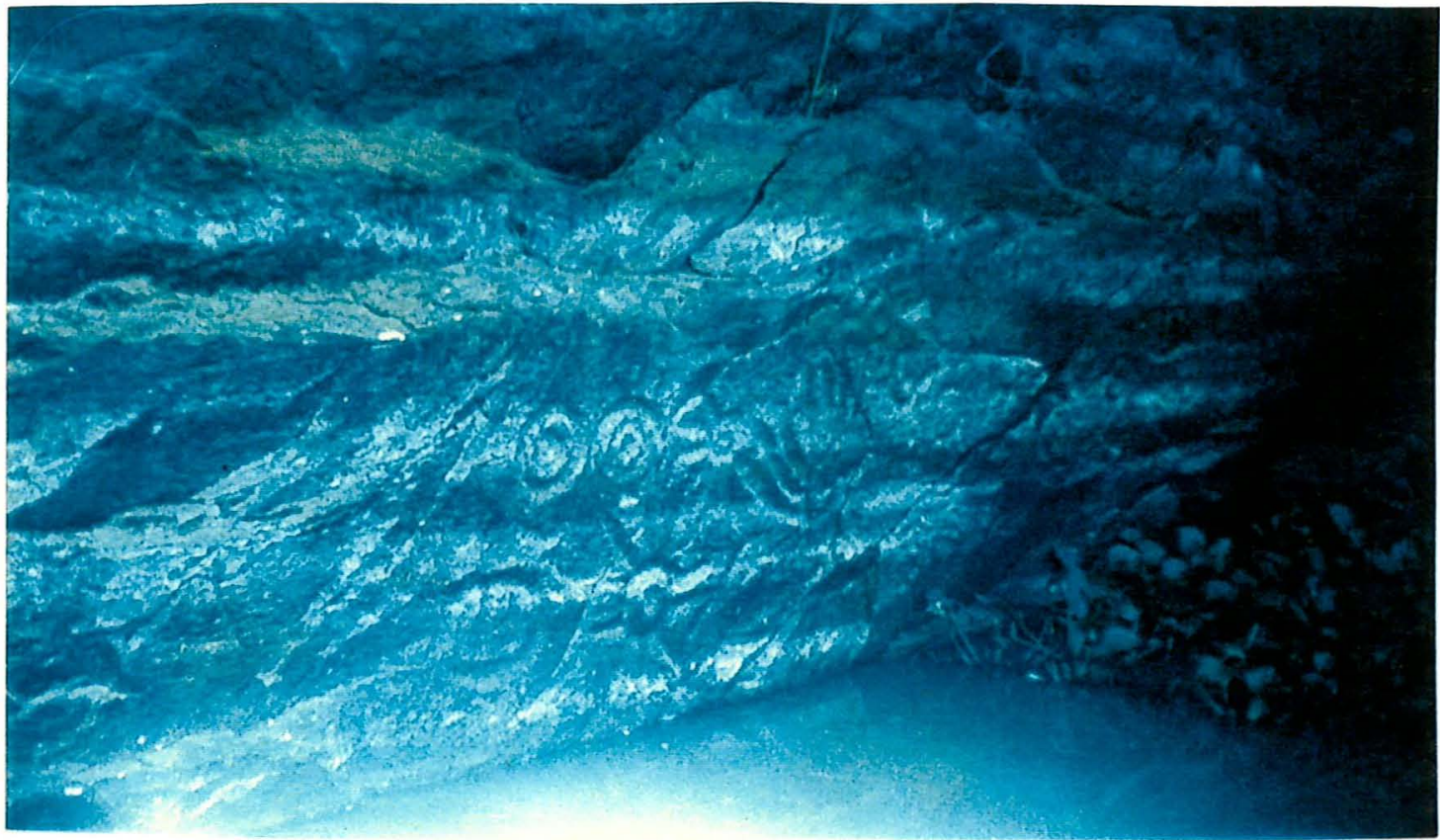

Figura 57 - Inscrições observadas na entrada da Baia Gaiva, parcialmente submersas.

\section{V.5. Área de influência do.Parque Nacional}

No caso do Parque Nacional, o entorno consiste no cinturão de $10 \mathrm{~km}$, das cidades de Poconé, Corumbá (à jusante da Unidade) e das bacias hidrográficas dos Rios Paraguai e Cuiabá, cujas águas o delimitam.

\section{V.5.1. Faixa do entorno de $10 \mathrm{~km}$}

O Parque Nacional possui no seu entorno as seguintes fazendas: Fazenda Belica e Fazenda Talita, ambas no Rio Cuiabá; Fazenda Doroché, no Rio Caracará; Fazenda Acurizal, na Serra do Amolar e Fazenda Bela Vista, ao norte do Parque. O acesso a essas propriedades é realizado somente por barco ou avião; predominando em todas elas, a pecuária. São todas grandes propriedades, que pertencem a tradicionais famílias de pecuaristas da região, que praticam a pecuária extensiva, com rotação de pastagens. Porém recentemente, algumas fazendas foram divididas entre os descendentes de antigos fazendeiros, possibilitando a venda e desmembramento, surgindo assim, propriedades menores, que não viabilizam a 
criação em regime extensivo ao redor do Parque, facilitando a aquisição por parte da ONG ECOTROPICA, de 03 fazendas lindeiras ao Parque: a Fazenda Dorochê com 26. 518 ha, no Município de Poconé/MT e das fazendas Acurizal com 13.200 ha e Penha de 13.100 ha, situadas no Município de Corumbá/MS, transformadas em Reservas Particulares do Patrimônio Natural, através das Portarias $n^{\circ} 06$ e 07 de 19 de fevereiro de 1997, respectivamente. Vide figura 53.

A estrutura das fazendas, vem sofrendo mudanças, com a introdução da atividade turística, como alternativa econômica, com o estabelecimento de pousadas, pescarias e passeios ecológicos aos visitantes, uma vez que, ainda conservam em suas terras muitas características naturais, devido ao sistema extensivo de criação utilizado. Muitas vezes, os proprietários tradicionais, tomam medidas de proteção, como a inibição da atuação dos coureiros em suas propriedades (Brasil, 1994).

O impacto ambiental causado pela pecuária na região, é devido ao manejo das pastagens, utilizando-se do fogo, que muitas vezes se alastra por propriedades vizinhas, ou pelas matas nativas. O Parque Nacional não é afetado por esse problema, uma vez que a maior parte de sua área, permanece inundada ou encharcada na época das queimadas.

\section{V.5.2. Cidades de Poconé e Corumbá}

\section{Poconé}

Cidade criada em função da atividade mineradora, em 1777, além da pecuária extensiva praticada na região e que durante a Guerra do Paraguai, teve relevante papel de fornecedor de gado e cavalos, para alimentação e transporte, das tropas brasileiras (EMPAER, 1996f).

A economia do Município passa hoje por um processo de dinamização em diversos níveis, a fim de integrar-se à economia de mercado da região. A aglomeração urbana caracteriza-se por apresentar uma estrutura produtiva com base na atividade garimpeira e uma estrutura diversificada de serviços. De acordo com dados levantados, cerca de $10 \%$ da população trabalha nos garimpos, enquanto que 
o restante presta serviços direta ou indiretamente ligados a esta atividade (EMPAER, 1996f).

Atualmente a agricultura na região está estabilizada, exceto a cultura da cana-de-açúcar, que deverá atingir uma área cultivada de 9.000 ha, nos próximos 03 anos, devido a existência de Usina Alcooleira da região. As lavouras de arroz, milho, feijão são cultivadas quase que exclusivamente para a subsistência nas comunidades rurais. A cultura da mandioca teve decréscimo de área plantada devido ao fechamento da fecularia (EMPAER, 1996f).

O Municipio possui hoje, um rebanho em torno de 270.000 cabeças, e a situação do pecuarista pantaneiro está sendo dificultada, em virtude da contínua descapitalização do setor e devido a grande cheia de 1995, diminuindo a taxa de natalidade do rebanho para 35\% (EMPAER, 1996f).

Outra atividade que vem crescendo de importância para o Município é o turismo. Distando da capital cerca de $100 \mathrm{~km}$ por rodovia asfaltada, com localização privilegiada, torna-se um pólo de atração de turistas. É passagem obrigatória para Porto Jofre, depois de se percorrer 135 km, ao longo da Rodovia Transpantaneira (atualmente transformada em Estrada-Parque, a partir do $\mathrm{Km} \mathrm{16}$, pelo Governo Estadual Matogrossense), divisa do Estados de Mato Grosso com Mato Grosso do Sul.

\section{Corumbá}

Situa-se as margens do Rio Paraguai, via natural de circulação desde 0 século XIX, representando importante papel na articulação do espaço regional, permitindo o acesso a Cuiabá e viabilizando o comércio importador e exportador dos produtos mato-grosossenses através da Bacia Platina.

\section{Aspectos Sócio-Econômicos}

A economia da região apoia-se na agropecuária de corte, desenvolvida e adaptada às condições ecológicas locais e no desenvolvimento do turismo.

Até meados do século, o gado do pantanal era abatido e transportado em forma de charque e couro exportado para fora do Estado. Até a década de 50 , 
Corumbá, dispunha de importante indústria saladeira. Com a construção da ferrovia, na década de 20, ligando Campo Grande a Corumbá, e posterior implantação-da atual Rodovia BR 262, houve um estímulo aos fazendeiros no investimento da qualidade genética do rebanho, introduzindo o gado Nelore e Gir, que predominam na região. Atualmente o comércio de gado em pé, destina-se as invernadas na própria área, que vai de Campo Grande ao Oeste Paulista (Brasil, 1994).

Corumbá não possui mais a função de empório comercial que the deu prestígio no final do século XIX e até meados do séc XX. Hoje é um porto fluvial, muito ligado ao turismo, com desenvolvida hotelaria e de onde partem as embarcações de várias empresas do setor. Contando com uma frota de 42 embarcações com 70 lugares cada, adentram o pantanal, atendendo aos turistas nacionais (e em menor escala, estrangeiros), que dentre outras atividades, são atraídos pela pesca (Brasil, 1994).

\section{V.5.3. Águas à montante do Parque Nacional}

As águas que inundam o Parque Nacional provém dos Rios da Bacia do Alto Paraguai, principalmente dos rios Paraguai e Cuiabá, devendo ser considerada como área de influência da Unidade, assim como as atividades neles ocorrida.

Devido as profundas transformações, a partir da década de 60 , na região das nascentes dos rios da bacia do Alto Paraguai em face da adoção de políticas de incentivos, por parte do Governo Federal, voltadas para a expansão da fronteira agrícola, onde foram implantados projetos com colonos provenientes da região sul do país,organizados principalmente em cooperativas e introdutores da cultura de grãos a partir da década de 70 , atraindo grandes empresas agropecuárias, com capital e práticas extrativistas, predatórias ao meio ambiente, resultando em altos indices de erosão dos solos, agrotóxicos e sedimentos, despejados nos leito dos rios a montante de todo o pantanal.

Na bacia do Alto Paraguai, são praticadas três modalidades de pesca: a artesanal de subsistência, a comercial e a esportiva. As modalidades mais importantes sobre o ponto de vista de impacto sobre o Parque Nacional, são as 
pescas, comercial e a esportiva, mais atrativas para os turistas, constituindo-se em importante atividade econômica através da geração de empregos na área de influência do Parque Nacional (Brasil, 1994).

\section{Poluição industrial e urbana}

A maior parte das águas de inundação do Parque Nacional, provém do Rio Cuiabá, do qual saem braços denominados Rios Alegre e Caracará, que cruzam o Parque, alimentando suas lagoas e áreas alagadas. Suas águas determinam a qualidade dos habitats do Parque.

O Rio Cuiabá cruza a cidade de Cuiabá, recebendo seus esgotos domésticos e industriais quase sem tratamento, e já em Porto Jofre, recebe as águas do São Lourenço, que trazem também efluentes gerados da cidade de Rondonópolis e região. Também recebe águas provenientes da região de Poconé, que trazem efluentes contaminados por mercúrio, gerados pelos 3.000 garimpos de ouro que operam na região (Brasil, 1994).

\section{V.6.Aspectos Institucionais}

\section{V.6.1.Infra-estrutura}

Atualmente o Parque Nacional possui as seguintes estruturas: a sede da Unidade e a casa do Funcionário, munidas de rádio, gerador, com capacidade de acomodação para até 15 pessoas, construções recém-reformadas. Vide figura 58. 


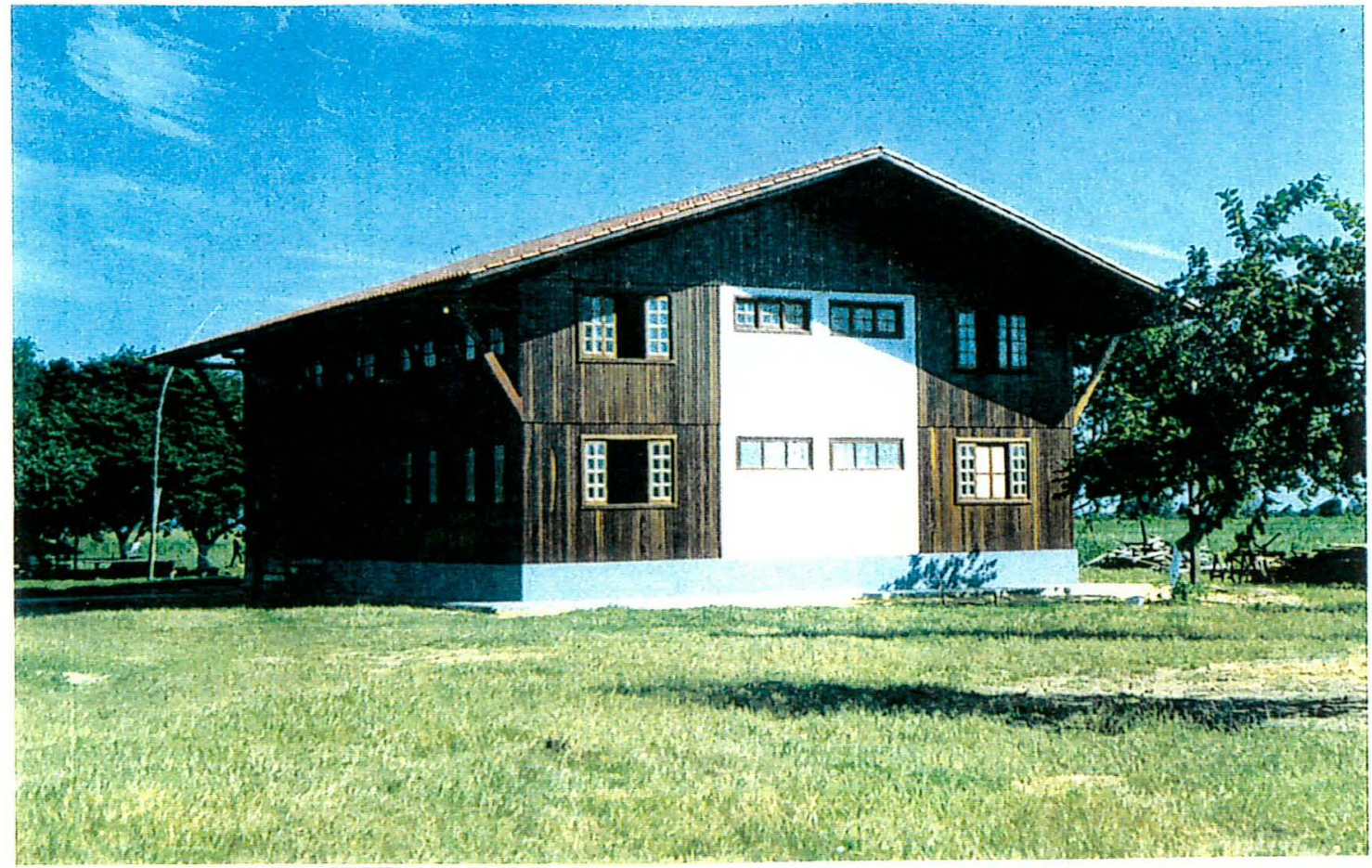

Figura 58 - Sede do PARNA do Pantanal Matogrossense recém reformado.

A sede do Parque foi construída sobre um aterro, feito ainda pelo antigo proprietário da fazenda, embora se tenha mantido neste alguma infra-estrutura (sede equipada e embarcações). (Figura 59).

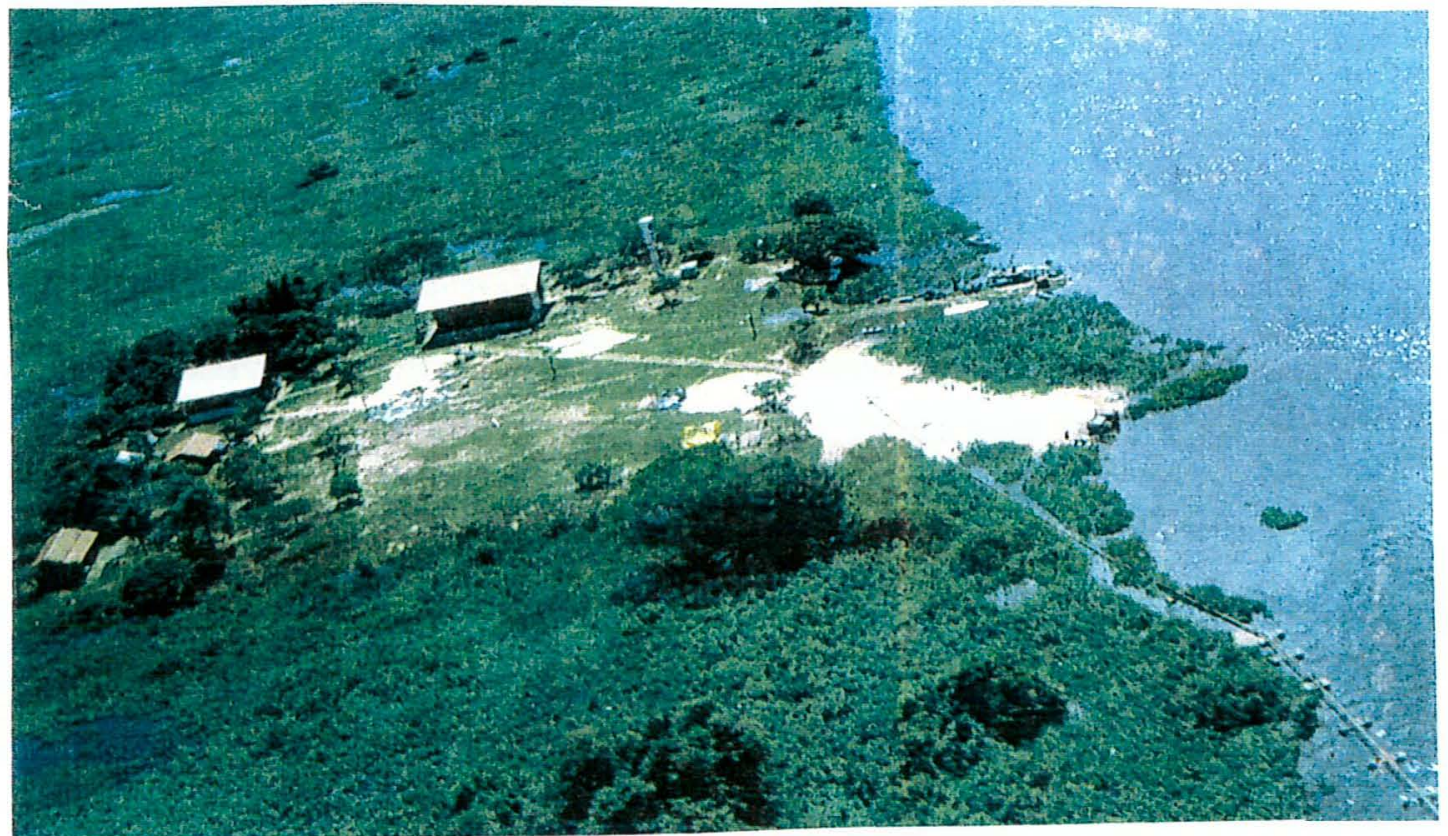

Figura 59 - Vista aérea da sede onde se observa o aterro recém reformado. 
Possui um atracadouro flutuante, que pode se transformar em embarcação, quando necessário. Contando com 10 painéis solares e gerador, para a produção de energia elétrica. Figura 60.

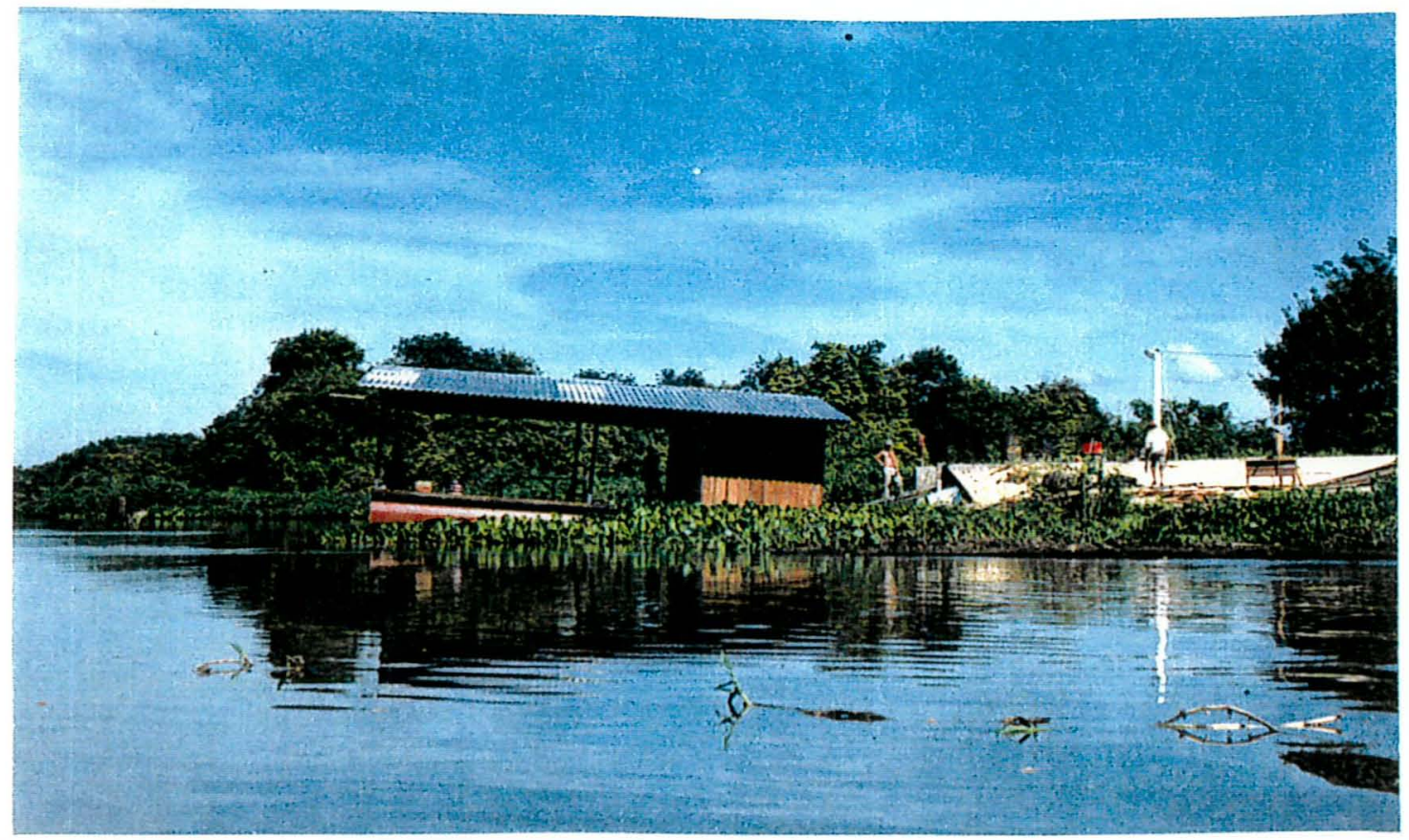

Figura 60 - Porto flutuante que pode ser transformado em embarcação.

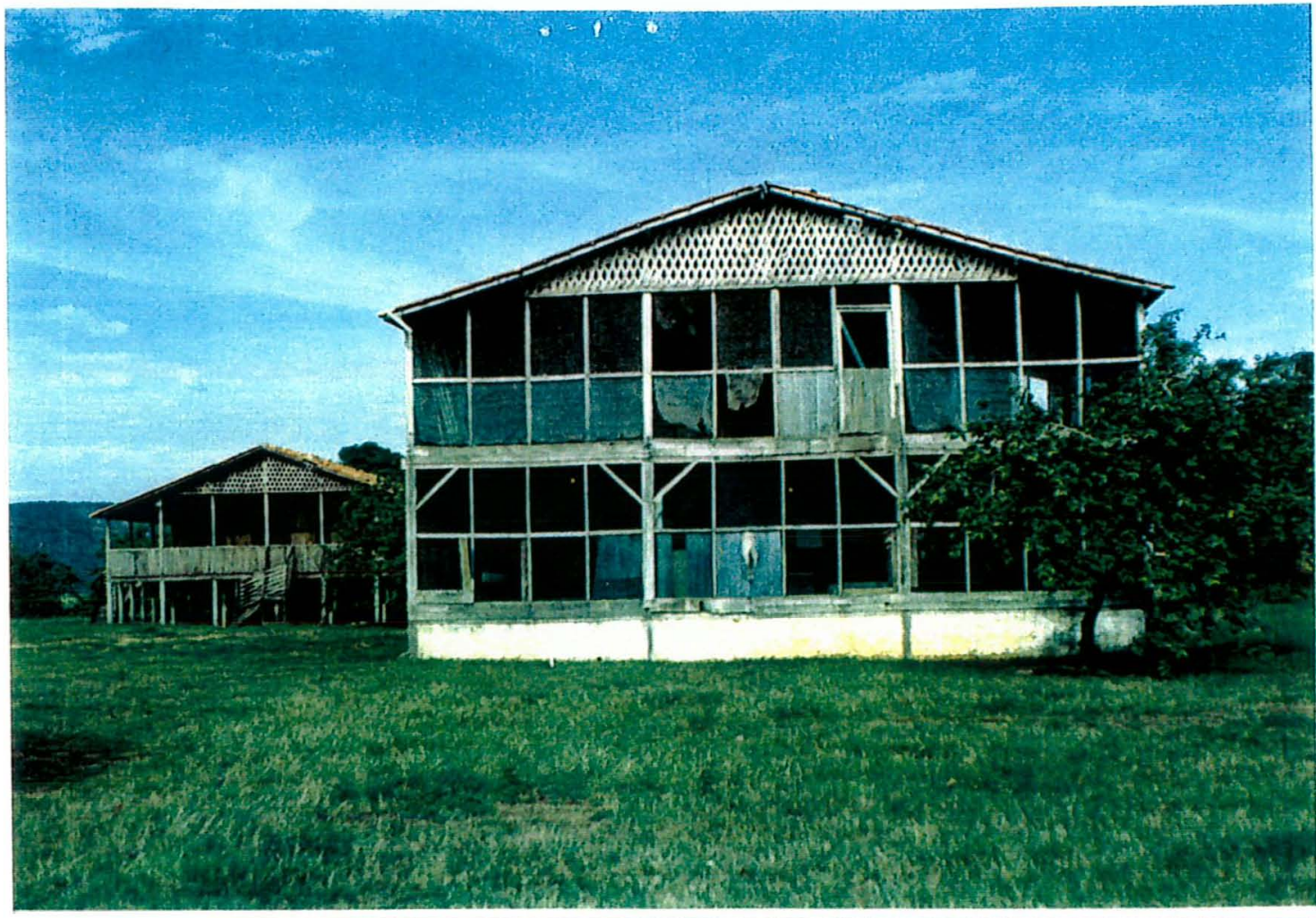




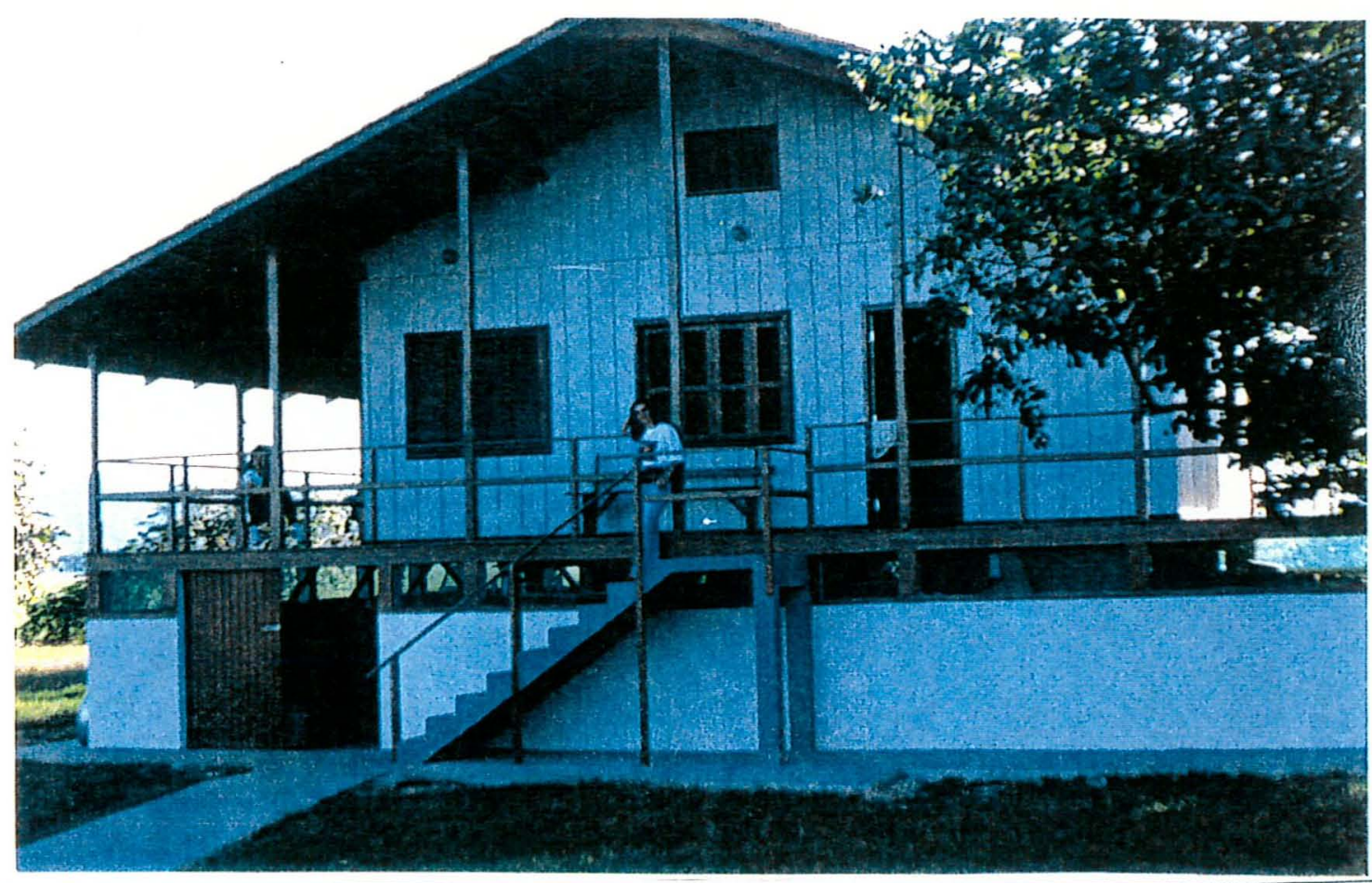

Figura 62 - Casa do funcionário após a reforma.

4.V.6.2.PESSOAL

Tabela 06 - Quadro de pessoal do PARNA Pantanal Matogrossense

\begin{tabular}{|c|c|c|c|c|}
\hline Função/Cargo & $\begin{array}{l}\text { Portaria / } \\
\text { Nomeação }\end{array}$ & $\begin{array}{c}\text { Anol } \\
\text { nascimento }\end{array}$ & Escolaridade & Cursos/área \\
\hline 1. Chefe do Parque & $\begin{array}{lll}\text { Portaria } & 0136 / 96 \text { de } \\
30 / 01 / 96 & & \\
& & \end{array}$ & 1950 & $\begin{array}{l}\text { Superior } \\
\text { incompleto }\end{array}$ & $\begin{array}{c}\text { Gerenciamento } \\
\text { Planejamento de UC } \\
03 \text { a18/05/94 }\end{array}$ \\
\hline $\begin{array}{l}\text { 2.Agente Ativ. } \\
\text { Agropecuárias } \\
\text { Chefe Substituto }\end{array}$ & $\begin{array}{l}\text { Tab. Esp. } \\
\text { DOU 13/05/81 } \\
\text { Portaria 1765/93 }\end{array}$ & 1941 & $\begin{array}{l}\text { I Grau } \\
\text { completo }\end{array}$ & $\begin{array}{l}\text { Cap. Pessoal } \\
\text { Fiscaliz. UC na } \\
\text { Amazonia Legal }\end{array}$ \\
\hline $\begin{array}{l}\text { 3. Aux. Op. Serviços } \\
\text { Diversos * } \\
* \star\end{array}$ & $394 / 90$ & 1945 & $\begin{array}{l}\text { I Grau } \\
\text { completo }\end{array}$ & \\
\hline $\begin{array}{l}\text { 4. Aux. Op. Serviços } \\
\text { Diversos * } \\
* *\end{array}$ & Tab. Esp. De 01/09/83 & 1949 & $\begin{array}{c}\text { I Grau } \\
\text { completo }\end{array}$ & \\
\hline
\end{tabular}

*-Contratado por tempo determinado pela Portaria 394/90 de 14/03/90 - Tabela especial e posicionamento pela portaria 542 de 16/04/93.

** Lotado no Parque, mas näo presta serviço nesta Unidade. 


\section{V.7. Considerações}

O Parque Nacional do Pantanal Matogrossense está localizado junto à divisa dos Estados de Mato Grosso e Mato Grosso do Sul, e os turistas que chegam de Corumbá para as pescarias, causam sérios transtornos à fiscalização da Unidade, que é realizada somente por via fluvial, contando um funcionário para os138.000 ha.

A Unidade possui a maior parte de sua área coberta por água ou inundada, levando com isso a fauna procurar abrigo nos entornos, que ficavam fora do Parque. Parecendo que o problema foi resolvido com a aquisição dessas áreas pela ONG Ecotrópica para transformá-las em RPPN's.

Atualmente, numa tentativa de gestão compartilhada, as entidades Ecotrópica e IBAMA estão trabalhando para a realização de um Plano de Manejo único para as três áreas.

A Hidrovia Paraguai-Paraná que propõe mudanças drásticas no Rio Paraguai, justamente no trecho em que está inserida a Unidades de Conservação e as Reservas Particulares do Patrimônio Natural, sem nenhuma consulta e participação dos seus Órgãos gestores.

A região possui inúmeros atributos, entre eles vários sítios arqueológicos praticamente desconhecidos, que podem vir a desaparecer com a mudança hidrológica da área.

A Unidade passou por reformas e tem condições para receber pesquisadores em sua sede.

Uma das necessidades mais prementes é o aumento do número de funcionários, aquisição de equipamentos adequados à fiscalização na região, bem como ações de educação ambiental no entorno da Unidade e junto aos "turistas", que passam por suas águas. Pois apesar de todo um trabalho junto às companhias de turismo, os "turistas" alegam desconhecimento da Unidade de Conservação. 


\section{V.8. Síntese sobre a criação das Unidades de Conservação do Estado de Mato Grosso}

O resgate histórico do Estado de Mato Grosso indica que a primeira Unidade de Conservação criada foi a Reserva Florestal de Juruena em 1961, através do Decreto no 51.027/61, com uma área de 1.808 .000 ha, situada entre os rios Juruena e Arinos, ao norte do Estado, com limite sul no paralelo $12^{\circ} \mathrm{com}$ predomínio da Floresta Estacional Semidecidual Tropical Submontana de dossel emergente. A implementação e os estudos ficaram a cargo da antiga SPEVEA (Superintendência do Plano de Valorização da Amazônia) com o apoio do Serviço Florestal do Ministério da Agricultura.

Esta Unidade de Conservação não foi implementada até a presente data, e em 1980, encontrava-se ocupada por cerca de 28 grandes propriedades e pelo menos 21 campos de pouso dentro da área, ligadas por terra a Porto dos Gaúchos. Os proprietários utilizaram-se do fogo para suas atividades, contribuindo com a redução da diversidade na região, perdendo a razão de existir com uma área tão grande. Chegou a ser ventilada a proposta de uma área de 586.700 ha por parte da FEMAIPRODEAGRO, não representando ser prioridade para os Órgãos Ambientais nem para os agentes finaciadores.

Em 1974, no II PND (Plano Nacional de Desenvolvimento), através da Lei no $6.151 / 74$ foi criada a Reserva Ecológica Apiacá, localizada na porção setentrional do Estado, entre os rios Teles Pires e Juruena, num total de 1.513 .000 ha, apresentando os seguintes tipos florestais em ordem decrescente: Floresta Ombrófila Aberta Tropical Submontana com palmeiras, Floresta Estacional Decidual Tropical de Dossel Emergente, Savana Arbórea Densa (Cerradão), Savana Arbórea Aberta (cerrado) e Savana Parque, representando grande variedade de ecossistemas e riqueza faunistica (Brasil, 1980).

No documento "Pólo Juruena" da SUDECO, foi recomendado que a Reserva Apiacá, viesse a se tornar uma Estação Ecológica, sob responsabilidade da SEMA, que vinha estudando a área desde 1977 (Brasil, 1980). Atualmente está sob gestão da FEMA/MT (Fundação Estadual do Meio Ambiente), na forma de Reserva Ecológica, com grande redução da área proposta anteriormente. 
A proposta precursora de criação de Unidades de Conservação, baseada em critérios científicos foi apresentada por Brown, em 1970, que sugeriu a implantação de uma Reserva Biológica em Chapada dos Guimarães. No ano seguinte, em 1971 foi criada a Reserva Biológica do Caracará, primeira Unidade de Conservação no ecossistema pantaneiro, na divisa dos Estados de Mato Grosso e Mato Grosso do Sul.

Posteriormente, em 1981 foi lançada a "Proposta de Preservação do Morro de Santo Antônio" pelos alunos e docentes da Universidade Federal de Mato Grosso, que não alcançou seus objetivos de criação.

As Estações Ecológicas de Iquê-Juruena, Taiamã e a Estação Ecológica Serra das Araras, criadas em 1981 e 1982, respectivamente, foram implantadas pela SEMA (Secretaria Especial do Meio Ambiente), dentro do Plano I (1979) e Plano II (1981) do Sistema de Unidades de Conservação do Brasil, programas que promoveram a identificação das áreas prioritárias para fins de conservação, baseando-se em critérios ecológicos $e$ se pautaram na representatividade dos ecossistemas, tipos de paisagens, endemismos ou em áreas de refúgio.

Também em 1981, foi criado, pelo antigo IBDF (Instituto Brasileiro de Desenvolvimento Floresta) o Parque Nacional do Pantanal Matogrossense, englobando a área da Reserva Biológia do Caracará.

Havia uma certa "competição " positiva entre o IBDF e a SEMA, que possuia o que se pode chamar de uma rede paralela de Unidades de Conservação na forma de Estações Ecológicas e APA's, porém com grande diferença, pois as Estações Ecológicas, logo após sua criação eram dotadas de infra-estrutura básica necessária, inclusive com campo de pouso para bimotores e uma rede de comunicação, bem como com um certo número de funcionários

Em 1989, depois de intensa luta da sociedade organizada, que desde 1984 já discutia um esboço da "Proposta para Criação do Parque Nacional de Chapada dos Guimarães" representada pelas ONG's: ARCA (Associação para Recuperação e Conservação Ambiental) e AME (Associação Mato-grossense de Ecologia) foi criado o Parque Nacional da Chapada dos Guimarães. 
Ao nivel Estadual a criação de Unidades de Conservação teve início no final da década de 70 , mais precisamente em 1978, com a a criação do Parque Estadual de Águas Quentes e onze anos após, em 1989, criou-se a Reserva Estadual do Culuene, ambas Unidades com áreas bastante reduzidas, como se pode observar na tabela 07.

Após a implantação do PRODEAGRO (Programa de Desenvolvimento Agroambiental) em 1992, no Estado de Mato Grosso, partindo-se das informações do zoneamento agroecológico iniciado na etapa final do POLONOROESTE, foram selecionadas as áreas de atuação e com elas, a implantação e vigilância de Unidades de Conservação. O programa exerceu grande influência tanto em nivel Estadual, com a criação da DUCO/FEMA/MT (Divisão de Unidades de Conservação) bem como Federal, instituindo-se em 1994 o NUC/SUPES/MT (Núcleo de Unidades de Conservação) na Superintêndencia do Estado de Mato Grosso.

No ano de 1992 foram reservadas mediante Decreto do Governador do Estado, que declarou de interesse público 07 áreas, para fins de estudos, com 0 objetivo de implantar futuras Unidades de Conservação, a saber: Serra do Cachimbo (200.000 ha), Rio Madeirinha (500.000 ha), Pantanal do Rio das Mortes (500.000 ha), Cabeceiras do Rio Cuiabá (150.000 ha), Serra Ricardo Franco (150.000 ha), Serra de Santa Bárbara (300.000 ha) e Rio Ronuro, (400.000 ha) disponibilizando para estudos aproximadamente 2.200 ha.

A idéia do aproveitamento de uma Unidade já criada e não implementada no II PND foi encampada em 1992, pela FEMA/MT através da criação da Reserva Ecológia de Apiacá, localizada em área com pouca ocupação humana e ainda preservada, com área (100.000 ha) bastante reduzida em relação à primeira proposta de 1500.000 ha .

O Parque Estadual da Serra Azul, no Municipio de Barra do Garças, também foi produto de luta da sociedade organizada a ONG CELVA (Centro EtnoEcológico Vale do Araguaia) que desde 1990 já havia proposto a sua criação e a APA Pé da Serra Azul, ambas Unidades criadas em 1994.

Foi criada também a APA da Chapada dos Guimarães em 1995, com uma área bastante representativa $(251.847,93$ ha). envolvendo 04 municípios (Cuiabá, Chapada dos Guimarães, Campo Verde e Santo Antônio do Leverger). 
Em 1996, foram criadas a Reserva Extrativista Roosevelt Guariba e a Estrada- Parque Transpantaneira.

A Reserva Extrativista é ocupada por cerca de 60 familias (aproximadamente 400 pessoas), numa área restrita de 57.600 ha, remanescentes da época áurea da borracha, que sobrevivem da extração da borracha, castanha, farinha e óleo de copaíba. Mesmo sendo a área pequena, a Reserva representa uma certa segurança aos seus ocupantes.

A Estrada-Parque Transpantaneira possui apoio do Programa BID/Pantanal, que incentiva o turismo no pantanal tanto em Mato Grosso como em Mato Grosso do Sul, através de investimentos para a melhoria das estradas pantaneiras.

Os estudos de viabilização das sete áreas estão sendo realizados pela SPVS (Sociedade de Pesquisa em Vida Selvagem e Educação Ambiental), uma Organização Não Governamental, financiados através do Programa Prodeagro, contratada pela FEMA.

As Unidades Estaduais ainda não estão implantadas, sendo o Parque Estadual de Serra Azul, a Unidade de Conservação que terá sua infra- estrutura com inauguração prevista para fins de 97 , sendo considerada a Unidade de Conservação piloto da FEMA. 
$\overline{0}$

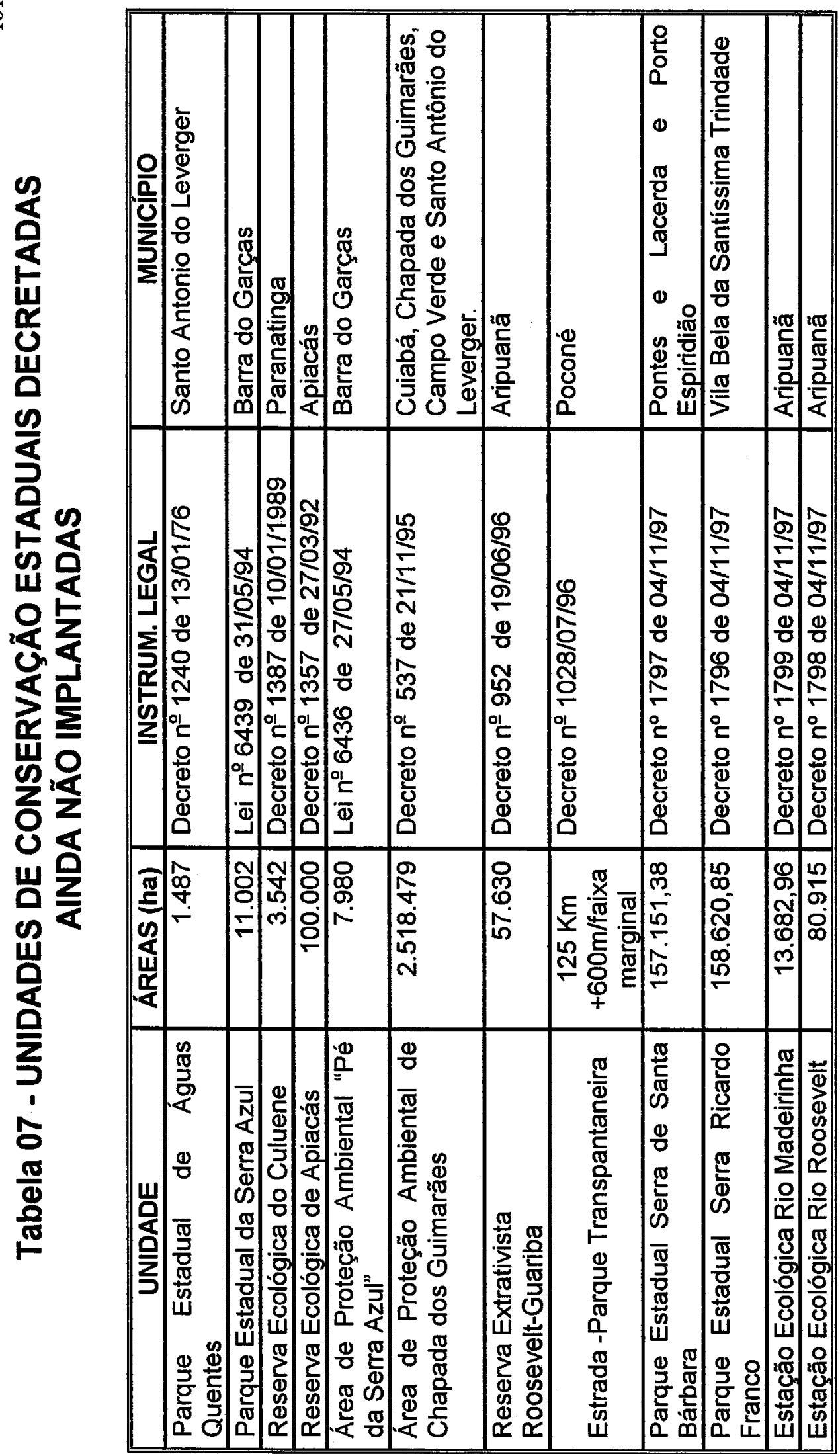




\section{V.9. Breves Considerações Acerca das Áreas Indígenas}

O Estado de Mato Grosso possui $11 \%$ de seu território decretado para as áreas indigenas, porém $60 \%$ delas ainda não foram demarcadas, o que significa que apenas 5.940 ha $(6,6 \%)$ estão efetivamente demarcadas. Comparando-se com 0,5\% (415.700 ha) de áreas decretadas para Unidades de Conservação, conclui-se que ambas ainda representam muito pouco do território mato-grossense.

Esses dados não podem ser analisados à sombra da contextualização dos fatos, pois os povos indígenas têm sido marginalizados dentro dos projetos nacionais de desenvolvimento econômico. Mesmo no atual contexto, as terras indígenas ainda continuam sendo vítimas de um processo de ocupação desordenado e predatório.

Segundo Seilert (1995) uma das chaves para a compreensão do movimento de participação marginal dos índios no processo de depredação dos recursos naturais de suas próprias terras é a transferência à terceiros do direito do usufruto das mesmas, ao tentarem se inserir no processo de desenvolvimento da região, ao serem excluídos das políticas públicas.

Citada por Seilert (1995) Heargraves relata fatos que ocorrem no grande Aripuanã "hoje os remédios, exames, carros, estradas, alimentação, combustivel, funcionários, motoristas, professores, atendentes, hospitais, etc são bancados com a venda de madeiras e outros recursos naturais", ressaltando-se que o mogno é adquirido dos índios a preços simbólicos que variam de U\$ 10 e U\$ 30 。 metro cúbico, cotado no mercado regional entre U\$250 a U\$ 350 e podendo atingir no mercado internacional até U\$1200

Mesmo sendo uma das principais atividades estipuladas dentro do PRODEAGRO a regularização fundiária de áreas indígenas e a fiscalização e vigilância para proteção das áreas e grupos indígenas, efetivamente pouco se fez. Sugere-se, para o enfrentamento da questão, a definição de uma política fundiária, agrícola, de saúde, educação e infra-estrutura, que respeite a especificidade cultural e ambiental dos povos indigenas bem como formas bem definidas de impedimento da

\footnotetext{
${ }^{7}$ Informação pessoal Paulo Nogueira Neto.
} 
exploração econômica dos recursos naturais desses povos por parte de frentes desordenadas e vorazes.

As áreas indígenas do Vale do Guaporé e Sararé se caracterizam pelo grande potencial de recursos florestais, minerais e rico acervo arqueológico (gravuras rupestres, cavernas e sítios arqueológicos), situadas onde originariamente a floresta contínua do Vale consistia em uma das maiores reservas naturais de mogno e cerejeira de todo o Estado de Mato Grosso. Atualmente estima-se que $80 \%$ do Vale do Guaporé já tenha sido desmatado, conservando-se apenas pequena parte, onde se encontram as áreas indigenas e que portanto são alvo de cobiça por parte do branco, do fazendeiro, do garimpeiro, do posseiro e do grileiro.

Nessa mesma região foram criados recentemente 02 Parques Estaduais, através do PRODEAGRO/FEMA, com a promessa de garantia de uma fiscalização realizada por um Comitê Interinstitucional de Fiscalização Ambiental Integrada e de Entorno de Áreas Indígenas (CIFA), pois mesmo a categoria de Áreas Indigenas não sendo considerada como Unidade de Conservação, por diferirem nas suas finalidades principais, podem funcionar articuladas.

O principal desafio indigenista do Estado ainda continua sendo a implementação de políticas capazes de retirar a comunidade indigena da marginalidade e inseri-la dentro de um modelo de desenvolvimento sustentado. 


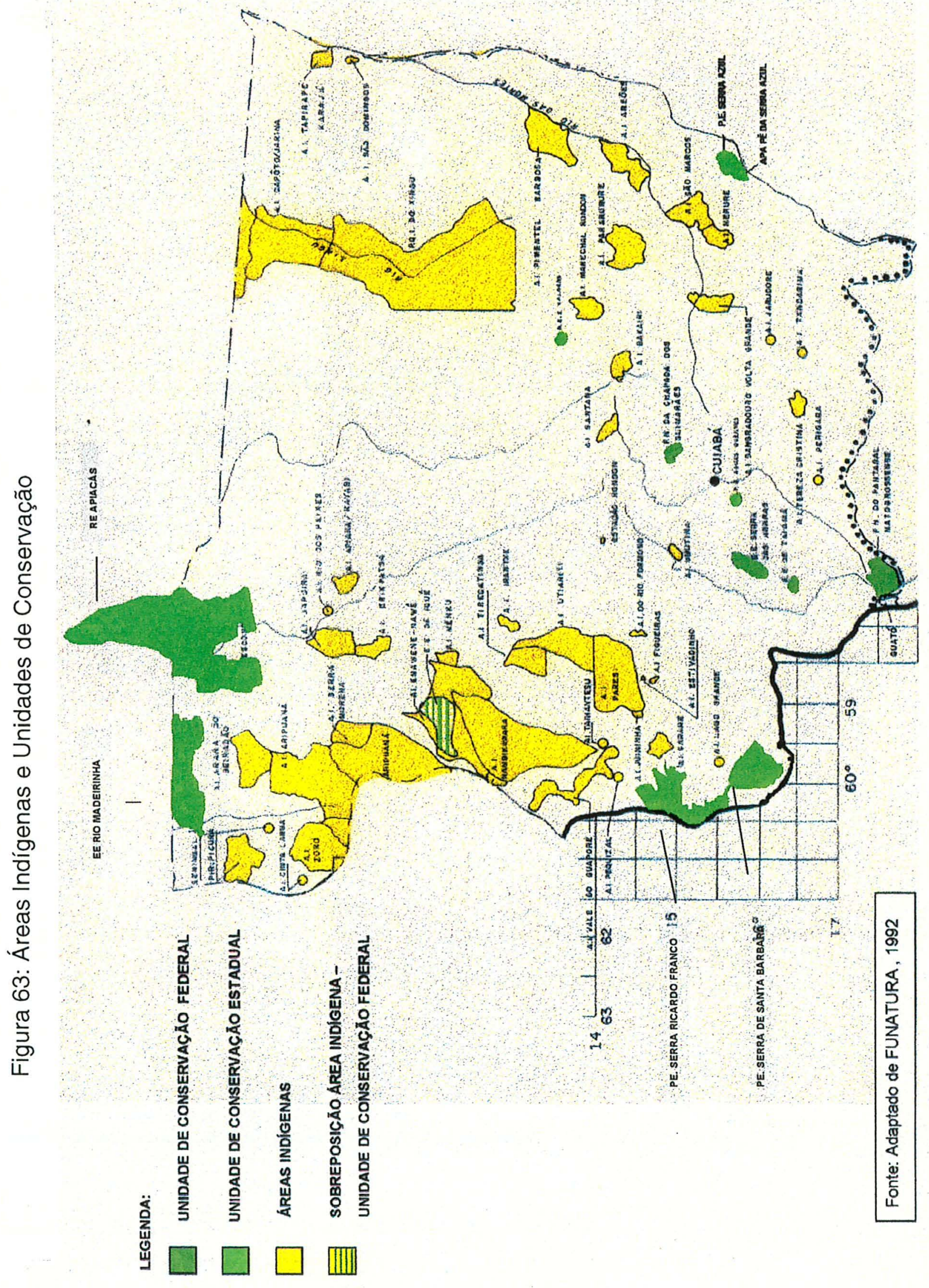




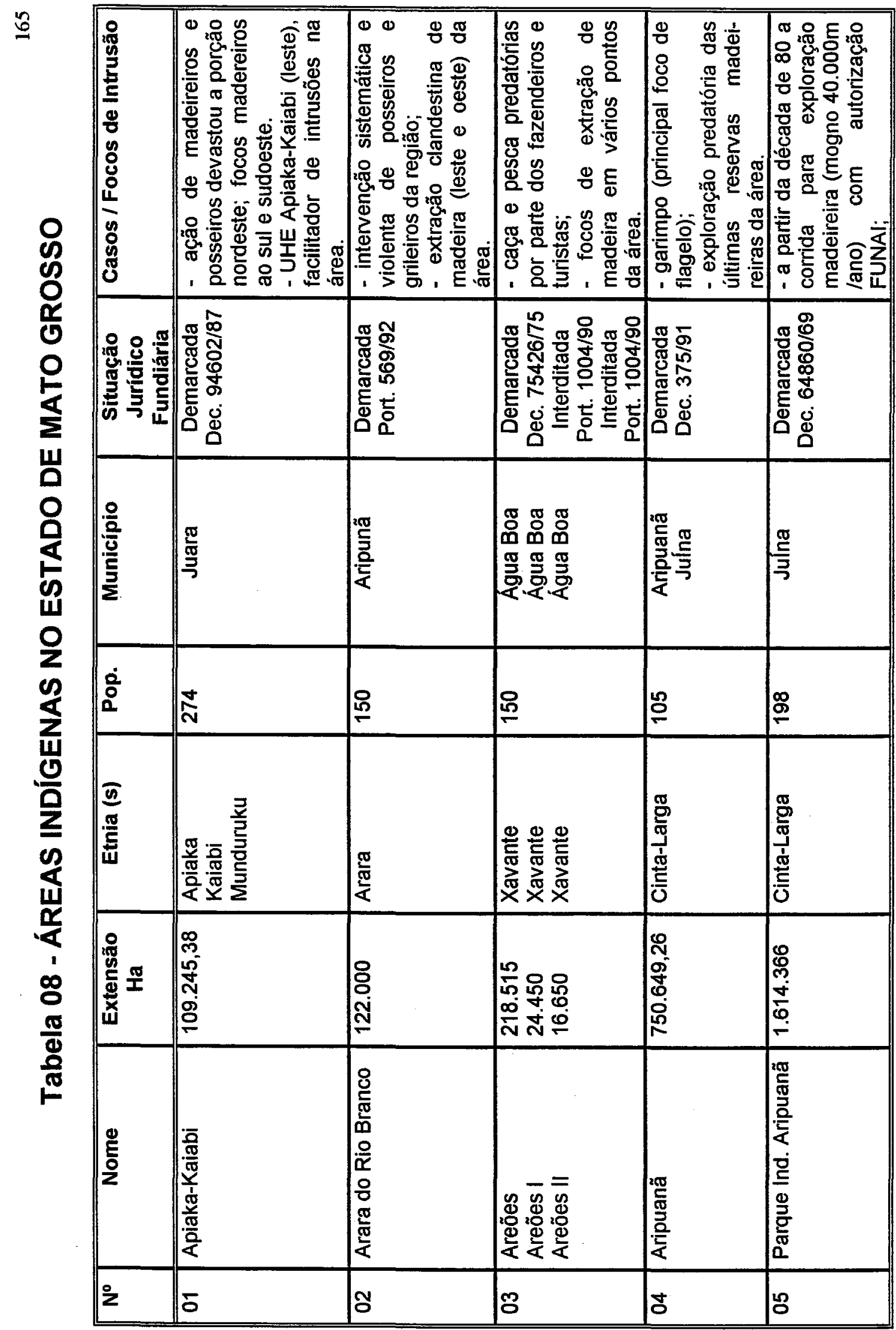

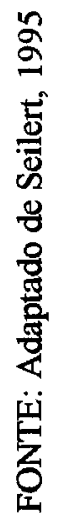




\begin{tabular}{|c|c|c|c|c|c|c|}
\hline & & & & 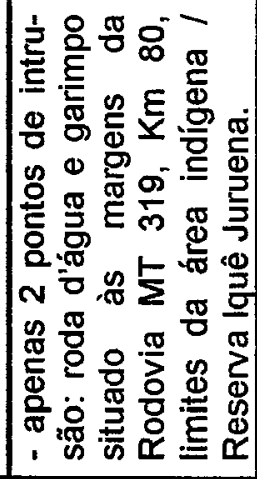 & 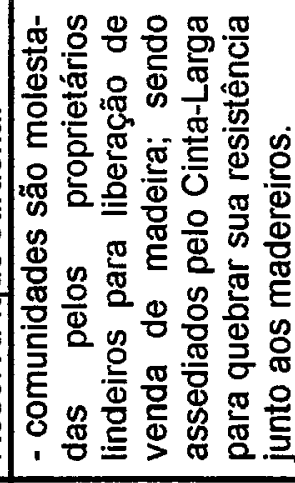 & 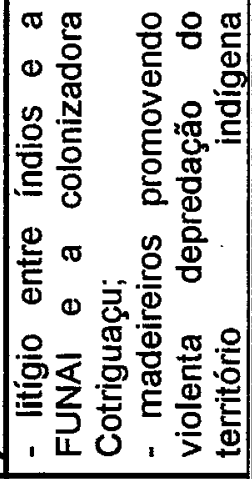 \\
\hline & 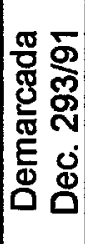 & 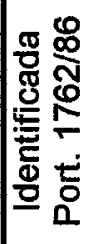 & 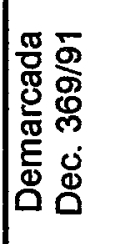 & 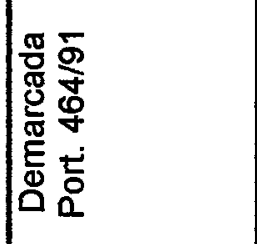 & 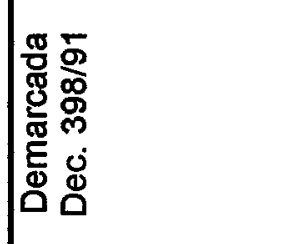 & 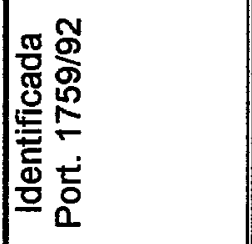 \\
\hline & 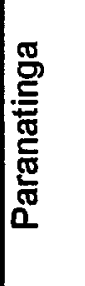 & 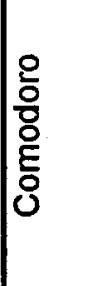 & 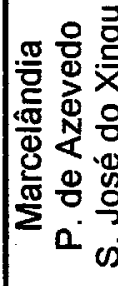 & 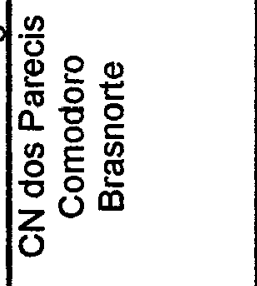 & 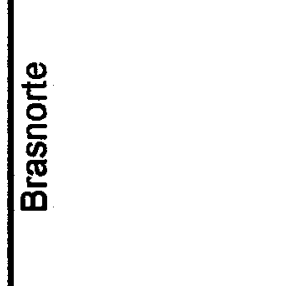 & 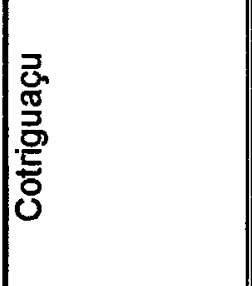 \\
\hline & \& & $\stackrel{\sim}{\sim}$ & 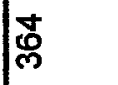 & ষ্ল & ஜ: & if \\
\hline & 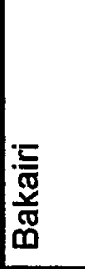 & 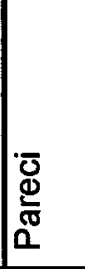 & 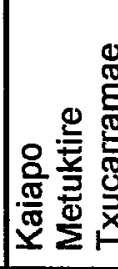 & 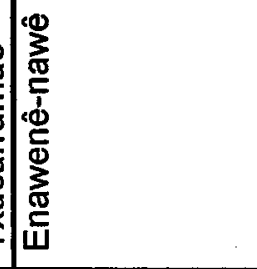 & 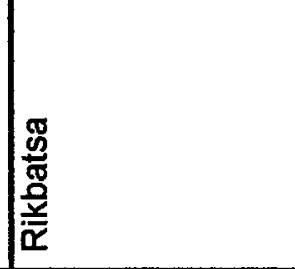 & 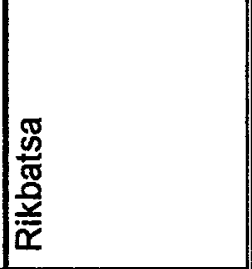 \\
\hline & 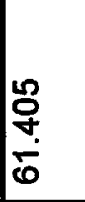 & 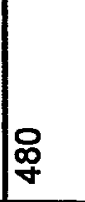 & 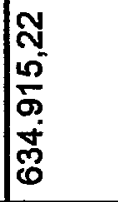 & 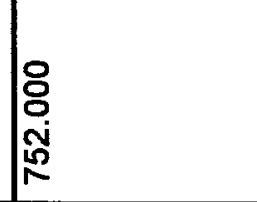 & 㞧 & $\frac{O}{\frac{9}{0}}$ \\
\hline & 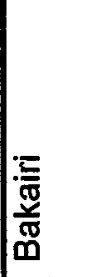 & 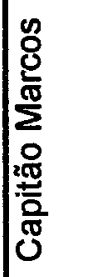 & 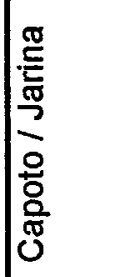 & 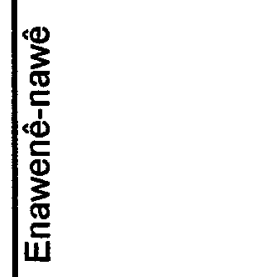 & 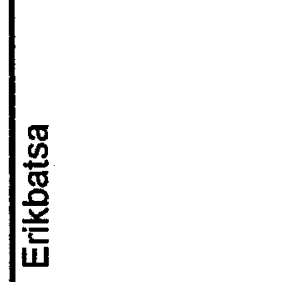 & 음 \\
\hline 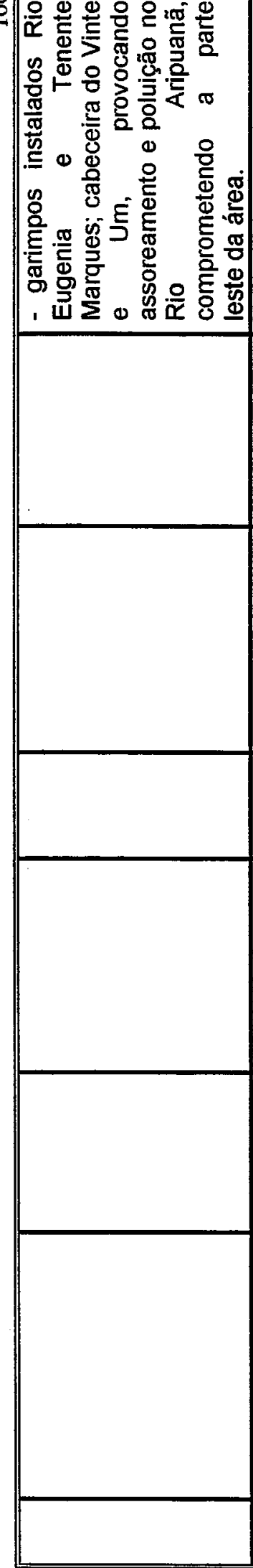 & 8 & Is & 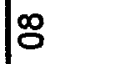 & 8 & 은 & $F$ \\
\hline
\end{tabular}




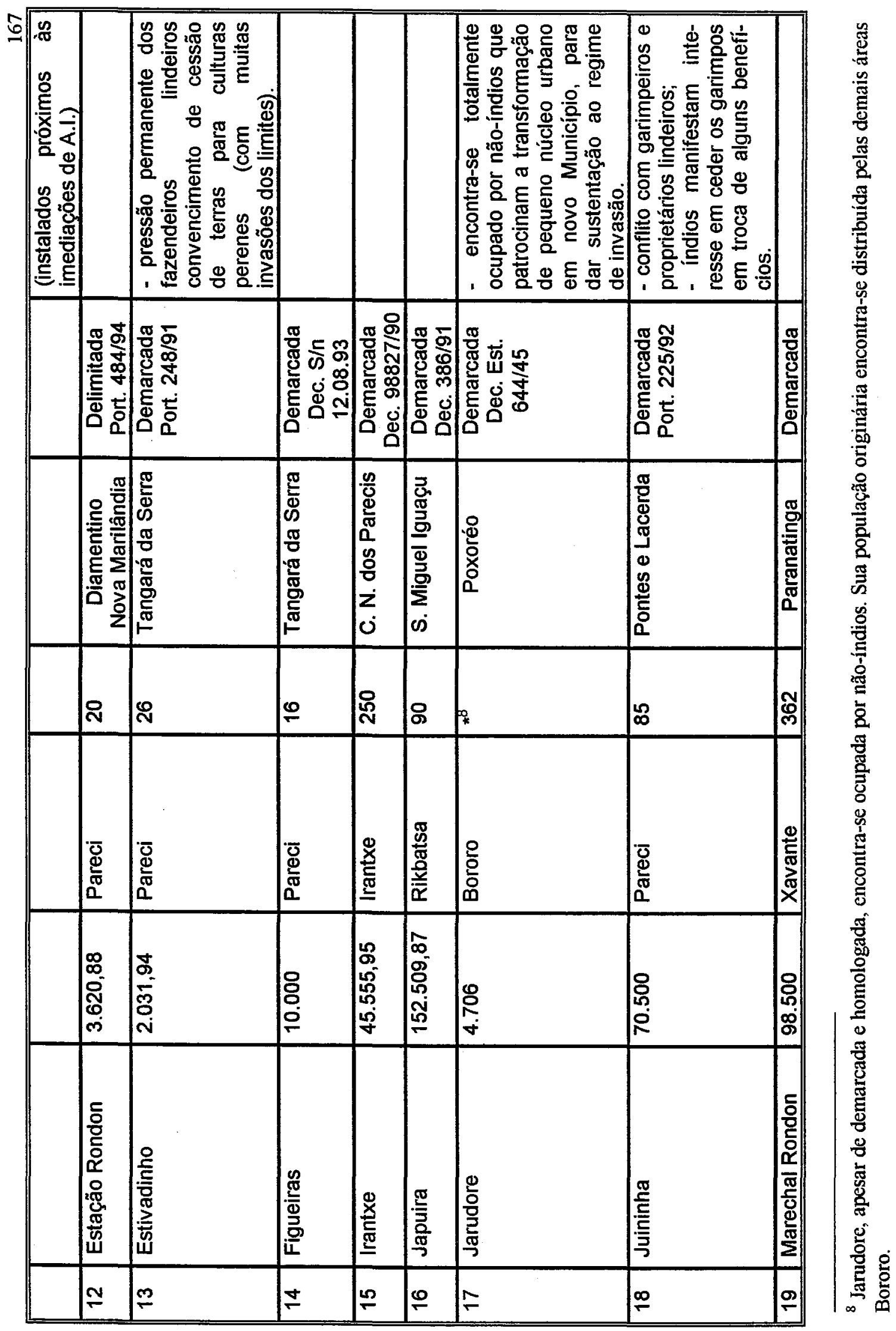




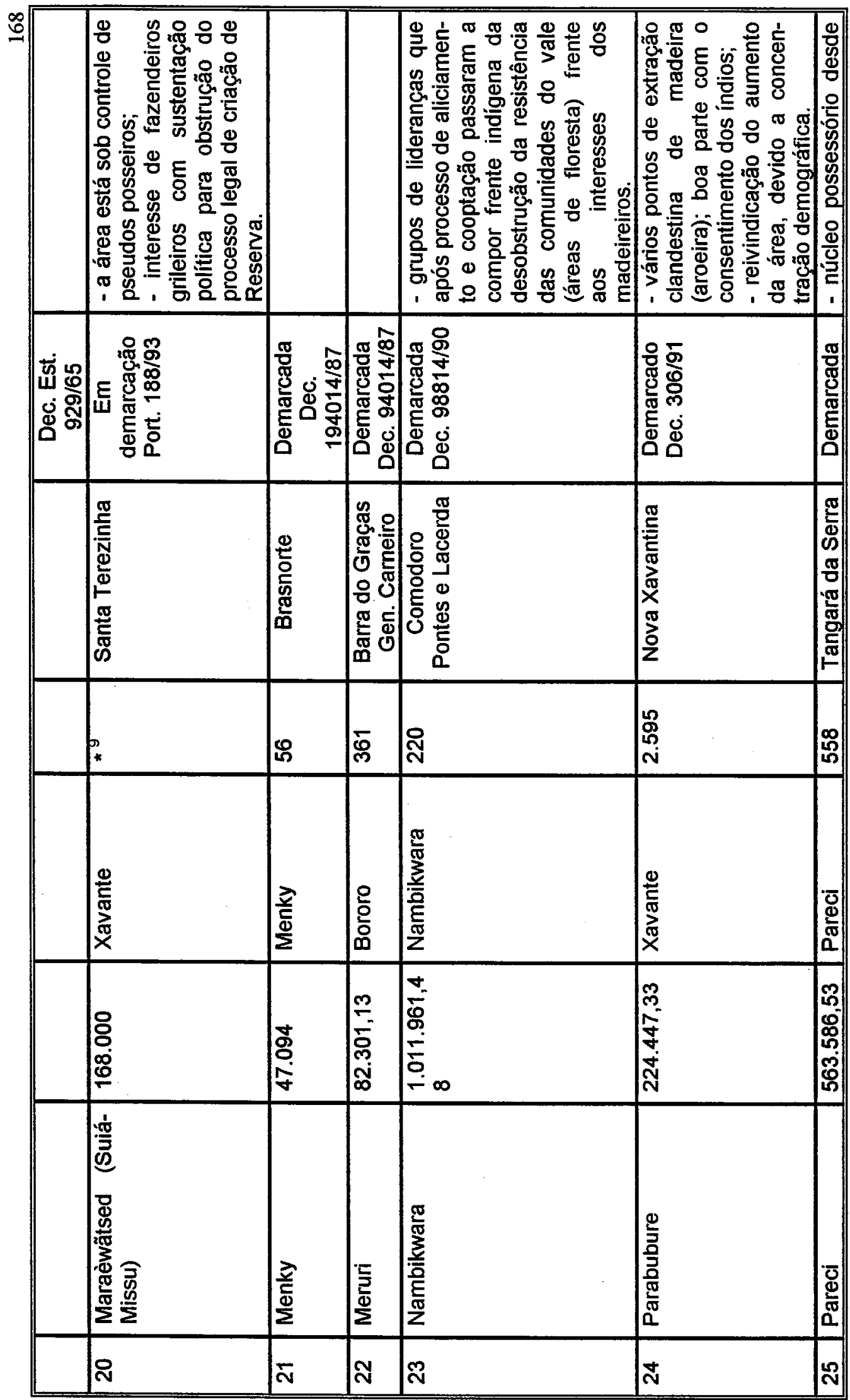

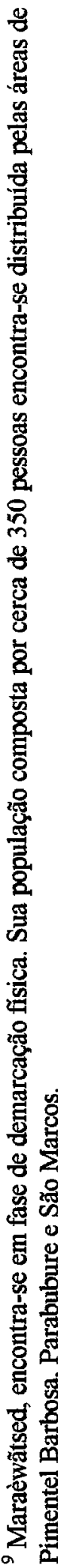




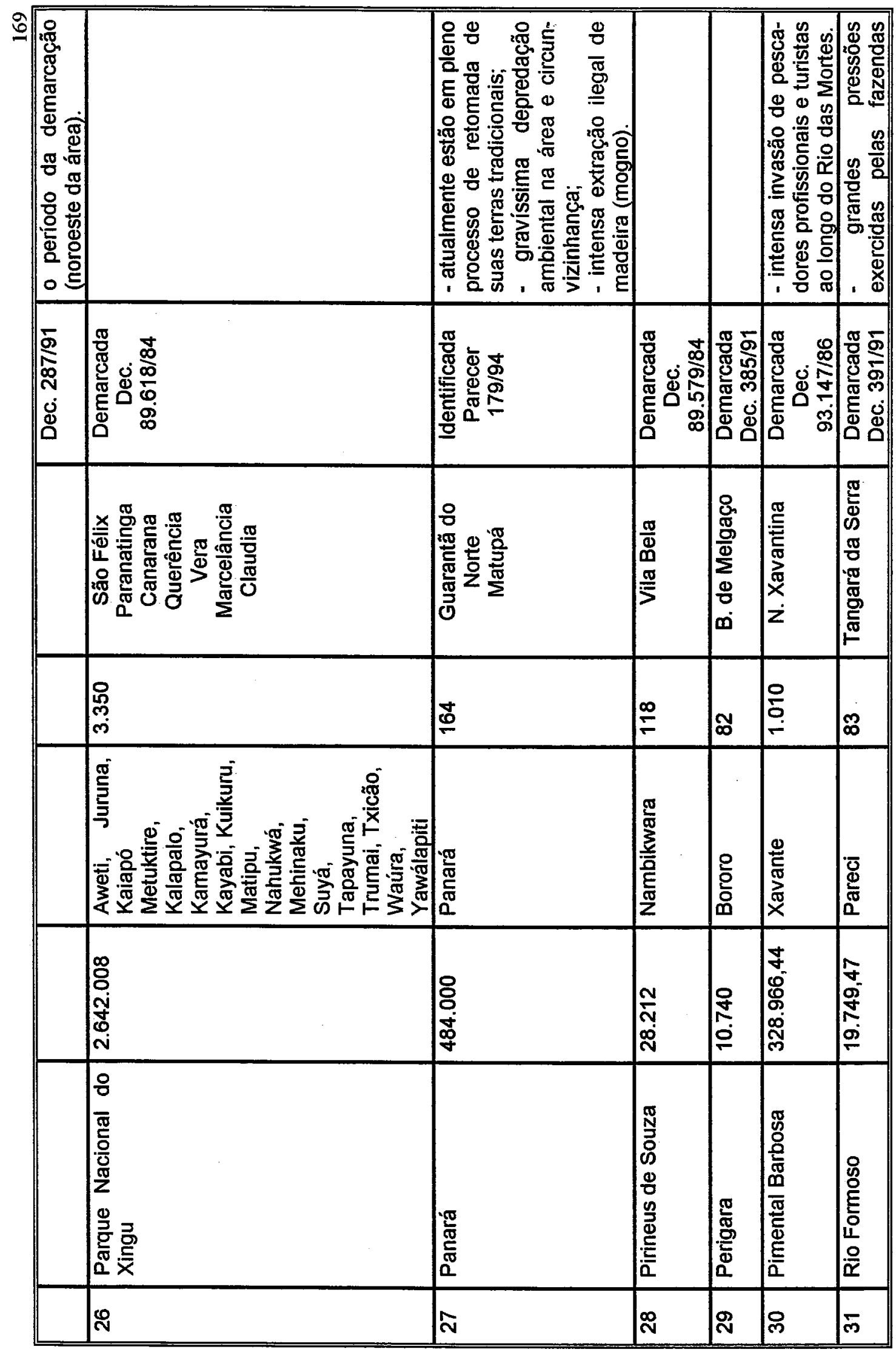




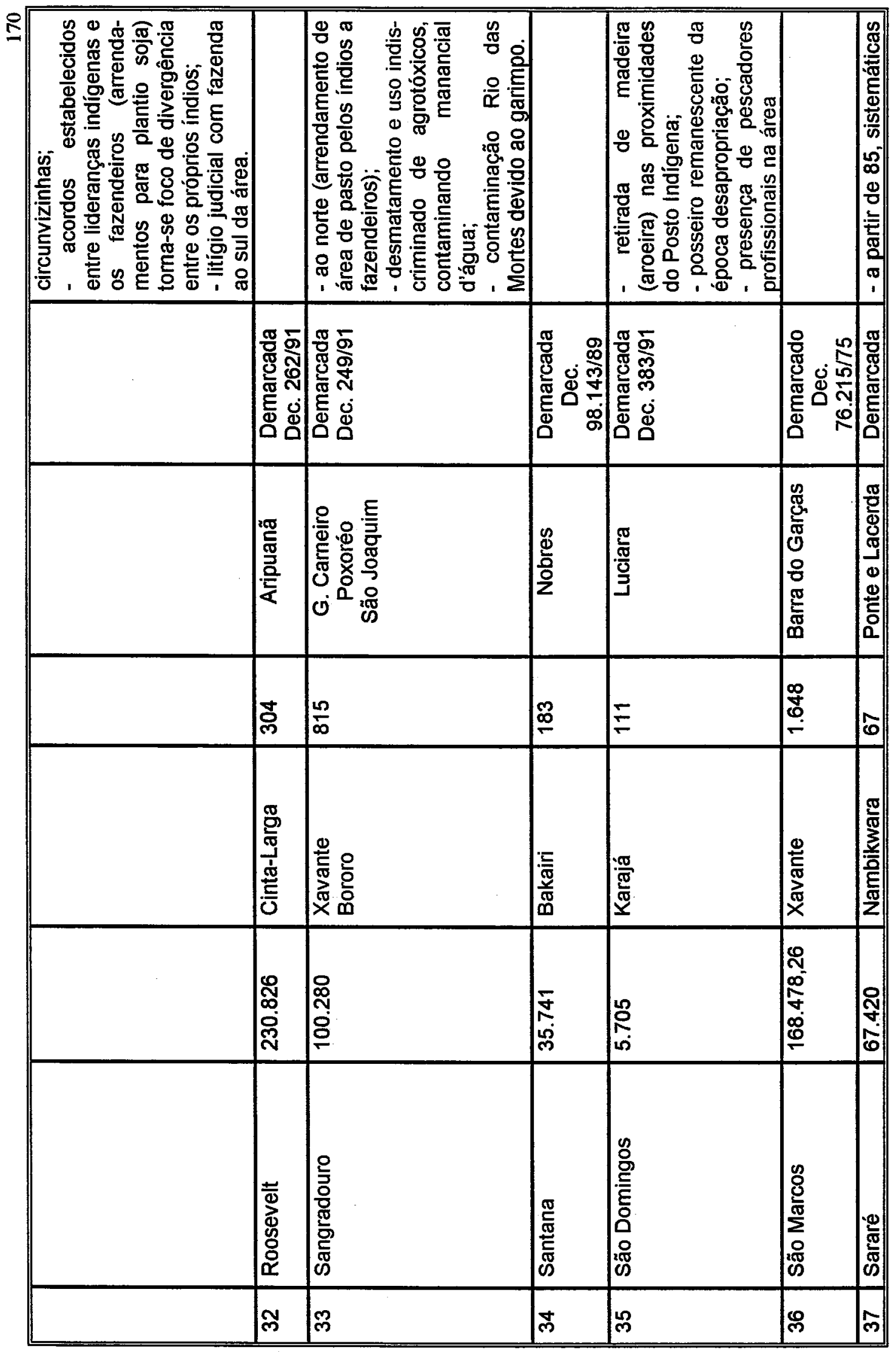




\begin{tabular}{|c|c|c|c|c|c|}
\hline 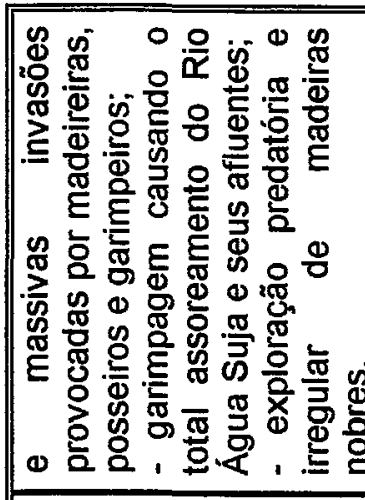 & 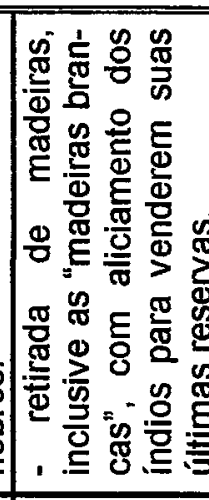 & 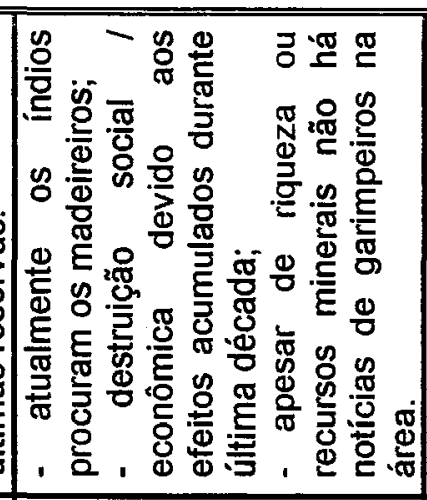 & & 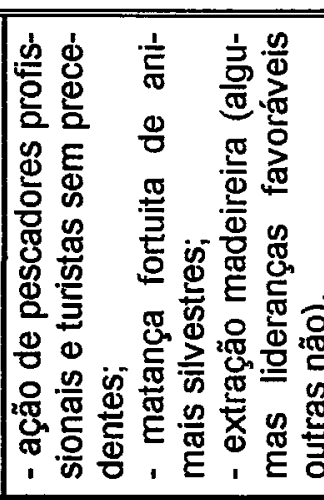 & 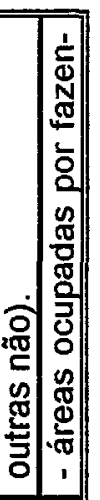 \\
\hline 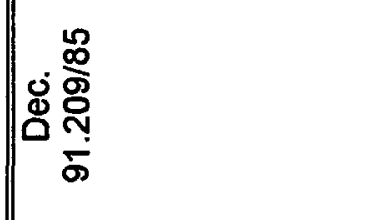 & 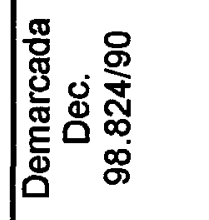 & 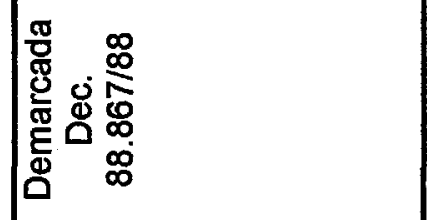 & 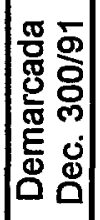 & 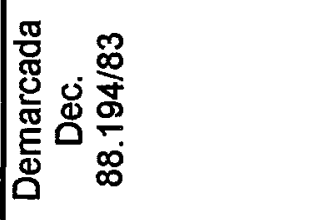 & $\mid$ \\
\hline \multirow[t]{6}{*}{ 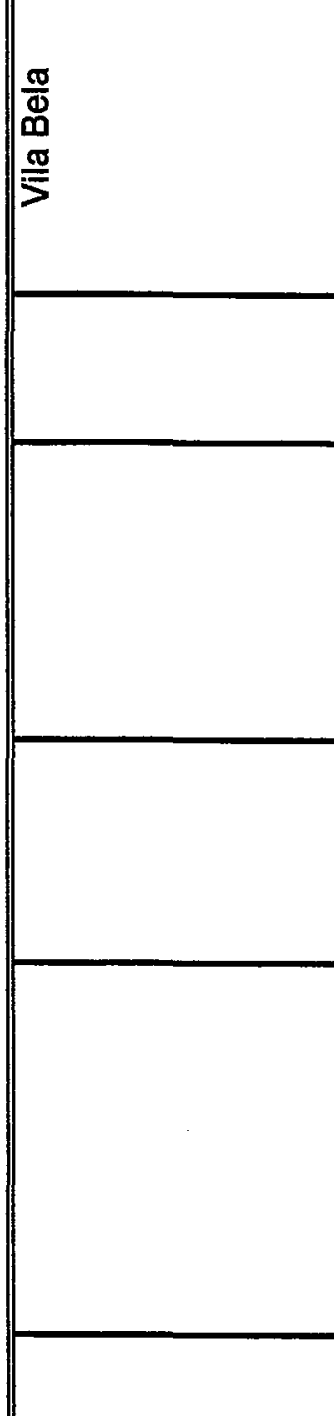 } & 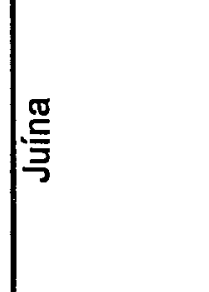 & 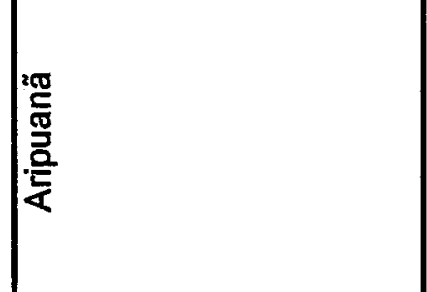 & 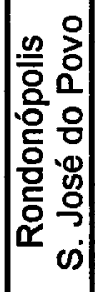 & 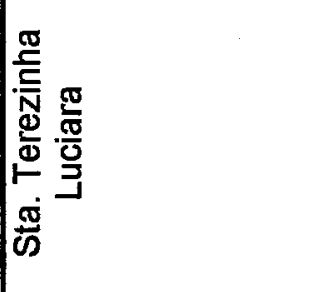 & 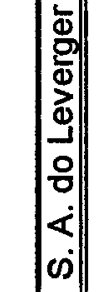 \\
\hline & is & 怘 & פ్ & if & (o) \\
\hline & 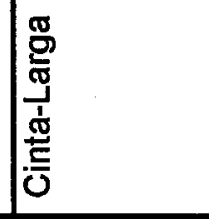 & 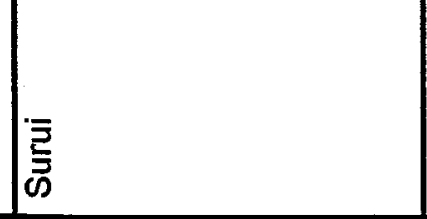 & 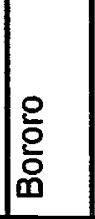 & 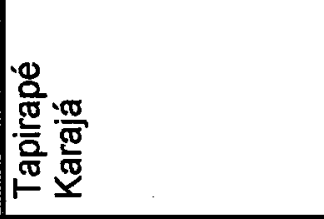 & $\mid$\begin{tabular}{|c|}
0 \\
$\vdots$ \\
$\vdots$ \\
$\vdots$
\end{tabular} \\
\hline & 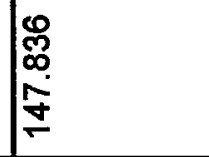 & 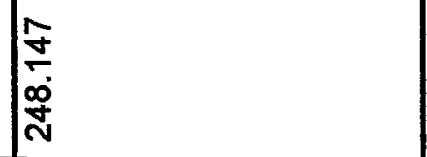 & 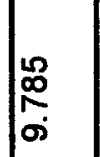 & 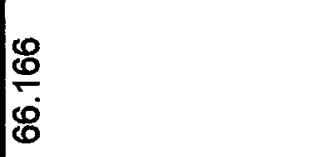 & 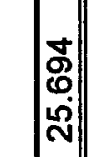 \\
\hline & 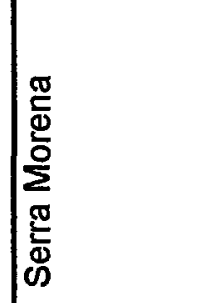 & 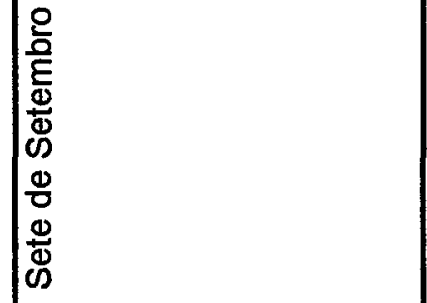 & 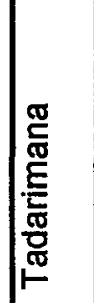 & $\mid$ & $\mid$ \\
\hline & $\infty$ & \% & I & $\mp$ & ₹ \\
\hline
\end{tabular}




\begin{tabular}{|c|c|c|c|c|c|c|}
\hline 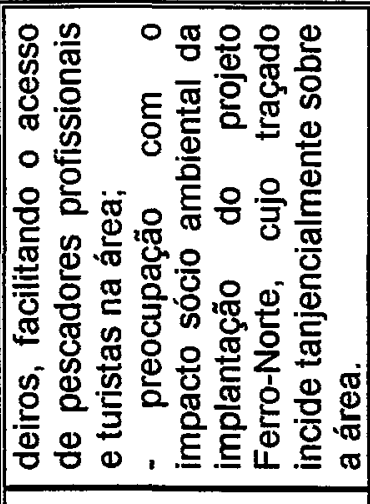 & & & & & 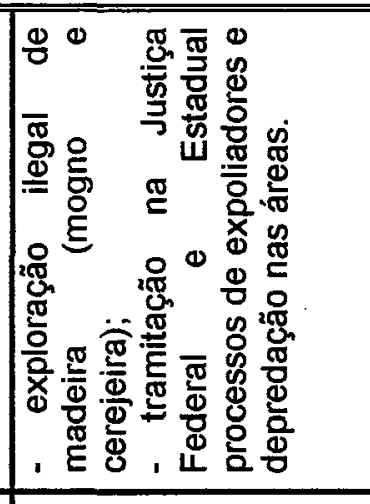 & 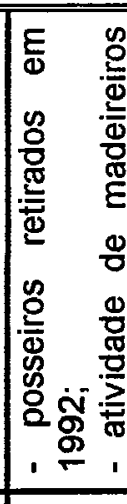 \\
\hline \multirow[t]{7}{*}{ 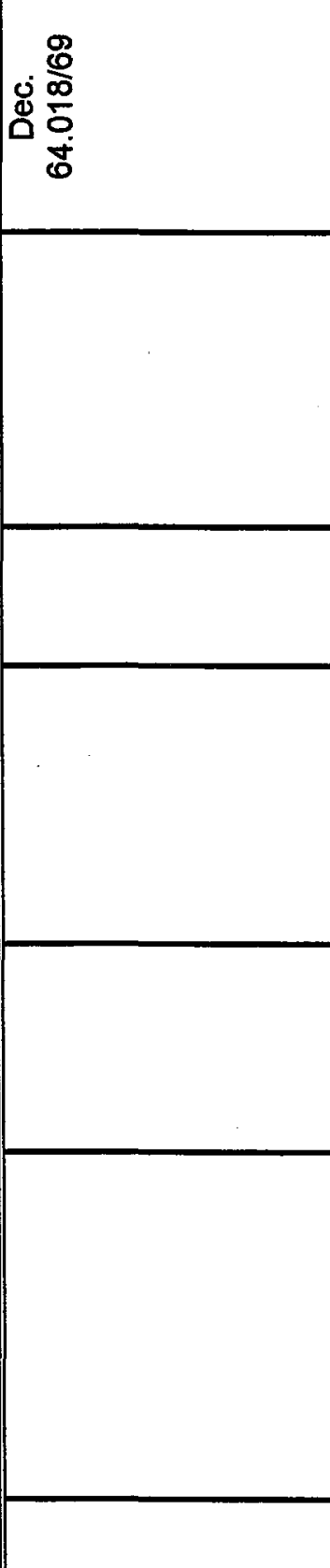 } & 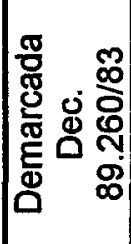 & 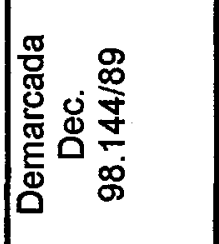 & 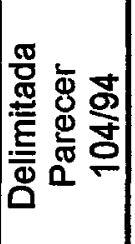 & 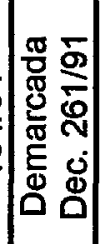 & 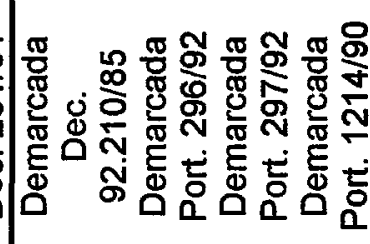 & 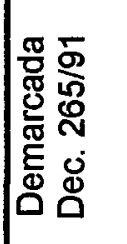 \\
\hline & 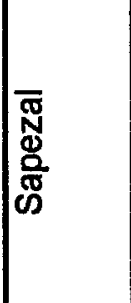 & 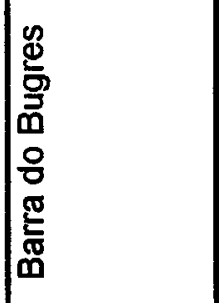 & 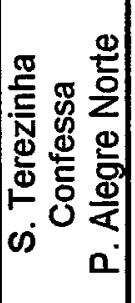 & 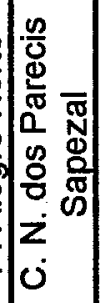 & 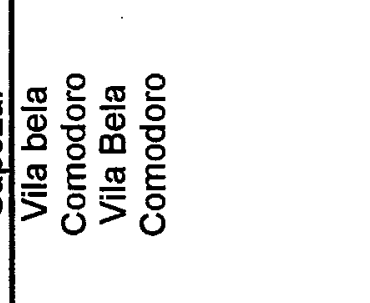 & 登 \\
\hline & $\bar{\sigma}$ & 品 & & 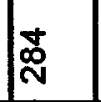 & $\frac{1}{8}$ & 跑 \\
\hline & 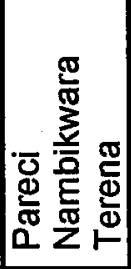 & 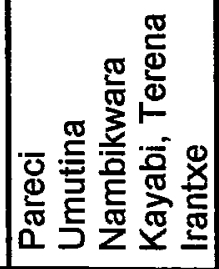 & 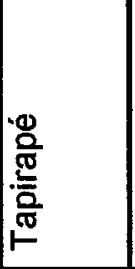 & 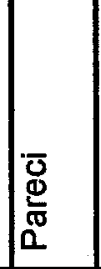 & 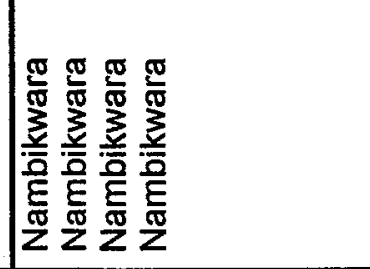 & 음 \\
\hline & 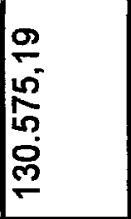 & 旅 & 总 & 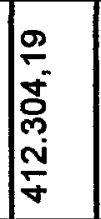 & 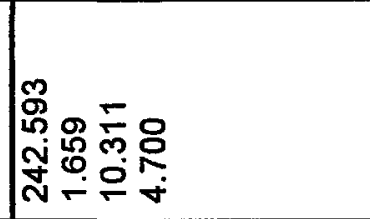 & 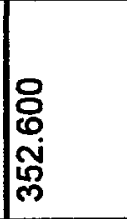 \\
\hline & 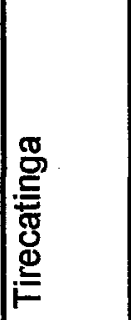 & 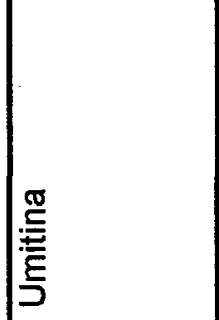 & 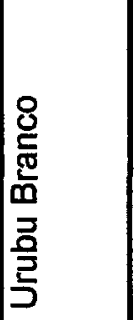 & 吾 & 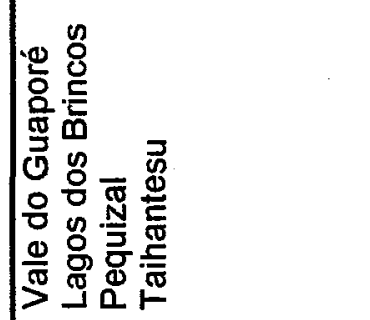 & 음 \\
\hline & m & \& & 呫 & $\mathscr{q}$ & 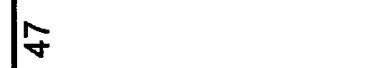 & 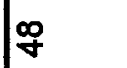 \\
\hline
\end{tabular}




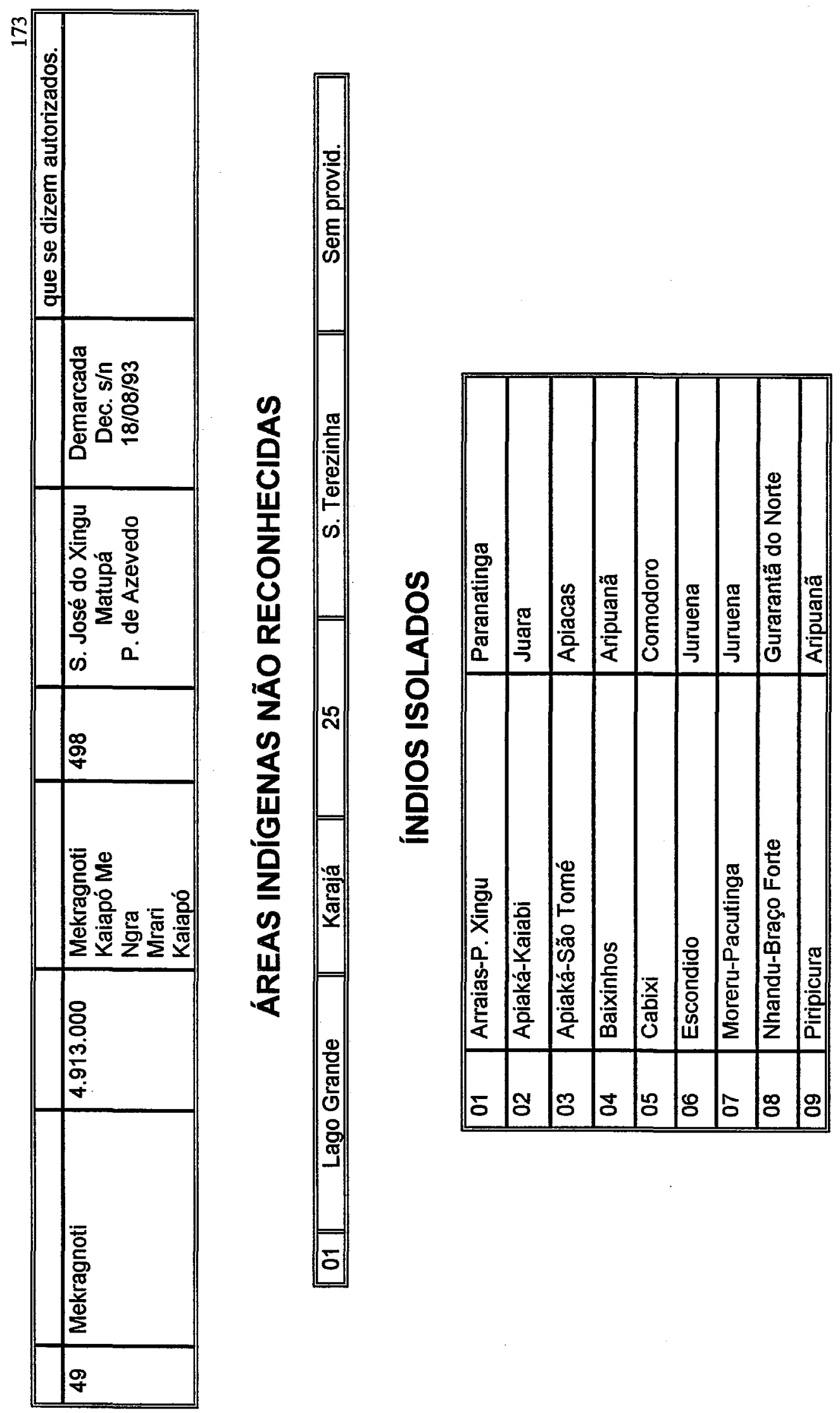




\section{DISCUSSÃO}

\subsection{Situação Histórica e Geográfica das Unidades de Conservação}

O resgate histórico das Unidades de Conservação do Estado de Mato Grosso foi difícil e trabalhoso, pois os dados estão bastante dispersos e poucos dados existem junto aos Órgãos gestores, como no IBAMA no caso das Unidades Federais e no caso das Unidades Estaduais os dados não estão disponibilizados junto à FEMA, aguardando o término dos estudos de viabilização da maioria das Unidades, que estão sendo realizados por empresas terceirizadas pelo Órgão Estadual.

A grande maioria das Unidades de Conservação Federais estão situadas a noroeste e sudeste do Estado. E conforme os levantamentos de seus processos históricos e antecedentes legais fica demonstrado que foram criadas em áreas que não se prestaram à utilização pelas frentes agropecuárias, escapando ao rápido processo de ocupação da região amazônica.

Os fragmentos devem ser vistos como o resultado de um processo histórico de perturbação da vegetação, no qual inúmeros fatores interagiram ao longo do tempo. Para se entender a estrutura e dinâmica atuais de um determinado fragmento é importante reconstruir ao máximo a história da vegetação local (Viana, 1990).

Para tal, trabalhou-se o item Histórico de Ocupação da Região, com o objetivo de se observar as diferentes histórias de perturbação em cada região de inserção da Unidade de Conservação abordada.

Toledo (1993), estudando duas áreas na Mata Atlântica que apresentavam características de tamanho, forma e vizinhança similares, verificou que elas diferiram apenas na história de perturbação e na estrutura da floresta, o que influenciou na demografia de espécies da avifauna.

A efetividade de cada Unidade de Conservação depende muito de seu tamanho, já que áreas pequenas não conseguem manter populações viáveis com baixa densidade. O desaparecimento dessas espécies causa efeito cascata no 
ambiente protegido, aumentando ou reduzindo a densidade de outras espécies e sua probabilidade de sobrevivência (Dias, 1993).

Para a conservação da biodiversidade nos trópicos, segundo alguns especialistas (Terborgh, 1974; Diamond, 1975) seria necessária a implantação de Unidades de Conservação com grandes extensões, em torno de 260.000 ha, ou mesmo segundo recomendação da FUNATURA, 500.000 ha, para que a redução do índice de extinção possa ter níveis aceitáveis de menos de $1 \%$ ao século.

A relação entre área e diversidade originou a controvérsia no campo do planejamento e manejo de reservas, não existindo uma resposta universal para a questão, entretanto a discussão sobre tamanho ideal de reservas não deve parar somente na análise de diversidade biológica. $O$ tamanho de um fragmento afeta tanto a dinâmica das populações vegetais como animais.

Toledo (1993), sugere que estudos voltados para tamanho mínimo de reservas, devam levar em consideração o tamanho das populações e não apenas a riqueza específica da área, para não correr-se o risco de avaliar uma riqueza temporariamente curta.

Os efeitos da forma dos fragmentos sobre a diversidade biológica e sustentabilidade da floresta, podem ser tão marcantes como os do tamanho da área.

Quando da fragmentação, ocorrem mudanças imediatas e pronunciadas, iniciando-se pelas mudanças na luminosidade, temperatura, umidade e velocidade dos ventos, sendo mais pronunciadas na borda. Estudos realizados com fragmentos no interior de São Paulo de floresta de planalto, demonstraram que 0 efeito de borda foi especialmente mais pronunciado nos fragmentos de menor tamanho (Viana, 1990).

Para uma mesma forma, a fração do fragmento sujeita ao efeito de borda é inversamente proporcional ao tamanho do fragmento (Viana, 1990).

As Unidades de Conservação estudadas apresentam as seguintes formas e áreas representadas na figura 64. 


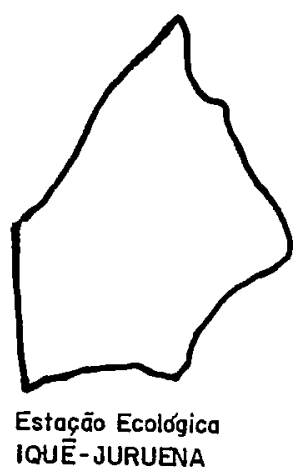

200.000 ha

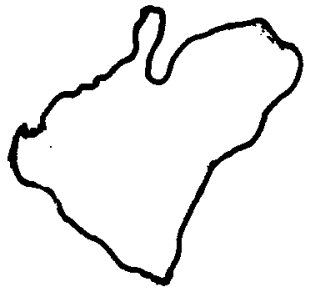

Parque Nacional do PANTANAL MATOGROSSENSE

138.000 ha

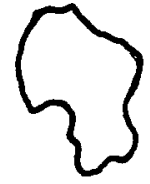

PARNA de C. DOS GUIMARĀES

33.000 ha

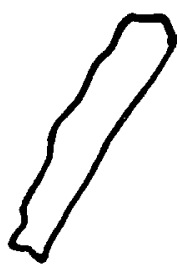

E. E. SERRA DAS ARARAS

28.700 ha

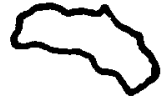

E. E. TAIAMĀ

16.000 ha

Fonte: $F C R-M T$

Figura 64 - Formas e Áreas das Unidades de Conservação Federais do Estado de MT.

Segundo recomendações do documento Estratégia Mundial para Conservação, geralmente uma grande reserva é melhor do que uma pequena. As dimensões e distribuição a que se deve dar preferência estão representadas na figura 65 a seguir, onde princípios geométricos são procedentes de estudos biogeográficos insulares, propostos para o projeto de reservas naturais. Em cada um dos espaços designados por letras de $\mathrm{A}$ a $\mathrm{F}$, as taxas de extinção das espécies serão menores em relação aos esquemas da reserva abaixo (Diamond, 1975).

MELHOR

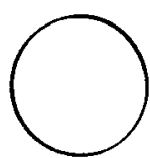

A

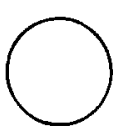

B

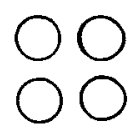

C

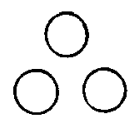

D

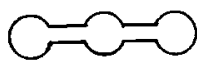

E

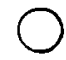

$\mathbf{F}$

PIOR

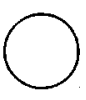

A

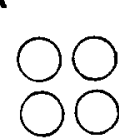

$B$

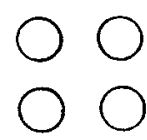

c

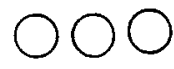

D

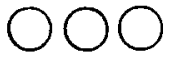

E

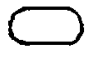

$\mathbf{F}$

Figura 65 - Dimensões e distribuições de reservas recomendadas

As Unidades de Conservação do Estado foram criadas mediante decisão do poder Público, à exceção do Parque Nacional da Chapada dos Guimarães e do Parque Estadual Serra Azul, que foram criadas por iniciativa de intensa participação de representantes de ONG's e pessoas engajadas com a conservação na região. 


\subsection{Características Sócio-Econômicas e Culturais}

\subsubsection{Diagnóstico Geral de Regularização das Unidades}

Conforme o que foi estabelecido no Decreto-Lei $n^{\circ} 9.760 / 46$, as Unidades de Conservação são áreas que dependem de iniciativas de regularização, além de ações de desapropriação, mesmo que tenham sido criadas em terras públicas.

Conforme os dados do Workshop "Políticas de Unidades de Conservação" (1994) tanto o Parque Nacional da Chapada dos Guimarães (12/04/94) quanto a Estação Ecológica Serra das Araras (31/05/87) e a Estação Ecológica Taiamã (02/06/86) estão com os seus respectivos prazos de Decretos de desapropriação expirados nas datas citadas e se a interpretação estiver correta, significa que as Unidades de Conservação citadas não possuem a devida cobertura legal sobre as terras privadas remanescentes do processo de aquisição.

A área de 33.000 ha do Parque Nacional da Chapada dos Guimarães é considerada insuficiente, pois representa apenas um terço do que deveria ter sido protegido, segundo o documento da ARCA (1989) "Críticas à Delimitação do Parque Nacional da Chapada dos Guimarães" que reinvidicava 100.000 ha, cuja diminuição drástica da área foi atribuída à forte especulação imobiliária na região. $O$ governo federal adquiriu somente $0,62 \%$ da área. A Estação Ecológica Serra das Araras possui $98,95 \%$ das terras adquiridas, restando algumas áreas a serem regularizadas, sendo que nessas áreas os proprietários continuam com o direito da fazer uso de suas terras, que são destinadas para pecuária e agricultura, mesmo dentro das áreas protegidas, o que é incompativel com os objetivos desses tipos de Unidades de Conservação.

O orçamento da área ambiental está comprometido em grande parte com programas financiados por empréstimos de Bancos multilaterais (BIRD, BID) e agências de cooperação internacional, que não contemplam um programa para a aquisição de terras, ficando na total dependência de previsão de custos estabelecidos e incluidos na previsão do Orçamento do Governo Federal, que não acena com nenhum recurso em 1997 para regularização fundiária. 


\subsubsection{Questão de sobreposição de UC em terras indígenas}

Dentre as Unidades mato-grossenses somente a Estação Ecológica lquê-Juruena possui sobreposição em área indigena, valendo a pena ressaltar que justamente esse fato é o que garante a defesa da área, devido a distribuição de placas da FUNAI, ao longo da área da Estação, limítrofe à rodovia AR-1.

Esse conflito foi resolvido anteriormente através do termo 001/88, onde ficou acordada a perambulação dos índios Enaunê-Nauwê na área da Estação Ecológica

Através do Decreto de 02/10/96, o presidente da República, homologou a demarcação administrativa provinda da Fundação Nacional do Índio-FUNAl, da terra indígena (752.000 ha contando com a área da Estação), destinada à posse permanente do grupo indígena Enawenê-Nawê, e no seu artigo segundo, revogou o item III do Decreto no 86 061, de 02/06/81, que criou a Estação Ecológica lquêJuruena.

Esse ato possivelmente foi fruto de uma falha administrativa, e caso não seja revogado, o Estado de Mato Grosso perde sua maior Unidade de Conservação com localização entre o contato da floresta amazônica e o cerrado.

\subsubsection{Aspectos culturais}

Em todas as regiões em que estão inseridas as Unidades de Conservação Mato-grossenses, encontram-se a presença ou de fósseis e lou de inscrições sobre rochas ou cavernas, que estão sob a proteção em Unidades de Conservação, através do Decreto n 99556 de 01/10/90, que dispõe sobre a proteção das cavidades naturais subterrâneas existentes no território nacional (Pinto, 1996)

É necessário que se conscientize a população, da importância desses "achados" no caso de fósseis, que ocorrem principalmente em zona garimpeira, nos entornos das Unidades. Que esse tipo de material possui alto valor científico e que os técnicos especializados devem ser chamados para o estudo "in loco", o que não impediria o trabalho nos garimpos 


\subsubsection{Zona de entorno}

A rigor, a área afetada pela implantação da Unidade de Conservação é bem mais ampla e abrangente do que a faixa de $10 \mathrm{~km}$, citada na Resolução $\mathrm{n}^{\circ} 13$ de 06/02/90 do CONAMA. Toda a população da região onde está implantada uma Unidade de Conservação torna-se parte integrante do processo, quer pelo interesse conservacionista, quer pela interferência causada em sua vida, principalmente no que diz respeito à limitação do uso de recursos naturais.

A grande ênfase dada aos trabalhos no entorno das Unidades de Conservação é uma forma de evitar a passagem brusca entre a área protegida e as áreas lindeiras.

O Parque Nacional da Chapada dos Guimarães é identificado como sendo a Unidade de Conservação Mato-grossense com maiores problemas, tanto no seu interior como no seu entorno, ou como dizem os representates da ARCA é o Parque em que mais existem denúncias por parte da ONG. E a exemplo do Parque Nacional de Brasilia, é praticamente um parque urbano, devido a sua proximidade com a capital Cuiabá.

Os processos de desenvolvimento e crescimento, geram efeitos diretos e indiretos em seu ecossistema, sendo o mais danoso o isolamento ecológico (Dasmann, 1983).

A artificialização do entorno, além de outros problemas como o fundiário, trazem preocupação tanto de ordem administrativa quanto jurídica, assunto que tem gerado grande polêmica, resultando em ações desde 1995, junto ao Ministério Público, com o intuito de impedir o desmatamento do entorno do Parque. Através dessa ação a ARCA espera que sejam definidas as atividades que podem afetar a biota da Unidade de Conservação, conforme o que está estipulado no Artigo $1^{0}$ da Resolução 013/90, ou seja a criação de um dispositivo legal, pois ficando em aberto dificulta o disciplinamento dessas atividades. O que seria bastante importante para o Órgão gestor que se vê pressionado pela grande especulação imobiliária que envolve o Parque Nacional.

Criada em 1995, a APA de Chapada dos Guimarães, envolve não só a Chapada dos Guimarães como Cuiabá, sob gestão do Órgão ambiental do Estado 
FEMA, mas que apesar dos esforços, os atos de destruição parecem se intensificar na região.

No Parque Nacional do Pantanal Mato-Grossense existem grandes áreas alagáveis e como o entorno é o grande refúgio da sua fauna o problema foi resolvido com a aquisição pela ONG Ecotrópica, de duas fazendas lindeiras ao Parque que foram transformadas em RPPN em 1997, com uma área aproximada de 52.818 ha abrangendo áreas de Mato Grosso e Mato Grosso do Sul.

Atualmente tanto a Ecotrópica como o IBAMA, através da SUPES/MT, têm realizado uma gestão compartilhada para que unindo toda essa área, possa ser realizado um único Plano de Manejo, projeto esse fruto de estudos anteriores.

Outra questão polêmica é a Hidrovia Paraguai-Paraná (sistema de navegação de 3440 kilômetros que ligará o Município de Cáceres (MT) até Nueva Palmira no Uruguai, sendo que o trecho mais polêmico da futura obra está justamente nos $600 \mathrm{~km}$ que atravessam o Pantanal. Nessa região estão localizadas as seguintes Unidades de Conservação: Estação Ecológica Taiamã (Cáceres), Parque Nacional Pantanal Matogrossense (Poconé) e as Reservas Particulares do Patrimônio Natural Dorochê (Poconé), Acurizal e Penha (Corumbá), onde existem entre outros atributos, cerca desete sítios arqueológicos ainda pouco conhecidos. Além da Reserva Indígena Guató na llha da Ínsua, à beira do Rio Paraguai. A hidrovia teve seu pedido de embargo através de uma Ação Pública na Justiça Federal, tendo como alegação a falta de consulta junto à Reserva indígena. Sendo que até hoje também não houve discussão acerca das Unidades citadas que serão afetadas diretamente, pois é nesse trecho do Rio Paraguai, que estão previstas as obras de dragagem e remoção de rochas e correção de curvas do referido rio.

\subsubsection{Aspectos Sócio-Econômicos e Culturais}

As informações contidas no tópico se referem à realidade sócioeconômica do Município onde está inserida a Unidade de Conservação e também Municípios que possuem influência direta sobre as mesmas.

Os dados disponiveis não se prestam "per si", para uma análise mais profunda, no entanto, é possivel tecer considerações que poderão servir de base para 
estudos "in loco" das condições sócio-ecômicas e culturais das áreas, em futuros trabalhos.

Segundo Brasil (1984) é necessária a detecção das atividades econômicas das populações do entorno das Unidades de Conservação, para que o planejamento das atividades científicas levem essa variável em consideração, evitando-se o esfacelamento de alternativas de sobrevivência de populaçōes do entorno e em segundo lugar, para que haja melhor aproveitamento das áreas de pesquisa, evitando-se que as mesmas sejam destruídas por atividades prejudiciais, induzindo à manutenção das áreas limítrofes, pois qualquer trabalho em Unidade de Conservação que não leve em consideração essas variáveis corre 0 risco de ter comprometido sua própria finalidade.

\subsubsection{Instrumentos de Manejo e Gerenciamento das UC's}

\subsubsection{Plano de Ação Emergencial (PAE)}

O PAE, surgiu da necessidade de assegurar proteção às áreas, antes mesmo da elaboração dos Planos de Manejo. São efetuados tanto para as Unidades que ainda não têm Plano de Manejo, quanto para aquelas que têm Plano de Manejo a ser revisado (Workshop "Políticas de Unidades de Conservação", 1994).

Os planos são elaborados utilizando uma metodologia e linguagem única para todas as Unidades, consistindo de um planejamento participativo, com entidades públicas ou privadas e demais segmentos relacionados com a Unidade, o que conduz a ações mútuas e de co-gestão, prevendo a efetivação de medidas emergenciais no prazo máximo de 02 anos.

Somente os Parques Nacionais da Chapada dos Guimarães e do Pantanal Mato-grossense possuem PAEs realizados em 1994 e 1995, respectivamente, estando portanto nos seus prazos limites . O caráter de curto prazo, aliado a problemas administrativos, dificultam o cumprimento das metas estipuladas.

No Parque de Chapada a questão fundiária é um dos principais problemas identificados, sendo alvo de denúncia no próprio documento a grilagem de terras na região do Rio Claro, também elencando diversas ações emergenciais como 
a regularização fundiária e a desocupação das veredas e áreas frágeis. $O$ assunto tem causado inúmeras divergências, gerando uma ação junto à Procuradoria Regional de República desde 1996 de omissão e conivência com a grilagem de terras no interior do Parque Nacional.

\subsubsection{Plano de Manejo}

Salienta-se que das 78 unidades de Conservação de Uso Indireto no país, 20 delas possuem seu Plano de Manejo, e apenas em 02 delas os planos estão em vigência (Workshop "Políticas de Unidades de Conservação", 1994).

Horowitz (1992) avaliando o Plano de Manejo vigente do Parque Nacional de Brasilia, obteve $30 \%$ no seu índice de implementação, que foi considerado baixo, concluindo também que o planejamento e manejo do Parque não se pautou no seu Plano de Manejo, pois a maioria dos eventos levantados tiveram uma relação de mera casualidade com as atividades propostas. Para isso concorreram vários fatores: 1) o processo político-institucional, sócio-econômico e cultural da história dos Parques Nacionais brasileiros; 2) a falta de conhecimento dos objetivos do Parna nas proposições e execuções por parte de alguns dirigentes e funcionários, e de parcela significativa da sociedade e da maioria das instituições que se relacionam com a unidade; 3) o montante de recursos, quantidade e qualidade do pessoal envolvido; 4) a instabilidade institucional; 5) a lacuna entre a metodologia de planejamento e a administração do Plano de Manejo.

Nenhuma das Unidades mato-grossenses possui Plano de Manejo, sofrendo portanto, segundo Milano (1993) um manejo moderado, que é realizado quando a Unidade não conta com este instrumento. As ações ficam restritas a processos empíricos, experiências positivas que existem em outras Unidades (quando delas se tem conhecimento), ocorrendo justamente quando os funcionários realizam cursos específicos sobre Unidades de Conservação, tornado-se local adequado para troca de experiências e realizando a proteção do que é possivel dos recursos naturais e da infra-estrutura existentes na Unidade. 


\subsubsection{Plano Operativo Anual (POA)}

O Plano Operativo Anual (POA) é o planejamento das atividades a serem realizadas nas Unidades a cada ano e elaborado pela chefia das Unidades, onde se detalha as previsões orçamentárias e o período de execução de cada meta definida nos PAE's e Planos de Manejo, quando existem. É de importância fundamental para a gestão das Unidades que o POA esteja em concordância com as metas traçadas nos referidos planos.

No Estado do Mato Grosso as Unidades de Conservação contempladas pelo PNMA, são os Parques Nacionais, que segundo dados da Gerência do NUC/SUPES/MT (Núcleo de Unidades de Conservação) $80 \%$ da previsão orçamentária dos POA's são alcançadas.

As outras Unidades que são as Estações Ecológicas, se utilizam de recursos próprios que não são altos, para consumo (combustível, limpeza e higienização), gastos com pessoa jurídica (oficina, reforma do imóvel), pessoa física (limpeza das edificações), porém não estão sendo liberados recursos para obras e equipamentos.

Essas verbas são ainda utilizadas para diárias de deslocamento de pessoal para tratar de assuntos administrativos ou serviços de fiscalização ou mesmo capacitação do corpo de funcionários.

\subsection{Pessoal}

Segundo o documento Workshop "Políticas de Unidades de Conservação" (1994) os recursos humanos disponiveis para a gestão de Unidades de Conservação encontram-se num quadro crítico, tanto em termos quantitativos como qualitativos. A falta de qualificação técnica é agravada pela dificuldade de incorporação de pessoal imposta pelo sistema vigente na administração pública. Do total de 7.000 funcionários do IBAMA a nível de Brasil, apenas $6 \%$ trabalham em Unidades de Conservação, representando 437 funcionários, enquanto que o número ideal seria de 3.555 funcionários para atender a todas as Unidades de Conservação Federais. 
O Estado de Mato Grosso possui 146 funcionários lotados no IBAMA, dos quais 14 deles $(9,5 \%)$ trabalham nas Unidades de Conservação.

Foi identificada uma relação média de 23.541 ha de área "protegida" por funcionário lotado e que atuam diretamente nas Unidades de Conservação Federais. Comparando-se com a "melhor situação" que é a que ocorre na região Sudeste (1.759 ha por funcionário), esta conta com $56,3 \%$ do corpo de pessoal mínimo necessário (Milano, 1990).

O Estado de Mato Grosso possui a relação média de 30.000 hectares por funcionário, que práticamente não exprime a realidade, pois além da variaçăo da área de Unidade para Unidade, outros fatores como infra-estrutura (transporte, estrada, meios de comunicação, combustivel), capacitação técnica influem diretamente nessa relação.

São funcionários com uma relativa capacitação na área de Unidades de Conservação, porém nem todos eles fazem parte do quadro definitivo do Órgão, como no caso dos Chefes das Unidades de lquê-Juruena e Taiamã, não havendo garantias da permanência dos mesmos nas suas respectivas Unidades.

\section{Participação popular na criação das Unidades}

As Unidades de Conservação do Estado de Mato Grosso foram criadas mediante decisão do poder público, à exceção do Parque nacional de Chapada dos Guimarães e do Parque Estadual de Serra Azul. Unidades essas, criadas por iniciativa e intensa participação de representantes principalmente das ONG's AME e CELVA, respectivamente, entre outras. Outro exemplo dessa participação foi a aquisiçãode áreas pela ONG Ecotrópica, com o objetivo em tranformá-las em RPPN's. Sào participações ainda pequenas, porém efetivas, nesse campo da conservação no Estado.

\section{Congelamento na criação de novas Unidades}

O Brasil possui cerca de 3,5\% do seu território protegido em forma de Unidades de Conservação e está longe de acompanhar a tendência de preservação 
mundial que gira em torno de $5 \%$, enquanto na América $6,7 \%$ de seu território está protegido.

Dos biomas brasileiros somente a Amazônia possui uma representatividade razoável, sendo os cerrados pobremente representados (somente $1,6 \%$ do território), enquanto que a nível mundial a proteção das savans atinge cerca de $4,65 \%$ e também pouco representado se encontra o pantanal.

Outra questão preocupante é o risco de "congelamento", na criação de novas Unidades se não forem alteradas as condições hoje estabelecidas, pois desde 1992 nenhuma Unidade de Conservação Federal foi criada.

No Estado do Mato Grosso todas as Unidades de Conservação Federais (Parques Nacionais e Estações Ecológicas) foram criadas na década de 80 , e desde então nenhuma outra Unidade nova foi criada.

Mato Grosso com uma área em torno de $900.000 \mathrm{~km}^{2}$, possui apenas $0,46 \%$ de seu território ocupado por Unidades de Conservação Federais, equivalendo a aproximadamente 415.700 hectares.

Mesmo com a criação das Unidades Estaduais ainda não implantadas, esse percentual não se eleva muito devido a predominância de Unidades não muito grandes (observar tabela07)

A média aceitável de proteção de cada ecossistema gira em torno de $10 \%$, enquanto o cerrado, o segundo ecossistema em extensão territorial, não possui mais que $1,6 \%$ de áreas preservadas no país.

Segundo levantamentos da FUNATURA realizados em 1992 para atingir a meta de $30 \%$ de Unidadesde Conservação na Amazônia Legal, em Mato Grosso teriam que ser criadas 50 Unidades de Conservação, assim distribuídas: 12 Parques (01 de 68394 ha, 01 de 851.394 ha e 10 de 500.000 ha); 02 Reservas Biológicas (768.436 ha cada uma); 04 Estações Ecológicas (01 de 599.539 ha, 01 de 839.564 ha e 02 de 500.000 ha); 26 Florestas (02 de 651.400 ha e 24 de 500.000 ha); 04 Reservas Extrativistas ( 500.000 ha), e 02 Áreas de Proteção Ambiental (403.183 ha).

O Estado de Mato Grosso não possui mais terras públicas devido ao seu modelo de concessões de terras que ultrapassaram suas extensões territoriais, vindo prejudicar as apurações de terras públicas, que porventura existam, além de 
possuir o maior valor de terra nua médio (VTNm) da Amazônia Legal (FUNATURA, 1992).

Uma das saídas viáveis para esse problema, não descartando a criação de novas Unidades é a divulgação e incentivo à criação de RPPN's (Reserva Particular do Patrimônio Natural) em propriedades particulares, com atributos qualificáveis que justifiquem a sua implantação, tendo em vista seu importante papel em áreas fragmentadas. E também a criação das APA's, uma vez que não envolvem aquisição de terras e sim um ordenamento das atividades, nesse tipo de Unidade de Conservação.

A manutenção e ampliação do sistema, entretanto, se justifica por várias razões, entre elas 0 incentivo ao uso sustentado dos recursos naturais, proteção dos recursos genéticos da Nação, proteção das paisagens de belezas notáveis, locais de disponibilidade para pesquisa cientifica, educação ambiental, recreação ao ar livre e o desenvolvimento do ecoturismo.

Fica evidente a questão de prioridades, pois o governo federal alega inexistência de recursos e a sociedade como um todo ainda não está sendo capaz de equacionar os benefícios da implantação dessas áreas protegidas.

Indiscutivelmente parte dos problemas existentes são gerados pela falta de consciência e de conhecimento sobre as questões ambientais, além, obviamente de vontade política por parte do governo, que está preocupado com outros tipos de investimento mais" rentáveis".

Outro fator importante é a dependência de programas financiadores especificos como é o caso do PRODEAGRO no Estado do Mato Grosso que pressionou e impôs o tema Unidades de Conservação, sendo preocupante a manutenção desse programa após o término de sua vigência, ficando clara a sua importância tanto para as Unidades Federais quanto para as Estaduais. 


\section{CONSIDERAÇÕES FINAIS}

As Unidades de Conservação mato-grossenses, foram e continuam sendo implantadas em terras que não se prestaram a utilização da fronteira agropecuária, ficando restritas às áreas remanescentes dos três ecossistemas (floresta amazônica, cerrado e o pantanal).

A representação dos ecossistemas na forma de Unidades de Conservação Federais é muito reduzida $(0,5 \%)$ em relação à área do Estado (901.420 $\left.\mathrm{km}^{2}\right)$ e a sua grande diversidade biológica, ficando muito longe da recomendação ao nível mundial que é de $10 \%$.

É de suma importância a implantação de Reservas Particulares do Patrimônio Natural (RPPN) e APA's (Área de Proteção Ambiental) como uma das saídas viáveis para a manutenção da biodiversidade do Estado, uma vez que o mesmo não mais dispõe de áreas públicas.

Importante também é divulgar amplamente e esclarecer a população e os dirigentes políticos da importância em particular da criação e manutenção das Unidades de Conservação no Estado de Mato Grosso, detentor de grande biodiversidade. Bem como a união de esforços dos dois órgãos gestores IBAMA e FEMA e um maior entrosamento nesse campo de atuação

As discussões sobre a Hidrovia Paraguai-Paraná não têm envolvido e deveriam envolver as Unidades de Conservação implantadas no pantanal como a estação Ecológica Taiamã (Cáceres), Parque Nacional do Pantanal Matogrossense (Poconé) e as RPPN's lindeiras ao Parque Nacional, uma vez que estão localizadas no trecho mais polêmico dos $600 \mathrm{~km}$ de Cáceres a Corumbá, onde estão previstas as maiores modificações no ecossistema pantaneiro.

Faz-se necessária a revogação do Decreto do Presidente da República de 02/10/96, revogando a criação da Estação Ecológica Iquê-Juruena, para que o 
Estado não perca sua maior Unidade de Conservação Federal na amazônia matogrossense.

A existência de Unidades de Conservação por si só, não garante a conservação dos recursos naturais, sendo necessário proceder a criação de novas Unidades e consolidar as Unidades já existentes, promovendo uma regularização ágil, garantindo uma maior fiscalização, através dos investimentos qualitativos e quantitavos no corpo de funcionários e dando a essas Unidades a importáncia merecida no processo desenvolvimento do Estado de Mato grosso.

Para tanto serão necessárias medidas efetivas às politicas públicas em todos os níveis, bem como a implementação de um maior envolvimento da sociedade civil nesse processo.

Sugere-se também o incentivo à pesquisa, que privilegiem levantamentos básicos de fauna e flora para a identificação de áreas a serem protegidas, cujos critérios de seleção se baseiam nos endemismos, biodiversidade e espécies ameaçadas. Esse incentivo deve ser estendido à estudos nas Unidades de Conservação já implantadas pois todos elas possuem campos férteis de pesquisas. 


\section{REFERÊNCIAS BIBLIOGRÁFICAS}

BALLOU, J. ; FOOSE, T. LACY, R. Introduction. In: POPULATION \& HABITAT VIABILITY ANALISIS WORKSHOP, 1992.

BARCELOS, M., ; BUSATTO, I.L. As terras indígenas. In: OPERAÇÃO ANCHIETA. Dossiê índios em Mato Grosso. Cuiabá: OPAN; CIMIMT, 1987. p.7-10.

BAZZAZ, F. A. Characteristics of populations in relation to disturbance in natural and man-modified ecosystems. In: MOONEY, H.; GODRON, M. (Ed) Disturbance and ecosystems. Springer-Verlag, 1983. p.275-279.

BRASIL. Comissão Interministerial para Preparação da Conferência das Nações Unidas sobre o Meio Ambiente e Desenvolvimento. 0 desafio do desenvolvimento sustentável. Brasília, 1991. 203 p.

BRASIL. Conselho Nacional do Meio Ambiente. Resolução Conama 1984 a 1990. 3. ed. Brasília: SEMAN /IBAMA, 1991. $231 \mathrm{p}$.

BRASIL. Instituto Brasileiro do Meio Ambiente e dos Recursos Naturais Renováveis. Sistema Nacional de Unidades de Conservação: aspectos conceituais e legais. Brasília, 1989. $59 \mathrm{p}$.

BRASIL. Instituto Brasileiro do Meio Ambiente e dos Recursos Naturais Renováveis. Unidades de Conservação do Brasil. Brasília, 1989. 192 p.

BRASIL. Instituto Brasileiro do Meio Ambiente e dos Recursos Naturais Renováveis. Edição Documental. Cuiabá, 1990. 32 p. 
BRASIL. Instituto Brasileiro do Meio Ambiente e dos Recursos Naturais Renováveis. Parque Nacional do Pantanal Matogrossense: plano de ação emergencial. Cuiabá, 1994. 81 p.

BRASIL. Instituto Brasileiro do Meio Ambiente e dos Recursos Naturais Renováveis. Parque Nacional da Chapada dos Guimarães: plano de ação emergencial. Cuiabá, 1995. 123 p.

BRASIL. Ministério da Minas e Energia. Projeto RADAMBRASIL:.folha SC.21 Juruena: geologia, geomorfologia, pedologia, vegetação e uso potencial da terra. Rio de Janeiro, 1980. 458 p.

BRASIL. Ministério da Minas e Energia. Projeto RADAMBRASIL: folhas SD Cuiabá: geologia, geomorfologia, pedologia, vegetação e uso potencial da terra. Rio de Janeiro, 1982. 544 p.

BROWN. K. Proposta de Criação de uma reserva Biológica na Chapada dos Guimarães. Revista Brasil Florestal, 1970.

BURKEY, T.V. Extinction in nature reserves: the effect of fragmentation and the importance of migration between reserves fragments. Oikos, v.55, p.75-81, 1989.

CARVALHO, N.O. Hidrologia da Bacia do Alto Paraguai. In: simpósio sobre recursos naturais e sócio econômicos do pantanal, Corumbá, 1986. Anais. p.43-49.

CASTRO, M.I.; GALLETI, L. Histórico dos usos da biodiversidade em Mato Grosso. In: CASTRO, C. (Org.) Diagnóstico florestal de Mato Grosso. Brasilia: FUNATURA/ITTO, 1994. 173 p. 
COLE, B.J. Colonizing abilities, island size, and the number of species-area relationships. The American Naturalist, v. 117, p.629-683, 1981.

COMISSÃO DE DEFESA DO CONSUMIDOR, MEIO AMBIENTE E MINORIAS. Projeto de lei $n^{\circ} 2892$, de 1992. http:// www.bdt.org.br.

CUTLER, A. Nested faunas and extinction in fragmented habitats. Conservation Biology, v. 5, n. 4, p.496-505, 1991.

DASMANN, R. F. Enviromental conservation. 5. ed. New York : John Wiley, 1983. $486 \mathrm{p}$.

DIAMOND, J.M. Implications of island biogeography for ecossystem conservation. In: SIEGFREID, W. R.; DAVIE, B. R. Conservation of ecossystems: theory and practice south african national scientific programmes. 1982. p. 46-60.

DIAMOND, J.M. The Island Dilema: lessons of modern biogeographic studies for design of natural reserves. Biological Conservation, v.7, p.24-46, 1975.

DIAS, B.F.S. Conservação da natureza no Cerrado Brasileiro. In: PINTO, M. N. (Org.) Cerrado: caracterização, ocupação e perspectivas. Brasília: UnB, 1993. p.606-663.

DIEGUES, A.C. O mito moderno da natureza intocada. Săo Paulo: USP, Núcleo de Apoio à Pesquisa sobre Populações Humanas e Áreas Úmidas Brasileiras, 1994. $163 \mathrm{p}$.

DUARTE, A.C. (Org.) Geografia do Brasil: Região Centro Oeste. Rio de Janeiro: IBGE, 1988. O Centro Oeste na organização regional do Brasil. p.243-258. 
EMPRESA MATO-GROSSENSE DE PESQUISA, ASSISTÊNCIA E EXTENSÃO RURAL. Estudo da realidade Municipal. Barra do Bugres, 1996a. 1v.

EMPRESA MATO-GROSSENSE DE PESQUISA, ASSISTÊNCIA E EXTENSÃO RURAL. Estudo da realidade Municipal. Cáceres, 1996b. $1 \mathrm{v}$.

EMPRESA MATO-GROSSENSE DE PESQUISA, ASSISTÊNCIA E EXTENSÃO RURAL. Estudo da realidade Municipal. Chapada dos Guimarães, 1996c 1v.

EMPRESA MATO-GROSSENSE DE PESQUISA, ASSISTÊNCIA E EXTENSÃO RURAL. Estudo da realidade Municipal. Cuiabá, 1996d 1v.

EMPRESA MATO-GROSSENSE DE PESQUISA, ASSISTÊNCIA E EXTENSÃO RURAL. Estudo da realidade Municipal. Juina, 1996e 1v.

EMPRESA MATO-GROSSENSE DE PESQUISA, ASSISTENNCIA E EXTENSÃO RURAL. Estudo da realidade Municipal. Poconé, 1996f $1 \mathrm{v}$.

EMPRESA MATO-GROSSENSE DE PESQUISA, ASSISTÊNCIA E EXTENSÃO RURAL. Estudo da realidade Municipal. Porto Estrela, 1996g 1v.

FAHRIG, L.; MERRIAM, G. Conservation of fragmented populations. Conservation Biology, v.8, n.1, p. 50-59, 1994.

FEARNSIDE, P.M. Spatial concentration of deforestation in the Brazilian Amazon. Ambio, v. 5, n.2, p. 74-81, 1986.

FONSECA, G.A.A. ; RYLANDS, A.B. ; COSTA, M.R. ; MACHADO, R.B. \& LEITE, Y.L.R. Livro vermelho dos mamíferos ameaçados de extinção. Belo Horizonte: Fundação Biodiversitas, 1994. 479 p. 
FOOSE, T. Small population biology \& population and habitat viability assessment. POPULATION \& HABITAT VIABILITY ANALYSIS WORKSHOP, 1992.

FUNDAÇÃO JÚLIO CAMPOS. Municípios de Mato Grosso: Juína. Várzea Grande, 1993. 32p.

FUNDAÇÃO PRÓ-NATUREZA. Sistema Nacional de Unidades de Conservação SNUC. Brasília: 1989. 78 p.

FUNDAÇÃO PRÓ-NATUREZA. Custo de implantação de Unidades de Conservação na Amazônia Legal. Brasilia: 1992. 80 p.

GAME, M. Best shape for nature reserves. Nature, v. 287 , n. 5783, p. $630-631$, 1980.

GILPIN, M.E.; SOULÉ, M.E. Minimum viable populations: process of species extinction. In: SOULÉ, M.E. (Ed.) Conservation biology: the science of scarcity and diversity. Sunderland: Sinauer, 1986. p.19-34.

GRUMBINE, R.E. What is ecosystem management? Conservation Biology, v.8, n.1, p.27 - 38, 1994.

GUARIM, V.L.S. Dados preliminares das condições físico-químicas de alguns corpos dágua da llha de Taiamã. In: Universidade Federal do Mato Grosso. Projeto Estações Ecológicas de Mato Grosso-Estação Ecológica de Taiamã Pantanal Matogrossense. Cuiabá, 1983. p.5-18. 
GUARIM NETO, G. Contribuição preliminar para a flora da Estação Ecológica de Taiamã (Dicotiledôneas). In: Universidade Federal do Mato Grosso. Projeto Estações Ecológicas de Mato Grosso-Estação Ecológica de Taiamã Pantanal Matogrossense). Cuiabá, 1983. p.42-50.

HARRIS, L. The fragmented forest: Isiand biogeography theory and preservation of biotic diversity.Chicago:University of Chicago Press, 1984. $221 \mathrm{p}$.

HIGA, N.T. ; SILVA, C. J. Caracterização da área indígena Enawene-Nawe. In: OPERAÇÃO ANCHIETA. Estudo das potencialidades e do manejo dos recursos naturais na área indígena Enawene-Nawe: relatório. Cuiabá, 1995. p.6-18.

HOROWITZ, C. Plano de manejo do Parque Nacional de Brasília: avaliação da metodologia de planejamento adotada, execução e resultados alcançados no decénio 1979-1989. Brasília, 1993. 202p. Dissertação (Mestrado) Universidade de Brasília.

JANZEN, D.H. No park is an island: increase in interference from outside as park size decreases. Oikos, v. 41, p. $402-410,1983$.

JÄRVINEN, O. Conservation of endagered plant populations: single large or several small reserves?, Oikos, v.38, p. $301-307,1982$.

LAURENCE, W.F. Edge effects in tropical forest fragments: application of a model for the design of nature reserves. Biological Conservation, v. $57, p$. $205-219,1991$. 
LOVEJOY, T.E.; BIERRGAARD JR., R.O.; RYLANDS, A.B. et al. Edge and others effectes of isolation on Amazon forest fragments. In: SOULE, M.E. (Ed) Conservation biology: the science of scarcity and diversity. Sunderland: Sinauer, 1986. p.257-285.

MAURER, B.A. The relationship between distribuition and abundance in apatchy enviroment. Oikos, v.58, n. 2, p.181-189, 1990.

MILANO, M.S. Conceitos básicos e princípios gerais de planejamento, manejo e administração. In: Curso sobre manejo de áreas naturais protegidas. Curitiba, 1993. p.1-60.

MWALYOSI, R.B.B. Ecological evaluation for wildlife corridors and buffer zones for Lake Manyara national Park, Tanzania, and its immediate environment. Biological Conservation, v. 57, p.171-186, 1991.

NOGUEIRA NETO, P. Estações Ecológicas. São Paulo: Empresa das Artes, 1991. $103 p$.

PÁDUA, J. As origens da ecologia política no Brasil. In: PÁDUA, J. (Org.) Ecologia e política no Brasil: espaço e tempo. Rio de Janeiro, UPERJ, 1987.

PINTO, W.D. Legislação federal de meio ambiente. Brasília: IBAMA, 1996. $3 v$.

PROJETO DE DESENVOLVIMENTO AGROAMBIENTAL DE MATO GROSSO. Documento sintetizado do "Aide Memoire". Cuiabá, 1992. 36 p.

QUINTÃO, A. Evolução do conceito de parques nacionais e sua relação com o processo de desenvolvimento. Brasil Fiorestal, n. 54, p.13-27, 1983. 
ROBINSON, G.R.; HOLT, R.D.; GAINES, M.S. et al. Diverse and contrasting effects of habitat fragmentation. Science, v. 257, n. 5069, p.524 -526, 1992.

SEILERT, V.F. Áreas Indígenas em Mato Grosso: quadro situacional das intrusões e das ações públicas. Projeto de Cooperação Técnica ao Prodeagro - PNUD/BRA/94/006. Consultoria para Plano e fiscalização e Vigilância nas Áreas Indígenas de Mato Grosso $1^{a}$ etapa, abril. Cuiabá, 1995. 58p (mimeo).

SHAFER, C.L. Values and shortcomings of small reserves. Bioscience, v. 45, n.2, p.80-88, 1995.

SHAFFER, M. Mininum population sizes for species conservation: Bioscience, v.31, n. 2 , p.131-134, 1981.

SILVA, C. J. Levantamento de Macrófitas Aquáticas na Estação Ecológica de Taiamã. In: Universidade federal do Mato Grosso. Projeto Estações Ecológicas de Mato Grosso-Estação Ecológica de Taiamã: Pantanal Matogrossense. Cuiabá, 1983. p.19-41.

SILVA, C.J.; SILVA, J.A.F. No ritmo das águas do Pantanal. São Paulo:USP, Núcleo de Apoio à Pesquisa sobre Populações Humanas e Áreas Úmidas Brasileiras, 1995. $210 \mathrm{p}$.

SILVA, J.A.F. Política indigenista oficial e ocupação de Mato Grosso 1970-1986. In: OPERAÇÃO ANCHIETA. Dossiê índios em Mato Grosso. Cuiabá: OPAN; CIMI/MT, 1987. p.23-44.

SILVA, J.F.; SILVA, C.J. Estratégias de sobrevivência de comunidades tradicionais no Pantanal Matogrossense: estudo de caso. São Paulo: USP, Núcleo de Apoio à Pesquisa sobre Populações Humanas e Áreas Úmidas Brasileiras, 1992.67p. 
SILVA, J. M. C. ; ONIKI, Y. Lista preliminar da avifauna da Estação Ecológica Serra das Araras, Mato Grosso, Brasil. Boletim. do Museu. Paraense. Emilio Goeldi, vol.4, n.2, p. 123-143, 1988.

SILVA, L. L. Ecologia: manejo de áreas silvestres. Santa Maria: MMA, FNMA,FATEC, 1996. 352 p.

SILVA, P.P.C.; FERREIRA, J.C.V. Breve história de Mato Grosso e seus municípios. Cuiabá, 1994. 253 p.

SIMBERLOFF, D. Big advantages of small refuges. Natural History, v. 91, p.6-14, 1982.

SIMBERLOFF, D.; ABELE, L.G. Refuge design and island biogeography: efect of fragmentation. The American Naturalist, n. 120, p.41-50, 1982.

SIMBERLOFF, D.; COX, J. Consequences and costs of conservation corridors. Conservation Biology, v. 1, n. 1, p.63-71, 1987.

SIQUEIRA, E.M.; COSTA, L.A.; CARVALHO, C.M.C. O processo histórico de Mato Grosso. Cuiabá: UFMT, 1990. 151 p.

SONODA, F. Resgate das relações entre as comunidades circunvizinhas à Estação Ecológica da Serra das Araras-MT, como estratégia de uma proposta de educação ambiental. Mato Grosso, 1991 . 52p. Monografia (Especialização) Universidade Federal do Mato Grosso.

STRÜSSMANN, C. Composição e aspectos ecológicos da fauna de répteis da Estação Ecológica de Serra das Araras MT, Brasil. Cuiabá: SEMA/MDU, 1988. 56 p. (Relatório final de atividades). 
TABANEZ, A.A.J. Ecologia e manejo de ecounidades em um fragmento florestal na região de Piracicaba, SP. Piracicaba, 1995. 85p. Dissertação (Mestrado) Escola Superior de Agricultura Luiz de Queiroz, Universidade de São Paulo.

TERBORGH, J. Preservation of natural diversity: the problem of extinction-prone species. Bioscience, v. 24, p. 715 - 722, 1974.

TOLEDO, M.C.B. Avifauna em duas reservas fragmentadas de Mata Atlântica, na Serra da Mantiqueira. Piracicaba, 1993. 112p. Dissertação (Mestrado) Escola Superior de Agricultura Luiz de Queiroz, Universidade de São Paulo.

UFMT. Propostas referentes ao Plano de Zoneamento e Manejo da Estação Ecológica Serra das Araras-Disciplina Conservação dos recursos naturais, 1989 (Relatório).

VIANA, V.M. Biologia e manejo de fragmentos de florestas naturais. In: CONGRESSO FLORESTAL BRASILEIRO, 6. p. 113-116. Anais. Campos de Jordão, 1990.

VIANA, V.M.; TABANEZ, A.J.A.; MARTINEZ, J. L.A. Restauração e manejo de fragmentos florestais. In: CONGRESSO NACIONAL DE ESSENNCIAS NATIVAS, 2. Anais. São Paulo, 1992. p. 400-406.

WATTS, D. Principles of biogeography. New York :McGraw-Hill, 1971. 401p.

WHITMORE, T. C. An introduction to tropical florest. Clarendo: Oxford Press, $1991.226 \mathrm{p}$.

WILSON, E. O ; BASSERT. W.H. A primer of population biology. 1971. 193 p. 
WORKSHOP POLÍTICAS DE UNIDADES DE CONSERVAÇÃO, Brasilia, 1994. Documentos. Brasília Ministério do Meio Ambiente dos Recursos Hídricos e Amazônia Legal, 1994. 1v. 